\title{
ECOLOGICAL RESTORATION OF WAIRIO WETLAND, LAKE WAIRARAPA: THE RESPONSE OF NATIVE WETLAND VEGETATION TO EUTROPHICATION AND REVEGETATION MANAGEMENT STRATEGIES
}

BY

APRILLE KATE GILLON

A thesis submitted for the partial fulfilment for the degree of Master of Science in Ecological Restoration

Victoria University of Wellington 


\begin{abstract}
Wetlands are highly productive ecosystems that support abundant native fauna and flora and provide many essential functions and services, for example water purification, erosion stabilisation, floodwater storage, groundwater recharge, peat accumulation and biogeochemical cycling. Despite the vast benefits they provide, worldwide loss and degradation of wetlands still continues, mainly due to agriculture, urban development, population growth and exploitation. Wetland disturbance can cause altered hydrological regimes, invasive species introduction, soil and water eutrophication, habitat fragmentation, and reductions in native fauna and flora leading to an overall reduced functionality. Ecological restoration is an active practice commonly undertaken in degraded wetlands to re-establish ecosystem functioning, and most commonly includes revegetation, reconstruction of hydrology, weed control, pest management, and native species reintroductions.
\end{abstract}

Wairio Wetland located on the eastern shores of Lake Wairarapa forms a part of WairarapaMoana, the largest wetland complex in the lower North Island of New Zealand. Wairio Wetland was historically an abundant kahikatea swamp forest, with a diverse range of waterfowl, waders and freshwater fish. However, the wetland was adversely affected by draining from the Lower Wairarapa Valley Development Scheme (LWVDS) during the 1960's and 1970's, the construction of Parera Road, and invasion of willow tree seeds planted in the Wairarapa Valley for erosion control. Draining of the wetland, division from nearby lagoons and ponds, nitrogen and phosphorus build-up in waterways and exotic weed invasion all contributed to the poor state of the wetland. In 2005, Ducks Unlimited (DU) in conjunction with the Department of Conservation (DOC) and various members of the local community formed the Wairio Wetland Restoration Committee, with aims to manage and restore the wetland to its natural pre-settlement state. Restoration activities undertaken at the site that have included native tree planting, earthworks, weed control, pest management and fencing sections of the site to exclude cattle, have been met with mixed success over the years. 
This thesis reports on two studies undertaken at Wairio Wetland with aims to inform future restoration efforts at the site. The committee have proposed to divert nutrient rich water through Wairio Wetland to increase filtration and improve the water quality of Lake Wairarapa. However, the effects of nutrient loading on established plant communities at the site are unknown. Therefore the first study, conducted between December 2012 and May 2013 in Stage 2 of the wetland, examined the effects of fertiliser addition on biomass, structure and diversity of a wetland plant community. Different levels of phosphate and nitrate fertiliser were applied to 50 plots $\left(4 \mathrm{~m}^{2}\right)$ of vegetation at the site with percent cover, and average height of respective species recorded every four to five weeks. Results showed that the addition of phosphorous and/or nitrogen had neither a positive nor negative effect on the plant community at Wairio with no significant changes in the 15 species recorded at the site. These results contrast other studies that have reported increases in biomass, reductions in biodiversity and common/introduced species outcompeting rare/native species. The short duration of the experiment and summer drought conditions may have obscured the above-ground visual responses of the plant community to nutrient addition; therefore further continuation of this experiment is advised.

Previous low success rates of native tree plantings at Wairio Wetland have significantly hindered revegetation efforts at the site. Therefore the second study, conducted between July 2011 and January 2014 in Stage 3 of the wetland, further investigates the effects of various management treatments on establishment of native woody vegetation. The study involved monitoring 2,368 planted trees of eight native wetland tree/shrub species, including; Cordyline australis, Dacrycarpus dacridioides, Olearia virgata, Podocarpus totara, Coprosma robusta, Coprosma propinqua, Leptospermum scoparium, and Pittosporum tenuifolium. The trees were subjected to various planting treatments including the excavation or retention of topsoil, presence or absence of weedmats and presence or absence of nurse trees with spacing of $0.75 \mathrm{~m}$ or $1.5 \mathrm{~m}$. Survival and growth of each tree was measured every six months over the 30 month experimental period. Results showed that interspecific competition and hydrology appeared to be the main processes influencing the establishment of native plantings at Wairio Wetland, with plant mortality greatest in the first year after planting. Waterlogging, in particular, was detrimental to establishment of all 
species at the site except $D$. dacridioides. Topsoil excavation and the planting of nurse trees at $1.5 \mathrm{~m}$ spacing was the most effective management treatment combination promoting survival of plantings at Wairio. However, the success of management treatments varied greatly between species at the site and had different impacts on plant growth. Topsoil excavation was beneficial to survival of $D$. dacridioides and $C$. robusta but detrimental to growth of C. australis, O. virgata, C. propinqua, P. tenuifolium and L. scoparium. The concurrent planting of nurse trees with focal trees was beneficial to the survival of $D$. dacridioides, growth of $P$. totara, and survival and growth of $C$. australis. The planting of nurse trees further apart at $1.5 \mathrm{~m}$ compared to $0.75 \mathrm{~m}$ had a positive effect on the survival of C. propinqua and P. tenuifolium, and survival and growth of L. scoparium. Weedmats were beneficial to survival of $O$. virgata and growth of $L$. scoparium but detrimental to growth of $D$. dacridioides. These management treatments can be used in future revegetation efforts at Wairio Wetland, and potentially in other wetland restoration projects throughout New Zealand. 


\section{Acknowledgements}

I would sincerely like to thank my supervisor Dr Stephen Hartley who has provided me with invaluable knowledge of statistical analysis, advice and support throughout my thesis writing. Funding for this project was provided by Jim and Marilyn Law from the Wairio Wetland Restoration Committee and The Wellington Botanical Society of which I am sincerely grateful. Continued support for this project was encouraged by the Wairio Wetland Restoration Committee with associated members from Ducks Unlimited, Greater Wellington Regional Council, The Department of Conservation and the Fish and Game Council, who have provided me with vital information about the site and its flora and fauna.

I would like to thank my family for their encouragement, financial and mental support throughout my thesis. My wonderful field assistants Zak, Patrick, Patrika, Susanne, Tapuwa, Cheng, Kristina, and Stephen have given up their time to help me at some stage in collecting data from the site in all sorts of conditions of which I am immensely thankful. I would like to thank Bridget Johnson for support in continuing the planting experiment she set up in 2011 of which one of my studies continues. I would also like to thank Victoria University's Bug club for their helpful advice and knowledge provided throughout my Masters. 


\section{Table of Contents}

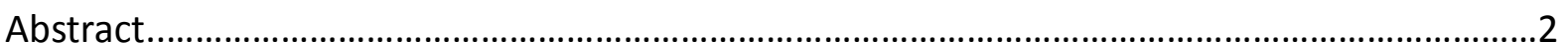

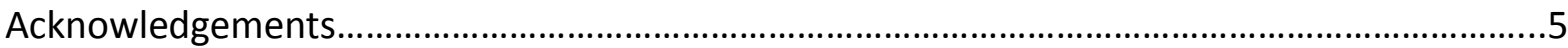

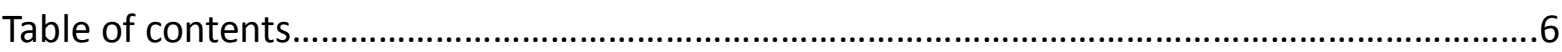

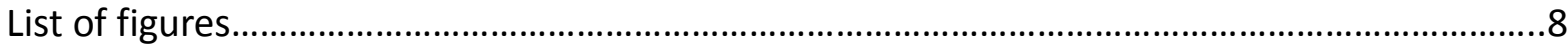

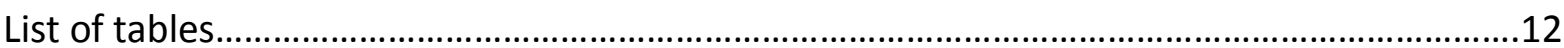

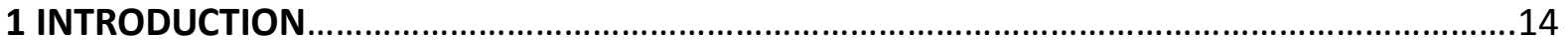

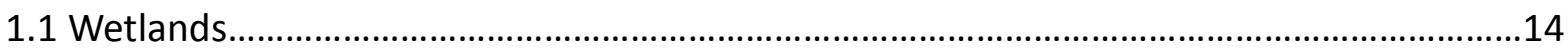

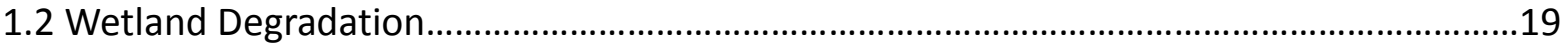

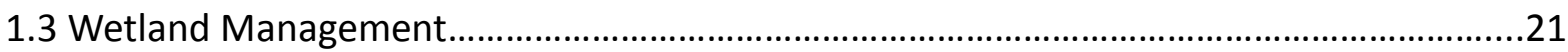

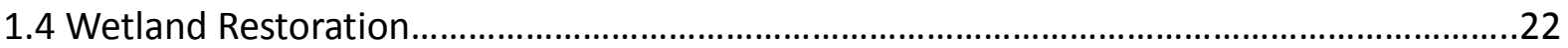

1.5 Wairio Wetland

1.6 Research Aims

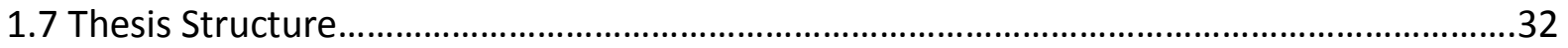

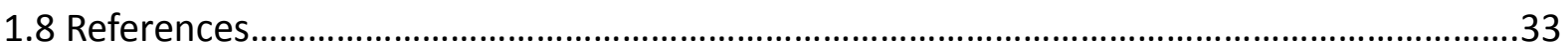

2 THE EFFECTS OF EUTROPHICATION ON STRUCTURE, DIVERSITY AND BIOMASS OF A

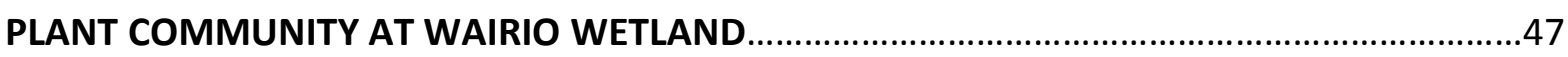

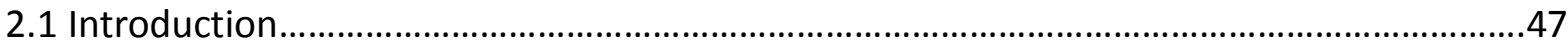

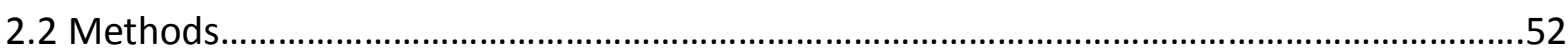

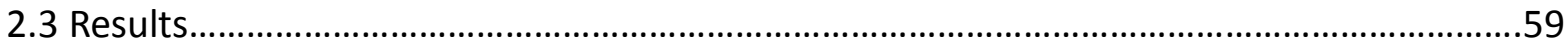

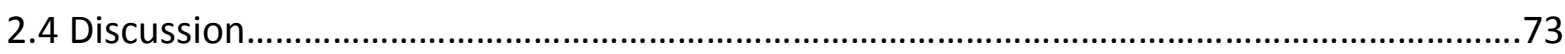

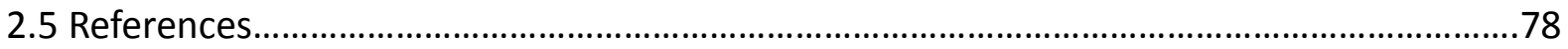

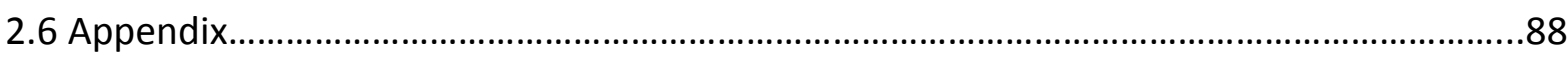

3 THE EFFECTS OF DIFFERENT REVEGETATION MANAGEMENT TREATMENTS ON THE ESTABLISHMENT OF NATIVE WOODY VEGETATION AT WAIRIO WETLAND............................93

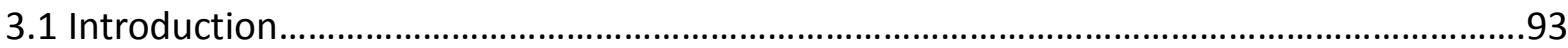

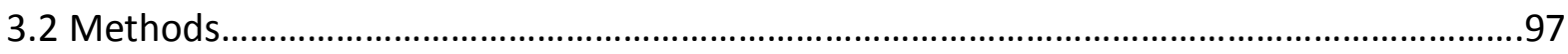

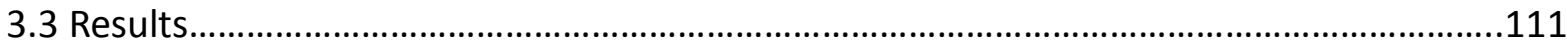

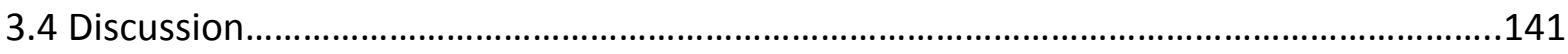

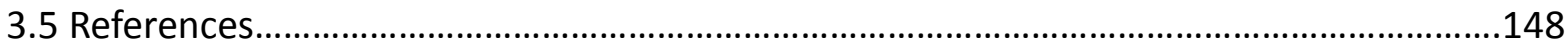


3.6 Appendix. .157

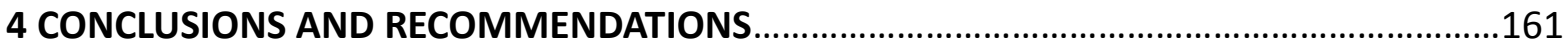

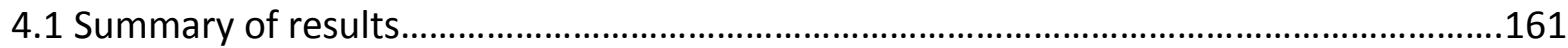

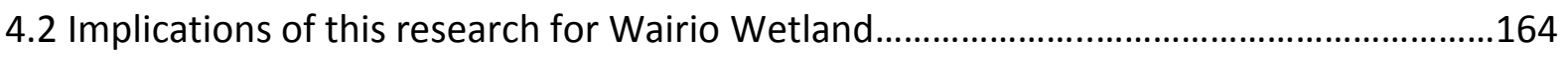

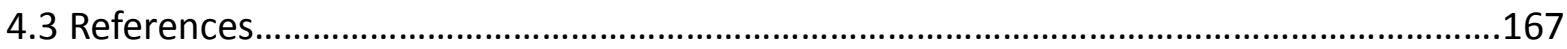

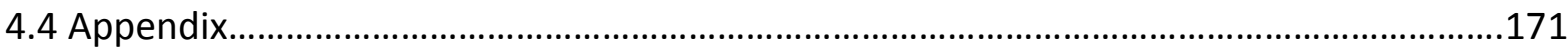




\section{List of figures}

Figure 1 Diagram showing the seasonal phases of an ephemeral wetland.

Figure 2 Diagram showing the zonation of vegetation in an ephemeral wetland.

Figure 3 Map of the lower North Island of New Zealand, showing the location of Wairio Wetland.

Figure 4 Aerial picture of Wairio Wetland, showing the location of Stage 1, 2 and 3.

Figure 5 Map of Stage 2, Wairio Wetland showing the approximate location of the five experimental treatment blocks.

Figure 6 Map showing selected sites of soil sample collection from blocks one to five in Stage 2.

Figure 7 Weekly recordings of average rainfall $(\mathrm{mm})$ and average sunshine (hours) from 1 July 2012 to 31 July 2013 from a local weather station.

Figure 8 Soil $\mathrm{pH}$ and moisture (\% water) for plots at the site in response to the addition of (a) Phosphorous (b) Nitrogen.

Figure 9 (a) Soil phosphorous (ug/ml) concentration and (b) Soil nitrogen (\% w/w) concentration of selected plots ( $n=5$, one per block) in response to fertiliser addition.

Figure 10 (a) Soil carbon (\%w/w) and nitrogen (\%w/w) levels in selected plots at the site in response to fertilizer treatments. (b) Soil carbon-nitrogen (\% w/w) and phosphorous (ug/ml) levels in selected plots at the site in response to fertilizer treatments.

Figure 11 Change in log percent cover of plant species recorded at each data collection time (December - May) for the control treatment (no fertiliser added).

Figure 12 Change in log percent cover of plant species recorded at each data collection time (December - May) for the (a) high phosphorous treatment and (b) high nitrogen treatment.

Figure 13 Principle co-ordinate analysis plot of the change in species abundance in the 50 plots from December to May overlaid with a fitted surface of contours of nutrient application for (a) Phosphorous, (b) Nitrogen. 
Figure 14 PCoA plot of the relative change in abundance of species in plots at the site from December to May in response to (a) phosphorous, and (b) nitrogen addition.

Figure 15 Scatterplot of change in log (biomass) of Isolepis prolifera from December to May in response to phosphorous and nitrogen fertiliser concentrations in plots.

Figure 16 Aerial picture of Wairio Wetland and its respective management stages.

Figure 17 Stage 3 of Wairio Wetland showing respective block layout. Inset shows layout of plots within each block.

Figure 18 There are eight large blocks (30m x 40m) each containing 96 focal and 192 nurse trees (288 in total).

Figure 19 There are two medium blocks $(30 \mathrm{~m} \times 30 \mathrm{~m})$ each containing 64 focal and 96 nurse trees (288 in total).

Figure 20 Relative survival of focal and nurse species over the 30 month period since planting.

Figure 21 Pie graphs showing proportion of Cordyline australis surviving in blocks at Wairio Wetland after 30 months.

Figure 22 Pie graphs showing proportion of Dacrycarpus dacridioides surviving in blocks at Wairio Wetland after 30 months.

Figure 23 Pie graphs showing proportion of Podocarpus totara surviving in blocks at Wairio Wetland after 30 months.

Figure 24 Pie graphs showing proportion of Olearia virgata surviving in blocks at Wairio Wetland after 30 months.

Figure 25 Pie graphs showing proportion of Coprosma propinqua (CP) and Pittosporum tenuifolium (PT) surviving in blocks at Wairio Wetland after 30 months.

Figure 26 Pie graphs showing proportion of Coprosma robusta (CR) and Leptospermum scoparium (LS) surviving in blocks at Wairio Wetland after 30 months.

Figure 27 Proportion of focal and nurse species populations alive over time in response to the topsoil treatment (excavated, retained). 
Figure 28 Proportion of focal and nurse species populations alive over time in response to the presence or absence of weedmats.

Figure 29 Proportion of focal species alive over time in response to the presence or absence of nurse trees.

Figure 30 Proportion of nurse species alive over time in response to spacing treatment $0.75 \mathrm{~m}, 1.5 \mathrm{~m})$.

Figure 31 Proportion of Coprosma robusta alive in response to the combination of percent water $($ low $=0-20 \%$, medium $=21-40 \%$, high $=41-60 \%)$ averaged over the study period and topsoil removal (excavated/retained).

Figure 32 Proportion of Olearia virgata alive in response to the combination of weedmat (present/absent) and topsoil removal (excavated/retained).

Figure 33 Proportion of Olearia virgata alive in response to the combination of weedmat (present/absent) and nurse presence (nurse/no nurse).

Figure 34 Proportion of Olearia virgata alive in response to the combination of percent water $($ low $=0-20 \%$, medium $=21-40 \%$, high $=41-60 \%$, very high $=61+\%$ water $)$ averaged over the study period and weedmat (weedmat/no weedmat).

Figure 35 Proportion of Dacrycarpus dacridioides alive in response to the combination of water level (low $=0-20 \%$, medium $=21-40 \%$, high $=41-60 \%$, very high $=61+\%$ water $)$ averaged over the study period and nurse presence (nurse/no nurse).

Figure 36 Growth $(\mathrm{cm})$ of each species over the 30-month period.

Figure 37 Boxplots of plant height distributions of each species 30 months after planting.

Figure 38 Plant height distributions of species 30 months after planting in reponse to topsoil removal (excavated/retained).

Figure 39 Scatterplots of plant heights at different water levels (average \% cover) at the site for the species Dacrycarpus dacridioides, Podocarpus totara, and Pittosporum tenuifolium after 30-months of monitoring.

Figure $\mathbf{4 0}$ Study species planted at Wairio Wetland. 
Figure 41 The author at Wairio Wetland, Stage 2, recording plant composition in quadrats.

Figure 42 Wairio Wetland, Stage 2, Block 3. Block and plot boundaries outlined with bamboo sticks and builders wire.

Figure 43 Wairio Wetland, Stage 2, percent cover of vegetation in Block 3, Plot 1D.

Figure 44 Wairio Wetland, Stage 2, Height profile of vegetation in Block 3, Plot 1B.

Figure 45 The author at Wairio Wetland, Stage 3, recording the survival of trees in a block with abundant weeds.

Figure 46 The author at Wairio Wetland, Stage 3, measuring the height of trees in the waterlogged blocks at the site.

Figure 47 Stage 3 at Wairio Wetland, Block 9 with newly planted saplings in June 2011.

Figure 48 Stage 3 at Wairio Wetland, Block 9 in December 2011.

Figure 49 Stage 3 at Wairio Wetland, Block 9 in September 2012.

Figure 50 Stage 3 at Wairio Wetland, Block 9 in February 2014. 


\section{List of tables}

Table 1 Wetland functions and their respective ecosystem services and values to humans.

Table 2 Anthropogenic forces and activities contributing to the degradation of wetlands.

Table 3 Nine ecological attributes of restored ecosystems.

Table 4 Ecological restoration project guidelines.

Table 5 Within-block replication of fertiliser treatments.

Table 6 Species abundance (average percent cover) and number of plots occupied in December and May within 50 plots in Stage 2, Wairio Wetland.

Table 7 Linear mixed effects model of the relationship between the change in individual plant species biomass (\% cover $\mathrm{x}$ average height) over the experimental period and the addition of phosphorous and nitrogen.

Table 8 Linear mixed effects model showing the effect of fertiliser on changes in the Shannon Wiener diversity index of the plant community from December to May within plots at the site.

Table 9 Relative GPS co-ordinates for the centre of each of the five treatment blocks in stage 2 of the Wairio Wetland.

Table 10 Fertiliser treatment concentrations for each plot (1A-2E) in each block.

Table 11 List of days visited Stage 2 for experimentation and activities undertaken.

Table 12 Linear mixed effects model showing the effect of fertiliser on $\mathrm{pH}$ and moisture levels within plots at the site.

Table 13 List of species identified in plots of the nutrient enrichment experiment.

Table 14 Five treatments with corresponding treatment options

Table 15 Number of native trees planted in 2011

Table 16 Probable causes of plant death.

Table 17 Mortality rates of focal species per six month interval, measured over the 30month period since planting. 
Table 18 Mortality rates of nurse species per six month interval, measured over the 30month period since planting.

Table 19 Number of deaths attributed to a probable cause for each species based on field observations.

Table 20 Linear mixed effects model of focal tree 30-month survival in response to various management treatments and site conditions.

Table 21 Linear mixed effects model of nurse tree 30-month survival in response to various management treatments and site conditions.

Table 22 Cost of each tree species (NZD) per management treatment combination.

Table 23 Survival (Proportion alive) of each species per management treatment combination, 30 months after planting.

Table 24 Cost-benefit analysis (cost per surviving tree in NZD) of each species per management treatment combination, 30 months after planting.

Table 25 Linear mixed effects model of focal tree 30-month growth in response to various management treatments and site conditions

Table 26 Linear mixed effects model of nurse tree 30-month growth in response to various management treatments and site conditions.

Table 27 Plot treatments and nurse species combinations in blocks at the site.

Table 28 Focal and nurse species survival (proportion alive) within blocks at the site, 30 months after planting.

Table 29 Cost (per tree) of various management treatment options.

Table 30 Summary of management techniques proposed to promote plant establishment for each species at Wairio Wetland. 


\section{Chapter 1}

\section{GENERAL INTRODUCTION}

\subsection{Wetlands}

\subsubsection{What are wetlands?}

Wetlands form at the boundaries of both terrestrial and aquatic systems (Cowardin et al. 1979). Under the New Zealand Resource Management Act 1991, wetlands include "permanently or intermittently wet areas, shallow water, and land water margins that support a natural ecosystem of plants and animals that are adapted to wet conditions". Hydrology and geomorphology are the main forces shaping wetlands promoting distinct types depending on their position in the landscape and the water source (van der Valk 2006). There are several freshwater wetland types which have various functional and physical aspects; these include marshes, swamps, fens, bogs and shallow water wetlands (Johnson \& Gerbeaux 2004; van Roon 2012). Ephemeral wetlands are a subset of marshes and are essentially surface land depressions that experience large periodic fluctuations in water levels (Johnson \& Rogers 2003; Ulrich 2005; Zedler 1987) (Figure 1).

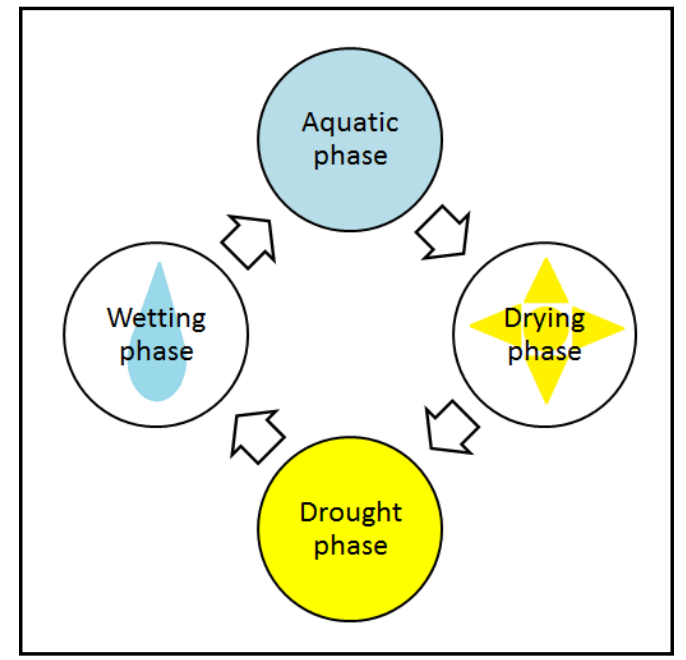

Figure 1 Diagram showing the seasonal phases of an ephemeral wetland (adapted from Zedler 1987). 


\subsubsection{What are the functions of a wetland?}

Wetlands are one of the most productive ecosystems in the world (Mitsch \& Gosselink 2007). Wetland services have been valued at US\$14,785 per ha per year (Costanza et al. 1997), for the array of functions, services and values they can provide (Table 1). Wetlands were once regarded as 'wastelands' (Mitsch \& Gosselink 2007) and were drained and filled to create farmland and urban developments, with their full array of functions only recently realised.

Table 1 Wetland functions and their respective ecosystem services and values to humans.

\begin{tabular}{|c|c|c|}
\hline Functions & Services & Values \\
\hline Water purification & $\begin{array}{l}\text { Trap sediments; sequester } \\
\text { nutrients/pollutants }\end{array}$ & $\begin{array}{l}\text { Improve water quality, } \\
\text { waste water treatment }\end{array}$ \\
\hline Groundwater recharge & Replenish groundwater & Freshwater supply \\
\hline Flood water storage & Reduce local flood levels & $\begin{array}{l}\text { Reduce risk of property } \\
\text { damage/livestock loss }\end{array}$ \\
\hline Erosion stabilisation & Halt erosion rates & $\begin{array}{l}\text { Reduce risk of property/land } \\
\text { damage }\end{array}$ \\
\hline Peat accumulation & Carbon sequestration & $\begin{array}{l}\text { Reduce greenhouse gas } \\
\text { emissions }\end{array}$ \\
\hline Biogeochemical cycling & Pollutant removal & $\begin{array}{l}\text { Improve water quality/ } \\
\text { maintenance of fisheries }\end{array}$ \\
\hline Wildlife habitat & $\begin{array}{l}\text { Shelter, refuge, breeding } \\
\text { ground and food supply for } \\
\text { wildlife; food for humans }\end{array}$ & $\begin{array}{l}\text { Commercial and recreational } \\
\text { hunting, fishing and bird } \\
\text { watching; education }\end{array}$ \\
\hline
\end{tabular}

Wetlands have an important role in water purification with the potential to aid waste water treatment (Greenway 2005), reduce soil and water eutrophication (Mitsch et al. 2001), remove excess nutrients from agricultural runoff (Gottschall et al. 2007) and remove pollutants or heavy metals from industrial or chemical runoff (Cheng et al. 2002). Vegetation in wetlands can effectively trap surplus sediments and uptake excess nutrients, pollutants and heavy metals in the water and soils (Gottschall et al. 2007; Johnston 1991; Reilly et al. 1999). Wetlands can play a role in recharging below-ground aquifers that can supply towns 
with clean drinking water (van der Kamp \& Hayashi 1998) or restocking farm irrigation groundwater stores (Acharya \& Barbier 2000). Surplus rainwater and surface waters that is not stored by plants and soils in the wetland or escapes via surface flows or evapotranspiration can filter into groundwater stores (Roth 2009).

Wetlands can reduce local flood levels helping to avoid property damage or stock loss to local farms and houses with significant economic benefits (Hey \& Philippi 1995; Ming et al. 2007). Wetland soils and vegetation can store large amounts of storm water runoff during high rainfall events acting as a reservoir and protecting nearby land. Wetlands can also prevent erosion via the stabilisation of soils (Larson et al. 1989). The roots of wetland macrophytes can help anchor soils, to stop erosion in extreme weather events such as flooding or storm surges (Brix 1997). This function has the potential to avoid property and land damage in extreme events.

Wetlands have the ability to accumulate decomposed vegetation and store their nutrients in a peat layer (Kayranli et al. 2010). Atmospheric carbon sequestered by wetland vegetation and degraded by soil microbes can remain stored in soil peat layers leading to a reduction in greenhouse gas emissions and climate regulation (Badiou et al. 2011; Middleton 1999; Zedler 2000). Armentano \& Menges (1990) suggested temperate wetlands can absorb up to $83 \times 10^{6}$ tons/yr of carbon and thus act as a crucial carbon sink. Wetlands also play a crucial role in biogeochemical cycling of nutrients (Cherry 2012). Pollutants and excess nutrients in the wetland can be absorbed by the plants and soils promoting improved water quality and associated maintenance of recreational fisheries (Rekolainen et al. 2006; Smith 2003).

Wetlands provide important wildlife habitat for various aquatic and terrestrial species (Woodward \& Wui 2001). Wetlands are characterised by a rich diversity of species strongly controlled by the dynamic water regimes with plants and animals adapted to certain levels, depths and duration of water inundation (Gibbs 1995; Williams 1996). Wetlands can provide food, shelter, freshwater and refuge for these species (Larson et al. 1989). Wetlands and surrounding areas are commonly used as a permanent or seasonal breeding ground and nursery for birds (Naugle et al. 2001), amphibians and reptiles (Semlitsch \& Bodie 2003), and 
marine life. Ephemeral wetlands, in particular, can support a largely predator-free fauna due to the short-time of standing water and dynamic conditions deterring invasive species (Zedler 2000). Wetland species commonly have a localised distribution or small isolated populations which can be highly vulnerable to extinction if the wetland is destroyed or damaged (Gibbs 2000). The abundant plant and animal species found in wetlands can provide commercial and recreational benefits such as fishing, hunting, food gathering, bird watching, and medicinal plants.

\subsubsection{Wetland hydrology}

Hydrology determines water levels, water quantities and flows in a wetland. Hydrology in a wetland can be controlled by surface water, precipitation, groundwater levels, evapotranspiration rates and changes in water levels of nearby water sources e.g. lakes, ponds or rivers (Mitsch \& Gosselink 2007; Roth 2009). Wetland hydrology can vary greatly between seasons from changing rainfall levels and sunshine intensity. Hydrology can control soil pH levels, redox status and nutrient cycling (Bridgham \& Richardson 1993). Hydrology can strongly influence plant community composition dependent on the duration and depth of flooding, soil moisture levels, ground-water level and water quality (Casanova \& Brock 2000; Sorrell et al. 2004; Thompson et al. 2012).

\subsubsection{Wetland vegetation}

In New Zealand, wetlands are characterised by a high diversity and abundance of native and non-native vegetation (Flinn et al. 2008; Zedler \& Kircher 2004). Wetlands exhibit strong plant zonation where different distinct communities of species are found in zones from the permanently dry land (never submerged) down to the open water (always submerged) (Cherry 2012; Clarkson \& Peters 2010; Johnson \& Rogers 2003) (Figure 2). Climatic changes ultimately determine the pattern of plant zonation in a given wetland plant community by influencing the water regime (Casanova \& Brock 2000). Forests or scrubland dominate the highlands and are rarely submerged underwater. Rush lands are the next vegetation zone and can withstand occasional flooding (Johnson \& Rogers 2003). Sward vegetation consists of sedges and grasses $(<10 \mathrm{~cm}$ tall) and is common in most wetlands for its ability to 
withstand periodic flooding and draining (Johnson \& Rogers 2003; Rodwell 1998). Turf vegetation $(<3 \mathrm{~cm}$ tall) is either submerged or wet most of the year. The aquatic vegetative zone is submerged year round providing a stable environment for aquatic plants.

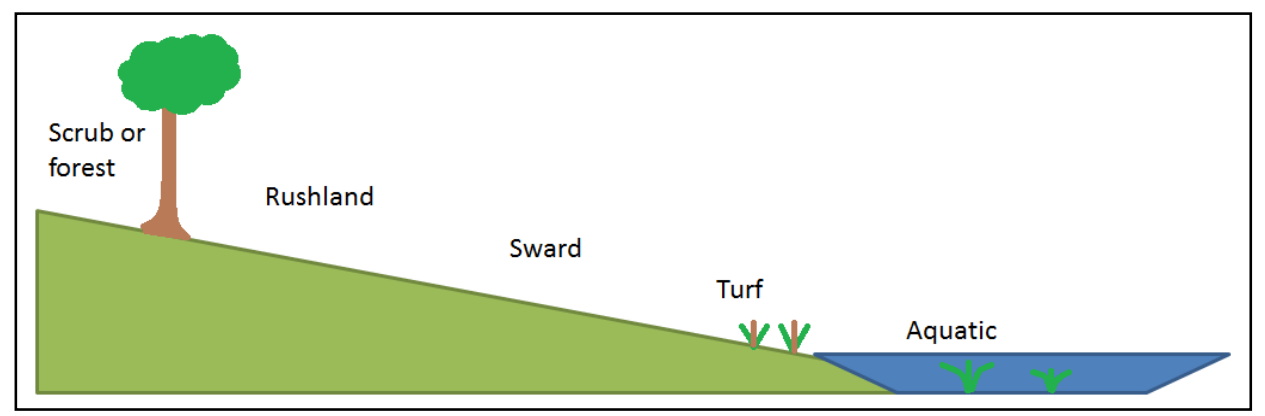

Figure 2 Diagram showing the zonation of vegetation in an ephemeral wetland. Distinct vegetation types are shown (adapted from Johnson \& Rogers 2003).

Wetland plants have to withstand harsh dynamic environmental conditions (Price et al. 2010; Warwick \& Brock 2003). The duration and intensity of a flooding or drought event can ultimately influence the composition of a wetland plant community (Casanova \& Brock 2000; Price et al. 2010; Warwick \& Brock 2003). Flooding can result in anoxic soil conditions limiting the supply of oxygen and carbon dioxide to the plant and ultimately influencing aerobic respiration, photosynthesis and cellular functions (Jackson 2006). Plants not adapted to the anoxic conditions may experience stunted or no growth, or death (Pezeshki 2001). Droughts reduce soil moisture levels and if water stores are depleted can also result in stunted growth or the death of plants. Seed banks are a crucial adaptation of wetland plant species to survive where the water regime is dynamic (James et al. 2007). Plant species produce a large seed bank when water is abundant that remains dormant in the soil during drought conditions until water re-inundates and seeds can germinate (James et al. 2007; Warwick \& Brock 2003). 


\subsection{Wetland degradation}

\subsubsection{International situation}

The vast majority of wetlands are experiencing worldwide loss and degradation at an unprecedented rate, with approximately $50 \%$ of global wetlands lost since the 1900 s, reaching 70-90\% in highly developed regions (Finlayson et al. 1999; Ramsar Convention on Wetlands 2005). A decade ago wetlands in the USA were lost at a rate of 600 ha per day (Hollis \& Bedding 1994). The conversion of wetlands to non-wetland areas and the impairment of wetland functions by anthropogenic forces have predominantly been driven by a rise in agriculture, urban development, population growth and exploitation of ecosystem services (van Asselen et al. 2013). Wetland hydrological disturbance can include drainage, deposition, damming, water diversion and groundwater drawdown. Wetland habitat destruction can include fragmentation, burning and logging of native vegetation, introduction of exotic species and eutrophication (Roth 2009) (Table 2).

Table 2 Anthropogenic forces and activities contributing to the degradation of wetlands.

\begin{tabular}{ll}
\hline Anthropogenic forces & Activities \\
\hline Agriculture/urban & Drainage \\
development & Sediment deposition \\
& Habitat fragmentation \\
& Excess nutrient loading \\
& Damming \\
Freshwater resource & Water diversion \\
& Groundwater drawdown \\
Timber resource & Logging of native vegetation \\
Crop production & Introduction of exotic species \\
\hline
\end{tabular}

Degraded wetlands can be characterised by an inundation of invasive weeds, eutrophic water and soils, low abundance of native fauna and flora, and altered hydrology (Davis and Froend 1999). Wetland degradation can subsequently lead to loss of the ecosystem services, biodiversity and economic benefits wetlands provide. 


\subsubsection{New Zealand situation}

New Zealand has a long history of wetland degradation with approximately $90 \%$ of New Zealand freshwater wetlands destroyed since Maori and European settlement (Ausseil et al. 2011; Cromarty \& Scott 1996; McGlone 2009). Wetland drainage for agricultural use was the most common form of destruction to wetlands in New Zealand (van Roon 2012). Wetland destruction for farming was promoted by the government up until the 1980's due to the large economic benefits productive agricultural land could provide (Gerbeaux 2002). Up until the late 1900's legislation governing the wise-use of wetlands was lacking and wetlands were facing increased degradation. A study of 7000 wetlands still intact in New Zealand were found to have lost over $60 \%$ of their native biodiversity, with the majority less than 10 ha in size and highly fragmented (Ausseil et al. 2001). Wetlands in highly populated urban areas in New Zealand (e.g. Auckland, Wellington) have experienced the greatest levels of degradation. In comparison, isolated, rural areas (e.g. Fiordland, Westland) have wetlands that remain in pre-settlement condition with little or no degradation (Ausseil et al. 2001).

\subsubsection{Eutrophication}

In this decade, the main source of degradation of wetlands is eutrophication which is the increasing accumulation of excess nutrients in an environment (Bennett et al. 2001; Nixon 1995). The most common cause of soil and water eutrophication is agricultural runoff, such as fertiliser, effluent from paddocks, and wastewater from milking sheds, entering waterways and leading to wetland pollution (Boers et al. 2006). Nitrates and phosphates are the most common minerals found from these sources and can lead to an increased nutrient load entering wetlands (Carpenter et al. 1998; Smith et al. 1999). Water eutrophication is associated with hypoxia, the depletion of oxygen levels in the water and soils, which can make it hard for marine life and plants to respire (Carpenter 2005; Smith 2003). Phytoplankton respond positively to an increase in water nutrients and can create toxic blooms which are poisonous to animals and humans (Rekolainen et al. 2006; Smith 2003). The vegetation and fauna can also change in response to the eutrophic conditions which could lead to reduced ecosystem functioning as a whole for the wetland (Engelhardt \& Ritchie 2001). It is common for aggressive or invasive plant species to favour eutrophic conditions which can result in non-native dominated vegetation (Boers et al. 2006). 


\subsection{Wetland Management}

The Convention on Wetlands of International Importance, known as the Ramsar Convention, is an intergovernmental treaty that was formed in 1971 in Iran with various countries worldwide joining to sustainably protect and halt degradation of wetlands (Ramsar Convention Secretariat 2013). Parties in the convention have commitments to integrate wetland management into their national environmental policies, to actively sustain wetlands, and to encourage other countries to join the convention. As of the $15^{\text {th }}$ of January 2014, 168 countries had joined the convention with 2,171 Ramsar sites totalling 207.3 million hectares of wetland classified as internationally significant (Ramsar Convention Secretariat 2014). New Zealand was the $13^{\text {th }}$ country to join the Ramsar Convention on the $13^{\text {th }}$ December 1976 and has six Ramsar sites to date (van Roon 2012). New Zealand's current Ramsar sites are the Awarua wetlands, Farewell Spit, Manawatu Estuary, Whangamarino wetland, Kopuatai Peat Dome and Firth of Thames. These Ramsar sites were chosen because they are representative of a specific wetland type, are at a near-natural state, support biological or cultural diversity and provide ecosystem services (Ramsar Convention Secretariat 2013).

In 1986 the New Zealand government established the New Zealand Wetlands Management Policy that has objectives to preserve and protect current wetlands, maintain a wetland inventory, and increase public awareness on the importance of wetlands (Gerbeaux 2002). New Zealand wetlands are foremost governed and managed by the New Zealand Biodiversity Strategy and Resource Management Act 1991 (van Roon 2012). The Department of Conservation is primarily in charge of managing wetlands on government land under the New Zealand Wetland Management Policy 1986. Local councils are responsible for ensuring landowners responsibly manage private wetlands. The National Wetland Trust is a non-profit organisation formed in 1999 with aims to increase public awareness of the value of wetlands, increase understanding of wetland functions and processes, and ensure that the government, councils, and landowners commit to ensuring wetland protection and restoration (National Wetland Trust of New Zealand 1999). 


\subsection{Wetland restoration}

\subsubsection{Ecological restoration}

Ecological restoration is an important practice undertaken to actively assist and accelerate the recovery of an ecosystem that has been degraded, damaged, or destroyed (Society for Ecological Restoration 2004). Restoration projects aim to achieve biodiversity conservation, ensure sustainability of important ecosystem functions, and maintain ecosystem services (Aronson \& van Andel 2006; Greipsson 2011; Harris \& van Diggelen 2006). Ecological restoration practice is based on the academic discipline of restoration ecology which applies ecological theory and ideas to the regeneration of degraded ecosystems (Bell et al. 1997; Clewell \& Reiger 1997; Vaughn et al. 2010). Restoration science encompasses many different ecological concepts and theories such as succession, facilitation, disturbance, and landscape ecology (Aronson \& van Andel 2006; Harris \& van Diggelen 2006; Society for Ecological Restoration 2004). The Society for Ecological Restoration (2004) have proposed nine attributes linked to species composition, landscape integration and sustainability that are characteristic of fully restored ecosystems (Table 3).

Table 3 Nine ecological attributes of restored ecosystems (adapted from Clewell \& Aronson 2007; Society for Ecological Restoration 2004).

\section{Species Composition}

1. Assemblage of species historic to site present

2. Greatest extent of native species present

3. Functional species groups present

4. Sustain reproductive species

Landscape

5. Integration of restored site into wider landscape

6. Threats from surrounding landscapes reduced/removed

Sustainability

7. Resilient to sources of stress and disturbance

8. Self-sustaining

9. Ecosystem fully functional 
Restoration is usually undertaken by community groups, local councils or individuals and can include activities such as revegetation, reconstruction of hydrology, weed control, pest management, land clearing and native species reintroductions (Cairns Jr 2000; Clewell \& Aronson 2007; Middleton 1999; Vaughn et al. 2010). The success of restoration projects can be linked to having a concise plan of action with clear goals, measurable objectives, realistic management actions and an adaptive monitoring protocol suited to the particular site requirements (Clewell \& Aronson 2007; Ehrenfield 2000; Hobbs \& Norton 1996). Restoration of degraded ecosystems is a time consuming, costly process that requires a long-term commitment by those parties involved. A set of guidelines have been developed by Hobbs \& Norton (1996) and the Society for Ecological Restoration (2004) to aid practitioners and volunteers undertaking restoration (Table 4).

Table 4 Ecological restoration project guidelines (adapted from Hobbs \& Norton 1996; Society for Ecological Restoration 2004).
1. Prioritise site and project choice
2. Identify agent of decline
3. Devise methods to reverse degradation
4. Designate a reference system as a target
5. Set a long-term project vision/target
6. Develop realistic goals and quantifiable objectives
7. Set performance standards to assess achievements
8. Implement a long-term monitoring programme
9. Evaluate project success, undertake adaptive management

\subsubsection{Revegetation}

Revegetation is one of the main goals in ecological restoration of degraded wetlands (Follstad Shah et al. 2007). It ideally involves the planting or seeding of wetlands with native eco-sourced plant species to accelerate the establishment of a native plant community (Porteous 1993). Eco-sourcing of plants from local nurseries is essential to maintain and conserve local tree populations distinct to geographical areas. Clarkson \& Peters 2010 considers five essential requirements are crucial to ensure long-term survival of restoration plantings. These requirements are suitable species selection, weed removal, pest/stock 
control, site maintenance, and monitoring (Clarkson \& Peters 2010). Successful native plant establishment can help restore historic community assemblages at the wetland, aid biodiversity conservation, restore natural wetland functioning such as water filtration, flood storage and erosion stabilisation, and help maintain ecosystem services (Aronson \& van Andel 2006; Griepsson 2011; Harris \& van Diggelen 2006). The success of revegetation efforts can vary greatly between projects due to environmental site conditions, planting procedures adopted and the selection of plants.

\subsubsection{Restoring wetland hydrology}

Hydrology influences the functioning, type, sustainability, and size of a wetland so is crucial to consider in restoration activities (Carter 1996). Wetland hydrology is complex and restoration should ideally be undertaken at a landscape wide scale (Bedford 1996), however most activities occur at a localised wetland specific scale by communities with limited funds and time. Water quality, quantity and flow are the main hydrological aspects altered during restoration. Activities can include reconnection of local waterways to the wetland, damming of the wetland to store water, lowering ground levels to raise water levels or water diversion (Campbell 2010). Restoration of degraded hydrological regimes is usually the first activity undertaken with a moderate response time in contrast to other activities (Bruland et al. 2003).

\subsubsection{Removal of invasive weeds}

Invasive weed species are characteristically fast growing, highly competitive and resilient to low resource levels in degraded systems (Stinson et al. 2006). Control of invasive pastoral weeds costs the New Zealand economy \$1.2 billion annually (Bourdôt 2012). Invasive weed species are common in degraded wetlands and can prove problematic to restoration efforts, competing with native plantings for limited nutrients in the environment (Connell 1983; Goldberg 1990; Tilman 1997), altering soil microbial communities and nutrient cycling (Batten et al. 2006; Ehrenfield 2003), modifying wetland hydrology (Charles \& Dukes 2007) and changing plant community composition. Weed control methods vary in success and can include grazing management, manual removal, chemical control such as herbicide use, biological control, physical control or plant protection such as the use of weedmats or tree guards (Bodmin 2010; Porteous 1993). 


\subsection{Wairio Wetland}

\subsubsection{Location}

Wairio Wetland is located next to Lake Wairarapa, Kahutara, New Zealand (Figure 3). Wairio Wetland is a 132.3 ha stretch of land bordering Lake Wairarapa to the east, Oporua Spillway to the north, Paerera Road to the west and farmland to the south. The Wetland forms a significant part of the 7,800 ha Wairarapa-Moana complex, the largest wetland complex in the lower North Island of New Zealand (Forsyth \& Dixon 2004).

\subsubsection{History of degradation}

Wairio Wetland has had a long history of degradation that first started during Maori settlement approximately 700 years ago where kahikatea swamp forest lining the lake was cut down or burnt to create villages for easy access to the lake (McFadgen 2003). Degradation continued when the Europeans settled in the area in the 1840's and exotic plants were introduced into the grassland for pastoral farming (Heslop 1995; Mclntyre 2002). The Lower Wairarapa Valley Development Scheme (LWVSC) was introduced in 1964 to alleviate flooding risk to the area (Airey et al. 2000). This 20 year scheme involved draining of the lake, the creation of barrage gates south of Alsops Bay, diversion of the Ruamahunga River, and the creation of the Oporua spillway and stop banks around the lake to control lake water levels (Airey et al. 2000; Armstrong 2004; Mclntyre 2002). The hydrology of the area was severely altered by this scheme, with Wairio Wetland being subject to intense draining (Airey et al. 2000; Armstrong 2004; Greater Wellington Regional Council 2009). Parera Road was also built to the east of the wetland for easy access to the lake, however this meant Wairio was cut off from nearby Matthews Lagoon and Boggy Pond's water supply and the ground levels were also altered. Additionally, willow trees were planted in the Wairarapa Valley for erosion control, but have unfortunately caused water diversion, and promoted increased sedimentation of the lake (Greater Wellington Regional Council 2012). Cattle farming at Wairio and the wider area have also promoted declining water quality levels with excess nitrogen and phosphorus entering waterways (Greater Wellington Regional Council 2012). 


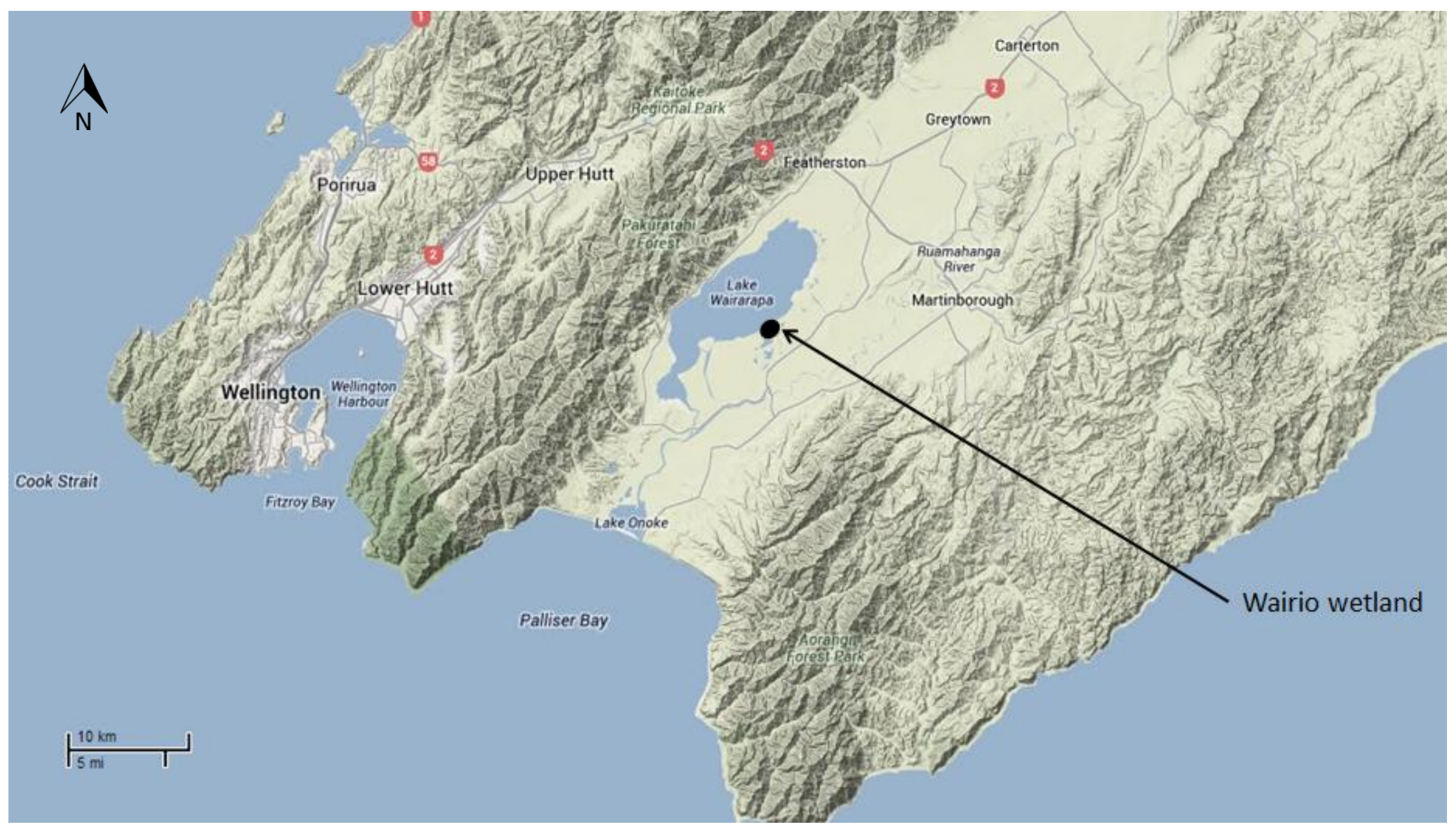

Figure 3 Map of the lower North Island of New Zealand, showing the location of Wairio Wetland (adapted from Google maps 2014). 


\subsubsection{Climate and weather}

Wairio Wetland is situated in the southern Wairarapa plains ecological district that is characterised by warm, mild summers and cold winters with few frosts (Garrick et al. 2007). Sudden temperature changes are common with average daily temperatures of $7-17^{\circ} \mathrm{C}$ and a night-time temperature of $1-3{ }^{\circ} \mathrm{C}$, however summer temperatures can often reach above 23 ${ }^{\circ} \mathrm{C}$ (Beadel et al. 2000). Rainfall is also variable with between $1,326 \mathrm{~mm}$ and $1,540 \mathrm{~mm}$ of rainfall annually (Beadel et al. 2000). Highest rainfall is from September to November meaning the flooding risk is elevated (Greater Wellington Regional Council 2011). The lake and surroundings are highly exposed to the predominant strong North-Westerly winds year round which can reach up to 11-14 knots (Beadel et al. 2000). The windy conditions can generate a strong seiche effect in Lake Wairarapa, elevating water levels up to one metre in some areas on the eastern shoreline (including Wairio) (Garrick et al. 2007).

\subsubsection{Geomorphology and soils}

During the mid-Holocene period, approximately 6,000 years ago, an alluvial plain was formed by geological forces (Beadel et al. 2000). This alluvial plain created the lowland ecological plain, Lake Wairarapa and its surrounding landscape (Beadel et al. 2000). Lake Wairarapa, Lake Onoke and associated lagoons and wetlands formed a large ocean embayment with characteristic shorelines of sandy dunes and large mudflats (Beadel et al. 2000). Extensive flooding was common at the time with strong ocean currents and winds dictating fluctuating water levels. Changing river courses and sedimentation during flooding helped form the many lagoons and wetlands present today surrounding Lake Wairarapa such as Boggy Pond, Matthews Lagoon and Wairio Wetland (Airey et al. 2000).

The soils of the Wairarapa plains are derived from alluvium deposits transported by the rivers (Heine 1975). The eastern side of the lake encompassing Wairio Wetland has highly fertile kairanga and manawatu soils (Garrick et al. 2007). Kairanga soils are on slow-draining flood plains, with sandy loams to clays, and brown topsoil to grey subsoil (Heine 1975). In contrast, manawatu soils form sandy dunes and are on free-draining flood plains with slow surface drainage, crumbly deep brown to yellow brown sandy loams and silt loams (McEwen 1987). 


\subsubsection{Freshwater ecosystem and hydrology}

Wairio Wetland is an ephemeral wetland that experiences flooding in the winter months and dries out during the summer months. Wairio Wetland is fed by water from the lake, groundwater and rain water. The water quantity in the wetland itself is low with large natural and constructed ephemeral ponds making up most of the current wetland state. The Wairio Wetland is linked to the wider Wairarapa-Moana catchment that includes Lake Wairarapa, Lake Onoke and its surrounding wetlands and lagoons. The Tauherenikau River, Ruamahunga drainage and other northern tributaries feed water into Lake Wairarapa (Greater Wellington Regional Council 2012). The water then flows through Alsops Bay and exits into the ocean via Lake Onoke which is controlled by a barrage. The barrage gates are used to control lake levels and are moderated by the council with agreement from farmers and residents to decrease the flood risk to the area and supply excess water for farmers during the dry summer months (Beadel et al. 2000). Excessive dairy farming in the area has led to large amounts of nutrients entering the waterways causing phosphorus and nitrogen build-up in the lake. Lake Wairarapa has a shallow lake bed with a maximum depth of $2.5 \mathrm{~m}$ that has enhanced sediment build-up (Garrick et al. 2007). The lake has been classified as supertrophic, but its status is improving, due to both high nutrients and increased sediment deposition causing extremely poor water quality (Perrie 2005). Supertrophic lakes are associated with poor water clarity, common algal blooms in the summer months, and overall poor fish and freshwater invertebrate abundance (Greater Wellington Regional Council 2012).

\subsubsection{Flora}

Before human settlement to the Lake Wairarapa area it is believed Wairio Wetland was a dense kahikatea-dominant swamp forest with remnant trees still at the site today (Beadel 2000; Hill 1963). Wairio also is believed to have had native wetland vegetation including characteristic cabbage tree (Cordyline australis), raupo (Typha orientalis), harakeke (Phormium tenax), toetoe (Cortaderia spp), and various reeds, rushes and sedges (Beadel 2000). Since Maori settlement commenced in the late 1840's the fauna drastically changed with burning and cutting of forest trees to create villages surrounding the lake (Hill 1963). European settlement also promoted sheep farming where large areas of forest, native herbs 
and shrubs were destroyed to create pastureland for stock (Hill 1963). Weed species established in quick succession and exotic pasture grasses were grown.

A total of 84 plant species were recorded by Ogle and colleagues in a 1990 plant survey encompassing Wairio, Matthews lagoon, Boggy pond and the Eastern shoreline of Lake Wairarapa between the Oporua spillway and South end of Wairio. Of those 84 species recorded, there are four species that are currently threatened with one species (Amphibromus fluitans) currently listed as nationally endangered (Garrick et al. 2007). There is high zonation of plant species at Wairio linked to the variable water levels at the site promoting a large variation of species. Sedges, rushes and dicotyledonous herbs are the dominant vegetation type at Wairio with introduced species common. Common nuisance weed species at the site include blackberry, gorse, tall fescue, lupin and alders (Law 2012). Weed species are currently controlled in some areas of the site where planting has commenced and consists of bouts of spot spraying around planted trees and release spraying every three months (Law 2012). Weed species in areas of the site where restoration activities have not yet taken place is kept at manageable levels by cattle browse. Crack willow that lines the lake edge is also aerial sprayed by the Greater Wellington Regional Council (hereafter referred to as GWRC). Restoration planting at Wairio first commenced in 2006 with sedges, flaxes and trees being planted in Stage 1 (Law 2012).

\subsubsection{Fauna}

Wairio Wetland is dominated by abundant birdlife. Wairio and the eastern shorelines are important habitat for breeding, roosting and feeding of waterfowl and waders. 102 bird species have been recorded at Wairio and the surrounding eastern Lake Wairarapa area by various parties over the last 30 years (Arthur 2012; Moore et al. 1999). This includes 80 indigenous/native species and 22 introduced/naturalised species. In recent years common birds spotted at Wairio and the nearby Oporua Spillway include the pectoral sandpiper, black-billed gull, black-backed gull, bar-tailed godwit, black swan, paradise shelduck, and banded dotterel (Robertson \& Heather 1999). Migratory species such as godwits make regulatory visits to the area for breeding, and resting. There are also six nationally endangered/critically endangered bird species in the Lake Wairarapa area; these include the 
black-fronted tern, black-billed gull, black stilt, Australasian bittern, grey duck and white heron (Arthur 2012).

The southern North Island forest gecko and Southern bell frog have been recorded on the eastern shores of Lake Wairarapa with a recent sighting of the latter in August 2012 at Wairio. The threatened Wellington green gecko, common gecko and common skink were recorded in the general lake area and most likely inhabit Wairio (Pickard \& Towns 1998).

The native freshwater fish species; common bully, mullet and common smelt, and the introduced species perch, rudd and goldfish have been observed recently in ponds at Wairio Wetland by GWRC workers. There have also been past sightings of the indigenous inanaga (whitebait) and two nationally vulnerable species the brown mudfish and giant kokopu; however their present abundance and distribution is unknown (Airey et al. 2000). The only method of pest fish control is via recreational fishing on Lake Wairarapa. A complete freshwater macro-invertebrate survey has not been undertaken for the Lake Wairarapa catchment; however the tadpole shrimp (Lepiduris apus viridis) is known to inhabit nearby Boggy Pond (Airey et al. 2000).

Introduced mammalian species are common at Wairio and its surroundings. Beef cattle and sheep are grazed within fenced sections of the wetland. The European rabbit and hare are common in the area with cabbage tree seedlings frequently eaten. Hedgehogs, feral cats, rats and mustelids also inhabit the area (Beadel et al. 2000; Garrick et al. 2007). Recent predator trapping at the site and its close surroundings by GWRC caught thirty stoats, three cats and two ferrets. The Animal Health Board in association with GWRC specifically target possums in the area to prevent the spread of Tuberculosis to cattle with 1080 aerial drops the desired approach. No hare, rabbit or rat control is currently undertaken at the site. 


\subsubsection{Community restoration}

The Wairio Wetland Restoration Committee was formed in 2005 with the aim of sustainably managing and restoring the degraded wetland. The Committee is composed of representatives from Ducks Unlimited, Greater Wellington Regional Council, The Department of Conservation, Fish and Game Council, Forest and Bird, The Queen Elizabeth Trust, local iwi and resident farmers. The Committee has taken a staged approach to management of the site with three areas totalling 21.9 ha having had restorative activities. Restoration activities to date have included large-scale native tree planting, earthworks (including pond creation), weed control, and fence construction.

Local volunteers are common at planting days with children from nearby Pirinoa, Martinborough and Kahutara primary Schools, and students from Taratahi Agricultural Training Centre assisting.

Students from Victoria University of Wellington have also been approached to undertake research at Wairio since 2011, beginning with a masters-level research project conducted by Bridget Johnson. Tapuwa Marapara and Cheng Shi (students from Victoria University) are also undergoing research in the area.

\subsubsection{Management}

The Wairio Wetland is owned by the Department of Conservation (DOC). However, management of Wairio Wetland is undertaken by Ducks Unlimited which convenes and chairs the Wairio Wetland Restoration Committee, comprising members from the interested parties on the Lake Wairarapa Coordinating Committee (LWCC), as well as the Manager of Land Corp's Wairio Farm which leases the surrounding land from DOC and other community groups. 


\subsection{Research aims}

The overall aim of this research is to help inform future restoration efforts and management practices undertaken for wetland restoration, especially with reference to Wairio Wetland, Wairarapa. The two areas of focus in my thesis are:

1) Examining the effects of eutrophication on diversity, biomass and structure of a wetland plant community.

2) Investigating whether specific pre-planting and after-care planting treatments can facilitate greater species survival and growth rates of native woody vegetation.

This research was conducted with support and funding from the Wairio Wetland Restoration Committee.

\subsection{Thesis structure}

There are three remaining chapters in this thesis. Chapter two examines the changes in biomass, diversity and composition of a wetland plant community at Wairio Wetland in response to the addition of nitrate and phosphate fertiliser. Chapter three assesses the role of various planting management treatments in facilitating the survival and growth of native woody vegetation planted at Wairio. Chapters two and three are arranged independently for submission to a Journal and may contain some repetition. Chapter four summarises the general conclusions from the previous two chapters and suggests recommendations for future restoration activities to be undertaken at Wairio Wetland. 


\subsection{References}

Acharya G, Barbier EB 2000. Valuing groundwater recharge through agricultural production in the Hadejia-Nguru wetlands in northern Nigeria. Agricultural Economics 22(3): 247-259.

Airey S, Puentener R, Rebergen A 2000. Lake Wairarapa wetlands action plan 2000 - 2010. Wellington, Department of Conservation. 68 p.

Armentano TV, Menges ES 1990. Patterns of change in the carbon balance of organic soil wetlands of the temperate zone. Journal of Ecology 74: 755-774.

Armstrong B 2004. Lower Valley Development Scheme Review. Wellington, MWH New Zealand Ltd. 41 p.

Aronson J, van Andel J 2006. Challenges for ecological theory. In: van Andel J, Aronson J eds. Restoration ecology: the new frontier. Maryland, Blackwell Publishing. Pp. 223-233.

Arthur N 2012. Eastern Wairarapa Bird Survey. Unpublished data. Wellington, Greater Wellington Regional Council.

Ausseil AE, WL Chadderton, P Gerbeaux, Stephens RTT, Leathwick JR 2011. Applying systematic conservation planning principles to palustrine and inland saline wetlands of New Zealand. Freshwater Biology 56: 142-161.

Badiou P, McDougal R, Pennock D, Clark B 2011. Greenhouse gas emissions and carbon sequestration potential in restored wetlands of the Canadian prairie pothole region. Wetlands Ecology and Management 19(3): 237-256.

Batten KM, Scow KM, Davies KF, Harrison SP 2006. Two invasive plants alter soil microbial community composition in serpentine grasslands. Biological Invasions 8: 217-230. 
Beadel S, Perfect A, Rebergen A, Sawyer J 2000. Wairarapa Plains Ecological District: Survey Report for the Protected Natural Areas Programme. Wellington, Department of Conservation. 203 p.

Bedford LB 1996. The need to define hydrologic equivalence at the landscape scale for freshwater wetland mitigation. Ecological Applications 6: 57-68.

Bell SS, Fonesca MS, Motten LB 1997. Linking Restoration and Landscape Ecology. Restoration Ecology 5(4): 318-323.

Bennett EM, Carpenter SR, Caraco NF 2001. Human Impact on Erodable Phosphorus and Eutrophication: A Global Perspective. Bioscience 51(3): 227- 234.

Bodmin K 2010. Weeds. In: Peters M, Clarkson B eds. Wetland Restoration: A Handbook for New Zealand Freshwater Systems. Lincoln, Manaaki Whenua Press. 273 p.

Boers AM, Frieswyk CB, Verhoeven JTA, Zedler JB 2006. Contrasting Approaches to the Restoration of Diverse Vegetation in Herbaceous Wetlands. In: Bobbink R, Beltman B, Verhoeven JTA, Whigham DF eds. Wetlands: Functioning, Biodiversity Conservation, and Restoration. New York, Springer. 315 p.

Bourdôt G 2012. Undermining Weeds: Progress Update. Lincoln, AgResearch Limited. 4 p.

Bridgham SD, Richardson CJ 1993. Hydrology and nutrient gradients in North Carolina peatlands. Wetlands 13: 207-218.

Brix H 1997. Do Macrophytes play a role in constructed treatment wetlands? Water and Science Technology 35(5): 11-17. 
Bruland GL, Hanchey MF, Richardson CJ 2003. Effects of agriculture and wetland restoration on hydrology, soils, and water quality of a Carolina bay complex. Wetlands Ecology and Management 11: 141-156.

Cairns Jr J 2000. Setting ecological restoration goals for technical feasibility and scientific validity. Ecological Engineering 15: 171-180.

Campbell D 2010. Hydrology. In: Peters M, Clarkson B eds. Wetland Restoration: A Handbook for New Zealand Freshwater Systems. Lincoln, Manaaki Whenua Press. $273 p$.

Carpenter SR 2005. Eutrophication of aquatic ecosystems: Bistability and soil phosphorus. Proceedings of the National Academy of Sciences of the United States of America 102(29): 10002-10005.

Carpenter SR, Caraco NF, Correll DL, Howarth RW, Sharpley AN, Smith VH 1998. Nonpoint Pollution of Surface Waters with Phosphorus and Nitrogen. Ecological Applications 8(3): 559-568.

Carter V 1996. Wetland hydrology, water quality, and associated functions. In: Fretwell JD, Williams JS, Redman PJ eds. National water summary on wetland resources. Virginia, US Geological Survey Water-Supply Paper 2425. Pp. 35-49.

Casanova MT, Brock MA 2000. How do depth, duration and frequency of flooding influence the establishment of wetland plant communities? Plant Ecology 147: 237-250.

Charles H and Dukes JS 2007. Impacts of Invasive Species on Ecosystem Services. In: Nentwig W ed. Biological Invasions. Berlin, Springer Verlag. Pp. 217-237. 
Cheng S, Grosse W, Karrenbrock F, Thoennessen M 2002. Efficiency of constructed wetlands in decontamination of water polluted by heavy metals. Ecological Engineering 18: 317-325.

Cherry JA 2012. Ecology of Wetland Ecosystems: Water, Substrate, and Life. Nature Education Knowledge 3(10): 16.

Clarkson B \& Peters M 2010. Revegetation. In: Peters M, Clarkson B eds. Wetland Restoration: A Handbook for New Zealand Freshwater Systems. Lincoln, Manaaki Whenua Press. 273 p.

Clewell AF, Aronson J 2007. Ecological restoration: principles, values, and structure of an emerging profession. Washington, Island Press. 216 p.

Clewell A, Rieger JP 1997. What Practitioners Need from Restoration Ecologists. Restoration Ecology 5(4): 350-354.

Connel JH 1983. On the prevalence and relevant importance of interspecific competition: evidence from field experiments. American naturalist 122: 240-285.

Costanza R, d'Arge R, de Groot RS, Farber S, Grasso M, Hannon B, Limburg K, Naeem S, O'Neill RV, Paruelo J, Raskin RG, Sutton P, van den Belt M 1997. The value of the world's ecosystem services and natural capital. Nature 387: 253-260.

Cowardin LM, Carter V, Golet FC, LaRoe ET 1979. Classification of Wetlands and Deepwater Habitats of the United States. Washington, U. S. Department of the Interior, Fish and Wildlife Service. 131 p.

Cromarty P, Scott DA 1996. A directory of wetlands in New Zealand. Wellington, Department of Conservation. 395 p. 
Davis JA, Froend R 1999. Loss and degradation of wetlands in southwestern Australia: underlying causes, consequences and solutions. Wetlands Ecology and Management 7(1-2): 13-23.

Ehrenfeld JG 2000. Defining the Limits of Restoration: The Need for Realistic Goals. Restoration Ecology 8(1): 2-9.

Ehrenfield JG 2003. Effects of Exotic Plant Invasions on Soil Nutrient Cycling Processes. Ecosystems 6: 503-523.

Engelhardt KAM, Ritchie ME 2001. Effects of macrophyte species richness on wetland ecosystem functioning and services. Nature 411: 687-689.

Finlayson CM, Davidson NC, Spiers AG, Stevenson NJ 1999. Global wetland inventory current status and future priorities. Marine and Freshwater Research 50(8): 717727.

Flinn KM, Lechowicz MJ, Waterway MJ 2008. Plant species diversity and composition of wetlands within an upland forest. American Journal of Botany 95(10): 1216-1224.

Follstad Shah JJ, Dahm CN, Gloss SP, Bernhard ES 2007. River and Riparian Restoration in the Southwest: Results of the National River Restoration Science Synthesis Project. Restoration Ecology 15(3): 550-562.

Forsyth F, Dixon M 2004. Wairarapa Wetlands - an overview. Wellington, Greater Wellington Regional Council. 44 p.

Garrick A, Bishop C, Beadel S, Rate S 2007. Restoration strategy and implementation plan for indigenous vegetation and plant species of the eastern shoreline of Lake Wairarapa: final working draft. Rotorua, Wildlands Consultants Ltd. 66 p. 
Gerbeaux P 2002. The Ramsar Convention: A review of wetland management in New Zealand. Pacific Ecologist 4: 37-41.

Gibbs JP 1995. Hydrologic needs of wetland animals. In: Nierenberg WA ed. Encyclopaedia of environmental biology, volume 2. New York, Academic Press. Pp. 267-276.

Gibbs JP 2000. Wetland Loss and Biodiversity Conservation. Conservation Biology 14(1): 314317.

Goldberg D 1990. Components of resource competition in plant communities. In: Grace JB, Tilman D eds. Perspectives on Plant Competition. San Diego, Academic Press. Pp. 2749.

Gottschall N, Boutin C, Crolla A, Kinsley C, Champagne P 2007. The role of plants in the removal of nutrients at a constructed wetland treating agricultural (dairy) wastewater, Ontario, Canada. Ecological Engineering 29(2): 154-163.

Gough L, Grace JB 1998. Effects of flooding, salinity and herbivory on coastal plant communities, Louisiana, United States. Oecologia 117(4): 527-535.

Greater Wellington Regional Council 2009. Lower Wairarapa Valley Development Scheme. Wellington, Greater Wellington Regional Council. Retrieved 28 September 2012, from http://www.gw.govt.nz/lower-wairarapa-valley-development-scheme/.

Greater Wellington Regional Council 2011. January 2011 hydrological summary. Wellington, GWRC Environmental monitoring and investigations department. Retrieved 4 October 2012, from http://www.gw.govt.nz/assets/Our-Environment/Environmental -monitoring/January-2011-hydrological-summary.pdf.

Greater Wellington Regional Council 2012. Air, land and water in the Wellington Region: states and trends. Wellington, Greater Wellington Regional Council. 30 p. 
Greenway M 2005. The role of constructed wetlands in secondary effluent treatment and water reuse in subtropical and arid Australia. Ecological Engineering 25: 501-509.

Greipsson S 2011. Restoration Ecology. Maryland, Jones \& Bartlett Learning. 408 p.

Harris JA, van Diggelen R 2006. Ecological restoration as a project for global society. In: van Andel J, Aronson J eds. Restoration ecology: the new frontier. Maryland, Blackwell Publishing. Pp. 3-15.

Heine JC 1975. Interim report on soils of Wairarapa Valley, New Zealand. Palmerston North, New Zealand Department of Scientific and Industrial Research. 37 p.

Heslop I 1995. The Upper Ruamahanga River and Floodplain Investigation - Phase 1 - Issues. Masterton, Greater Wellington Regional Council.

Hey DL, Philippi NS 1995. Flood Reduction through Wetland Restoration: The Upper Mississippi River Basin as a Case History. Restoration Ecology 3(1): 4-17.

Hill 1963. The vegetation of the Wairarapa in the Mid-Nineteenth Century. Tuatara 11(2): 83-89.

Hobbs RJ, Norton DA 1996. Towards a Conceptual Framework for Restoration Ecology. Restoration Ecology 4(2): 93-110.

Hollis T, Bedding J 1994. Can we stop the wetlands from drying up?. New Scientist 2(1932): $31-35$.

Jackson MB 2006. Plant Survival in Wet Environments: Resilience and Escape Mediated by Shoot Systems. In: Bobbink R, Beltman B, Verhoeven JTA, Whigham DF eds. Wetlands: Functioning, Biodiversity Conservation, and Restoration. New York, Springer. 315 p. 
James CS, Capon SJ, White MG, Rayburg SC, Thoms MC 2007. Spatial variability of the soil seed bank in a heterogeneous ephemeral wetland system in semi-arid Australia. Plant Ecology 190(2): 205-217.

Johnson P, Gerbeaux P 2004. Wetland Types in New Zealand. Wellington, Department of Conservation. $11 \mathrm{p}$.

Johnson P, Rogers G 2003. Ephemeral wetlands and their turfs in New Zealand. Wellington, Department of Conservation. $88 \mathrm{p}$.

Johnston CA 1991. Sediment and nutrient retention by freshwater wetlands: Effects on surface water quality. Critical Reviews in Environmental Control 21(5-6): 491-565.

Kayranli B, Scholz M, Mustafa A, Hedmark A 2010. Carbon Storage and Fluxes within Freshwater Wetlands: a Critical Review. Wetlands 30:111-124.

Larson JS, Adamus PR, Clairain EJ 1989. Functional assessment of freshwater wetlands: a manual and training outline. Oregon, U.S. Environmental Protection Agency Corvallis Environmental Research Laboratory. 62 p.

Law JR 2012. Wairio Wetland restoration project: Eastern shore of Lake Wairarapa. Ducks Unlimited. Retrieved August 16 2012, from http://www.ducks.org.nz/Wairio\%20Rest oration\%20Feb\%2012.pdf.

Pickard CR, Towns DR 1998. Atlas of Amphibians and Reptiles of New Zealand. Wellington, Department of Conservation. $59 \mathrm{p}$.

McEwen WM 1987. Ecological Regions and Districts of New Zealand $3^{\text {ed }}$. Wellington, Department of Conservation. $35 \mathrm{p}$. 
McFadgen B 2003. Archeology of the Wellington Conservancy: Wairarapa a study in tectonic archaeology. Wellington, Department of Conservation. 94 p.

McGlone MS 2009. Postglacial history of New Zealand wetlands and implications for their Conservation. New Zealand Journal of Ecology 33(1): 1-23.

Mclntyre R 2002. The Canoes of Kupe A history of the Martinborough District. Wellington, Victoria University Press. 344 p.

Middleton B 1999. Wetland restoration. Flood pulsing and disturbance dynamics. New York, John Wiley. 400 p.

Ming J, Xian-guo L, Lin-shu X, Li-juan C, Shouzheng T 2007. Flood mitigation benefit of wetland soil - A case study in Momoge National Nature Reserve in China. Ecological Economics 61(2-3): 217-223.

Mitsch WJ, Day Jr JW, Gilliam JW, Groffman PM, Hey DL, Randall GW, Wang N 2001. Reducing Nitrogen Loading to the Gulf of Mexico from the Mississippi River Basin: Strategies to Counter a Persistent Ecological Problem. BioScience 51(5): 373-388.

Mitsch WJ, Gosselink JG 2007. Wetlands 4ed. New Jersey, John Wiley and Sons. 582 p.

Moore MM, Covington WW, Fule PZ 1999. Reference conditions and ecological restoration: a southwestern ponderosa pine perspective. Ecological Applications 9(4): 12661277.

National Wetland Trust of New Zealand 1999. National Wetland Trust Business Plan 20002005. Pukekohe, National Wetland Trust of New Zealand. 14 p. 
Naugle DE, Johnson RR, Estey ME, Higgins KF 2001. A landscape approach to conserving wetland bird habitat in the prairie pothole region of eastern South Dakota. Wetlands 21(1): 1-17.

Nixon SW 1995. Coastal marine eutrophication: a definition, social causes, and future concerns. Ophelia 41: 199-219.

Ogle CC, Moss TC, Druce AP 1990. Vascular flora of Lake Wairarapa and its adjacent wetlands. Science and Research Series No. 20. Wellington, Department of Conservation. 24 p.

Perrie A 2005. Lake Wairarapa Water Quality Monitoring Technical Report. Wellington, Greater Wellington Regional Council. Retrieved 14 September 2012, from http://www.govt.nz/Home/Information \& services/Environmental monitoring/Lake levels.

Pezeshki SR 2001. Wetland plant responses to soil flooding. Environmental \& Experimental Botany 46(3): 299-312.

Porteous T 1993. Native Forest Restoration: A Practical Guide for Landowners. Wellington, QEII National Trust. 184 p.

Price J, Gross CL, Whalley W 2010. Prolonged summer flooding switched dominance from the invasive weed Lippia (Phyla canescens) to native species in one small, ephemeral wetland. Ecological Management \& Restoration 11(1): 61-63.

Ramsar Convention on Wetlands 2005. An Integrated Framework for Wetland Inventory, Assessment and Monitoring (IF-WIAM). Uganda, RAMSAR. Retrieved 2 May 2013, from http://www.ramsar.org/cda/en/ramsar-documents-cops-cop9-9th-meeting-ofthe-17353/main/ramsar/1-31-58-82\%5E17353_4000_0_. 
Ramsar Convention Secretariat 2013. The Ramsar Convention Manual: a guide to the Convention on Wetlands 6th ed. Switzerland, Ramsar Convention Secretariat. Retrieved 2 May 2013, from http://www.ramsar.org/pdf/lib/manual6-2013-e.pdf.

Ramsar Convention Secretariat 2014. The List of Wetlands of International Importance. Switzerland, Ramsar Convention Secretariat. Retrieved 2 May 2013, from http:// www.ramsar.org/pdf/sitelist.pdf.

Reeves PN, Champion PD 2004. Effects of livestock grazing on wetlands: literature review. Hamilton, The National Institute of Water and Atmospheric Research. 38 p.

Reilly JF, Horne AJ, Miller CD 1999. Nitrate removal from a drinking water supply with large free-surface constructed wetlands prior to groundwater recharge. Ecological Engineering 14(1-2): 33-47.

Rekolainen S, Ekholm P, Heathwaite L, Lehtoranta J, Uusitalo R 2006. Off-site effects of erosion: eutrophication as an example. In: Boardman J, Poesen J eds. Soil Erosion in Europe. Chichester, Wiley. Pp. 775-789.

Robertson HA, Heather BD 1999. Effect of water levels on the seasonal use of Lake Wairarapa by waders. Notornis 46: 79-88.

Rodwell JS 1998. British Plant Communities Volume 3, Grasslands and montane communities. Cambridge, Cambridge University Press. 552 p.

Roth RA 2009. Freshwater Aquatic Biomes. Westport, Greenwood Press. 237 p.

Ruhren S, Handel SN 2003. Herbivory Constrains Survival, Reproduction and Mutualisms When Restoring Nine Temperate Forest Herbs. Journal of the Torrey Botanical Society 130(1): 34-42. 
Semlitsch RD, Bodie JR 2003. Biological Criteria for Buffer Zones around Wetlands and Riparian Habitats for Amphibians and Reptiles. Conservation Biology 17(5): 12191228.

Society for Ecological Restoration 2004. The SER International Primer on Ecological Restoration. Tucson, Society for Ecological Restoration International. 15 p.

Smith VH 2003. Eutrophication of Freshwater and Coastal Marine Ecosystems: A Global Problem. Environmental Science and Pollution Research 10(2): 126-139.

Smith VH, Tilman GD, Nekola JC 1999. Eutrophication: impacts of excess nutrient inputs on freshwater, marine, and terrestrial ecosystems. Environmental Pollution 100: 179196.

Sorrell BK, Partridge TR, Clarkson BR, Jackson RJ, Chagué-Goff C, Ekanayake J, Payne J, Gerbeaux P and Grainger NPJ 2004. Soil environmental and vegetation responses to hydrological restoration in a partially drained polje fen in New Zealand. Wetlands Ecology and Management 15(5):361-383.

Stinson KA, Campbell SA, Powell JR, Wolfe BE, Callaway RM, Thelen GC, Hallett SG, Prati D, Klironomos JN 2006. Invasive plants suppresses the growth of native tree seedlings by disrupting belowground mutualisms. PLoS Biology 4(5): 140-151.

Thompson Y, D’Angelo EM, Karathanasis AD, Sandefur BC 2012. Plant community composition as a function of geochemistry and hydrology in three Appalachian wetlands. Ecohydrology 5(4): 389-400.

Tilman D 1997. Mechanisms of plant competition. In: M Crawley. Plant ecology 2ed. Blackwell science, Oxford, England. Pp. 239-261. 
Ulrich D 2005. A review on habitats, plant traits and vegetation of ephemeral wetlands - a global perspective. Phytocoenologia 35(2-3): 533-706.

Van Asselen S, Verburg PH, Vermaat JE, Janse JH 2013. Drivers of wetland conversion: a global meta-analysis. PLoS One 8(11): e81292.

van der Kamp G and Hayashi M 1998. The Groundwater Recharge Function of Small Wetlands in the Semi-Arid Northern Prairies. Great Plains Research 8: 39-56.

van der Valk AG 2006. The Biology of Freshwater Wetlands. New York, Oxford University Press. 173p.

van Roon MR 2012. Wetlands in The Netherlands and New Zealand: Optimising biodiversity and carbon sequestration during urbanisation. Journal of Environmental Management 101: 143-150.

Vaughn KJ, Porensky LM, Wilkerson ML, Balachowski J, Peffer E, Riginos C, Young TP 2010. Restoration Ecology. Nature Education Knowledge 3(10): 66.

Warwick NWM, Brock MA 2003. Plant reproduction in temporary wetlands: the effects of seasonal timing, depth, and duration of flooding. Aquatic Botany 77: 153-167.

Williams DD 1996. Environmental constraints in temporary freshwaters and their consequences for the insect fauna. Journal of North American Benthological Society 15: 634-650.

Woodward RT, Wui Y-S 2001. The economic value of wetland services: a meta-analysis. Ecological Economics 37: 257-270.

Zedler PH 1987. The ecology of southern California vernal pools: a community profile. Washington, U.S. Fish and Wildlife Service. Biology Report 85 (7.11). 
Zedler JB 2000. Progress in wetland restoration ecology. Trends in Ecology and Evolution 15(10): 402-407.

Zedler JB, Kercher S 2004. Causes and Consequences of Invasive Plants in Wetlands: Opportunities, Opportunists, and Outcomes. Critical Reviews in Plant Sciences 23(5): 431-452. 


\section{Chapter 2}

\section{THE EFFECTS OF EUTROPHICATION ON STRUCTURE, DIVERSITY AND BIOMASS OF A PLANT COMMUNITY AT WAIRIO WETLAND}

\subsection{Introduction}

Soil and water eutrophication, the increasing accumulation of excess nutrients in an environment (Bennett et al. 2001; Nixon 1995), is a major threat to freshwater ecosystems worldwide (Smith \& Schindler 2009). Eutrophication of freshwater systems can be attributed to both external and internal agents that increase nutrient levels in the soil and water (Boers et al. 2006). External agents of eutrophication can include nutrient runoff from agricultural areas, construction work, urban land-use, sewerage systems or industrial chemical waste (Carpenter 2005; Sánchez-Carillo et al. 2011). Nutrient loading from agricultural areas is the most common non-point source of nutrient runoff into aquatic systems (Carpenter et al. 1998; Gotschall et al. 2007), due to various farm activities and by-products such as excess fertiliser application on soils, cattle effluent, and milking shed wastewater leaching nutrients into soils and local waterways (Boers et al. 2006). This phenomenon is common in New Zealand with an abundance of dairy farms operating throughout the country, contributing to annual export earnings in excess of $\$ 12$ billion (Statistics New Zealand 2013). Primarily phosphorous and secondarily nitrogen are the principal nutrients leached into waterways from agricultural runoff (Carpenter et al. 1998; Smith et al. 1999). Internal agents of eutrophication in a wetland can be attributed to hydrological regimes acting at a site. Fluctuating water levels can lead to the release and capture of nutrients in the soil or water and subsequent accumulation. Nitrogen accumulation in soil is common during periods of drying out (Olde Venterink et al. 2002), and phosphorous accumulation can occur during periods of long-term water inundation at a wetland site (Boers et al. 2006).

Excess nutrients found in eutrophic waters and soil can facilitate the growth of phytoplankton and toxic algae blooms (Rekolainen et al. 2006; Smith 2003), promote hypoxic conditions (oxygen depletion) or anoxic events (total depletion of oxygen) that can 
kill marine life (Carpenter 2005; Smith 2003), change plant species communities (Smith 1998), and lead to loss of plant and animal biodiversity (Carpenter et al. 1998). These environmental effects can lead to vast social impacts such as contamination of freshwater drinking supplies (Harper 1992; Havens et al. 2003), loss of commercial or recreational fisheries, animal poisoning, a rise in water-borne infectious diseases (Smith \& Schindler 2009), and restrictions on recreational activities. These negative effects of eutrophication can last long-term even when the source of nutrient loading ceases, which can lead to practical problems in ecological restoration of degraded wetlands, where the success of native revegetation planting and reinstatement of hydrology relies on being able to alter soil and water nutrient levels.

Soil and water eutrophication of freshwater ecosystems can cause changes in biomass, biodiversity and structure of plant communities (Keddy 2000; Smith \& Schindler 2009; Stevens et al. 2010). Nitrogen and phosphorous are common, limiting nutrients in wetlands that are lost via drainage (Iverson et al. 2010; Vance 2001; Vitousek and Howarth 1991; Vymazal et al. 2008). When nitrogen and phosphorous are in abundant supply (aka nutrient loading) it can lead to an increase in overall plant biomass (Brauer et al. 2012; Chase \& Knight 2006). Studies by Gough et al. (2000) in seven terrestrial ecosystems and Mahaney et al. (2004) in a wetland environment, reported an increase in plant growth up to $50 \%$ and increase in overall plant biomass associated with nitrate addition to the respective plant communities. However studies by Marcar et al. (2000) in saline seeps found no change in plant growth or survival and Kneitel \& Lessin (2010) in Calfornia vernal pools found a decrease in plant cover associated with fertiliser addition. Greater plant biomass can increase competition between plants for limited light in an environment (Brauer et al. 2012), which typically favours fast-growing competitive species at the expense of others (Ceulemans et al. 2012; Hautier et al. 2009). Plant communities in environments with deficient nutrient levels could improve growth and survival with nutrient loading (Grattan \& Grieve 1992). However, in areas with excess or adequate nutrient levels, nutrient loading could be detrimental or have no effect on plant growth and survival. 
Soil and water eutrophication can have long-term negative effects on plant biodiversity in freshwater ecosystems (Ceulemans et al. 2012; Keddy 2000; Smith \& Schindler 2009; Stevens 2004). In accordance with the 'niche dimension' hypothesis, that increasing limited nutrients in an environment can lead to a reduction in plant numbers, Harpole \& Tilman (2007) found that the addition of phosphate, nitrate, and moisture to a grassland at Sedgewick reserve, California resulted in a reduction in overall plant biodiversity at the site. Many studies have shown that invasive or common plant species respond positively to nutrient addition and can outcompete native or rare species, contributing to a homogenous environment (Brooks 2003; Dawson et al. 2012; Maurer \& Zedler 2002). This phenomenon was found in a study by Green and Galatowitsch (2002), where nitrogen addition to plants in a constructed wetland in Minnesota resulted in an increase in invasive species, reduction in native species and overall reduction in species diversity. Houlahan et al. (2006) studied plant communities in 74 wetlands in Southeastern Ontario, Canada and found that increasing levels of phosphate and nitrate in the water and soil was consistent with a decrease in plant species richness and reduction in native and rare species, suggesting they are more sensitive to nutrient levels. Tyler et al. (2007) found that after nitrogen addition to an estuary plant community in San Francisco Bay, USA, a non-native intertidal grass (S. alterniflora) increased in density and biomass at the site, becoming the dominant competitor and leading to reductions in densities of a primary native grass species (S. virginica).

Schedonorus arundinaceus (tall fescue) is a common invasive weed of wetlands (Champion 1998; Davis \& Meurk 2001) that is present at Wairio Wetland. Potential proliferation of this species in response to nutrient addition could lead to disastrous effects on the native plant community. Agrostis capillaris (browntop) and Agrostis stolonifera (creeping bent grass) are known as strong competitors (Lenssen et al. 2004; Timmins \& Mackenzie 1995), and Bidens frondosa (beggars tick), Holcus lanatus (Yorkshire fog), and Rumex obtusifolius (broadleaved dock) are common environmental weeds (Champion 1998; Davis \& Meurk 2001; Groves 1999; Zaller 2004) present at the site that outcompete native species and could further benefit from nutrient addition. Other studies have found evidence of $A$. stolonifera and $H$. lanatus growing well in high nutrient sites (Goodwin et al. 1998; Timmins \& MacKenzie 1995) and $R$. obtusifolius responding positively to high levels of nitrogen addition 
(Jeangros \& Nösberger 1990). Lotus pedunculatus (lotus) is an exotic nitrogen fixing legume found at Wairio that favours low soil nutrient levels and may decrease in densities with nutrient addition (Honsova et al. 2007; Lambert et al. 1986; NZPCN 2013). Eleocharis acuta (sharp-spike sedge) is a small rare native species found at Wairio that is commonly outcompeted by larger species which could be favoured with nutrient addition at the site (Champion 1998). The native sedge Schoenoplectus pungens (three square) can survive in high soil salinity which could potentially occur with over fertilisation of the site (Albert et al. 2013), and the native sedge Isolepis prolifera is commonly found in eutrophic areas so may respond positively to nutrient addition (NZPCN 2013).

Changes in plant community structure from nutrient overload, specifically the promotion of non-native dominated vegetation (Boers et al. 2006), can lead to reduced ecosystem functioning as a whole for wetlands (Engelhardt \& Ritchie 2001; Scheffer et al. 2001; Schindler 2006). Altered soil microbial communities (Angeloni et al. 2006), changes in nutrient cycling (Tyler et al. 2007), facilitation of non-native species invasions (Chase \& Knight 2006), and a reduction in native vegetation and invertebrate populations are common issues in landscapes dominated by invasive plants. Haddad et al. (2009) found that a reduction in plant species diversity, with an increase in invasive species, at the Cedar Creek Science Research Reserve in Minnesota, USA led to a significant reduction in arthropod richness. Therefore it is crucial to understand the effects eutrophication may have on wetland plants to ensure restoration is successful and that the ecosystem can fully recover.

At the study site, Wairio Wetland, the restoration committee have planned to divert agriculturally sourced potentially nutrient-rich water from nearby Oporua Spillway through the wetland in order to increase water filtration with the aim to improve water quality in Lake Wairarapa. However the effects of high nutrient load on the plant species at the site are unknown. The practical goal of this project is to help inform the Wairio Wetland Restoration Committee the possible effects excess nutrient loading may have on vegetation at the site. The two research aims are: 1) to examine changes in plant community biomass in response to nutrient enrichment, and 2) to survey changes in plant community diversity and structure in response to nutrient enrichment. This involved a nutrient enrichment 
experiment at the wetland, where two levels of phosphate and nitrate were applied to vegetation at the site with the response of plants monitored over a five month period. I tested the hypotheses: 1 ) that plant biomass will be greatest under high nutrient conditions, 2) that plant diversity will be the lowest under high nutrient conditions, and 3) that common invasive species will respond positively to nutrient addition and outcompete sensitive, rare and native species. 


\subsection{Methods}

\subsubsection{Study site}

This study took place over a five month period from December 2012 to May 2013 at Wairio Wetland, situated on the eastern shores of Lake Wairarapa, North Island, New Zealand. The former kahikatea-dominant forest wetland has had a history of degradation since Maori and European settlement. Felling of large trees, followed by draining of the wetland during the Lower Wairarapa Valley Development Scheme (LWVDS) in the 1960 and 1970's, division from nearby lagoons and ponds with the construction of Parera Road, eutrophication from sheep and cattle farming, and exotic weed invasion have all contributed to degradation of the wetland. Members of the local community formed the Wairio Wetland Restoration Committee in 2005 with the aim of restoring the wetland to a near pristine condition. Three management areas at the site known as Stage 1, 2 and 3 have been the subject of restoration activities to date including native tree planting, pond creation, weed control, cattle exclusion and fence construction (Figure 4).

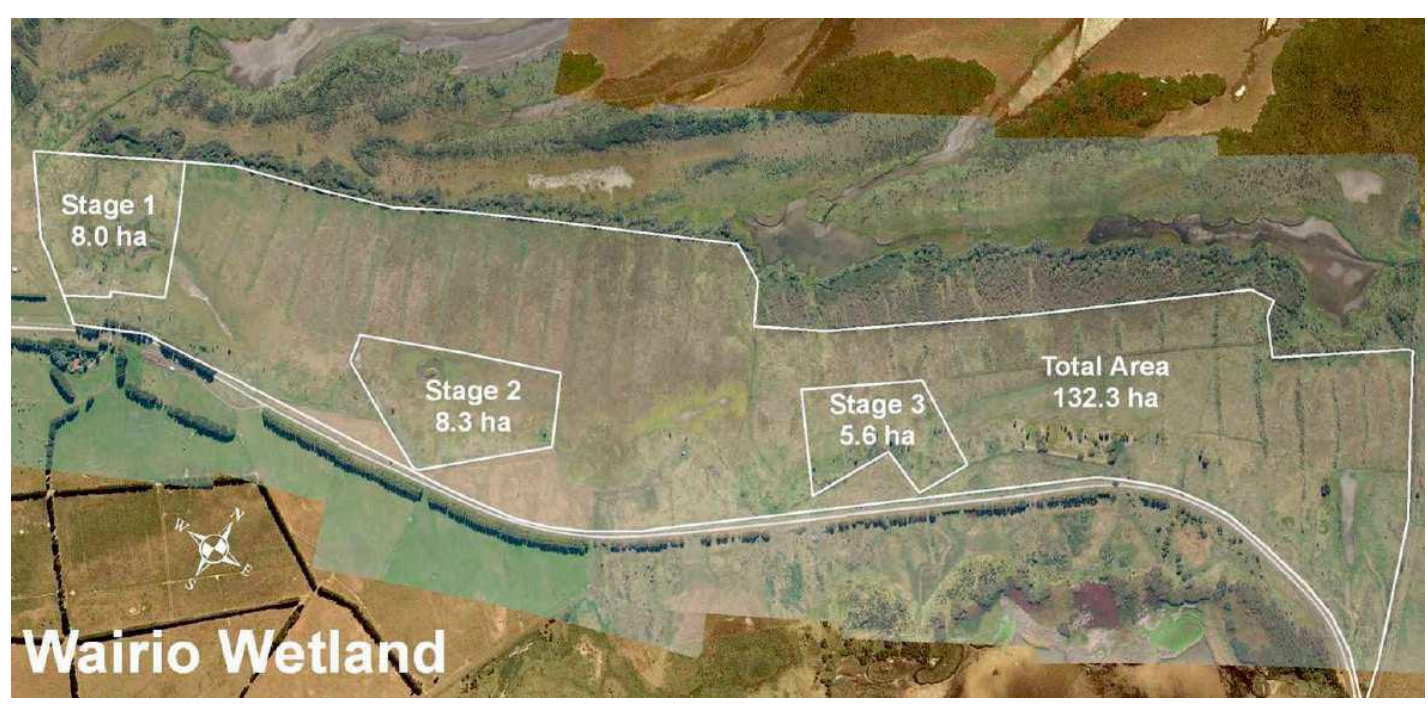

Figure 4 Aerial picture of Wairio Wetland, showing the location of Stage 1, 2 and 3 (Greater Wellington Regional Council, 2010).

This nutrient enrichment experiment was conducted in Stage 2 of Wairio Wetland. Stage 2 was used as summer grazing pasture for cattle and sheep up until 2007 when restoration activities began at the site including fence construction, creation of an earth dam and islands, and tree planting. The vegetation at Stage 2 is predominantly pasture grass, sedges 
and exotic weeds. The site is low lying and experiences flooding in the winter months and desiccation in the summer months when the water retreats.

\subsubsection{Experimental design and treatments}

A two-factor crossed design was used with five blocks (16 $\mathrm{m} \times 7 \mathrm{~m}$ ) of uniform vegetation selected in Stage 2 of Wairio Wetland, with blocks further split into ten plots $\left(4 \mathrm{~m}^{2}\right)$ (Figure 5). Blocks were chosen in low-lying areas in the middle of Stage 2 that had similar vegetation that was below knee height. Blocks 1-3 and 4-5 were separated due to tall vegetation making it difficult for all blocks to be located next to one another. Block and plot boundaries were outlined using bamboo sticks and builders wire to allow accurate repeated measurement (Appendix 2.6.1). Within a given block, the 10 plots were labelled $1 \mathrm{~A}-1 \mathrm{E}$ and 2A-2E to aid recording of data (Figure 5, Appendix 2.6.2).

Within a given block eight plots had various levels of granular phosphate $(P)$ and/or nitrate (N) applied (low $\mathrm{P}$, high $\mathrm{P}$, low $\mathrm{N}$, high $\mathrm{N}$, low $\mathrm{N}+\operatorname{low} \mathrm{P}$, high $\mathrm{N}+\operatorname{high} \mathrm{P}, \operatorname{low} \mathrm{N}+\operatorname{high} \mathrm{P}$, and high $\mathrm{N}+$ low $\mathrm{P}$ ), with the two remaining plots used as a control with no nutrients applied (Table 5, Appendix 2.6.2). Fertiliser was applied to plots at five times during the experimental period approximately every 4-5 weeks on 23 December 2012, 27 January 2013, 3 March 2013, 14 April 2013 and 19 May 2013 (Appendix 2.6.3). Plots were separated by a one metre width buffer zone to reduce plot contamination from fertiliser leakage (Figure 4). Fertiliser application rates were based on packet specifications for pastoral farming use in New Zealand. Fertiliser was evenly dispersed by hand over the treatment plots. Ravensdown granular Ammonium Sulphate $\left.\left(\left(\mathrm{NH}_{4}\right)^{2} \mathrm{SO}_{4}\right)\right)$ fertiliser containing $20.5 \%$ nitrogen and $24 \%$ sulphur was used as a source of nitrogen and applied at a low concentration of $52.5 \mathrm{~g}$ of nitrogen and a high concentration of $105.0 \mathrm{~g}$ of nitrogen per $4 \mathrm{~m}^{2}$ plot. Ravensdown Superphosphate $\left(\mathrm{Ca}\left(\mathrm{H}_{2} \mathrm{PO}_{4}\right)_{2}\right)$ fertiliser containing $9 \%$ phosphorous, $11 \%$ sulphur, and $20 \%$ calcium was used as a source of phosphorous and applied at a low concentration of $22.5 \mathrm{~g}$ of phosphorous and a high concentration of $45.0 \mathrm{~g}$ of phosphorous per $4 \mathrm{~m}^{2}$ plot. 


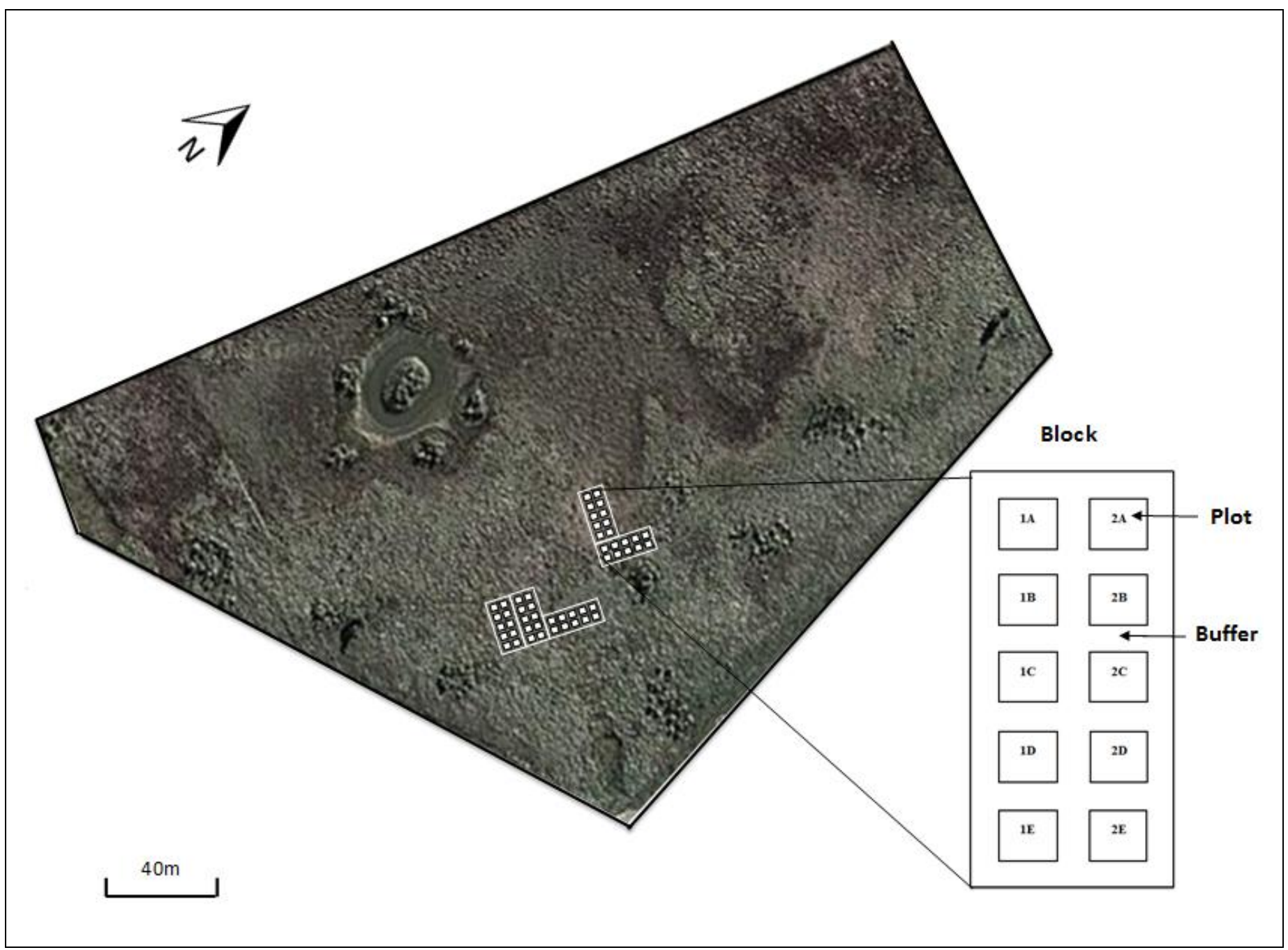

Figure 5 Map of Stage 2, Wairio Wetland showing the approximate location of the five experimental treatment blocks. Inset: Block layout with respective $4 \mathrm{~m}^{2}$ plots separated by a $1 \mathrm{~m}$ buffer zone. Plots were labelled $1 \mathrm{~A}-1 \mathrm{E}$ and $2 \mathrm{~A}-2 \mathrm{E}$ to assign different nutrient concentrations. 
Table 5 Within-block replication of fertiliser treatments. Treatment codes: $0=$ no addition of fertiliser (i.e. control), $1=$ low level addition, 2 = high level addition. $\checkmark=$ number of replicate plots per block ( 1 or 2 ). There were five blocks in total.

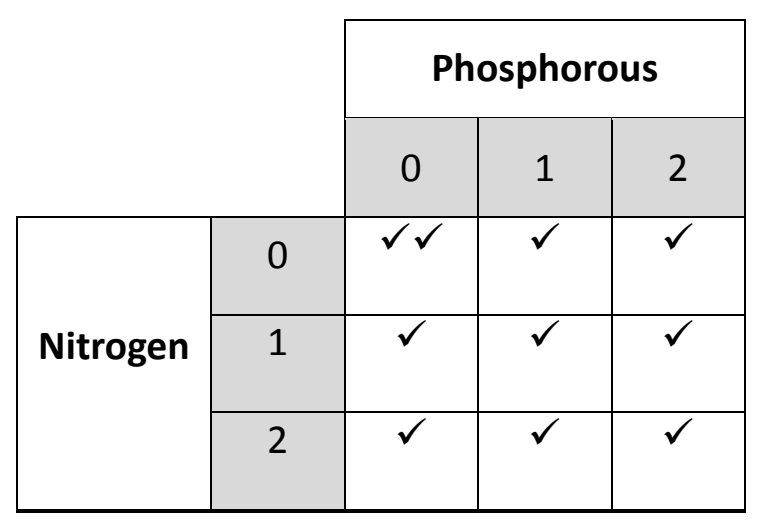

Each $4 \mathrm{~m}^{2}$ plot was further divided into $1 \mathrm{~m}^{2}$ quadrats for ease of sampling. Measurements of plant cover within each quadrat were taken every four to five weeks over the five month experimental period at the same time as fertiliser application (Appendix 2.6.3). Measurements included the percentage canopy cover of species and their average plant heights to the nearest five centimetres. Soil moisture and $\mathrm{pH}$ were measured within each quadrat using a hydrometer and pH meter (McGregor's 3 in 1 Soil tester) inserted into the soil in the middle of the quadrat. Soil moisture levels were given on an arbitrary scale between one and ten.

\subsubsection{Abiotic conditions}

Average weekly sunshine hours and average weekly rainfall $(\mathrm{mm})$ was noted for a year from July 2012 to July 2013 from a weather station located $6.6 \mathrm{~km}$ from Wairio Wetland at 85 Chishams Road, Dyerville.

\subsubsection{Soil analysis}

Soil samples were collected on April 26 2013, nine days after the fourth fertiliser application. Soil samples were taken from randomly selected control (ON:OP), low concentration (1N:1P), and high concentration $(2 \mathrm{~N}: 2 \mathrm{P})$ plots within each of the five blocks, totalling 15 soil samples for analysis (Figure 6). A two centimetre diameter hand auger corer was used to extract the soil cores. The top one centimetre vegetation layer of the soil core was removed and the 
next three centimetres of soil was collected and stored in plastic bags. Two soil cores were randomly taken from each quadrat in a given plot, thus eight soil cores were mixed to form a composite soil sample for each plot. The control plots were sampled first followed by the low concentration and then high concentration plots to reduce the risk of contamination and the soil corer was cleaned between samples. Samples were kept chilled overnight in the fridge and couriered the next day to ARL (Analytical Research Laboratories Limited) in Napier for analysis. Soil tests undertaken included an Olsen $\mathrm{P}$ test for plant available phosphorous, and Leco combustion test for total carbon and nitrogen levels in the soil.

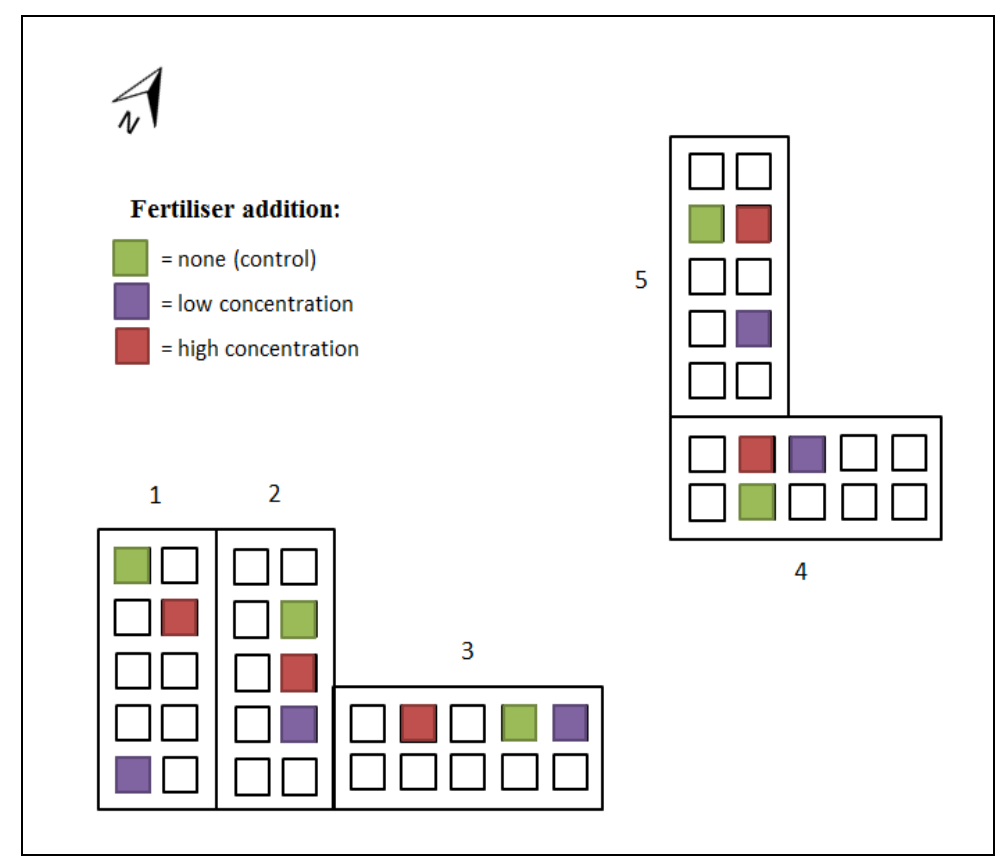

Figure 6 Map showing selected sites of soil sample collection from blocks one to five in Stage 2. Within each block one soil sample was taken from each of three fertiliser treatments: none, low-low, and high-high. Not drawn to scale.

\subsubsection{Data analysis}

\subsubsection{Community structure}

Line graphs were prepared to show the change in species percentage cover over the experimental period. Principle co-ordinate analyses (PCoA) were undertaken to 1) visualize the variation in wetland plant community structure across the 50 plots, in response to 
various levels of nitrate and/or phosphate addition, and 2) visualize the change in relative abundance of each species (percentage cover in May divided by percentage cover in December) in specific plots at the site with different nutrient levels. A dissimilarity matrix was constructed using the Bray Curtis distance. Bi-plot ordination method was used to visualise community composition relative to environmental variables. Rare species recorded in five plots or less at the site in either December or May were excluded from the PCoA. These species were B. frondosa, E. acuta, $H$ lanatus, $J$ articulatus, $R$ obtusifolius, and $S$ pungens.

\subsubsection{Plant biomass}

An index of biomass was estimated by multiplying percent cover $x$ average height of each species within each plot. Change in plant species biomass was calculated as the biomass in May minus biomass in December for each species within each plot. The effect of nutrient addition on the change in plant species biomass in plots at the site was evaluated using linear mixed effects models. Fixed effects included in the model were the concentration of nitrogen (none, low, high) and concentration of phosphorous (none, low, high) and the twoway interactions between these effects. A normal distribution for residuals was assumed. "Block" was included as a random effect. P-values are used throughout the paper for judging significance of fixed effects and are considered significant when $P \leq 0.05$. Models were not fitted to rare species recorded in five plots or less. These species were $B$. frondosa, H. lanatus, R. obtusifolius, and S. pungens.

\subsubsection{Plant diversity}

The change in plant diversity at the site in response to fertilizer treatment was evaluated by comparing the Shannon-Wiener diversity index (Equation 1), between plots in December and May.

\section{Equation 1 Shannon-Wiener diversity index}

$$
H^{\prime}=-\sum p_{i} \ln p_{i}
$$

Where: $H^{\prime}=$ Diversity index, $\mathrm{p}_{\mathrm{i}}=$ the proportion of individuals of species $\mathrm{i}, \mathrm{In}=$ natural logarithm. 
A linear mixed effects model was used to investigate the effect of nutrient addition on the change in Shannon-Wiener diversity index (plant community diversity). Fixed effects and random effects were the same as used in modelling plant biomass.

Data was analysed using the statistical programming software $R$ (Version 2.15.1) ( $R$ Development Core Team, 2013), using the 'pco' command from the R package 'labdsv' to undertake a principle coordinate analysis (Roberts 2013) and the 'Ime' command from the R package ' $\mathrm{nlme}$ ' to fit linear mixed effects models, using the restricted maximum likelihood method (Pinheiro et al. 2013). 


\subsection{Results}

\subsubsection{Description of Abiotic conditions}

Average weekly sunshine hours and rainfall was recorded from 1 July 2012 to 31 July 2013 from a local weather station (Figure 7). The greatest sunshine hours on average were between December 2012 and March 2013 during the experiment. Large rainfall events occurred in the first week of February 2013 and the third week of March 2013 during the experiment, and the third week of June 2013 after the experimental period.

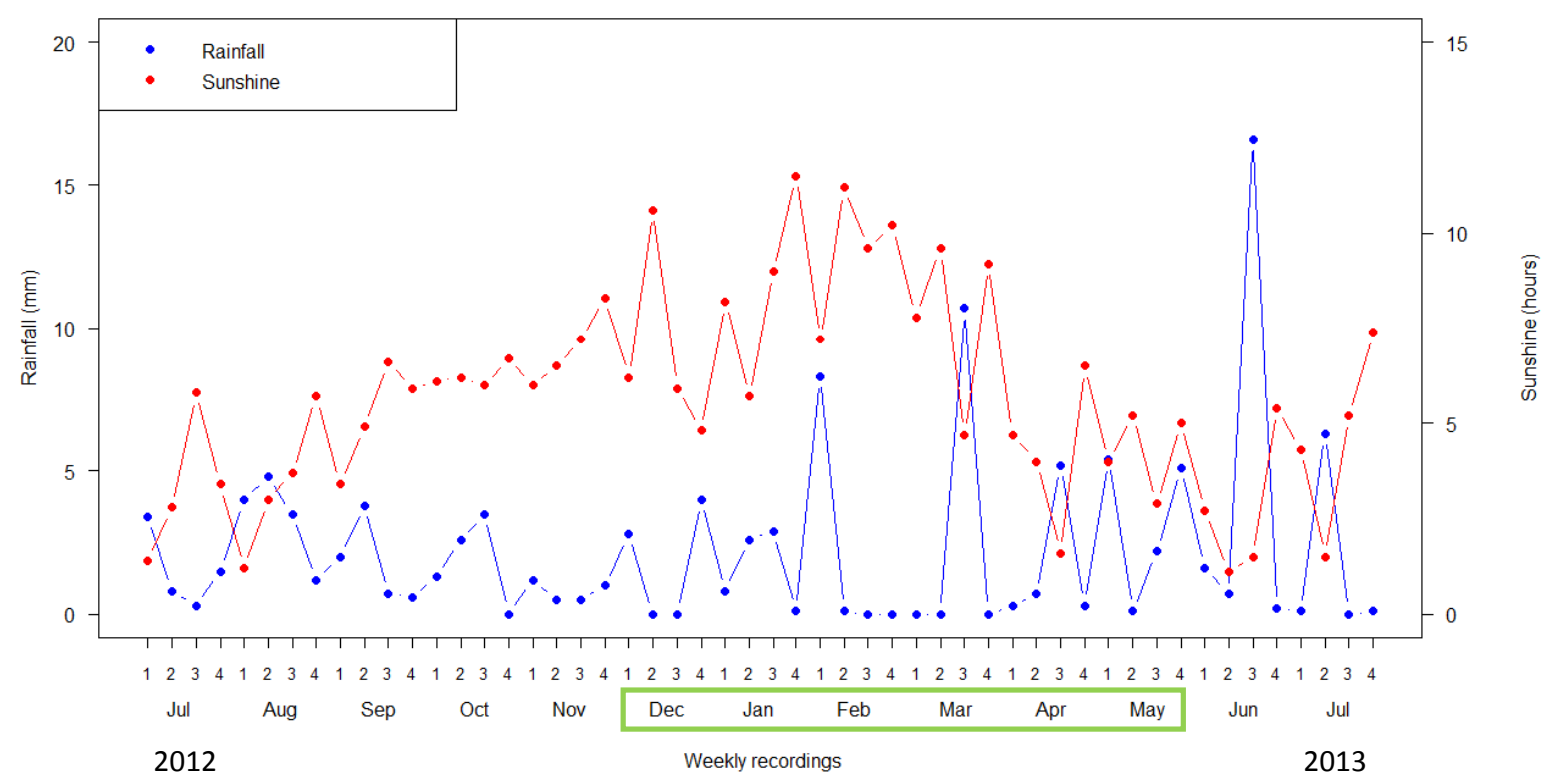

Figure 7 Weekly recordings of average rainfall $(\mathrm{mm})$ and average sunshine (hours) from 1 July 2012 to 31 July 2013 from a local weather station. The months the experiment took place are outlined in green. 


\subsubsection{Soil conditions}

Figure 8 suggests soil $\mathrm{pH}$ was reduced by the addition of nitrogen and/or phosphorous to plots at the site, however this effect was not statistically significant (Appendix 2.6.4). Soil moisture content was reduced by the addition of phosphorous fertiliser to plots at the site, however this effect was not statistically significant (Appendix 2.6.4).

(a) Phosphorous

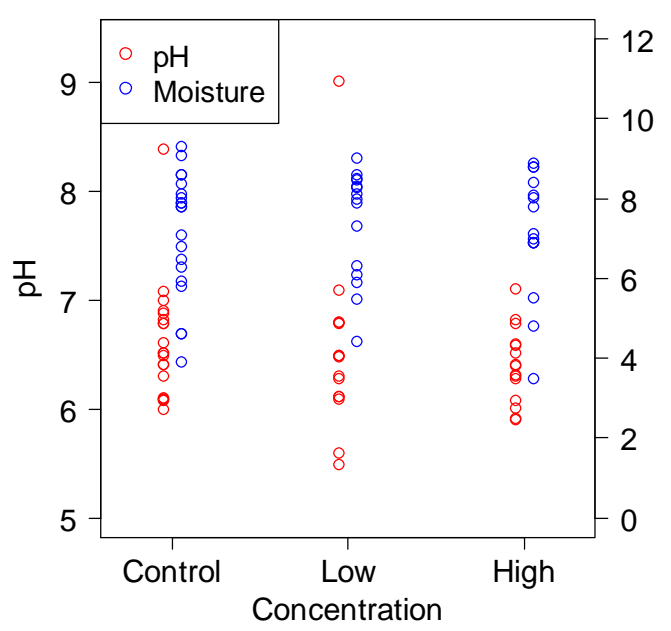

(b) Nitrogen

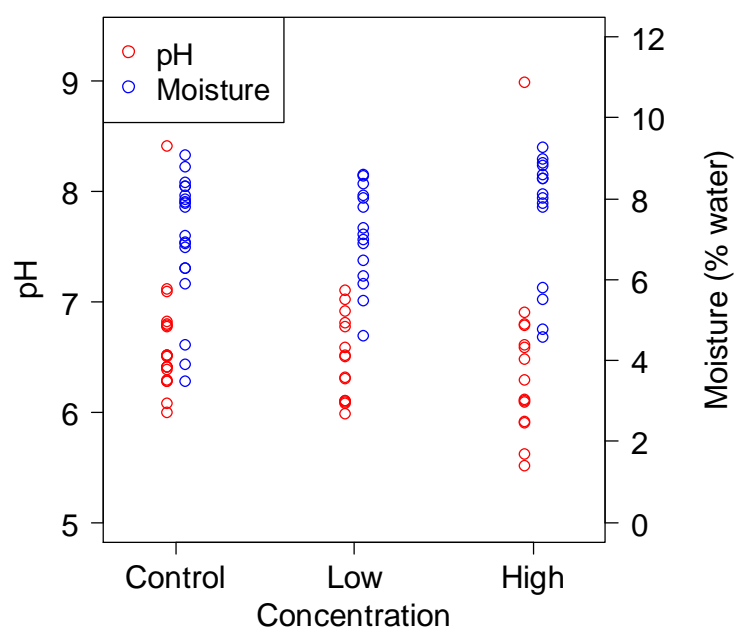

Figure 8 Soil pH and moisture (\% water) for plots at the site in response to the addition of (a) Phosphorous (b) Nitrogen. 
The addition of phosphate fertilizer to experimental plots had a statistically significant positive effect on soil phosphorous $\left(\mathrm{ug} / \mathrm{ml}\right.$ ) levels $\left(t_{7}=0.81, p<0.001\right)$. This effect is illustrated in Figure 9a where soil phosphorous (ug/ml) levels increase with increasing concentration of phosphate fertilizer addition.

The addition of nitrate fertilizer to experimental plots did not have a statistically significant effect on soil nitrogen (\% w/w) levels, illustrated in Figure $9 b$.

(a) Phosphorous

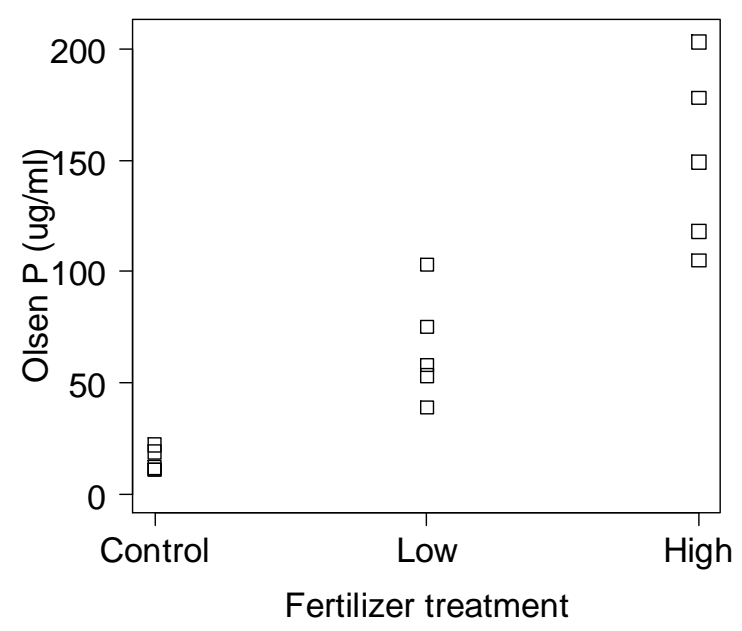

(b) Nitrogen

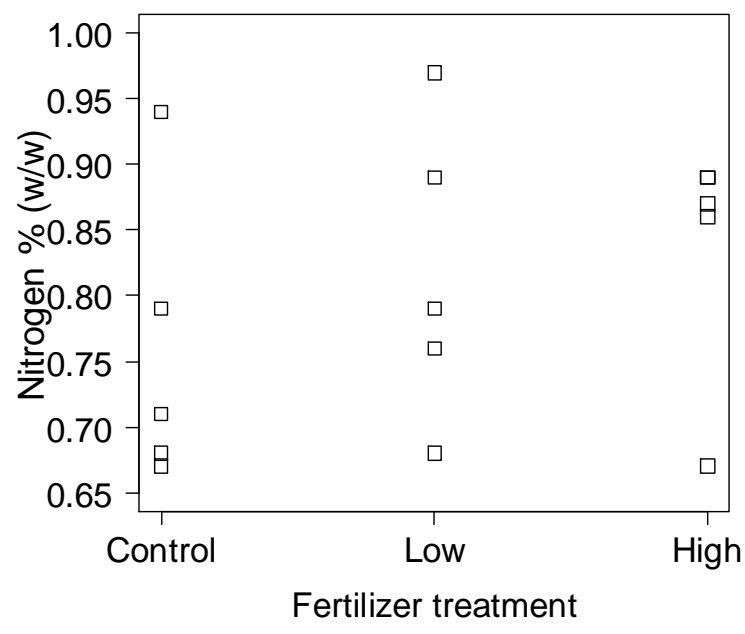

Figure 9 (a) Soil phosphorous (ug/ml) concentration and (b) Soil nitrogen (\% w/w) concentration of selected plots ( $n=5$, one per block) in response to fertiliser addition. 
Fertilizer addition did not have a statistically significant effect on soil carbon (\% w/w) or soil nitrogen $(\% \mathrm{w} / \mathrm{w})$ levels in experimental plots at the site, as illustrated in Figure 10a.

Fertilizer addition did not have a statistically significant effect on the soil carbon: nitrogen ratio $(\% \mathrm{w} / \mathrm{w})$ in the soil, as illustrated in Figure $10 \mathrm{~b}$.

(a)

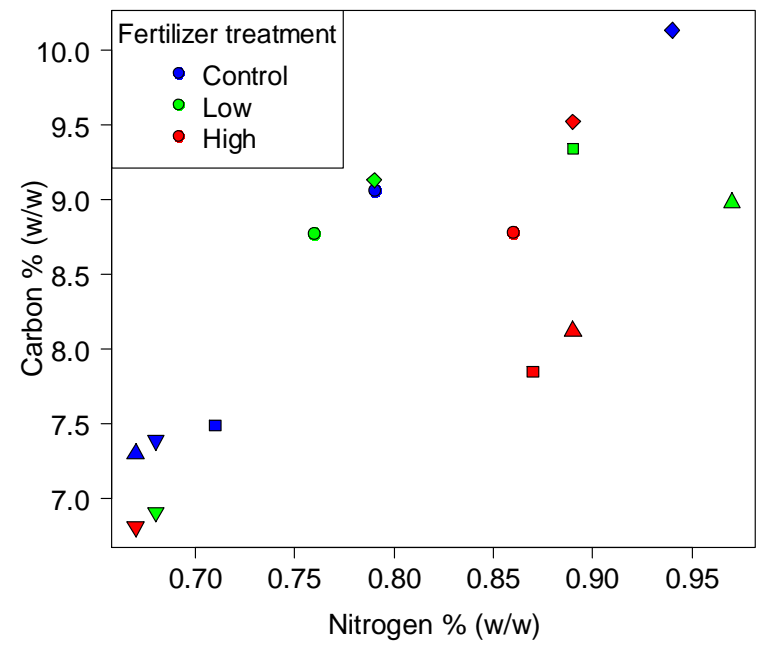

(b)

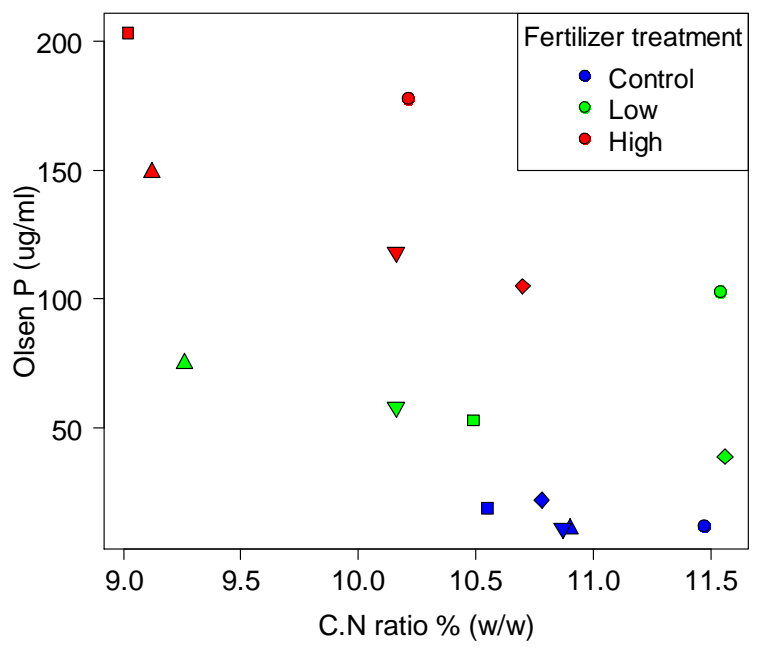

Figure $10(a)$ Soil carbon $(\% w / w)$ and nitrogen $(\% w / w)$ levels in selected plots at the site in response to fertilizer treatments. (b) Soil carbon-nitrogen (\% w/w) and phosphorous (ug/ml) levels in selected plots at the site in response to fertilizer treatments. The five different shape symbols correspond to the 5 different experimental blocks at the site. 


\subsubsection{Plant community structure}

A total of 15 plant species were recorded in plots at the site over the study period (Appendix 2.6.5). The principal species recorded at the site were the introduced grasses: Agrostis capillaris, Glyceria fluitans and Agrostis stolonifera, also the herbaceous plants; Galium palustre, and Leontodon autuminalis, and the native sedge; Isolepis prolifera.

The general seasonal trends in species abundance over the experimental period at the site are shown in Figure 11 and Table 6. Agrostis capillaris, A. stolonifera and G. fluitans maintained dominant plant cover of between $73 \%$ and $78 \%$ at the site. The abundance of the common weed Schedonorus arundinaceus increased by $1.8 \%$ plant cover and from occupying 6 plots to 20 plots over the experimental period. Abundance of the introduced dicotyledonous herb G. palustre decreased by $14.5 \%$ plant cover and Leontodon autumninalis increased by $3.4 \%$ plant cover over the experimental period. The small native sedge Eleocharis acuta increased in abundance from occupying zero plots in December to 16 plots in May.

Figure 12 shows that the native sedge I. prolifera had a statistically significant increase in plant cover of $2.8 \%$ over the study period in response to nitrogen addition $\left(t_{42}=2.21, p<\right.$ 0.05). However, this effect was non-significant under the Holm-Bonferroni method which aims to control the Familywise error rate. 


\section{Control}

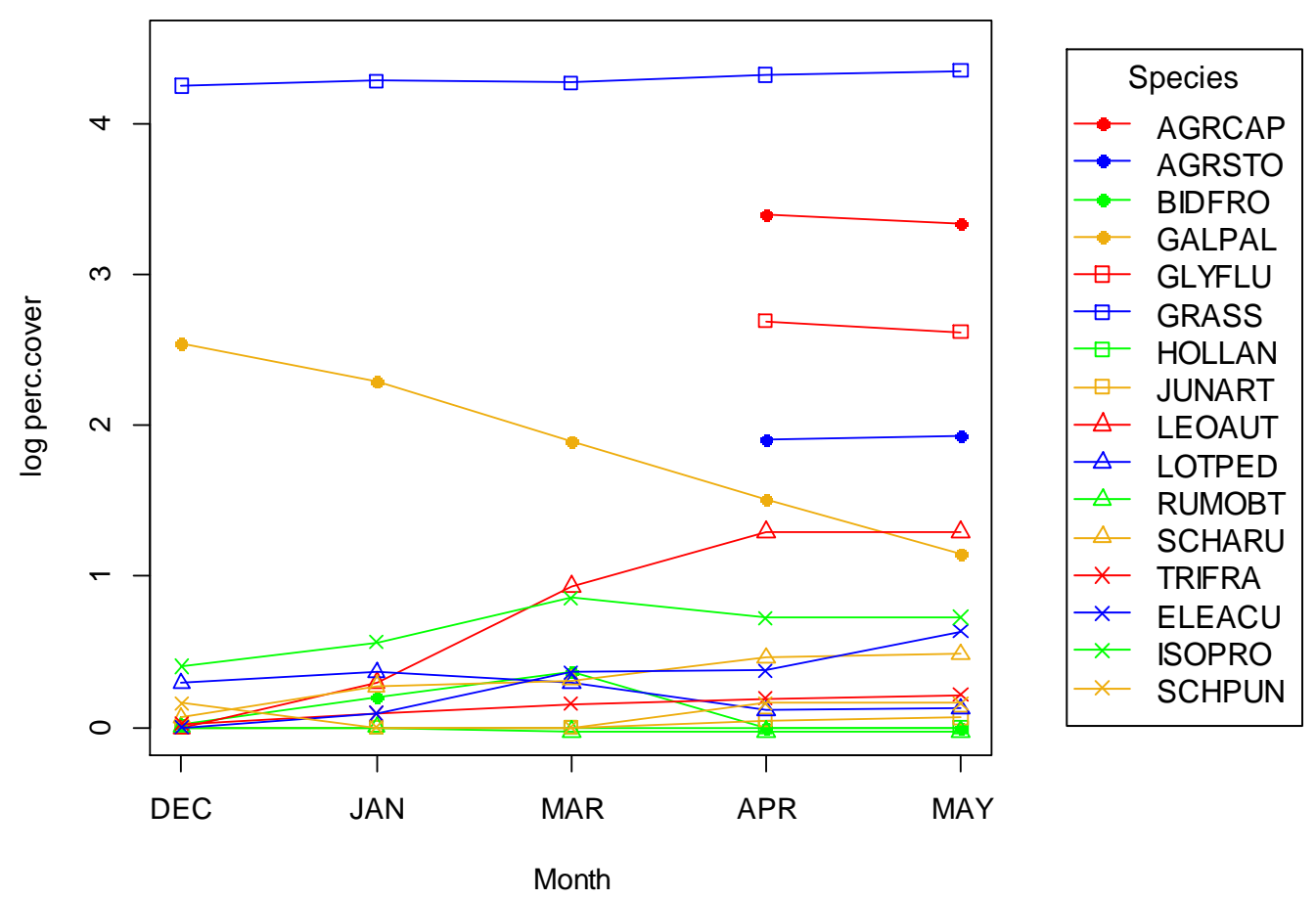

Figure 11 Change in log percent cover of plant species recorded at each data collection time (December - May) for the control treatment (no fertiliser added). Species are coded with 6 letters (GENUS.SPECIES). GRASS is a combination of $A$. capillaris, $A$. stolonifera, and $G$. fluitans. Individual recordings of $A$. capillaris, $A$. stolonifera, and $G$. fluitans only took place in April and May. Plant codes are listed in Appendix 2.6.5. 
Table 6 Species abundance (average percent cover) and number of plots occupied in December and May within 50 plots at Stage 2, Wairio Wetland. Grass species is a combination of $A$. capillaris, $A$. stolonifera, and G. fluitans. Individual measurements of $A$. capillaris, A. stolonifera, and G. fluitans were not recorded in December.

\begin{tabular}{lcccc}
\hline \multicolumn{1}{c}{ Species } & \multicolumn{2}{c}{ December } & \multicolumn{2}{c}{ May } \\
\cline { 2 - 5 } & $\begin{array}{c}\text { Abundance } \\
\text { (\% cover) }\end{array}$ & $\begin{array}{c}\text { Number of } \\
\text { plots } \\
\text { occupied }\end{array}$ & $\begin{array}{c}\text { Abundance } \\
\text { (\% cover) }\end{array}$ & $\begin{array}{c}\text { Number of } \\
\text { plots } \\
\text { occupied }\end{array}$ \\
\hline Agrostis capillaris & NA & NA & 31.1 & 49 \\
Agrostis stolonifera & NA & NA & 19.9 & 36 \\
Bidens frondosa & 0.4 & 4 & 0 & 0 \\
Eleacharis acuta & 0 & 0 & 2.8 & 16 \\
Galium palustre & 17.6 & 47 & 3.1 & 31 \\
Glyceria fluitans & NA & NA & 26.7 & 44 \\
Grass & 73.8 & 50 & 77.9 & 50 \\
Holcus lanatus & 0.1 & 1 & 0.4 & 3 \\
Isolepis prolifera & 4.5 & 21 & 7.3 & 28 \\
Juncus articulatus & 0 & 0 & 0.5 & 14 \\
Leontodon autumninalis & 0.8 & 16 & 4.2 & 14 \\
Lotus pedunculatus & 1.8 & 8 & 0.7 & 12 \\
Rumex obtusifolius & 0.4 & 4 & 0.2 & 4 \\
Schedonorous & 0.5 & 6 & 2.3 & 20 \\
arundinaceus & 0.1 & 1 & 0.6 & 3 \\
Schoenoplectus pungens & 0.1 & 3 & 0.7 & 8 \\
Trifolium fragiferum & & & & \\
\hline & 0.1 & & & 3 \\
\hline
\end{tabular}


(a) High phosphorous

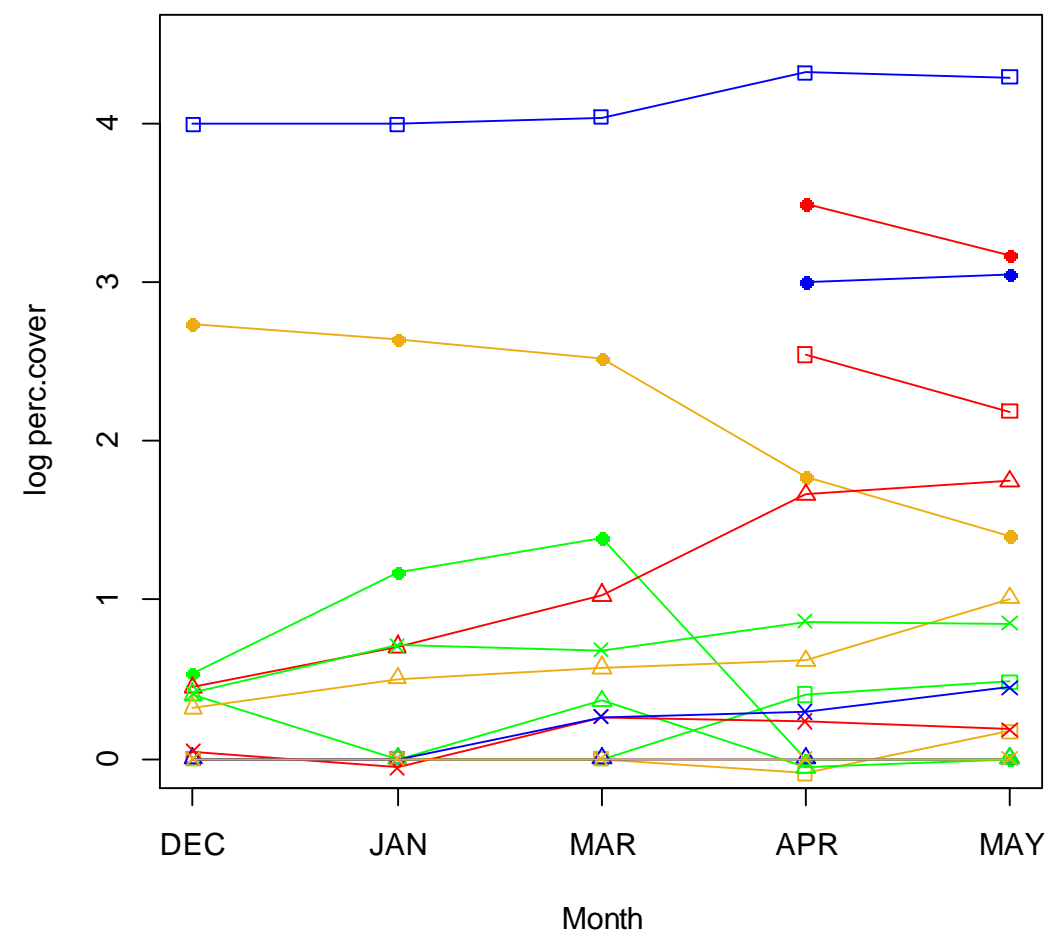

(b) High nitrogen

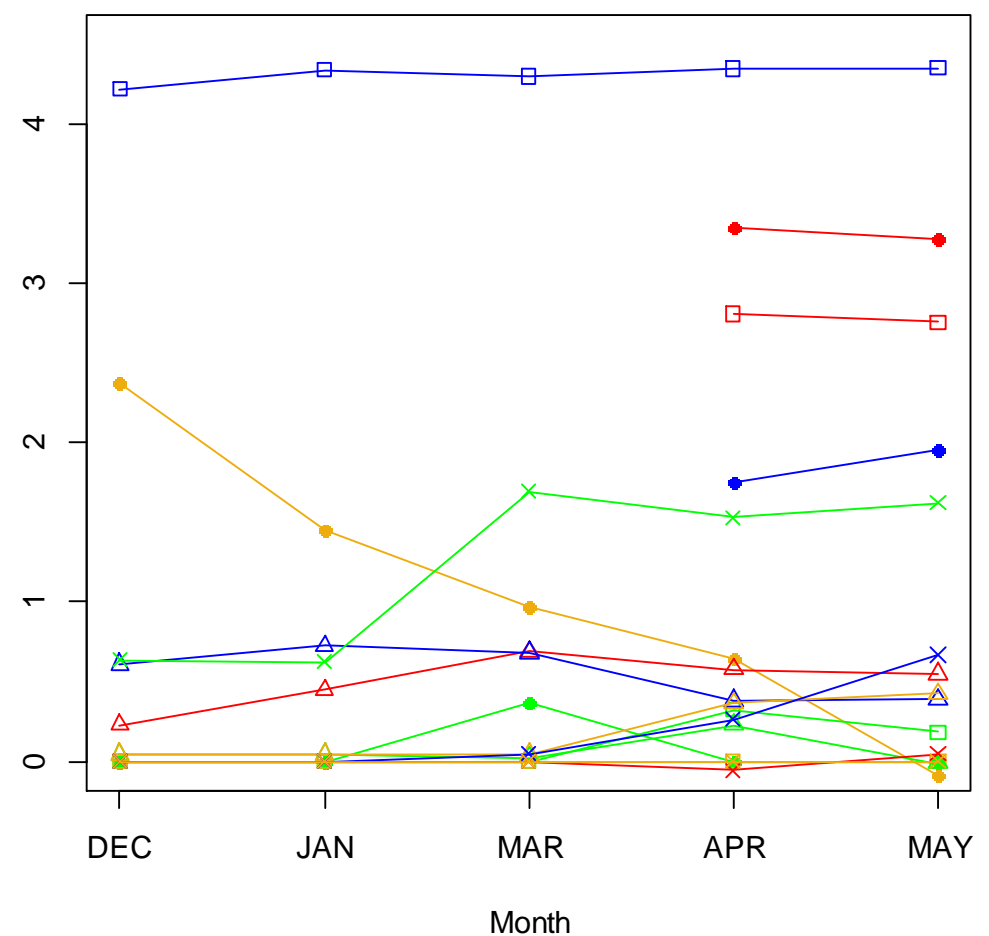

Species

AGRCAP

AGRSTO

BIDFRO

GALPAL

GLYFLU

GRASS

HOLLAN

JUNART

LEOAUT

LOTPED

RUMOBT

- SCHARU

TRIFRA

ELEACU

ISOPRO

SCHPUN

Figure 12 Change in log percent cover of plant species recorded at each data collection time (December - May) for the (a) high phosphorous treatment and (b) high nitrogen treatment. Species are coded with 6 letters (GENUS.SPECIES). GRASS is a combination of $A$. capillaris, $A$. stolonifera, and G. fluitans. Individual recordings of A. capillaris, A. stolonifera, and G. fluitans only took place in April and May. Plant codes are listed in Appendix 2.6.5. 
Figure 13a of the PCoA plot overlaid with contours of phosphorous fertiliser addition shows an even distribution of species communities across phosphorous levels. Figure $13 \mathrm{~b}$ of the PCoA plot overlaid with contours of nitrogen fertiliser addition shows species communities with high nitrogen addition grouping together. Figure 14a, a PCoA plot of the change in species abundance in plots at the site in response to phosphorous fertiliser addition, suggests plant communities in plots at the site are not responding to phosphorous addition as they are dissimilar (spread out over the matrix). Figure 14b, a PCoA plot of nitrogen fertiliser addition, suggests that the plant communities in high concentration plots may have become more similar over the experimental period with apparent clustering of these plots in the matrix. 
(a) Phosphorous

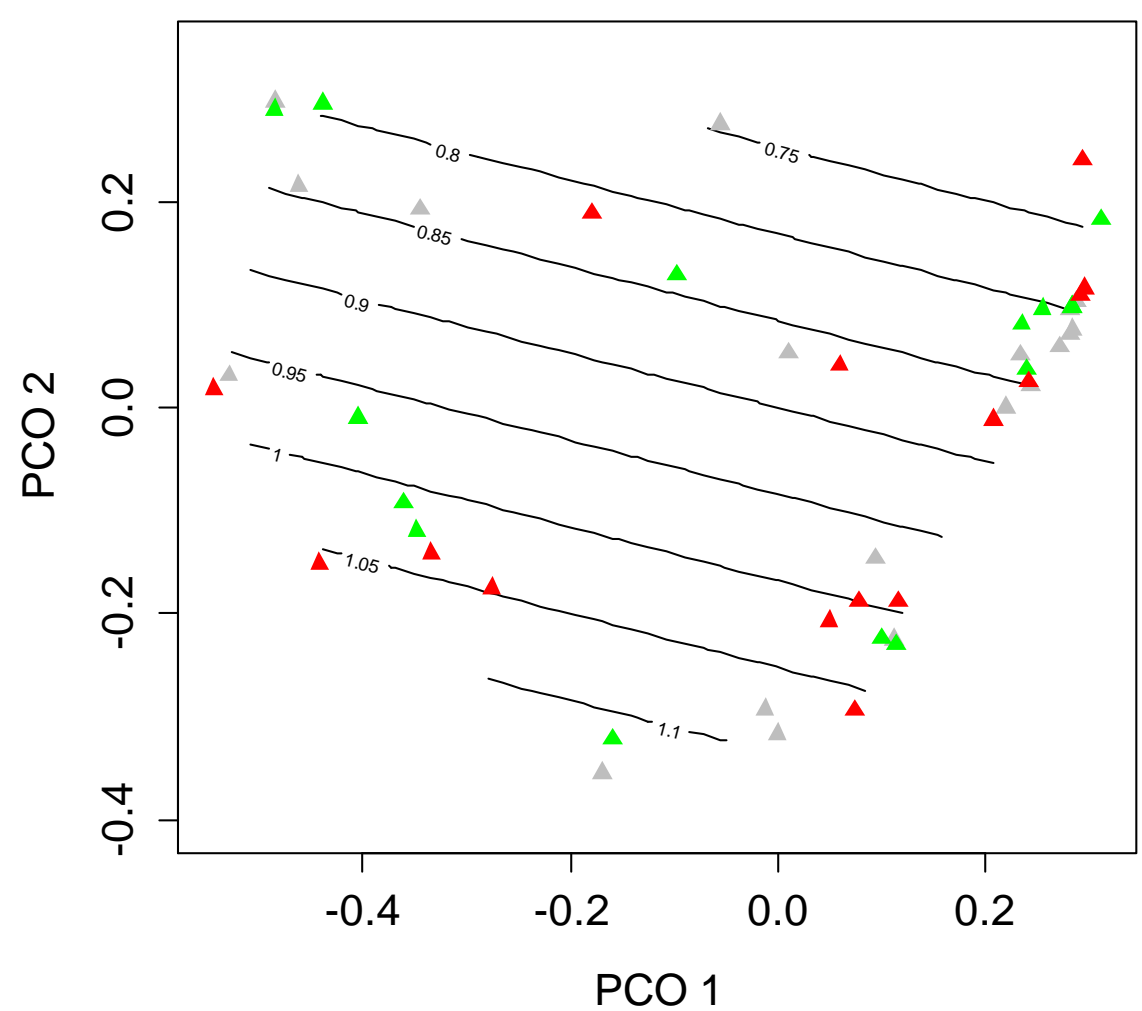

(b) Nitrogen

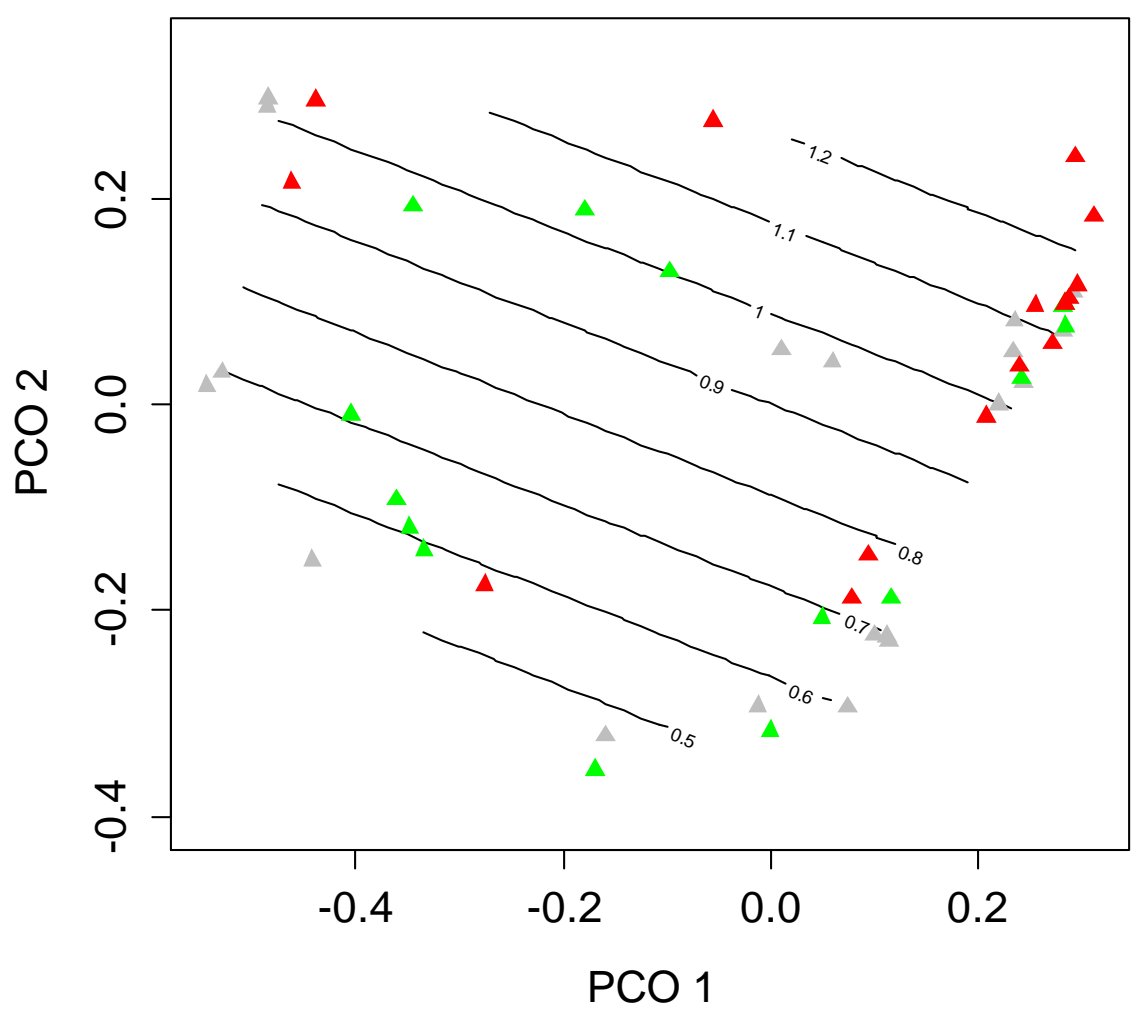

Figure 13 Principle co-ordinate analysis (PCOA) plot of the change in species abundance in the 50 plots from December to May overlaid with a fitted surface of contours of nutrient application for (a) Phosphorous (proportion of deviance $=0.0188$ ), (b) Nitrogen (proportion of deviance $=$ 0.0811). Nutrient contours are black lines. High nutrient plots = red triangles, low nutrient plots = green triangles, control plots = grey triangles. Rare species were excluded. 
(a) Phosphorous

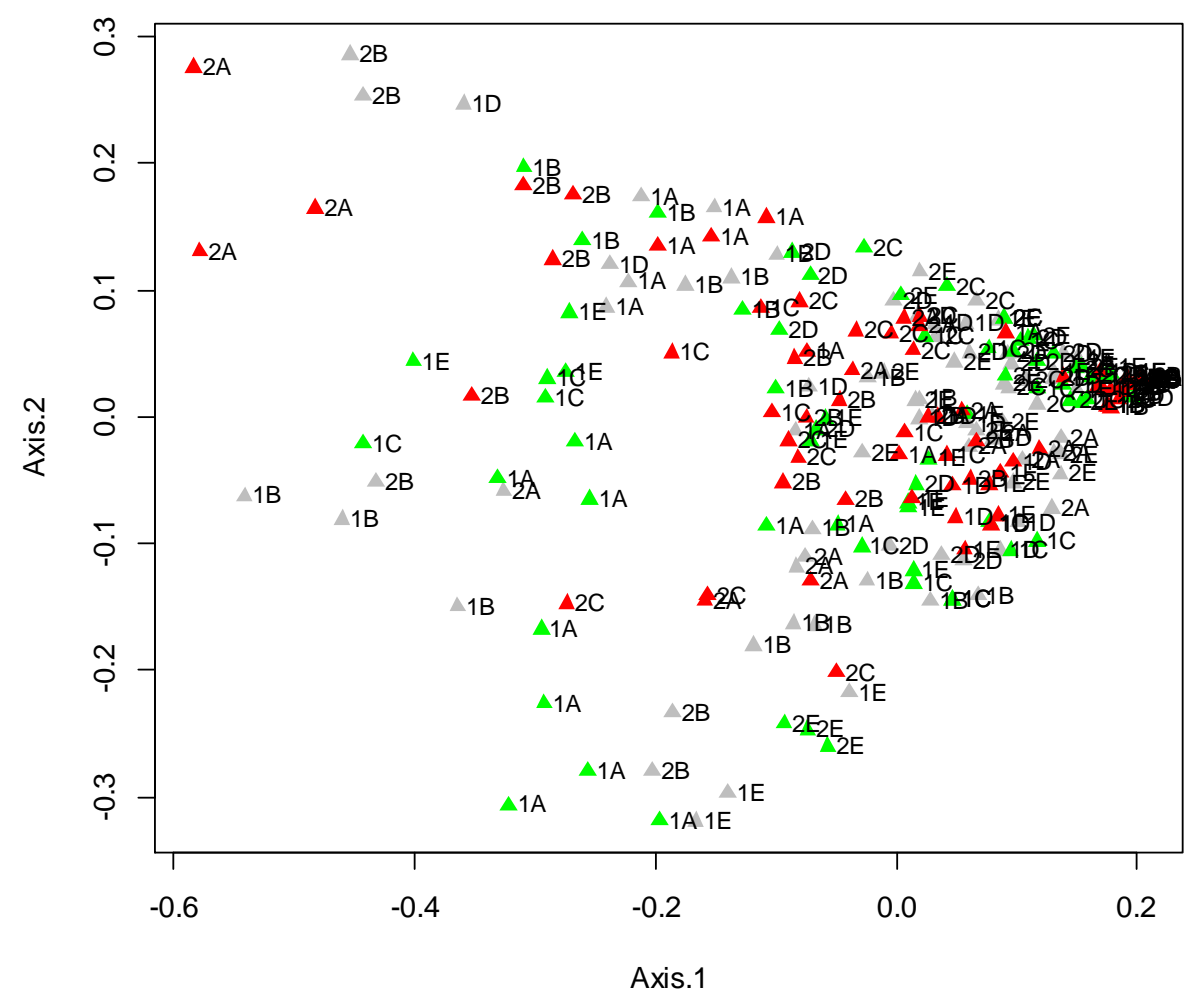

(b) Nitrogen

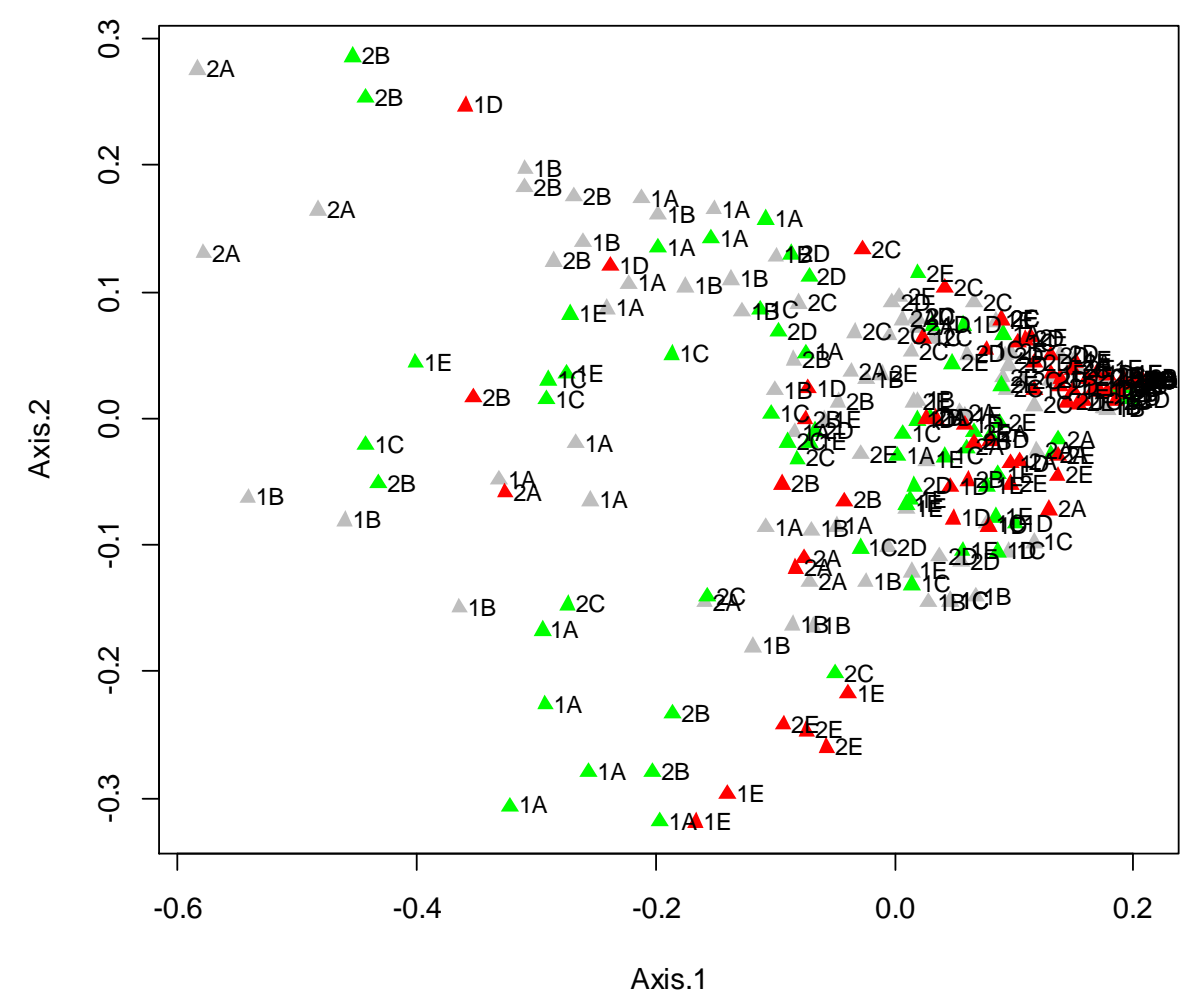

Figure 14 PCoA plot of the relative change in abundance of species in plots at the site from December to May in response to (a) phosphorous, and (b) nitrogen addition. Plots are labelled 1A-2E within each block. Triangles represent the nutrient concentrations; grey = control, green = low, red $=$ high . 


\subsubsection{Plant community biomass}

All $p$-values calculated in the linear mixed effects model of the change in species biomass in response to fertiliser concentration shown in Table 7 are deemed non-significant under the Holm-Bonferroni method which aims to control the Familywise error rate. Under this method only $p$-values $<0.005$ would be deemed significant (significant $p$-value $=0.05 / 11$ species).

Table 7 shows that nitrogen addition to experimental plots had a positive effect on the change in biomass (percent cover $\mathrm{x}$ average height) of the native species Isolepis prolifera $\left(t_{42}=2.28, p<0.05\right)$, but this was not statistically significant under Holm-Bonferroni method. Figure 15 suggests high levels of nitrogen fertiliser in association with low levels of phosphorous fertiliser addition promoted an increase in biomass of $I$. prolifera over the study period.

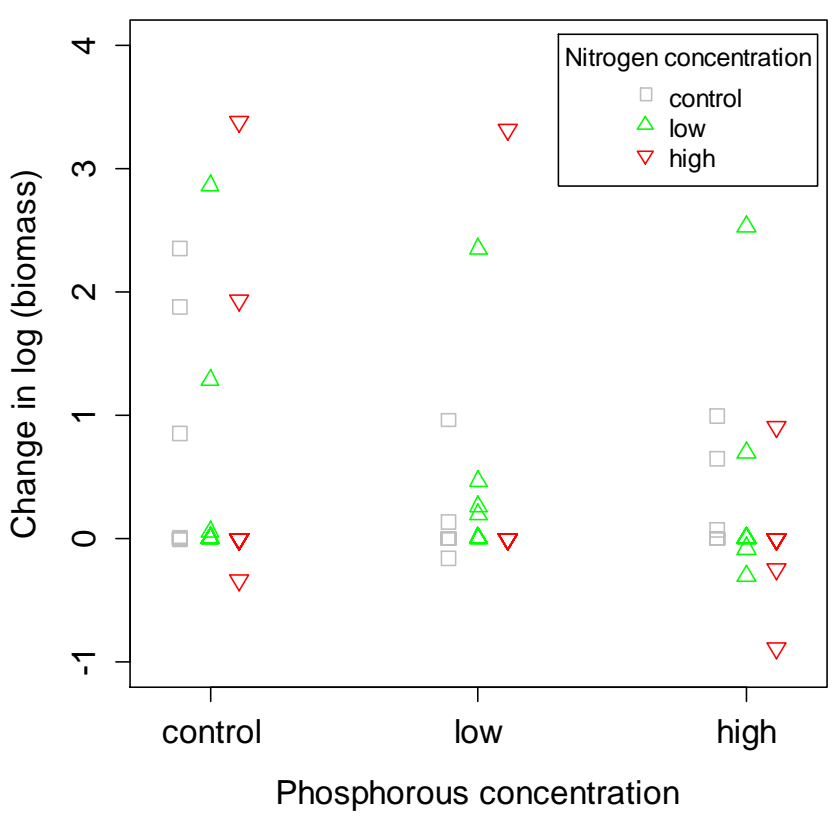

Figure 15 Scatterplot of change in log (biomass) of $I$. prolifera from December to May in response to phosphorous and nitrogen fertiliser concentrations in plots (control, low, high). 
Table 7 Linear mixed effects model of the relationship between the change in individual plant species biomass (\% cover $x$ average height) over the experimental period and the addition of phosphorous and nitrogen. Grass species is a combination of A. capillaris, $A$. stolonifera, and G. fluitans. Rare species recorded in 5 plots or less were excluded. indicates a significant p-value: ${ }^{*}<0.05, * *<0.01, * * *<0.001$.

\begin{tabular}{|c|c|c|c|c|c|c|}
\hline \multirow[t]{3}{*}{ Species } & \multicolumn{6}{|c|}{ Nutrient effect } \\
\hline & \multicolumn{2}{|c|}{ Nitrogen } & \multicolumn{2}{|c|}{ Phosphorous } & \multicolumn{2}{|c|}{ Nitrogen x Phosphorous } \\
\hline & Beta coeff. & p-value & Beta coeff. & p-value & Beta coeff. & p-value \\
\hline \multicolumn{7}{|l|}{ Introduced } \\
\hline Agrostis capillaris & -1.611 & 0.9829 & -35.246 & 0.6394 & 51.423 & 0.4078 \\
\hline Agrostis stolonifera & -24.521 & 0.7123 & -11.290 & 0.8651 & -16.187 & 0.7675 \\
\hline Galium palustre & 1.263 & 0.9909 & -81.570 & 0.4641 & 76.4047 & 0.4055 \\
\hline Glyceria fluitans & 85.482 & 0.4075 & 148.003 & 0.1549 & -98.139 & 0.2501 \\
\hline Grass & -126.226 & 0.5467 & 249.220 & 0.2369 & -156.130 & 0.3666 \\
\hline Juncus articulatus & -0.769 & 0.8265 & 0.658 & 0.8513 & -0.538 & 0.8522 \\
\hline Leontodon autumninalis & -40.350 & 0.3137 & 5.646 & 0.8872 & -10.627 & 0.7460 \\
\hline Lotus pedunculatus & -23.528 & 0.0982 & -3.583 & 0.7980 & 13.960 & 0.2298 \\
\hline Schedonorus arundinaceus & 21.934 & 0.5142 & 42.771 & 0.2066 & -44.373 & 0.1136 \\
\hline Trifolium fragiferum & -11.754 & 0.2834 & -3.316 & 0.7607 & 1.865 & 0.8352 \\
\hline \multicolumn{7}{|l|}{ Native } \\
\hline Eleacharis acuta & -66.756 & 0.4011 & -50.402 & 0.5254 & 117.085 & 0.0780 \\
\hline Isolepis prolifera & 217.982 & $0.0277^{*}$ & 33.208 & 0.7299 & -98.727 & 0.2166 \\
\hline Total & 31.146 & 6.1051 & 294.099 & 7.1195 & -163.983 & 5.2689 \\
\hline
\end{tabular}




\subsubsection{Changes in plant community diversity}

Changes in plant community diversity at the site were obtained using the Shannon Wiener Index of Diversity. Table 8 shows that the diversity in the plant community at Wairio Wetland increased in 'control' and 'nitrogen and phosphorous' plots, however this effect was not statistically significant $(p>0.1)$. Plant community diversity decreased in plots at the site with either the addition of nitrogen or phosphorous, however this effect was not statistically significant $(p>0.1)$.

Table 8 Linear mixed effects model showing the effect of fertiliser on changes in the Shannon Wiener diversity index of the plant community from December to May within plots at the site.

\begin{tabular}{lccccc}
\hline Fertiliser & Beta & Std. error & df & $\mathbf{t}$ & $\mathbf{P}$ \\
\hline $\begin{array}{l}\text { Intercept } \\
\text { (control) }\end{array}$ & 0.1518 & 0.0933 & 42 & 1.628 & 0.111 \\
$\mathbf{N}$ & -0.0501 & 0.0701 & 42 & -0.715 & 0.479 \\
$\mathbf{P}$ & -0.0504 & 0.0701 & 42 & -0.719 & 0.476 \\
$\mathbf{N}$ x P & 0.0296 & 0.0577 & 42 & 0.514 & 0.610 \\
\hline
\end{tabular}




\subsection{Discussion}

Phosphate and nitrate fertiliser addition had neither a statistically significant positive nor negative effect on the biomass, diversity and structure of the plant community at Wairio Wetland. Fifteen plant species were recorded in plots at Wairio over the five month experimental period, with considerable seasonal changes in species densities at the site noted but few changes in overall community structure. It has been suggested that common introduced plants respond positively to fertiliser application and can outcompete rare native plants promoting a homogenous community. A study by Hautier et al. (2009) found invasive species respond positively to nutrient addition increasing their growth and becoming more competitive in environments, whereas Houlahan et al. (2006) found rare species respond negatively to nutrient addition due to greater competition with invasive weeds and higher sensitivity to changes in soil nutrient levels. Invasive weed species are characterised by a high competitive ability, fast growth, and resilience to low resource levels in degraded systems (Stinson et al. 2006). In this case I would have expected to observe increases in densities of the common pest weeds; S. arundinaceus, B. frondosa, $H$. lanatus, and $R$. obtusifolius (Champion 1998; Danuso et al. 2012; Groves 1999; Zaller 2004), and strong competitors; A. capillaris and A. stolonifera (Lenssen et al. 2004; Timmins \& Mackenzie 1995), in response to nutrient addition. Conversely I would have expected reductions in densities of the native species; S. pungens and I. prolifera (Albert et al. 2013; NZPCN 2013) and the small rare native species; E. acuta at the site (Champion 1998).

However, results from the linear mixed effects models showed no significant changes in species cover at Wairio Wetland in response to fertiliser addition, with the exception of $I$. prolifera that responded positively to nitrogen addition. This result can be expected as $I$. prolifera is found to grow prolifically in eutrophic waters throughout New Zealand (NZPCN 2013). However under Holm-Bonferroni method which aims to control the family-wise error rate this effect was deemed insignificant. Results from the Principle Co-ordinate analyses suggest species composition within high nitrogen plots at the site are becoming similar suggesting preliminary evidence of homogeneity at the site, but this effect is not statistically significant. These results contrast studies by Tyler et al. (2007) in a San Francisco Bay estuary, Pekin et al. (2012) in South West Australia and Dawson (2012) in a nursery in 
Switzerland where fast growing common species increased at the site becoming the dominant competitor, leading to reductions in the rare native species.

The addition of phosphate or nitrate fertiliser to experimental plots had no apparent effect on the biomass of the 15 plant species recorded at Wairio. Primarily nitrogen (Iverson et al. 2010; Vitousek \& Howarth 1991; Vance 2001; Vymazal et al. 2008) and secondarily phosphorous (Bedford et al. 1999; Holford 1997) are commonly limited nutrients in wetland ecosystems worldwide. Nitrogen is an essential nutrient that helps stimulate above-ground biomass in plants (Leyshon 1991) whereas phosphorous is an essential nutrient required for root development and growth (Rooney \& Clipson 2009). There is evidence from other studies that I. prolifera, S. arundinaceus, R. obtusifolius, A. capillaris and G. fluitans, which are present in experimental plots at Wairio, respond positively to high levels of nutrient addition by increasing growth or tolerating the new conditions (Goodwin et al. 1998; Jeangros \& Nösberger 1990; NZPCN 2013; Timmins \& Mackenzie 1995). Consequently, I predicted that the addition of either nitrogen or phosphorous would lead to a significant increase in the biomass of these particular plant species and possibly other species at Wairio. Results from the linear mixed effects models, found no statistically significant changes in species biomass in response to nutrient addition with the exception of I. prolifera that had a positive response to nitrogen addition. However, under the Holm-Bonferroni method this response would be deemed insignificant. These results differ from studies which have reported increases in growth by up to $50 \%$ and overall increases in biomass of various plant communities associated with the addition of either nitrate (Dougherty et al. 1990; Gough et al 2000; Leyshon 1991), phosphate (Rooney \& Clipson 2009) or both nitrate and phosphate fertiliser (Iverson et al. 2010; Maurer and Zedler 2002). In contrast excess soil macro-nutrient levels from over-enrichment can result in growth retardation or death of plants. A study by Kneitel \& Lessin (2010) in California vernal pools found a reduction in plant cover associated with the addition of nitrate and phosphate fertiliser linked to excess nutrient levels in the soil. Excessive soil nitrogen levels can result in plant dehydration with leaf burning and damage from associated increases in soil salt mineral concentrations (Andrews 1998), stunted root growth and susceptibility to disease and insects (Daane et al. 1995; Dise et al. 2011), while excess soil phosphorous levels can result in reductions in 
important micro-nutrients in the soil (Dougherty et al. 1990), leaf chlorosis and reductions in associated plant mycorrhizal fungi (Grant et al. 2005). Lotus pedunculatus, a nitrogen fixing legume present at the site, can only tolerate low soil nutrient levels (Lambert et al. 1986; NZPCN 2013), so I would expect to it to be negatively impacted by nutrient addition however this effect was not found in my experiment.

The unexpected results could be linked to the experimental methods adopted or site characteristics. Changes in above-ground biomass of species were recorded at the site during the experiment in the form of percent cover and average height of respective species, whereas below-ground biomass, particularly root development, which is very sensitive to changes in nutrient levels (López-Bucio et al. 2003) was not measured. The duration of the experiment (five months) may also have proven too short a time to show considerable changes in above-ground biomass of plant species at the site in response to nutrient addition with changes in below-ground biomass more likely. However, the studies I have reported have noted significant changes in plant biomass from fertiliser addition in both short-term studies; between two to six months long (Kneitel \& Lessin 2010; Maurer \& Zedler 2002; Rooney \& Clipson 2009) and long-term studies; between four to nine years long (Gough et al. 2000; Iverson et al. 2010; Leyshon 1991), suggesting that responses can vary between species, ecosystems and their environmental conditions.

There is a theory that plant productivity only increases following the addition of the limiting nutrients in that environment (Ceulemans et al. 2012). This leads us to believe that Wairio is neither phosphorous nor nitrogen limited as plant species at the site did not respond positively to increases in these nutrients from fertiliser addition. A study undertaken by Marcar et al. (2000) corroborates these findings in that fertiliser addition in saline seeps resulted in no change in plant growth or biomass with adequate soil nutrient levels already at the site. Plant communities in environments with deficient nutrient levels could improve growth and survival with nutrient loading however in areas with excess or adequate nutrient levels nutrient loading could be detrimental or have no effect on plant growth and survival (Grattan \& Grieve 1992). High nutrient levels are common in aquatic habitats (Camaro \& Alonso 2006). Wairio Wetland is linked to the supertrophic Lake Wairarapa by 
surface water flows and the site of the experiment was used as cattle pasture up until 2007 when it was fenced off. Livestock manure and eutrophic waters can contribute to high soil phosphorous and nitrogen levels (Grant et al. 2005; Reeves \& Champion 2004) therefore there is a high probability that soils at the site may already have an abundant or excess supply of macronutrients and that fertiliser application may have proved insignificant to plant species.

The addition of phosphate or nitrate fertiliser to experimental plots had no statistically significant effect on the plant community diversity at Wairio. Changes in biodiversity of plant communities are commonly attributed to changes in soil nitrogen, phosphorous and carbon levels, air temperature, precipitation and hydrology at a site (Porter et al. 2013). Studies by Harpole \& Tilman (2007) at Sedgwick Reserve California, Green \& Galatowitsch (2002) in created wetlands in Minnesota and Stevens et al. (2004) in grasslands in Great Britain have reported reductions in overall plant biodiversity from the addition of phosphate and nitrate fertiliser. Therefore I initially hypothesized that nitrogen and phosphorous addition to experimental plots at Wairio would result in a reduction in overall plant biodiversity however this was not the case. The results, although not statistically significant, suggest that the plant community at Wairio was exhibiting early stages of the effects of nutrients, with a decrease in diversity with the addition of either phosphate or nitrate, and increase in diversity with the addition of both. There is the possibility that high levels of phosphorous in the soil led to an increase in nitrogen uptake efficiency hence the positive response in plant diversity, even though there is evidence that high concentrations of both can result in phosphorous limiting plant production (Dougherty et al. 1990).

I propose that the short duration of the experiment and extreme weather conditions experienced could have contributed to these unexpected results. A Drought (worst in 70 years for NZ) was experienced during the experimental period with low rainfall and high sunshine hours, particularly between December 2012 and March 2013 that could have led to intense water stress in certain species. Hydraulic failure from reductions in soil moisture, high evaporation rates, and possible carbon starvation is common in plants during long and intense droughts (McDowell et al. 2008). Species not adapted to withstand drought 
conditions or those already stressed could have succumbed to death resulting in changes in plant diversity not linked to nutrient levels.

I conclude that continuation of this experiment is necessary to assess the long-term effects nitrogen and phosphorous fertiliser application may have on the plant community at Wairio Wetland. The results from this experiment are not definitive enough to further suggest management actions undertaken by the Wairio Wetland Restoration Committee. At this stage, I advise that the committee's plan, to divert potentially nutrient rich water through Wairio Wetland, proceeds with caution until further evidence is gained on the effects nutrient rich water may have on the established plant community. 


\subsection{References}

Albert DA, Cox DT, Lemein T, Yoon H-D 2013. Characterization of Schoenoplectus pungens in a Great Lakes Coastal Wetland and a Pacific Northwestern Estuary. Wetlands 33(3): 445-458.

Andrews G 1998. Gardening and Water Quality Protection: Understanding Nitrogen Fertilisers. Oregon, Oregon State University. 44 p.

Angeloni NL, Jankowski KJ, Tuchman NC, Kelly JJ 2006.Effects of an invasive cattail species (Typha $\mathrm{x}$ glauca) on sediment nitrogen and microbial community composition in a freshwater wetland. FEMS Microbiology Letters 263: 86-92.

Bedford BL, Walbridge MR, Aldous A 1999. Patterns in nutrient availability and plant diversity of temperate North American wetlands. Ecology 80: 2151-2169.

Bennett EM, Carpenter SR, Caraco NF 2001. Human Impact on Erodable Phosphorus and Eutrophication: A Global Perspective. Bioscience 51(3): 227- 234.

Boers AM, Frieswyk CB, Verhoeven JTA, Zedler JB 2006. Contrasting Approaches to the Restoration of Diverse Vegetation in Herbaceous Wetlands. In: Bobbink R, Beltman B, Verhoeven JTA, Whigham DF eds. Wetlands: Functioning, Biodiversity Conservation, and Restoration. New York, Springer. 315 p.

Brauer VS, Stomp M, Huisman J 2012. The Nutrient-Load Hypothesis: Patterns of Resource Limitation and Community Structure Driven by Competition for Nutrients and Light. The American Naturalist 179(6): 721-740.

Brooks ML 2003. Effects of increased soil nitrogen on the dominance of alien annual plants in the Mojave Desert. Journal of Applied Ecology 40(2): 344-353. 
Camaro JA, Alonso I 2006. Ecological and toxicological effects of inorganic nitrogen pollution in aquatic ecosystems: a global assessment. Environmental International 32: 831849.

Carpenter SR 2005. Eutrophication of aquatic ecosystems: Bistability and soil phosphorus. Proceedings of the National Academy of Sciences of the United States of America 102(29): 10002-10005.

Carpenter SR, Caraco NF, Correll DL, Howarth RW, Sharpley AN, Smith VH 1998. Nonpoint Pollution of Surface Waters with Phosphorus and Nitrogen. Ecological Applications 8(3): 559-568.

Ceulemans T, Merckx R, Hens M, Honnay O 2012. Plant species loss from European seminatural grasslands following nutrient enrichment - is it nitrogen or is it phosphorus?. Global Ecology and Biogeography 22: 73-82.

Champion PD 1998. Selective control of weeds in New Zealand wetlands. Procurements of the 51st N.Z. Plant Protection Conference, Hamilton, New Zealand. Pp. 251-254.

Chase JM, Knight TM 2006. Effects of eutrophication and snails on Eurasian Watermilfoil (Myriophyllum spicatum) invasion. Biological Invasions 8: 1643-1649.

Daane KM, Johnson RS, Michailides TJ, Crisosto CH, Dlott JW, Ramirez HT, Yokota G, Morgan DP 1995. Excess nitrogen raises nectarine susceptibility to disease and insects. California Agriculture 49(4): 13-18.

Danuso F, Zanin G, Sartorato I 2012. A modelling approach for evaluating phenology and adaptation of two congeneric weeds (Bidens frondosa and Bidens tripartita). Ecological Modelling 243: 33-41. 
Davis M, Meurk C 2001. Protecting and restoring our natural heritage - a practical guide. Wellington, Department of Conservation. $94 \mathrm{p}$.

Dawson W, Fisher M, van Kleunen M 2012. Common and rare plant species respond differently to fertilisation and competition, whether they are alien or native. Ecology Letters 15: 873-880.

Dise N, Ashmore M, Belyazid S, Bleeker A, Bobbink R, de Vries W, Erisman JW, Spranger T, Stevens CJ, van den Berg L 2011. Nitrogen as a threat to European terrestrial biodiversity. In: Sutton MA ed. The European nitrogen assessment. Cambridge, Cambridge University Press. Pp. 463-494.

Dougherty KM, Mendelssohn IA, Monteferrante FJ 1990. Effect of Nitrogen, Phosphorus and Potassium Additions on Plant Biomass and Soil Nutrient Content of a Swale Barrier Strand Community in Louisiana. Annals of Botany 66(3): 265-271.

Engelhardt KAM, Ritchie ME 2001. Effects of macrophyte species richness on wetland ecosystem functioning and services. Nature 411: 687-689.

Goodwin MJ, Parkinson RJ, Williams END, Tallowin JRB 1998. Soil phosphorus extractability and uptake in a Cirsio-Molinietum fen-meadow and an adjacent Holcus lanatus pasture on the culm measures, north Devon, UK. Agriculture, Ecosystems and Environment 70(2-3): 169-179.

Gottschall N, Boutin C, Crolla A, Kinsley C, Champagne P 2007. The role of plants in the removal of nutrients at a constructed wetland treating agricultural (dairy) wastewater, Ontario, Canada. Ecological Engineering 29(2): 154-163.

Gough L, Osenberg CW, Gross KL, Collins SL 2000. Fertilization effects on species density and primary productivity in herbaceous plant communities. Oikos 89: 428-439. 
Grant C, Bittman S, Montreal M, Plenchette C, Morel C 2005. Soil and fertilizer phosphorus: effects on plant P supply and mycorrhizal development. Canadian Journal of Plant Sciences 85: 3-14.

Grattan SR, Grieve CM 1992. Mineral element acquisition and growth response of plants grown in saline environments. Agriculture, Ecosystems \& Environment 38: 275-300.

Green EK, Galatowitsch SM 2002. Effects of Phalaris arundinacea and nitrate-N addition on the establishment of wetland plant communities. Journal of Applied Ecology 39(1): 134-144.

Grose PJ 2012. Restoring a seasonal wetland using woven black plastic weed mat to overcome a weed threshold. Ecological Management and Restoration 13(2): 191195.

Groves RH 1999. Environmental weed forum. Plant Protection Quarterly 14: 92-95.

Haddad NM, Crutsinger GM, Gross K, Haarstad J, Knops JMH, Tilman D 2009. Plant species loss decreases arthropod diversity and shifts trophic structure. Ecology Letters 12: 1029-1039.

Harper D 1992. Eutrophication of freshwaters: principles, problems and restoration. London, Chapman \& Hall. 327 p.

Harpole WS, Tilman D 2007. Grassland species loss resulting from reduced niche dimension. Nature 446: 791-793.

Hautier Y, Niklaus PA, Hector A 2009. Competition for Light Causes Plant Biodiversity Loss After Eutrophication. Science 324(5927): 636-638. 
Havens KE, James RT, East TL, Smith VH 2003. N: P ratios, light limitation, and cyanobacterial dominance in a subtropical lake impacted by non-point source nutrient pollution. Environmental Pollution 122: 379-390.

Holford ICR 1997. Soil phosphorus: its measurement and its uptake by plants. Australian Journal of Soil Research 35: 227-239.

Honsova D, Hejcman M, Klaudisova M, Pavlu V, Kocourkova D, Hakl J 2007. Species composition of an alluvial meadow after 40 years of applying nitrogen, phosphorus and potassium fertilizer. Preslia 79: 245-258.

Houlahan JE, Keddy PA, Makkay K, Findlay CS 2006. The effects of adjacent land use on wetland species richness and community composition. Wetlands 26(1): 79-96.

Iverson CM, Bridgham SD, Kellogg LE 2010. Scaling plant nitrogen use and uptake efficiencies in response to nutrient addition in peatlands. Ecology 91(3): 693-707.

Jeangros B, Nösberger J 1990. Effects of an established sward of Lolium perenne L. on the growth and development of Rumex obtusifolius L. seedlings. Grass and Forage Science 45: 1-7.

Keddy PA 2000. Wetland ecology: Principles and conservation. Cambridge, Cambridge University Press. 614 p.

Kneitel JM, Lessin CL 2010. Ecosystem-phase interactions: aquatic eutrophication decreases terrestrial plant diversity in California vernal pools. Oecologia 163: 461-469.

Lambert MG, Clark DA, Grant DA, Costall DA 1986. Influence of fertiliser and grazing management on North Island moist hill country. New Zealand Journal of Agricultural Research 29(1): 11-21. 
Lenssen JPM, van de Steeg HM, de Kroon H 2004. Does disturbance favour weak competitors?. Mechanisms of changing plant abundance after flooding. Journal of Vegetation Science 15: 303-312.

Leyshon AJ 1991. Effect of rate of nitrogen fertilizer on the above- and below-ground biomass of irrigated bromegrass in southwest Saskatchewan. Canadian Journal of Plant Science 71: 1057-1067.

López-Bucio J, Cruz-Ramírez A, Herrera-Estrella L 2003. The role of nutrient availability in regulating root architecture. Current Opinions in Plant Biology 6(3): 280-287.

Mahaney WM, Wardrop DH, Brooks RP 2004. Impacts of sedimentation and nitrogen enrichment on wetland plant community development. Plant Ecology 175(2): 227243.

Marcar NE, Hossain AKMA, Crawford DF, Nicholson AT 2000. Evaluation of tree establishment treatments on saline seeps near Wellington and Young in New South Wales. Australian Journal of Experimental Agriculture 40: 99-106.

Maurer DA, Zedler JB 2002. Differential invasion of a wetland grass explained by tests of nutrient and light availability on establishment and clonal growth. Oecologia 131: 279-288.

Nixon SW 1995. Coastal marine eutrophication: a definition, social causes, and future concerns. Ophelia 41: 199-219.

McDowell N, Pockman WT, Allen CD, Breshears DD, Cobb N, Kolb T, Plaut J, Sperry J, West A, Williams DG, Yepez EA 2008. Mechanisms of plant survival and mortality during drought: why do some plants survive while others succumb to drought?. New Phytologist 178(4): 719-739. 
Olde Venterink H 2011. Does phosphorous limitation promote species-rich plant communities?. Plant and Soil 345: 1-9.

Olde Venterink H, Davidsson TE, Kiehl K, Leonardson L 2002. Impact of drying and re-wetting on N, P and K dynamics in a wetland soil. Plant and Soil 243:119-130.

Pekin BK, Boer MM, Wittkuhn RS, Macfarlane C, Grierson PF 2012. Plant diversity is linked to nutrient limitation of dominant species in a world biodiversity hotspot. Journal of Vegetation Science 23(4): 745-754.

Pinheiro J, Bates D, DebRoy S, Sarkar D 2013. nlme: Linear and Nonlinear Mixed Effects Models. http://cran.r-project.org/web/packages/nlme/nlme.pdf. R package version 3.1-113.

Porter EM, Bowman WD, Clark CM, Compton JE, Pardo LH, Soong JL 2013. Interactive effects of anthropogenic nitrogen enrichment and climate change on terrestrial and aquatic biodiversity. Biogeochemistry 114(1-3): 93-120.

Reeves PN, Champion PD 2004. Effects of Livestock Grazing on Wetlands: Literature Review. Hamilton, National Institute of Water and Atmospheric Research Ltd. 38 p.

Rekolainen S, Ekholm P, Heathwaite L, Lehtoranta J, Uusitalo R 2006. Off-site Impacts of Erosion: Eutrophication as an Example. In: Boardman J, Poessen J eds. Soil Erosion in Europe. Chichester, John Wiley \& Sons Ltd. Pp. 775-789.

Roberts DW 2013. labdsv: Ordination and Multivariate Analysis for Ecology. http://cran.rproject.org/web/packages/labdsv/labdsv.pdf. R package version 1.6-1.

Rooney DC, Clipson NJW 2009. Phosphate Addition and Plant Species Alters Microbial Community Structure in Acidic Upland Grassland Soil. Microbial Ecology 57(1): 4-13. 
Rumbaugh MD, Pendery BM, James DW 1993. Variation in the salinity tolerance of strawberry clover (Trifolium fragiferum L.). Plant and Soil 153(2): 265-271.

Sánchez-Carrillo S, Angeler DG, Álvarez-Cobelas M, Sánchez-Andrés R 2011. Freshwater Wetland Eutrophication. In: Ansari AA, Gill SS, Lanza GR, Rast W eds. Eutrophication: causes, consequences and control. Netherlands, Springer. Pp. 195210.

Scheffer M, Carpenter S, Foley JA, Folke C, Walker B 2001. Catastrophic shifts in ecosystems. Nature 413: 591-596.

Schindler DW 2006. Recent advances in the understanding and management of eutrophication. Limnology \& Oceanography 51: 356-363.

Smith RGB, Brock MA 1998. Germination potential, growth patterns and reproductive effort of Juncus articulatus and Glyceria australis in temporary shallow wetlands in Australia. Wetlands Ecology and Management 5: 203-214.

Smith VH 1998. Cultural eutrophication of inland, estuarine, and coastal waters. In: Pace ML, Groman PM eds. Successes, Limitations and Frontiers in Ecosystem Science. New York, Springer. 49 p.

Smith VH 2003. Eutrophication of Freshwater and Coastal Marine Ecosystems: A Global Problem. Environmental Science and Pollution Research 10(2): 126-139.

Smith VH, Schindler DW 2009. Eutrophication Science: Where do we go from here? Trends in Ecology and Evolution 24(4): 201-207.

Smith VH, Tilman GD, Nekola JC 1999. Eutrophication: impacts of excess nutrient inputs on freshwater, marine, and terrestrial ecosystems. Environmental Pollution 100: 179196. 
Statistics New Zealand 2013. Dairy industry 'mooooving' forward. Accessed on 30 October 2013, from http://www.stats.govt.nz/browse_for_stats/snapshots-of-nz/yearbook/ environment/agriculture/dairy.aspx.

Stamatiadis S, Werner M, Buchanan M 1999. Field assessment of soil quality as affected by compost and fertilizer application in a broccoli field (San Benito County, California). Applied Soil Ecology 12: 217-225

Statistics New Zealand 2013. Global New Zealand International trade, investment, and travel profile, Year ended June 2013. Wellington, Ministry of Foreign Affairs and Trade and Statistics New Zealand. 212 p.

Stecker JA, Buchholz DD, Tracy PW 1995. Fertilizer Sulfur Effects on Corn Yield and Plant Sulfur Concentration. Journal of Production Agriculture 8(1): 61-65.

Stevens CJ 2004. Impact of Nitrogen Deposition on the Species Richness of Grasslands. Science 303: 1876-1879.

Stevens CJ, Thompson K, Grime JP, Long CJ, Gowing DJG 2010. Contribution of acidification and eutrophication to declines in species richness of calcifuge grasslands along a gradient of atmospheric nitrogen deposition. Functional Ecology 24: 478-484.

Timmins SM, MacKenzie IW 1995. Weeds in New Zealand Protected Natural Areas Database. Department of Conservation technical series no. 8. Wellington, Department of Conservation. Pp. 1172-6873.

Tyler AC, Lambrinos JG, Grosholz ED 2007. Nitrogen inputs promote the spread of an invasive marsh grass. Ecological Applications 17(7): 1886-1898. 
Vance CP 2001. Symbiotic nitrogen fixation and phosphorus acquisition. Plant nutrition in a world of declining renewable resources. Plant Physiology 127: 390-397.

Vitousek PM, Howarth RW 1991. Nitrogen limitation on land and in the sea: How can it occur? Biogeochemistry 13: 87-115.

Vymazal J, Craft CB, Richardson CJ 2008. Plant community response to long term $\mathrm{N}$ and $\mathrm{P}$ fertilization. Ecological Studies 201: 505-527.

White PJ, Broadley MR 2003. Calcium in Plants. Annals of Botany 92: 487-511.

Williams PA, Timmins SM 1990. Weeds in New Zealand protected natural areas: A review for the Department of Conservation. Wellington, Department of Conservation. $291 \mathrm{p}$.

Zaller JG 2004. Ecology and non-chemical control of Rumex crispus and R. obtusifolius (Polygonaceae): a review. Weed Research 44(6): 414-432. 


\section{Appendix 2.6}

\section{Appendix 2.6.1}

Table 9 Relative GPS co-ordinates for the centre of each of the five treatment blocks in stage 2 of the Wairio Wetland.

\begin{tabular}{ccc}
\hline Block & Southing's & Easting's \\
\hline $\mathbf{1}$ & $41^{\circ} 14^{\prime} 56.85$ & $175^{\circ} 15^{\prime} 01.6$ \\
$\mathbf{2}$ & $41^{\circ} 14^{\prime} 56.7$ & $175^{\circ} 15^{\prime} 01.775$ \\
$\mathbf{3}$ & $41^{\circ} 14^{\prime} 56.325$ & $175^{\circ} 15^{\prime} 01.975$ \\
$\mathbf{4}$ & $41^{\circ} 14^{\prime} 54.95$ & $175^{\circ} 15^{\prime} 02.725$ \\
$\mathbf{5}$ & $41^{\circ} 14^{\prime} 54.725$ & $175^{\circ} 15^{\prime} 02.4$ \\
\hline
\end{tabular}




\section{Appendix 2.6.2}

Table 10 Fertiliser treatment concentrations for each plot $(1 \mathrm{~A}-2 \mathrm{E})$ in each block. $0=$ no addition (i.e. control), $1=$ low level addition, $2=$ high level addition. $\mathrm{N}=$ nitrogen, $\mathrm{P}=$ phosphorous.

\begin{tabular}{cccccc}
\hline Plots & \multicolumn{5}{l}{ Blocks } \\
\cline { 2 - 6 } & $\mathbf{1}$ & $\mathbf{2}$ & $\mathbf{3}$ & $\mathbf{4}$ & $\mathbf{5}$ \\
\hline 1A & $0 \mathrm{~N}: 0 \mathrm{P}$ & $1 \mathrm{~N}: 2 \mathrm{P}$ & $1 \mathrm{~N}: 1 \mathrm{P}$ & $1 \mathrm{~N}: 2 \mathrm{P}$ & $0 \mathrm{~N}: 1 \mathrm{P}$ \\
1B & $0 \mathrm{~N}: 1 \mathrm{P}$ & $0 \mathrm{~N}: 2 \mathrm{P}$ & $0 \mathrm{~N}: 0 \mathrm{P}$ & $0 \mathrm{~N}: 0 \mathrm{P}$ & $0 \mathrm{~N}: 0 \mathrm{P}$ \\
1C & $1 \mathrm{~N}: 2 \mathrm{P}$ & $2 \mathrm{~N}: 1 \mathrm{P}$ & $0 \mathrm{~N}: 1 \mathrm{P}$ & $1 \mathrm{~N}: 1 \mathrm{P}$ & $2 \mathrm{~N}: 1 \mathrm{P}$ \\
1D & $2 \mathrm{~N}: 0 \mathrm{P}$ & $1 \mathrm{~N}: 0 \mathrm{P}$ & $2 \mathrm{~N}: 2 \mathrm{P}$ & $2 \mathrm{~N}: 2 \mathrm{P}$ & $1 \mathrm{~N}: 0 \mathrm{P}$ \\
1E & $1 \mathrm{~N}: 1 \mathrm{P}$ & $0 \mathrm{~N}: 0 \mathrm{P}$ & $2 \mathrm{~N}: 0 \mathrm{P}$ & $0 \mathrm{~N}: 1 \mathrm{P}$ & $1 \mathrm{~N}: 2 \mathrm{P}$ \\
2A & $0 \mathrm{~N}: 2 \mathrm{P}$ & $2 \mathrm{~N}: 0 \mathrm{P}$ & $0 \mathrm{~N}: 2 \mathrm{P}$ & $1 \mathrm{~N}: 0 \mathrm{P}$ & $2 \mathrm{~N}: 0 \mathrm{P}$ \\
2B & $2 \mathrm{~N}: 2 \mathrm{P}$ & $0 \mathrm{~N}: 0 \mathrm{P}$ & $1 \mathrm{~N}: 0 \mathrm{P}$ & $0 \mathrm{~N}: 2 \mathrm{P}$ & $2 \mathrm{~N}: 2 \mathrm{P}$ \\
2C & $0 \mathrm{~N}: 0 \mathrm{P}$ & $2 \mathrm{~N}: 2 \mathrm{P}$ & $1 \mathrm{~N}: 2 \mathrm{P}$ & $2 \mathrm{~N}: 1 \mathrm{P}$ & $0 \mathrm{~N}: 2 \mathrm{P}$ \\
2D & $2 \mathrm{~N}: 1 \mathrm{P}$ & $1 \mathrm{~N}: 1 \mathrm{P}$ & $0 \mathrm{~N}: 0 \mathrm{P}$ & $0 \mathrm{~N}: 0 \mathrm{P}$ & $1 \mathrm{~N}: 1 \mathrm{P}$ \\
2E & $1 \mathrm{~N}: 0 \mathrm{P}$ & $0 \mathrm{~N}: 1 \mathrm{P}$ & $2 \mathrm{~N}: 1 \mathrm{P}$ & $2 \mathrm{~N}: 0 \mathrm{P}$ & $0 \mathrm{~N}: 0 \mathrm{P}$ \\
\hline
\end{tabular}




\section{Appendix 2.6.3}

Table 11 List of days visited Stage 2 for experimentation and activities undertaken at the site.

\begin{tabular}{|c|c|}
\hline Date & Activity \\
\hline $22^{\text {nd }}$ December 2012 & Site set-up \\
\hline $23^{\text {rd }}$ December 2012 & $\begin{array}{l}\text { Fertiliser addition and } \\
\text { species identification }\end{array}$ \\
\hline $27^{\text {th }}$ January 2013 & $\begin{array}{l}\text { Fertiliser addition and } \\
\text { species identification }\end{array}$ \\
\hline $3^{\text {rd }}$ March 2013 & $\begin{array}{l}\text { Fertiliser addition and } \\
\text { species identification }\end{array}$ \\
\hline $6^{\text {th }}$ March 2013 & Species identification \\
\hline $14^{\text {th }}$ April 2013 & $\begin{array}{l}\text { Fertiliser addition and } \\
\text { species identification }\end{array}$ \\
\hline $23^{\text {rd }}$ April 2013 & Soil sampling \\
\hline $24^{\text {th }}$ April 2013 & Species identification \\
\hline $19^{\text {th }}$ May 2013 & $\begin{array}{l}\text { Fertiliser addition and } \\
\text { species identification }\end{array}$ \\
\hline $21^{\text {st }}$ May 2013 & Species identification \\
\hline $23^{\text {rd }}$ June 2013 & $\begin{array}{l}\text { Found site flooded - } \\
\text { experiment halted }\end{array}$ \\
\hline
\end{tabular}




\section{Appendix 2.6.4}

Table 12 Linear mixed effects model showing the effect of fertiliser on $\mathrm{pH}$ and moisture levels within plots at the site (* indicates a significant p-value: $*<0.05, * *<0.01, * * *<0.001$ ).

\begin{tabular}{lllll}
\hline \multirow{2}{*}{ Fertiliser } & \multicolumn{2}{c}{$\mathbf{p H}$} & \multicolumn{2}{c}{ Moisture } \\
\cline { 2 - 5 } & $\mathbf{t}$ & $\mathbf{P}$ & $\mathbf{t}$ & $\mathbf{P}$ \\
\hline $\begin{array}{l}\text { Intercept } \\
\text { (control) }\end{array}$ & 35.970 & 0.000 & 10.831 & 0.000 \\
$\mathbf{N}$ & & & & \\
$\mathbf{P}$ & -0.487 & 0.629 & 0.350 & 0.728 \\
$\mathbf{N}$ x P & -0.629 & 0.533 & -1.302 & 0.200 \\
\hline
\end{tabular}




\section{Appendix 2.6.5}

Table 13 List of species identified in plots of the nutrient enrichment experiment (New Zealand Plant Conservation Network 2013).

\begin{tabular}{lllll}
\hline Scientific name & Plant codes & Common name & Occurrence & Status \\
\hline Agrostis capillaris & AGRCAP & Browntop & Common & Exotic \\
Agrostis stolonifera & AGRSTO & Creeping bent grass & Common & Exotic \\
Bidens frondosa & BIDFRO & Beggars tick & Common & Exotic \\
Eleocharis acuta & ELEACU & Sharp spike sedge & Rare & Native \\
Galium palustre & GALPAL & Marsh bedstraw & Common & Exotic \\
Glyceria fluitans & GLYFLU & Floating sweetgrass & Common & Exotic \\
Holcus lanatus & HOLLAN & Yorkshire fog & Rare & Exotic \\
Isolepis prolifera & ISOPRO & - & Common & Native \\
Juncus articulatus & JUNART & Jointed rush & Rare & Exotic \\
Leontodon autumninalis & LEOAUT & Autumn hawkbit & Common & Exotic \\
Lotus pedunculatus & LOTPED & Lotus & Common & Exotic \\
Rumex obtusifolius & RUMOBT & Broad-leaved dock & Common & Exotic \\
Schedonorus arundinaceus & SCHARU & Tall fescue & Rare & Exotic \\
Schoenoplectus pungens & SCHPUN & Three square & Common & Native \\
Trifolium fragiferum & TRIFRA & Pink clover & Common & Exotic \\
\hline
\end{tabular}




\section{Chapter 3}

\section{THE EFFECTS OF DIFFERENT REVEGETATION MANAGEMENT TREATMENTS ON THE ESTABLISHMENT OF NATIVE WOODY VEGETATION AT WAIRIO WETLAND}

\subsection{Introduction}

Revegetation is one of the main goals in ecological restoration of degraded wetlands. It ideally involves the planting or seeding of wetlands with native eco-sourced plants to accelerate the establishment of a native plant community (Porteous 1993). Revegetation can be expensive (Schirmer \& Field 2000), and time consuming (Meli et al. 2013), therefore high survival and growth rates of plantings are important to ensure reestablishment of a native plant community as well as continued financial and volunteer support in the project. Restoration practitioners are commonly faced with practical issues that can hinder plant establishment and the overall success of revegetation efforts. Some studies have found that the first year after planting is a crucial stage for establishing plants with both the highest rates of mortality and greatest growth rates experienced (Budelsky \& Galatowitsch 2000; Wilson et al. 2004). In contrast Keeton (2008) in riparian restoration found the greatest plant mortality was between the second and third year after planting. High plant mortality and low plant growth rates have been attributed to interspecific competition (Castro et al. 2002; Laarman et al. 2009; Stinson et al. 2006), herbivory of native plantings (Grove et al. 2006), soil waterlogging (Casanova \& Brock 2003), eutrophic soils (Kneitel \& Lessin 2010), plant diseases (Laarman et al. 2009), and extreme environmental conditions (Castro et al. 2002; Innes \& Kelly 1992).

Interspecific competition between different species for limited resources in an environment (inorganic nutrients, light or space) (Connell 1983; Goldberg 1990; Tilman 1997), is one of the strongest community interactions influencing plant establishment in wetlands (Budelsky \& Galatowitsch 2000; Goldberg \& Barton 1992; Schoener 1983). Competition can lead to plant mortality or reduced growth where dominant species outcompete and shade out 
smaller plants species (D'Antonio \& Meyerson 2002; Owen 1998; Stinson et al. 2006). Invasive weeds are common in degraded wetlands and are characterised by high competitive abilities, fast growth, and resilience to low levels of resources, which can prove detrimental to native plantings (Stinson et al. 2006). It is common in revegetation projects for nursery trees to be planted into retired paddocks where a high level of competition with grass species exists (Bodmin 2010). Reducing interspecific plant competition in revegetation projects is therefore crucial to ensure high survival of plantings and continued growth of those species that establish. Many management techniques have been explored over the years by restoration practitioners to increase survival and accelerate growth of new plants. Management techniques used have included the use of topsoil removal (Buisson et al. 2006; Patzelt et al. 2001; Rasran et al. 2007), weedmats (Grose 2012; Lai \& Wong 2005; Marcar et al. 2000), herbicide (Harrington \& Bedford 2004; Wilson \& Gerry 2006), altered tree spacing (Blignaut \& Milton 2005; Huddleston \& Young 2004) and the planting of 'nurse trees' (Camara 2001; Duarte et al. 2006; Janku 2013). The success of these methods changes between sites due to varied biotic and abiotic conditions experienced and can be speciesspecific. In New Zealand little is known about the success of different management techniques used at wetland sites and their effects on wetland plant species.

Topsoil removal is a management technique used in revegetation of many degraded sites. Topsoil removal has the potential to remove established weeds from an area (Buisson et al. 2006), remove excess soil nutrients (Hausman et al. 2007; Woodward 1996), facilitate natural regeneration (Gardiner \& Vaughan 2008), reduce species in the soil seed bank (Hölzel \& Otte 2003), and allow new plantings to establish in the absence of competitors at degraded sites (Patzelt et al. 2001). Studies in coastal prairies in Calfornia (Buisson et al. 2006), grasslands in Northern Germany (Rasran et al. 2007) and fen meadows in Southern Germany (Patzelt et al. 2001) have all reported significant increases in establishment of seedlings as a result of topsoil removal from the site. However, topsoil removal has also been linked to reductions in soil quality due to removal of crucial nutrients in the soil and alteration of soil processes (Geissen et al. 2013; Rasran et al. 2007; Wairiu \& Lal 2003), and the promotion of waterlogging by lowering of the water table (Booth \& Loheide 2010; Hausman et al. 2007; Hölzel and Otte 2003; Klimkowska et al. 2010b). Evidence on the 
effects of topsoil removal on wetland plants and its performance in wetland ecosystems is scarce. Topsoil removal is an expensive management technique (Klimkowska et al. 2010a) that can only be undertaken in restoration projects with large budgets and those that have landowners' permission or resource consent; therefore it is important to weigh up the costs and benefits of this technique before it is employed.

Weed mats can potentially increase plant survival and growth by acting as a barrier to growth of weeds close to plantings, blocking light to halt germination of seeds underneath the mats and thus reducing plant competition with weeds (Harrington \& Bedford 2004; Ogle 1996). Studies by Grose (2012) in a bush reserve in Perth, Australia and Smail et al. (2011) in a riparian site in Motueka, New Zealand have reported significant increases in native seedling survival and plant growth with the use of weedmats. Contrasting studies by Lai \& Wong (2005) in grassland on Lantau Island, Hong Kong and Marcar et al. (2000) in saline seeps, New South Wales which have reported weedmats can have no effect or an adverse effect on plants by the promotion of waterlogging.

Fast-growing hardy nurse trees are commonly planted at restoration sites with the potential to facilitate the establishment of slow growing target species (Castro et al. 2002). Nurse trees can reduce the need for ongoing weed control by competing with and shading out grasses (Hardwick et al. 1997), provide shelter from extreme environmental conditions (Cavieres et al. 2006), protect plants from herbivory (Calloway \& Pugnaire 1999), and improve soil and microclimate conditions to aid target species establishment (Dulohery et al. 2000). Studies in the Araucaria Forest, Brazil (Duarte et al. 2006) and Sierra Nevada mountains, Spain (Gómez-Aparicio et al. 2005) have shown greater seedling establishment when planted under established nurse trees. However, studies by Camara (2001) in Central Otago, New Zealand and McLeod et al. (2001) in South Carolina, USA found that nurse shrubs had no effect on the growth or survival of planted seedlings. When nurse trees are established, or larger than focal species they can also prove to be a significant competitor both above and below ground with native plantings for resources in an environment, proving detrimental. For example Prévsto \& Balandier (2007) in restoration of beech forests in Central France found that nurse trees restricted growth of target species due to 
interspecific competition. A study by Jankju (2013) in rangelands, Northeast Iran found that nurse trees only aided seedling establishment under normal conditions as under stress the nurse plants competed with seedlings for limited resources and the seedlings died. When planted simultaneously, the effects of nurse trees on target species are largely unknown.

Plant spacing is an important concept to consider in revegetation projects. Close spacing of plants can facilitate short-term growth and survival by providing a "nurse effect" such as protection from extreme environmental conditions, and reduced area for weeds to establish, however in the long-term closer spacing can lead to a reduction in growth and survival due to competition between plants for light, space and nutrients (Padilla \& Pugnaire 2006). In this sense there is a balance between plants facilitating or competing with each other. Huddleston \& Young (2004) in the Agate desert, Oregon and Blignaut \& Milton (2005) in shrublands, South Africa found growth rates of saplings were greater after 12 and 17 months respectively when spaced further apart due to presumed reductions in competition. In contrast a study by O'Brien \& Zedler (2006) in a salt marsh, California found seedlings in tighter clusters facilitated survivorship. Studies looking at the effects of plant spacing on growth and survival have not been undertaken in wetland environments.

Restoration plantings at Wairio Wetland, the subject of this study, have experienced variable success rates with between $50 \%$ and $70 \%$ survival of planted trees in recent years (Johnson 2012). Hence the overall goal of this project is to help inform restoration practices for Wairio Wetland to ensure success of future plantings. The two research aims are: 1) To assess which management techniques can promote survival and growth of plantings, and 2) To evaluate plant performance during the crucial time period after planting when seedlings are most vulnerable to mortality and identify the associated causes. This involved a large-scale planting experiment of 2368 trees planted under various pre-planting and aftercare treatments. I tested the hypotheses: 1) the use of weedmats, herbicide, topsoil scraping, and low-density planting of seedlings will promote the survival of all plants, 2) simultaneously planted nurse trees will promote the growth of focal plants, 3) the strongest determinant of plant mortality will be plant competition, and 4) plant mortality will be the greatest in the first year after planting. 


\subsection{Methods}

\subsubsection{Study site}

This study took place between July 2011 and July 2013 at Wairio Wetland, situated on the eastern shores of Lake Wairarapa, North Island, New Zealand. The Wairio Wetland is owned by the Department of Conservation (DOC) and its management is shared with Duck's Unlimited (DU). Fragmentation from nearby Boggy Pond and Matthews lagoon, drainage during the Lower Wairarapa Development Scheme in the 1960's and 1970's, exotic weed invasion, and pollution from nutrient runoff have all negatively impacted the wetland. The Wairio Wetland Restoration Committee formed in 2005 with aims to restore the wetland to a pristine state and have undertaken a staged approach to management. This experiment took place at a 5.6 ha management area of the wetland known as Stage 3 (Figure 16). Restoration activities have taken place by the committee at Stage 3 since 2008. Dams were constructed at the northern and southern ends to retain water, and a full fence was built around Stage 3 to exclude cattle from the site. Previous planting at the site has been met with variable survival rates of between $50 \%$ and $75 \%$ (Johnson 2012).

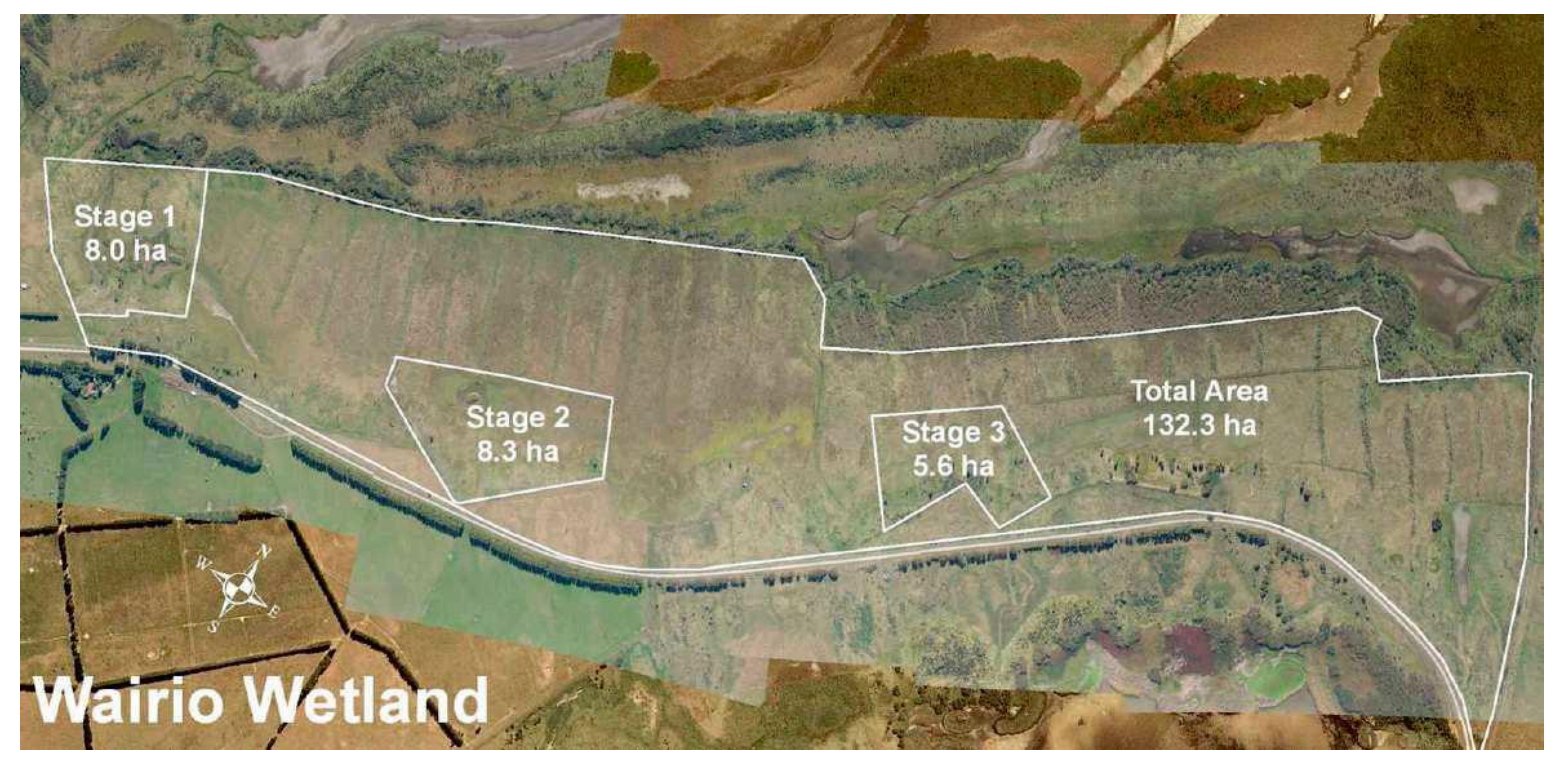

Figure 16 Aerial picture of Wairio Wetland and its respective management stages (Greater Wellington Regional Council, 2010).

The site is low-lying, with a central permanent pond and experiences flooding in its western fringes annually between June and November. In June 2011, Masters student Bridget Johnson, of Victoria University of Wellington, began a large-scale planting experiment at the 
site which this study continues. For more detailed methods please refer to her thesis (Johnson 2012).

\subsubsection{Study species}

A total of eight tree/shrub species were used for this study (Appendix 3.6.1). The trees were selected by previous Masters student Bridget Johnson. Species selected were native to New Zealand and either presently found at the site or historically local to the southern Wairarapa area (Enright et al. 2008).

Four native New Zealand nurse species were chosen and grouped into sets, with the first set including Coprosma robusta (karamu) and Coprosma propinqua (mikimiki), and the second set including Leptospermum scoparium (manuka) and Pittosporum tenuifolium (kohukohu). Nurse species selected were fast growing hardy species with the ability to prosper in variable environmental conditions characteristic of wetland sites (Cockayne 1923). Nurse species were used to potentially facilitate the growth and survival of focal trees by shading and suppressing weed species (Hardwick et al. 1997), providing protection from wind (Cavieres et al. 2006) and herbivory (Calloway \& Pugnaire 1999), or improving soil and microclimate conditions to aid establishment (Dulohery et al. 2000). The four focal species selected included Cordyline australis (cabbage tree), Dacrycarpus dacrydioides (kahikatea), Olearia virgata (bush daisy) and Podocarpus totara (totara). Focal species selected were generally slow-growing species characteristic of mature swamp forests in the area.

Plant stock was purchased from Norfolk Road Nursery and Akura Conservation Centre in the Wairarapa. Plants were grown from eco-sourced seed.

Nurse species:

1. Coprosma robusta is a very common shrub or small tree found throughout New Zealand in lowlands and shrublands that experience high rainfall (Dawson \& Lucas 2000, Metcalfe 1993). It is a fast growing species that peaks at six metres tall and can tolerate seasonal flooding and desiccation (Clarkson \& Peters 2010, New Zealand Plant Conservation Network (hereafter referred to as NZPCN) 2013). It is easy to cultivate and is thus commonly used in restoration plantings (Cockayne 1923). It has 
dark green glabrous leaves, and orange berries (Dawson \& Lucas 2000, Poole \& Adams 1994).

2. Coprosma propinqua is a small shrub species commonly found in areas with high rainfall throughout New Zealand (NZPCN 2013). It is well-adapted to wet and dry conditions and can be easily cultivated (Cockayne 1923). It can reach up to seven metres tall and has thick linear-oblong/obovate leaves (Poole \& Adams 1994).

3. Leptospermum scoparium is a common shrub/ small tree species found in various habitats both wet and dry throughout New Zealand (NZPCN 2013). It is a fast growing hardy plant that can reach up to four to eight metres tall and can survive in many conditions whether exposed to or sheltered from the wind, fertile or infertile soils, desiccated or waterlogged and even brackish water (Cockayne 1923, Cook et al. 1980, Dawson \& Lucas 2000). It is a strong competitor for nutrients and is light demanding (Porteous 1993). It has small prickly leaves and abundant pinkish-white flowers (Poole \& Adams 1994).

4. Pittosporum tenuifolium is a hardy small tree common in various habitats throughout New Zealand that can reach eight to ten metres tall (NZPCN 2013). It can tolerate most soil conditions and windy sites (Cockayne 1923). It has green oblong leaves with a wavy margin and blackish-purple flowers (Poole \& Adams 1994).

Focal species:

1. Cordyline australis is a hardy fast growing species that can tolerate a wide range of environmental conditions and is found in most habitats throughout New Zealand, often abundant in swamplands (Smale et al. 2001, NZPCN 2013). It can be cultivated in a majority of soil types and does well when planted in groups (Cockayne 1923). Cabbage trees can withstand periodic flooding and desiccation (Clarkson \& Peters 2010), and can reach heights of up to $12 \mathrm{~m}$ when mature (Dawson \& Lucas 2000). Its distinguishing feature is abundant erect green inflorescences, up to one metre in length (Dawson \& Lucas 2000). Cabbage tree populations in New Zealand since the 1980's have suffered from Sudden Decline, a bacterial disease that causes wilting, decay and death of trees (Beever et al. 1996). Young cabbage trees are also commonly eaten by livestock and rabbits. 
2. Dacrycarpus dacridioides or white pine is the tallest native tree of New Zealand and can reach up to $50 \mathrm{~m}$ (Dawson \& Lucas 2000). It is the dominant tree found in swamp forests thriving in damp areas and seasonally flooded wetland margins (Cockayne 1923, NZPCN 2013). It remains in a small and slender juvenile stage for a long time (Cockayne 1923), however when mature has distinct rounded buttresses with extensive root systems. It bears yellow pollen cones and tear-drop shaped orange-red fleshy receptacles with black seeds attached (Dawson \& Lucas 2000, Poole \& Adams 1994).

3. Olearia virgata is a twiggy shrub species commonly found in wet areas throughout New Zealand (NZPCN 2013). It is a hardy species resistant to frost, water inundation, and harsh weather conditions. It is a rapidly growing species that can reach four metres tall and is easy to cultivate thus suitable for restoration plantings (Cockayne 1923). It has small thin leaves on rounded branchlets (Poole \& Adams 1994).

4. Podocarpus totara is an endemic conifer tree widely distributed throughout New Zealand, found in lowlands and hill country on well-drained soils (Dawson \& Lucas 2000). It is a slow-growing tree and that reach up to $30 \mathrm{~m}$ tall when mature and has a large trunk up to two metres in diameter with stringy bark, and distinct red fruit (Poole \& Adams 1994). It has been known to establish well in degraded sites from readily dispersed fresh seed and is thus used extensively in restoration plantings (Enright \& Ogden 1995, Smale et al. 2001). 


\subsubsection{Management treatments}

Five treatment techniques were investigated, each with two or three treatment options (Table 14). Twenty eight of 32 possible treatment combinations were tested at the site and replicated across 56 plots (Appendix 3.6.2).

Table 14 Five treatments with corresponding treatment options

\begin{tabular}{ll}
\hline Treatment techniques & Treatment options \\
\hline Topsoil & Topsoil retained (1) \\
& Topsoil excavated (0) \\
\hline Weedmat or spot & Weedmat present, no spot spraying (1) \\
spraying of herbicide & No weedmat, spot spraying follow-up (0) \\
\hline Planting order & No nurse trees (focal species only) \\
& Concurrent planting (both focal and nurse species) \\
\hline Nurse tree spacing & Advance planting (nurse species only) \\
(from one another) & 1.5m spacing \\
\hline Nurse species & No nurse species (0) \\
& C. robusta and C. propinqua (1) \\
& L. scoparium and $P$. tenuifolium (2) \\
\hline
\end{tabular}




\subsubsection{Site layout}

Trees were planted in 56 plots (one plot being an array of either 16, 48 or 64 trees). Plots were grouped into ten blocks over the site at stage 3, Wairio Wetland (Figure 17). The ten blocks were divided in half with one side having topsoil excavated and the other having topsoil retained. Eight of the ten blocks $(40 \mathrm{~m} \times 30 \mathrm{~m}$ each) were divided into three plots in each half (representing the three different planting orders: no nurse trees, concurrent planting of nurse and focal trees, and advanced planting of nurse trees) (Figure 18). These were blocks $3-10$. The remaining two blocks $(30 \mathrm{~m} \times 30 \mathrm{~m})$ were split into two plots in each half (concurrent planting and no nurse trees) (Figure 19). These were blocks 1 and 2. Each individual plot was further divided into quarters with weedmats placed around trees in two opposing corners.

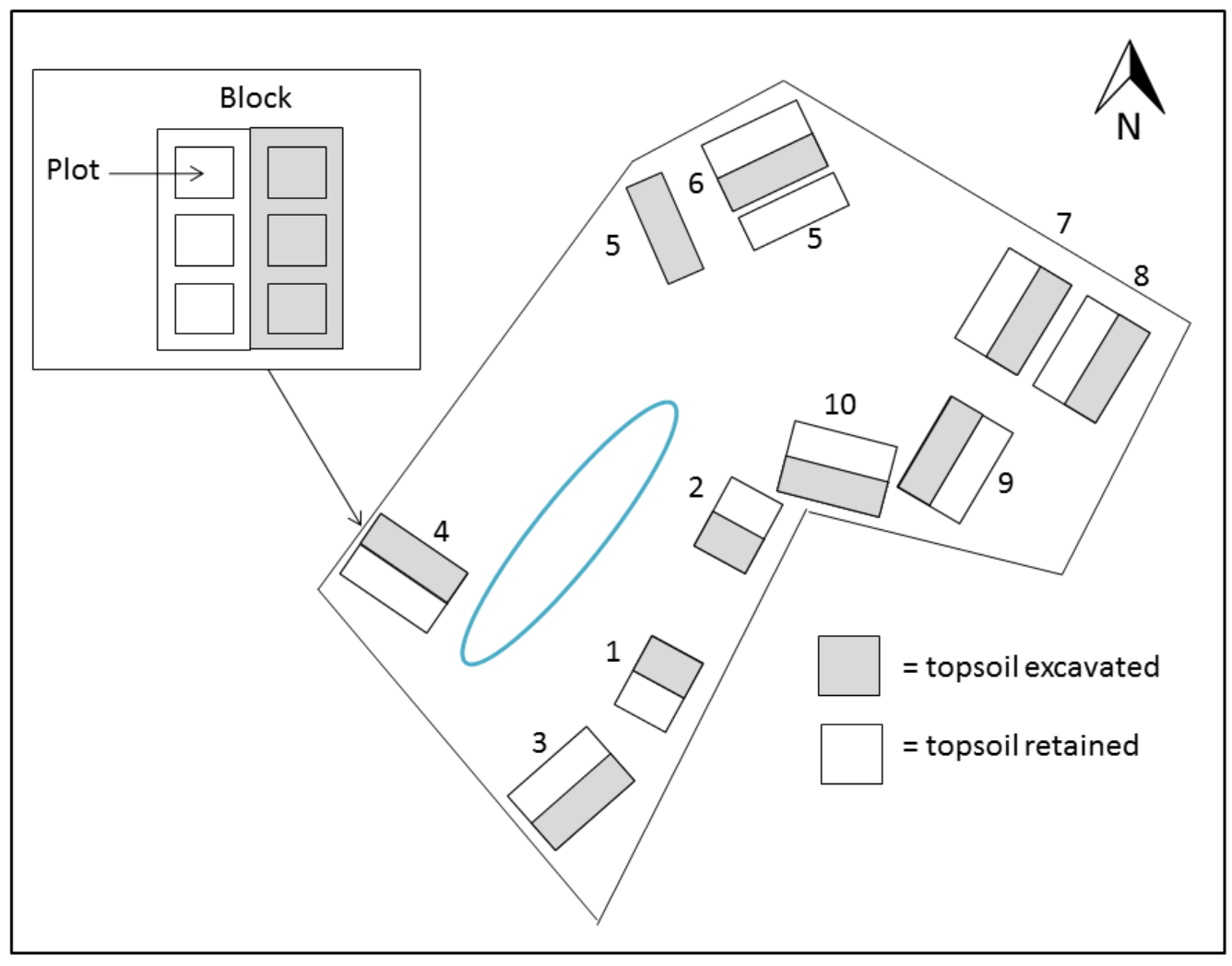

Figure 17 Stage 3 of Wairio Wetland showing respective block layout. Inset shows layout of plots within each block. The permanent pond is outlined in blue. Not drawn to scale. 


\subsubsection{Treatment methods}

The outline of the blocks were measured, staked, and labelled. Tree planting spots were marked with spray paint to ensure correct placement. The planting was organised by a previous Masters student.

\section{Topsoil}

On 29 April 2011, approximately $10 \mathrm{~cm}$ of topsoil was excavated, using a bulldozer, from half of the 10 blocks at the site. The other half of the ten blocks with intact topsoil were spot sprayed by a GWRC contractor on 31 May 2011. Herbicide (Buster, glufosinate-ammonium and Gardoprim, terbuthylazine) was applied $1 \mathrm{~m}^{2}$ around each tree marking, apart from natives planted at $0.75 \mathrm{~m}$ which had the whole plot sprayed.

\section{Weedmats}

On 25 August 2011, one month after tree planting, felt weedmats $(60 \times 60 \mathrm{~cm}$ with a central opening) were applied and secured around the saplings in two opposite quarters of each plot (56 plots). Those saplings without weedmats applied were spot sprayed with a mixture of Buster and Gardoprim herbicide on 11 November 2011. From that point onwards all trees regardless of the original presence or absence were release sprayed twice a year thereafter.

\section{Planting order, nurse spacing and species}

Concurrent planting of both nurse and focal tree species at $1.5 \mathrm{~m}$ spacing occurred in 20 plots across the 10 blocks - one excavated and one retained (Figures 18-19). The four native nurse species were paired into two sets (1) C. robusta and C. propinqua, (2) L. scoparium and $P$. tenuifolium. In each plot, four individuals of each of the four focal species were planted concurrently between the nurse species.

Advanced planting consisted of only nurse species being planted in 16 plots across 8 of the blocks. The paired nurse species were planted within the plots at either $1.5 \mathrm{~m}$ spacing or $0.75 \mathrm{~m}$ spacing. Stakes were distributed in between the nurse species to mark spaces for native trees to be planted within three to four years. 
Planting of focal species without nurse trees (the "no nurse" treatment) was used as a control treatment with 16 focal trees planted in the same order as other plots but with no nurse trees. This pattern was replicated in 20 plots across the 10 blocks. 


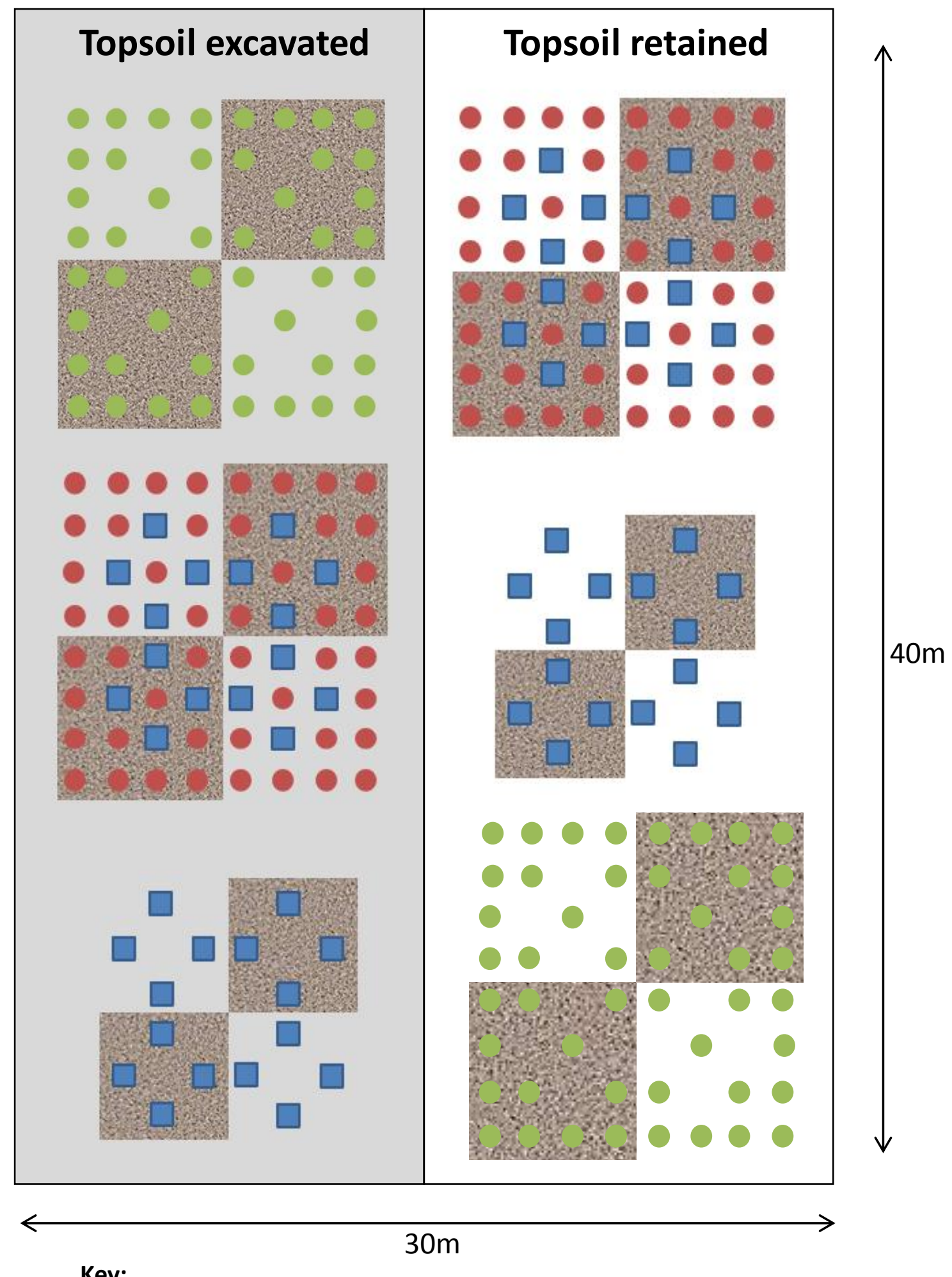

Key:

Concurrent planting of nurse species

Advance planting of nurse species $0.75 / 1.5 \mathrm{~m}$

Focal species

W. Weedmats
Figure 18 There are eight large blocks $(30 \mathrm{~m} \times 40 \mathrm{~m})$ each containing 96 focal and 192 nurse trees (288 in total). Blocks 3-10. Not to scale. Figure adapted from Johnson 2012. 


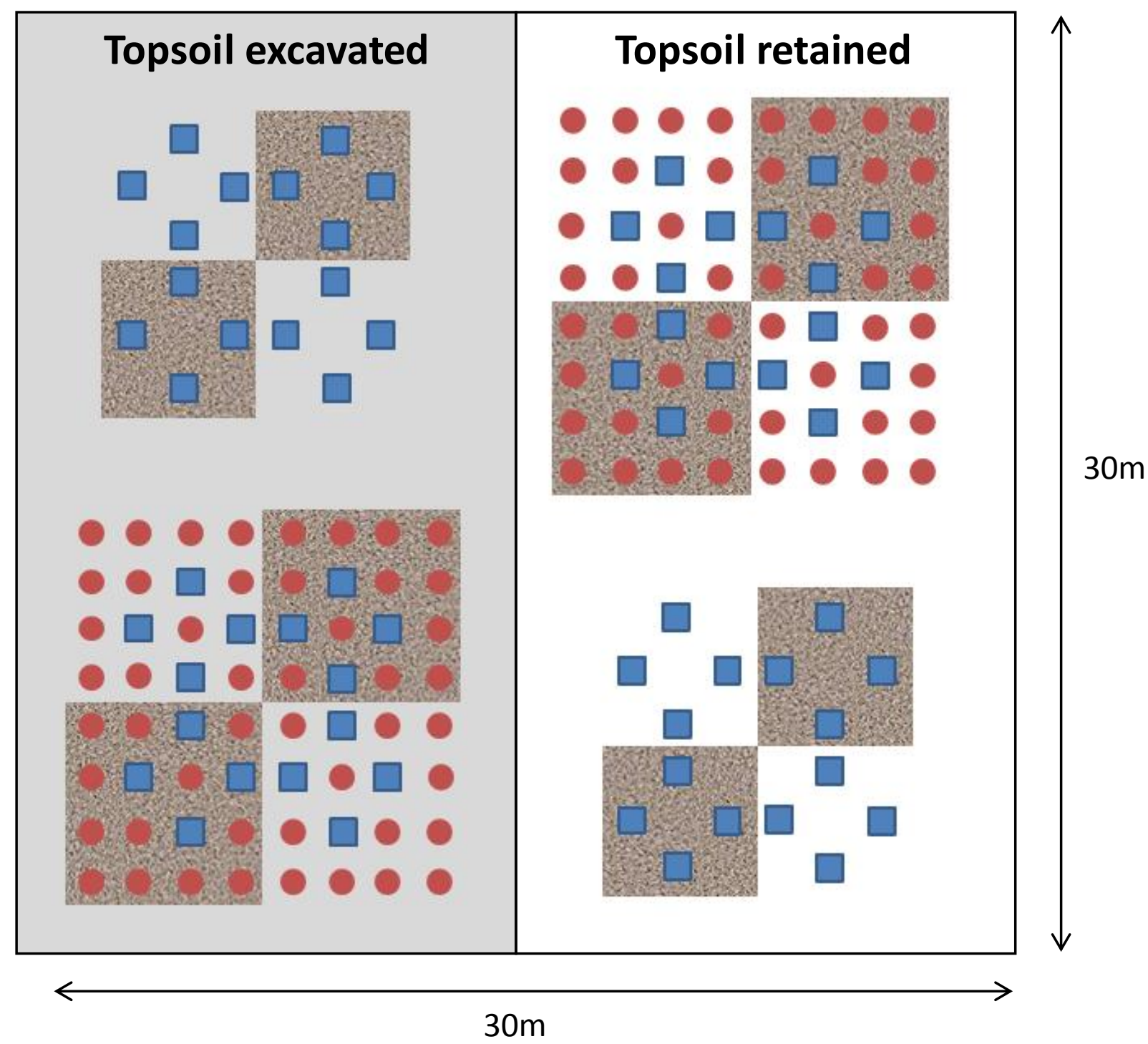

Key:

Nurse species

Focal species

5. Weedmats
Figure 19 There are two medium blocks (30m $\times 30 \mathrm{~m}$ ) each containing 64 focal and 96 nurse trees (288 in total). Blocks 1-2. Not to scale. Figure adapted from Johnson 2012. 


\subsubsection{Tree planting}

A total of 2,368 trees were planted at the site between $23^{\text {rd }}$ June 2011 and $4^{\text {th }}$ July 2011 with help from 30 volunteers (Table 15). Volunteers were briefed on correct planting procedure.

Table 15 Number of native trees planted in 2011 (adapted from Johnson 2012).

\begin{tabular}{|c|c|c|c|c|}
\hline Medium blocks & $\begin{array}{l}\text { Total number of } \\
\text { trees per block }\end{array}$ & $\begin{array}{l}\text { Number of } \\
\text { blocks }\end{array}$ & Number of trees & \\
\hline Focal & 64 & 2 & 128 & \\
\hline Nurse & 96 & 2 & 192 & \\
\hline Subtotal & 160 & - & 320 & \\
\hline \multicolumn{5}{|l|}{ Large blocks } \\
\hline Focal & 64 & 8 & 512 & \\
\hline Nurse & 192 & 8 & 1536 & \\
\hline Subtotal & 288 & - & 2048 & \\
\hline Total & & & & Per species \\
\hline Focal & - & 10 & 640 & 160 \\
\hline Nurse & - & 10 & 1728 & 432 \\
\hline Grand total & - & - & 2368 & \\
\hline
\end{tabular}




\subsubsection{Monitoring}

All native focal species (160 of each species) were labelled with Aluminium tags (Forestry tools, alutags) when first planted in July 2011. The species were given code names according to their scientific names ( $\mathrm{Ca}, \mathrm{Dd}, \mathrm{Ov}, \mathrm{Pt})$ and numbered 1 to 160 starting from block one through to block ten. Trees were measured approximately every six months in July 2011, December 2011, June 2012, January 2013, June 2013 and January 2014. Focal species survival and height were measured at each time point, however nurse species survival was not recorded in January 2012 and nurse species height was not measured in July 2011 or January 2012. Survival and height of trees in Blocks 4-6 could not be completed in June 2013 due to inaccessibility of the plots (high water levels). Variables measured for each individual tree include the height $(\mathrm{cm})$, weed mat presence/absence, spot spraying presence/absence, percentage water cover, respective average water depth $(\mathrm{cm})$ and cause of death. Tree height was measured with a common ruler from ground level to the highest leaf. Podocarpus totara and $C$. australis were commonly found lying on the ground and were pulled upright to measure the tallest leaf. Percentage water cover for each tree was measured in a $1 \mathrm{~m}^{2}$ quadrat surrounding each sapling. The average percentage water across all time periods was used for statistical modelling. Species were assigned a probable cause of death based on observation. Causes of death included weed competition, waterlogging, exposure, herbivory, herbicide or unknown causes (Table 16).

Table 16 Probable causes of plant death.

\begin{tabular}{ll}
\hline Cause of death & Evidence \\
\hline Weed competition & Sapling fully overgrown by weeds \\
Waterlogging & Sapling immersed in $100 \%$ water cover before death \\
Exposure & Sapling pushed over by wind or dry soil surrounding tree \\
Herbivory & Sapling fully or partially eaten \\
Herbicide & Sapling wilting/decaying \\
Unknown & No other suspected cause of death \\
\hline
\end{tabular}




\subsubsection{Statistical analysis}

\section{Survival}

Survival of each species 30 months after planting was analysed using a linear mixed effects model. Fixed effects (predictor variables) used in the model were topsoil (excavated or retained), weed control (weedmat or spray), average percentage water (average of the six measurements collected over the last 30 months) and all two-way interactions between these effects. The presence/absence of nurse trees was included as a fixed effect when modelling focal species, and nurse spacing $(0.75 \mathrm{~m}$ or $1.5 \mathrm{~m})$ was included as a fixed effect for modelling nurse species. A binomial distribution for residuals was assumed. Random effects were "plot" nested within "block". After the full model was obtained, interaction terms with $P>0.2$ were removed. The model was further reduced by sequential removal of the least significant interaction term and this process was repeated until the AIC increased. The model with the lowest AIC was selected as the best approximating model. "Main effects" were always included. The effect of advance planting of nurse species on survival of focal species was not included in the model as focal species have not yet been planted in advance planting plots. P-values are used throughout the paper for judging significance of fixed effects and are considered significant when $\mathrm{P} \leq 0.05$. No survival or height data was collected at the 24-month mark from block four, and parts of block five and six due to water inundation at the site.

The cost of management treatments were evaluated per tree (excluding labour costs). The survival (proportion alive) of each species per management treatment combination was calculated after 30 months of planting. A cost-benefit analysis was calculated for each species and management treatment (Equation 2).

\section{Equation 2 Cost-benefit analysis:}

$$
\mathrm{CBA}=\frac{\text { Total cost of treatment }}{\text { Proportion alive (survival) }}=\text { cost per surviving tree }
$$




\section{Growth}

Growth (change in height) of each species over the 30-month period was analysed using a linear mixed effects model. The response variable was change in height $(\mathrm{cm})$ with fixed effects and other methods used the same as above.

Data was analysed using the statistical programming software $R$ (Version 2.15.1) ( $R$ Development Core Team, 2013), using the 'Imer' command from the R package 'Ime4' for the binary survival data (Bates et al. 2013) and the 'Ime' command from the R package 'nlme' for the continuous growth data (Pinheiro et al. 2013). 


\subsection{Results}

\subsubsection{Plant survival}

Figure 20 shows that mean survival of focal species (54\%) was greater than the mean survival of nurse species (39\%), 30 months after planting. Dacrycarpus dacrydioides had the greatest survival of all focal species at $71 \%$, followed by lower survival of $O$. virgata and $C$. australis both at $50 \%$ and $P$. totara at $44 \%$. Leptospermum scoparium had greatest survival of the nurse species at $56 \%$, followed by $P$. tenuifolium at $44 \%$, with lower survival of $C$. propinqua at $30 \%$ and C. robusta at $26 \%$.
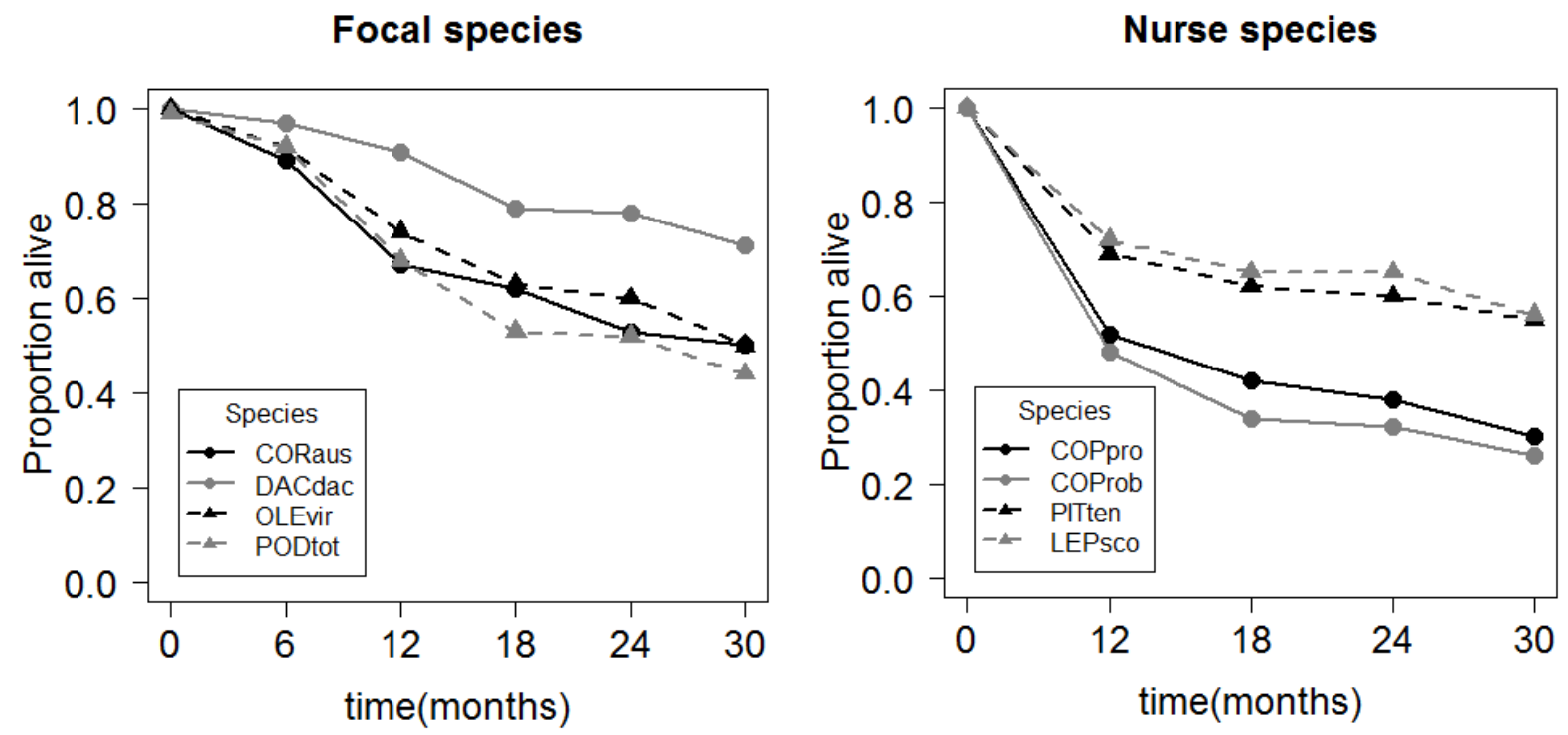

Figure 20 Survival (proportion alive) of focal and nurse species over the 30 month period since planting. Nurse species survival was not recorded at the 6 month mark. Focal species are represented as CORaus $=$ Cordyline australis, DACdac $=$ Dacrycarpus dacrydioides, OLEvir $=$ Olearia virgata, PODtot $=$ Podocarpus totara. Nurse species are represented as COPpro = Coprosma propinqua, COProb = Coprosma robusta, PITten = Pittosporum tenuifolium, LEPsco = Leptospermum scoparium . 


\subsubsection{Plant mortality}

Tables 17 and 18 suggest the greatest plant mortality was experienced in the first 12 months after planting, with focal species mortality at $25.1 \%$ and nurse species mortality at $34.8 \%$. The lowest plant mortality of all species was experienced between the 18 and 24 month period since planting, with focal species mortality at $3.6 \%$ and nurse species mortality at $2 \%$.

Table 17 Mortality rates of focal species per six month interval, measured over the 30month period since planting. Mortality was calculated as the number alive at the end point divided by the number alive at the start of each time period. The 0-12 month time period was added for comparison with nurse species mortality.

\begin{tabular}{lccccc}
\hline $\begin{array}{l}\text { Time period } \\
\text { (months) }\end{array}$ & C. australis & D. dacridioides & O. virgata & P. totara & Average \\
\hline $0-6$ & $11.3 \%$ & $3.1 \%$ & $8.1 \%$ & $8.3 \%$ & $7.7 \%$ \\
\hline $6-12$ & $21.9 \%$ & $5.6 \%$ & $18.1 \%$ & $24.1 \%$ & $17.4 \%$ \\
\hline $\mathbf{0 - 1 2}$ & $\mathbf{3 3 . 1 \%}$ & $\mathbf{8 . 8 \%}$ & $\mathbf{2 6 . 3} \%$ & $\mathbf{3 2 . 3}$ & $\mathbf{2 5 . 1 \%}$ \\
\hline $12-18$ & $5.0 \%$ & $12.5 \%$ & $10.6 \%$ & $14.6 \%$ & $10.7 \%$ \\
\hline $18-24$ & $8.8 \%$ & $1.3 \%$ & $3.1 \%$ & $1.3 \%$ & $3.6 \%$ \\
\hline $24-30$ & $3.1 \%$ & $6.3 \%$ & $10 \%$ & $7.6 \%$ & $6.8 \%$ \\
\hline
\end{tabular}

Table 18 Mortality rates of nurse species per six month interval, measured over the 30month period since planting. Mortality was calculated as the number alive at the end point divided by the number alive at the start of each time period. Survival was not recorded at the six month mark so mortality could not be calculated for 0-6 months after planting.

\begin{tabular}{lrcccc}
\hline $\begin{array}{l}\text { Time period } \\
\text { (months) }\end{array}$ & C. robusta & C. propinqua & L. scoparium & P. tenuifolium & Average \\
\hline $0-12$ & $42.1 \%$ & $38 \%$ & $28.0 \%$ & $31.0 \%$ & $34.8 \%$ \\
\hline $12-18$ & $13.9 \%$ & $10.2 \%$ & $6.9 \%$ & $6.9 \%$ & $9.5 \%$ \\
\hline $18-24$ & $2.1 \%$ & $3.9 \%$ & $0.0 \%$ & $2.1 \%$ & $2.0 \%$ \\
\hline $24-30$ & $6.0 \%$ & $7.9 \%$ & $9.0 \%$ & $4.9 \%$ & $7.0 \%$ \\
\hline
\end{tabular}


Table 19 proposes that waterlogging at the site appeared to cause the highest plant mortality at Wairio with 667 plant deaths, followed by weeds competing with saplings, which contributed to 179 deaths at the site. Herbivory of plants, exposure to the wind/sun, and accidental herbicide application also contributed to some plant deaths at the site. In particular, C. australis had eight deaths attributed to herbicide and twelve deaths attributed to herbivory.

Figures 21-26 show that survival rates differed between blocks at Wairio and between different species. Appendix 3.6.3 shows that the highest overall plant survival was experienced in block seven and block three with $76 \%$ and $72 \%$ of plants alive respectively, 30 months after planting. The lowest overall plant survival was experienced in block five with $5 \%$ of plants alive, followed by block six with $13 \%$ of plants alive. In contrast, $D$. dacridioides had relatively high survival in blocks five and six of $38 \%$ and $88 \%$ plant survival respectively. 
Table 19 Number of deaths attributed to a probable cause for each species based on field observations.

\begin{tabular}{|c|c|c|c|c|c|c|c|c|c|}
\hline \multirow{2}{*}{$\begin{array}{l}\text { Probable } \\
\text { cause of death }\end{array}$} & \multicolumn{4}{|c|}{ Focal species (160 per species) } & \multicolumn{4}{|c|}{ Nurse species (432 per species) } & \multirow[t]{2}{*}{ Total } \\
\hline & C. australis & D. dacridioides & O. virgata & P. totara & C. propinqua & C. robusta & P. tenuifolium & L. scoparium & \\
\hline $\begin{array}{l}\text { Weed } \\
\text { competition }\end{array}$ & 9 & 17 & 15 & 13 & 38 & 33 & 30 & 24 & 179 \\
\hline Waterlogging & 34 & 13 & 43 & 50 & 174 & 165 & 105 & 83 & 667 \\
\hline Exposure & 1 & 0 & 2 & 2 & 3 & 6 & 8 & 10 & 32 \\
\hline Herbivory & 12 & 2 & 7 & 2 & 4 & 6 & 1 & 1 & 35 \\
\hline Herbicide & 8 & 0 & 0 & 0 & 0 & 0 & 0 & 0 & 8 \\
\hline Unknown & 15 & 9 & 13 & 24 & 81 & 104 & 61 & 73 & 380 \\
\hline
\end{tabular}




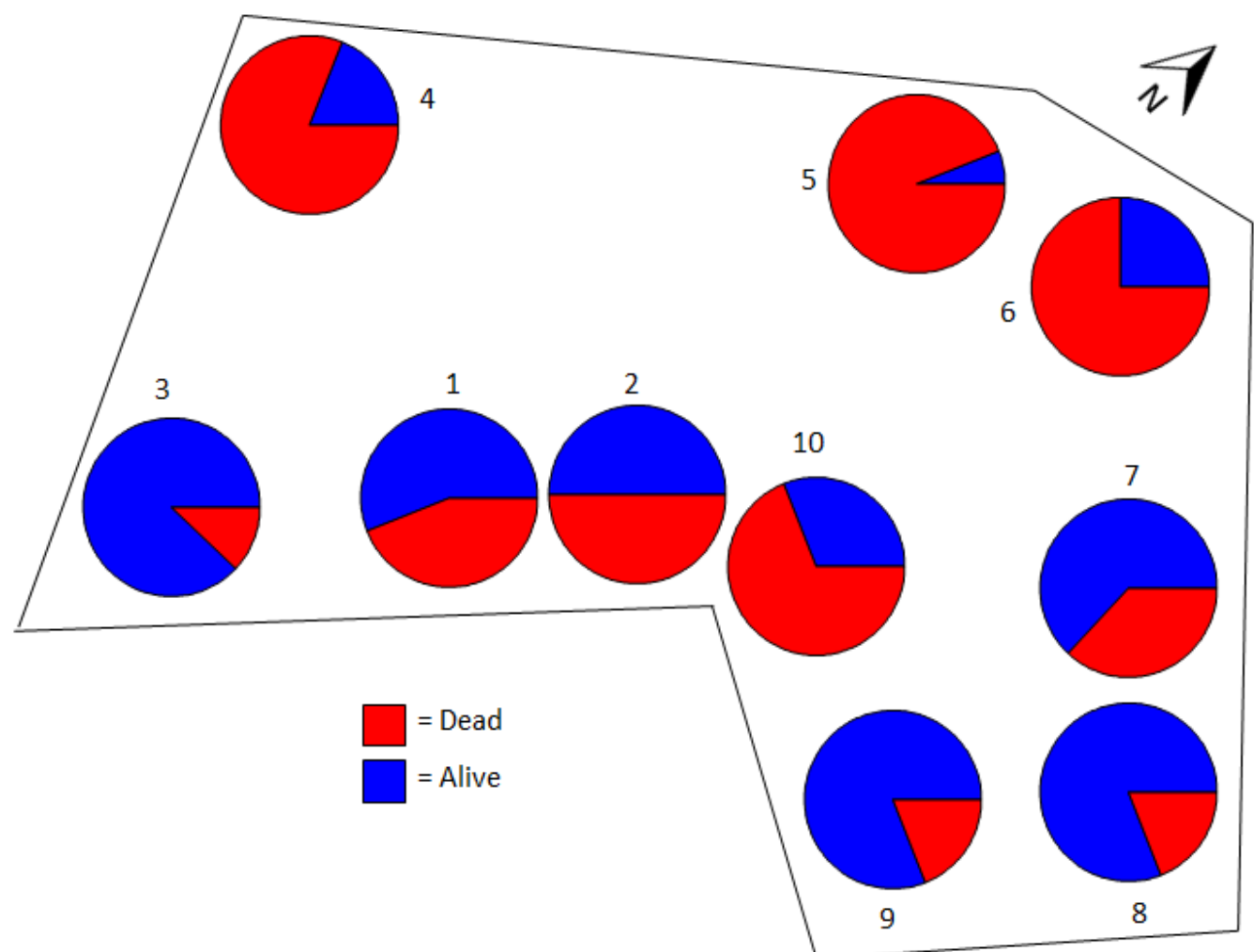

Figure 21 Pie graphs showing proportion of C. australis surviving in blocks 1-10 at Wairio Wetland after 30 months.

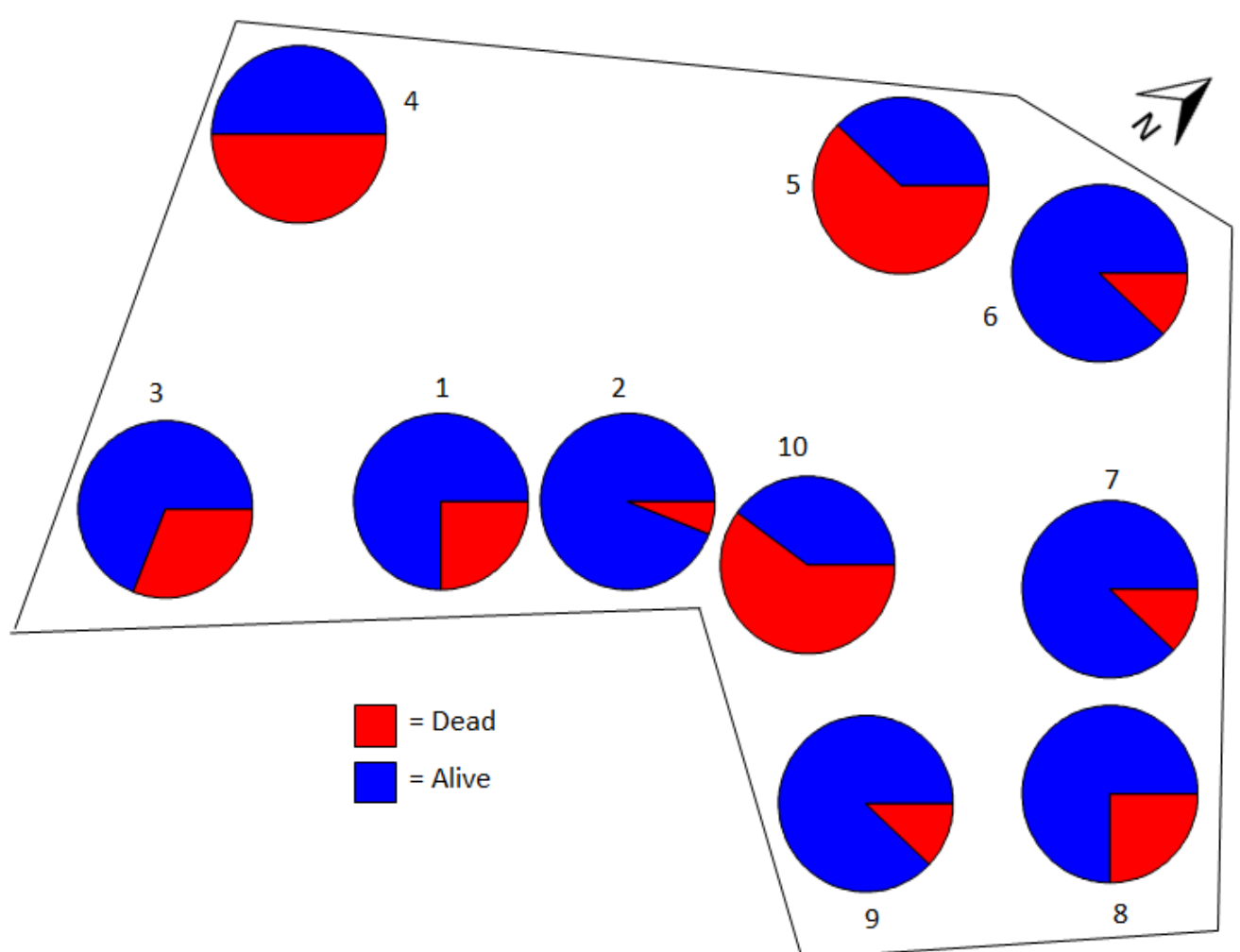

Figure 22 Pie graphs showing proportion of $D$. dacridioides surviving in blocks 1-10 at Wairio Wetland after 30 months. 


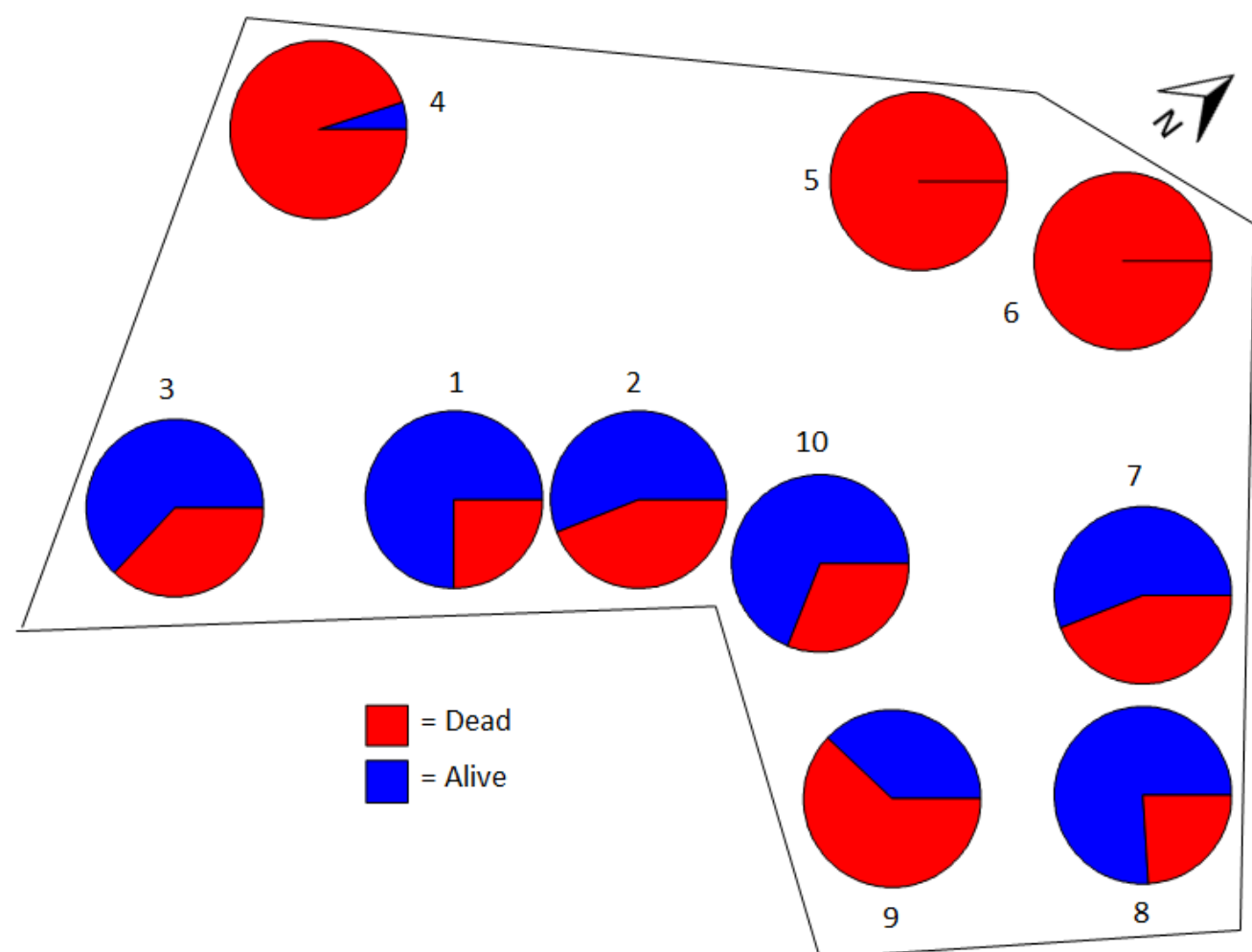

Figure 23 Pie graphs showing proportion of $P$. totara surviving in blocks $1-10$ at Wairio Wetland after 30 months.

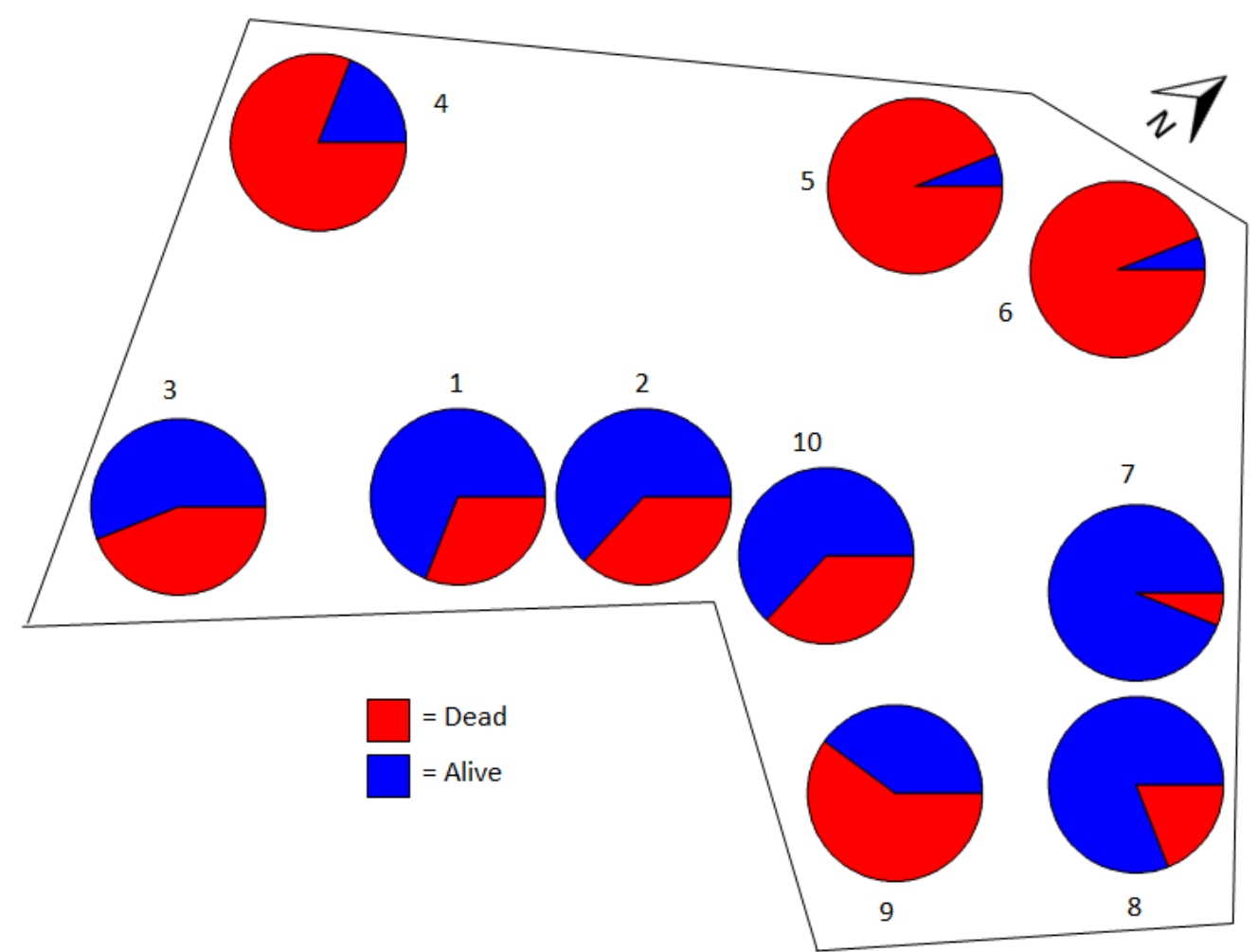

Figure 24 Pie graphs showing proportion of O. virgata surviving in blocks 1-10 at Wairio Wetland after 30 months. 


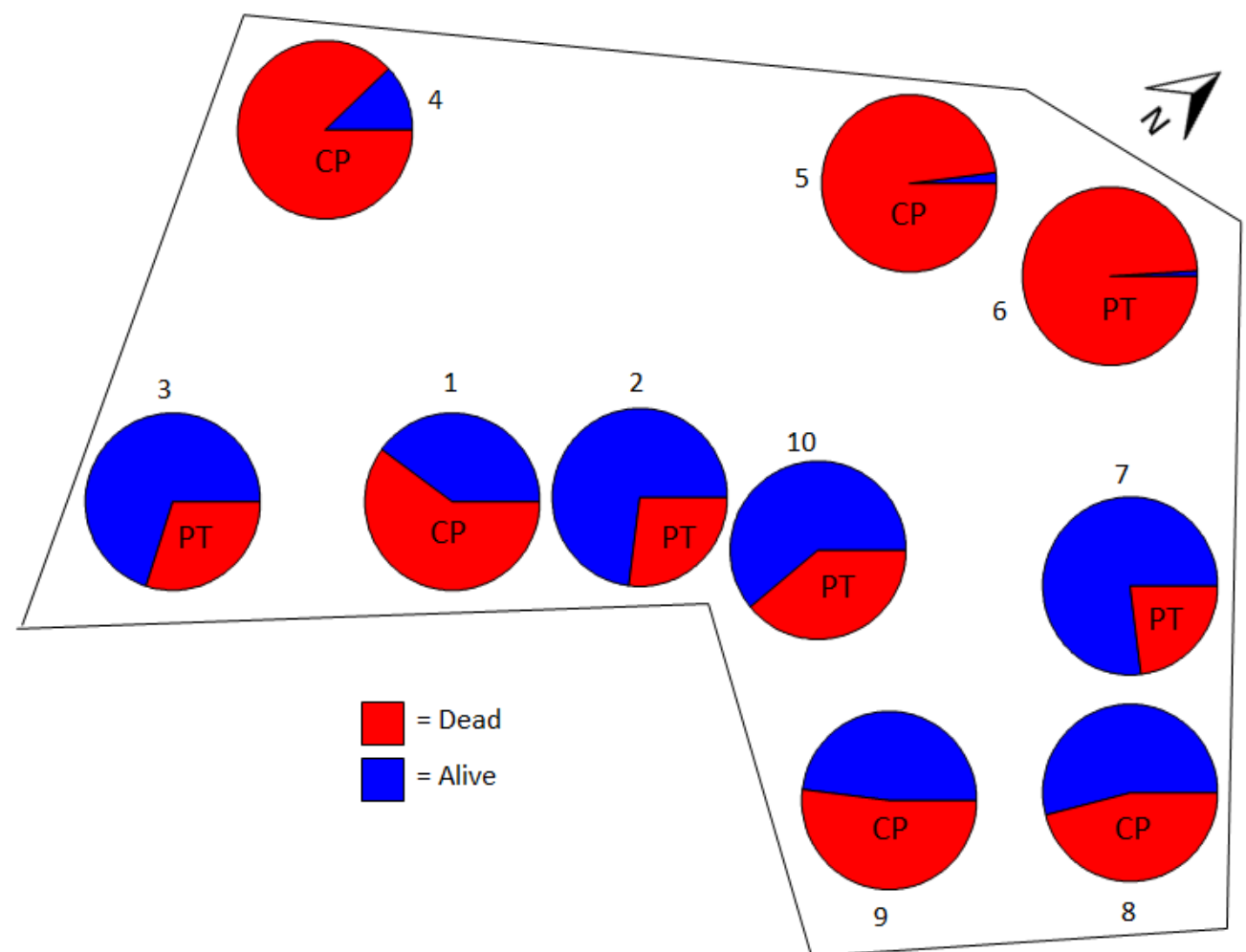

Figure 25 Pie graphs showing proportion of $C$. propinqua (CP) and P. tenuifolium (PT) surviving in blocks 1-10 at Wairio Wetland after 30 months.

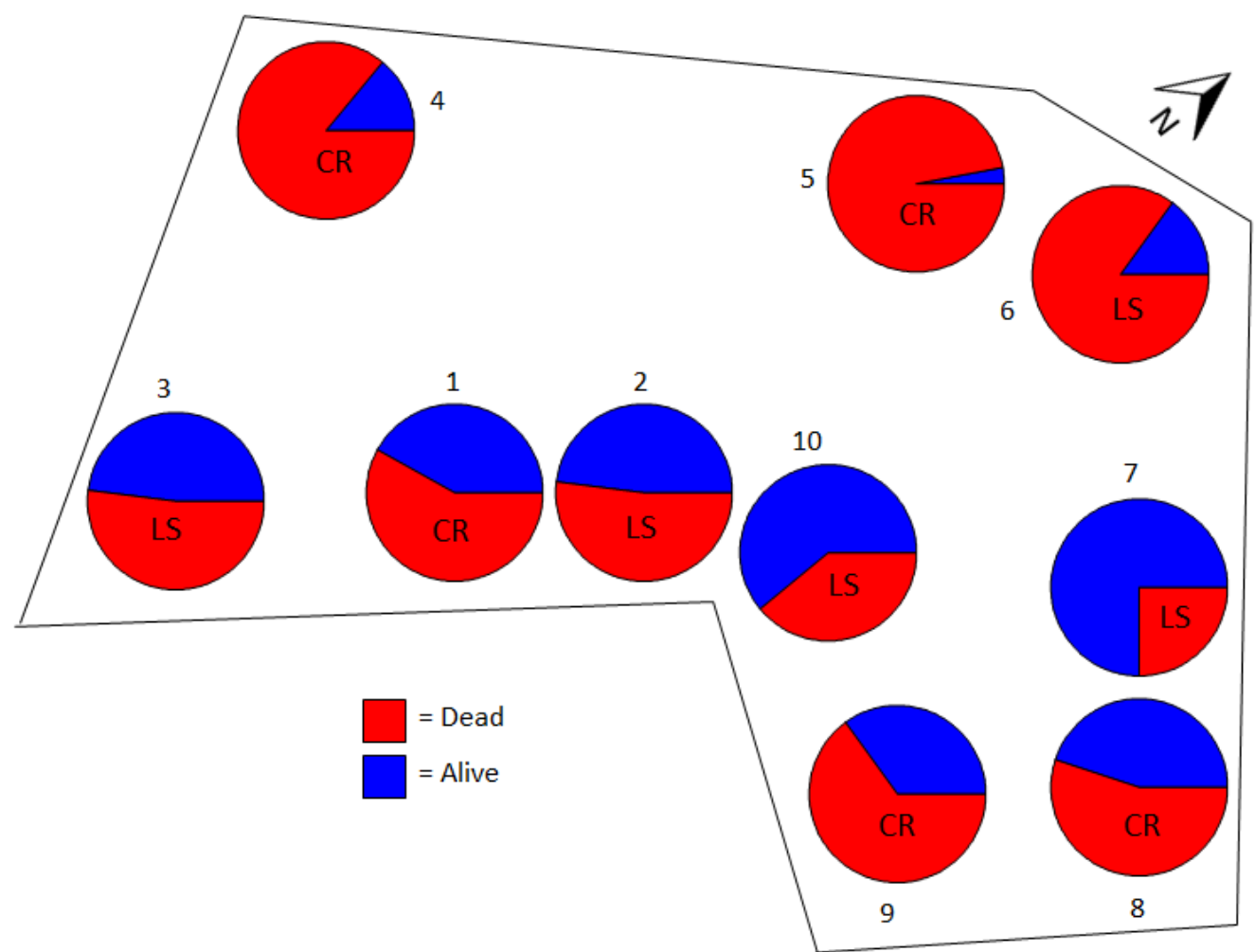

Figure 26 Pie graphs showing proportion of C. robusta (CR) and L. scoparium (LS) surviving in blocks 1-10 at Wairio Wetland after 30 months. 


\subsubsection{Survival response to management treatments/site conditions}

\section{Topsoil}

According to Tables 20 and 21, retained topsoil (intact) had a statistically significant negative effect on the survival of $D$. dacrydioides $\left(\mathrm{X}^{2}{ }_{1}=7.58, p<0.01\right)$ and $C$. robusta $\left(\mathrm{X}^{2}{ }_{1}=5.84, p<\right.$ 0.05). This effect was illustrated in Figure 27, where survival of $D$. dacridioides and $C$. robusta after 30 months was higher when topsoil was excavated at $79 \%$ and $28 \%$ respectively compared to when topsoil was retained at $63 \%$ and $25 \%$ respectively. Retained topsoil in interaction with the presence of weedmats had a statistically significant negative effect on survival of $O$. virgata $\left(\mathrm{X}^{2}{ }_{1}=3.85, p<0.05\right)$. Retained topsoil in interaction with increasing percentage of water had a statistically significant positive effect on survival of $C$. robusta $\left(\mathrm{X}^{2}{ }_{1}=5.48, p<0.05\right)$, which is illustrated in Figure 31.

\section{Weedmats}

Figure 28 suggests that the presence or absence of weedmats had little effect on sapling survival over the 30-month period. Results from the linear mixed effects models in Tables 20 and 21 show that the presence of weedmats alone had a statistically significant positive main effect on survival of the focal species $O$. virgata $\left(X^{2}{ }_{1}=5.44, p<0.05\right)$. However, the presence of weedmats in interaction with either the presence of nurse trees $\left(X^{2}{ }_{1}=4.03, p<\right.$ $0.05)$, the retention of topsoil $\left(\mathrm{X}^{2}{ }_{1}=3.85, p<0.05\right)$, or the increasing percentage of water $\left(X^{2}{ }_{1}=5.26, p<0.05\right)$ had a statistically significant negative effect on survival of $O$. virgata. Figures 32-34 illustrate the negative effects of the presence of topsoil, presence of nurse trees and increasing percentage of water, when interacting with the presence of weedmats on survival of $O$. virgata. The presence of weedmats did not have a statistically significant effect on any other species at the site $(p>0.1)$.

\section{Nurse}

Figure 29 suggests survival for all four focal species was greater with the presence of nurse trees (concurrent planting) compared to without nurse trees (no nurse). Table 20 shows that the presence of nurse species had a statistically significant positive main effect on survival of the focal species $C$. australis $\left(\mathrm{X}^{2}{ }_{1}=5.32, p<0.05\right)$ and $D$. dacridioides $\left(\mathrm{X}^{2}{ }_{1}=6.42, p<0.05\right)$. 
Survival of $D$. dacridioides and $C$. australis with the presence of nurse trees was $75 \%$ and $58 \%$ respectively compared to the absence of nurse trees at $66 \%$ and $43 \%$ respectively (Figure 29). However, the presence of nurse species in interaction with increasing percentage of water had a significant negative effect on survival of $D$. dacrydioides $\left(\mathrm{X}^{2}{ }_{1}=\right.$ $5.68, p<0.05)$ and Olearia Virgata $\left(\mathrm{X}^{2}{ }_{1}=5.26, p<0.05\right)$ which is illustrated in Figures 33 and 35.

\section{Nurse spacing}

Table 21 indicates that $1.5 \mathrm{~m}$ spacing of nurse trees had a statistically significant positive main effect on survival of L. scoparium $\left(\mathrm{X}^{2}{ }_{1}=11.59, p<0.001\right)$, C. propinqua $\left(\mathrm{X}^{2}{ }_{1}=8.36, p<\right.$ $0.005)$, and $P$. tenuifolium $\left(\mathrm{X}^{2}{ }_{1}=4.35, p<0.05\right)$ compared to $0.75 \mathrm{~m}$ spacing. Figure 30 illustrates these effects with higher survival of L. scoparium, C. propinqua and P. tenuifolium after 30 months when planted $1.5 \mathrm{~m}$ apart at $63 \%, 33 \%$ and $62 \%$ respectively compared to when planted $0.75 \mathrm{~m}$ apart at $36 \%, 16 \%$ and $36 \%$ respectively.

\section{Water}

The linear mixed effects models shown in Tables 20 and 21 indicate that waterlogging had a detrimental impact on the survival of the majority of species planted at Wairio. Increasing percentage of water (waterlogging) had a statistically significant negative main effect on survival of the focal species $P$. totara $\left(\mathrm{X}^{2}{ }_{1}=28.95, p<0.0001\right)$ and the nurse species; $C$. robusta $\left(\mathrm{X}^{2}{ }_{1}=17.43, p<0.0001\right)$, Pittosporum tenuifolium $\left(\mathrm{X}^{2}{ }_{1}=21.50, p<0.0001\right), \mathrm{L}$. scoparium $\left(\mathrm{X}^{2}{ }_{1}=12.33, p<0.001\right)$ and $C$. propinqua $\left(\mathrm{X}^{2}{ }_{1}=4.33, p<0.05\right)$. 
Table 20 Linear mixed effects model of focal tree 30-month survival in response to various management treatments and site conditions (* indicates a significant $\mathrm{p}$-value: $\left.{ }^{*}<0.05, * *<0.01, * * *<0.001\right)$. Individual terms are based on analysis of deviance using type 3 tests. The effect of nurse spacing was not included as a treatment at this stage as all focal trees were spaced $1.5 \mathrm{~m}$ (advance planting in the future will mean different spacing).

\begin{tabular}{|c|c|c|c|c|c|c|c|c|}
\hline \multirow[t]{2}{*}{ Treatments/ conditions } & \multicolumn{2}{|c|}{$\begin{array}{c}\text { C. australis } \\
n=80\end{array}$} & \multicolumn{2}{|c|}{$\begin{array}{l}\text { D. dacrydioides } \\
\qquad n=114\end{array}$} & \multicolumn{2}{|c|}{$\begin{array}{l}\text { O. virgata } \\
n=80\end{array}$} & \multicolumn{2}{|c|}{$\begin{array}{c}\text { P. totara } \\
n=70\end{array}$} \\
\hline & Beta coeff. & $p$-value & Beta coeff. & $p$-value & Beta coeff. & $p$-value & Beta coeff. & $p$-value \\
\hline Topsoil intact & 0.867 & 0.0738 & -1.937 & $0.0059 * *$ & 1.314 & 0.0930 & -0.835 & 0.0557 \\
\hline Weedmat present & 0.303 & 0.4341 & -0.223 & 0.5765 & 2.089 & $0.0197^{*}$ & 0.171 & 0.6877 \\
\hline Nurse present & 1.401 & $0.0211^{*}$ & 1.705 & $0.0113^{*}$ & 0.976 & 0.1163 & -0.122 & 0.7803 \\
\hline Water \% & -0.009 & 0.4951 & 0.015 & 0.3724 & -0.022 & 0.1508 & -0.106 & $0.0000 * * *$ \\
\hline Topsoil x weedmat & - & - & - & - & -1.733 & $0.0496 *$ & - & - \\
\hline Topsoil x water & - & - & 0.039 & 0.0548 & -0.041 & 0.1063 & - & - \\
\hline Weedmat $\mathrm{x}$ water & - & - & - & - & -0.064 & $0.0219 *$ & - & - \\
\hline Nurse $\mathrm{x}$ weedmat & - & - & - & - & -1.756 & $0.0447^{*}$ & - & - \\
\hline Nurse $\mathrm{x}$ water & -0.034 & 0.0920 & -0.047 & $0.0171^{*}$ & - & - & - & - \\
\hline
\end{tabular}


Table 21 Linear mixed effects model of nurse tree 30-month survival in response to various management treatments and site conditions (* indicates a significant $\mathrm{p}$-value: $\left.{ }^{*}<0.05, * *<0.01, * * *<0.001\right)$. Individual terms are based on analysis of deviance using type 3 tests.

\begin{tabular}{|c|c|c|c|c|c|c|c|c|}
\hline \multirow[t]{2}{*}{ Treatments/ conditions } & \multicolumn{2}{|c|}{$\begin{array}{c}\text { C. robusta } \\
n=112\end{array}$} & \multicolumn{2}{|c|}{$\begin{array}{c}\text { C. propinqua } \\
n=130\end{array}$} & \multicolumn{2}{|c|}{$\begin{array}{l}\text { P. tenuifolium } \\
\quad n=190\end{array}$} & \multicolumn{2}{|c|}{$\begin{array}{l}\text { L. scoparium } \\
\qquad \begin{array}{l}n=242\end{array}\end{array}$} \\
\hline & Beta coeff. & $\mathrm{p}$-value & Beta coeff. & $\mathrm{p}$-value & Beta coeff. & $p$-value & Beta coeff. & $p$-value \\
\hline Topsoil intact & -1.351 & $0.0156^{*}$ & 0.252 & 0.3962 & -0.238 & 0.4240 & -0.257 & 0.2594 \\
\hline Weedmat present & -0.192 & 0.4604 & -0.050 & 0.8379 & 0.249 & 0.3299 & 0.038 & 0.8705 \\
\hline Spacing 1.5 & -0.477 & 0.4427 & 1.290 & $0.0038 * *$ & 0.793 & $0.0369 *$ & 0.975 & $0.0007 * * *$ \\
\hline Water \% & -0.078 & $0.0000 * * *$ & -0.026 & $0.0374^{*}$ & -0.099 & $0.0000 * * *$ & -0.047 & $0.0004 * * *$ \\
\hline Topsoil $x$ water & 0.063 & $0.0193^{*}$ & - & - & - & - & - & - \\
\hline
\end{tabular}



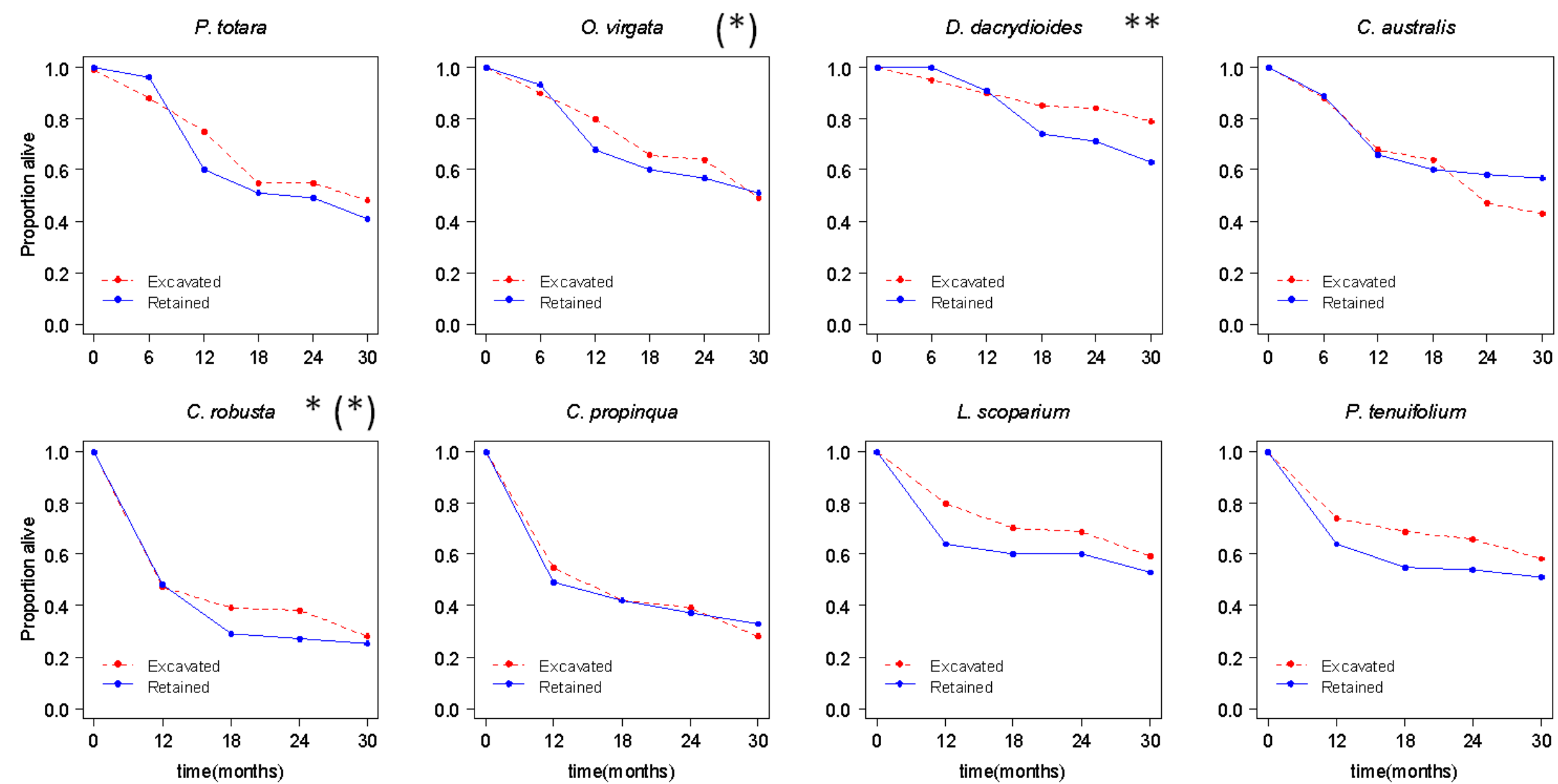

Figure 27 Proportion of focal and nurse species populations alive over time in response to the topsoil treatment (excavated, retained). Focal species are shown on the top row, nurse species shown below. Nurse species survival was not recorded at the 6 month mark. An asterisk indicates a significant main effect of topsoil on that species ( $\mathrm{p}$-value: $\left.{ }^{*}<0.05, * *<0.01, * * *<0.001\right)$. An asterisk in brackets ( $\left.{ }^{*}\right)$ indicates a significant effect of topsoil on that species when in interaction with another factor (see tables 20-21 and figures 31-32). 

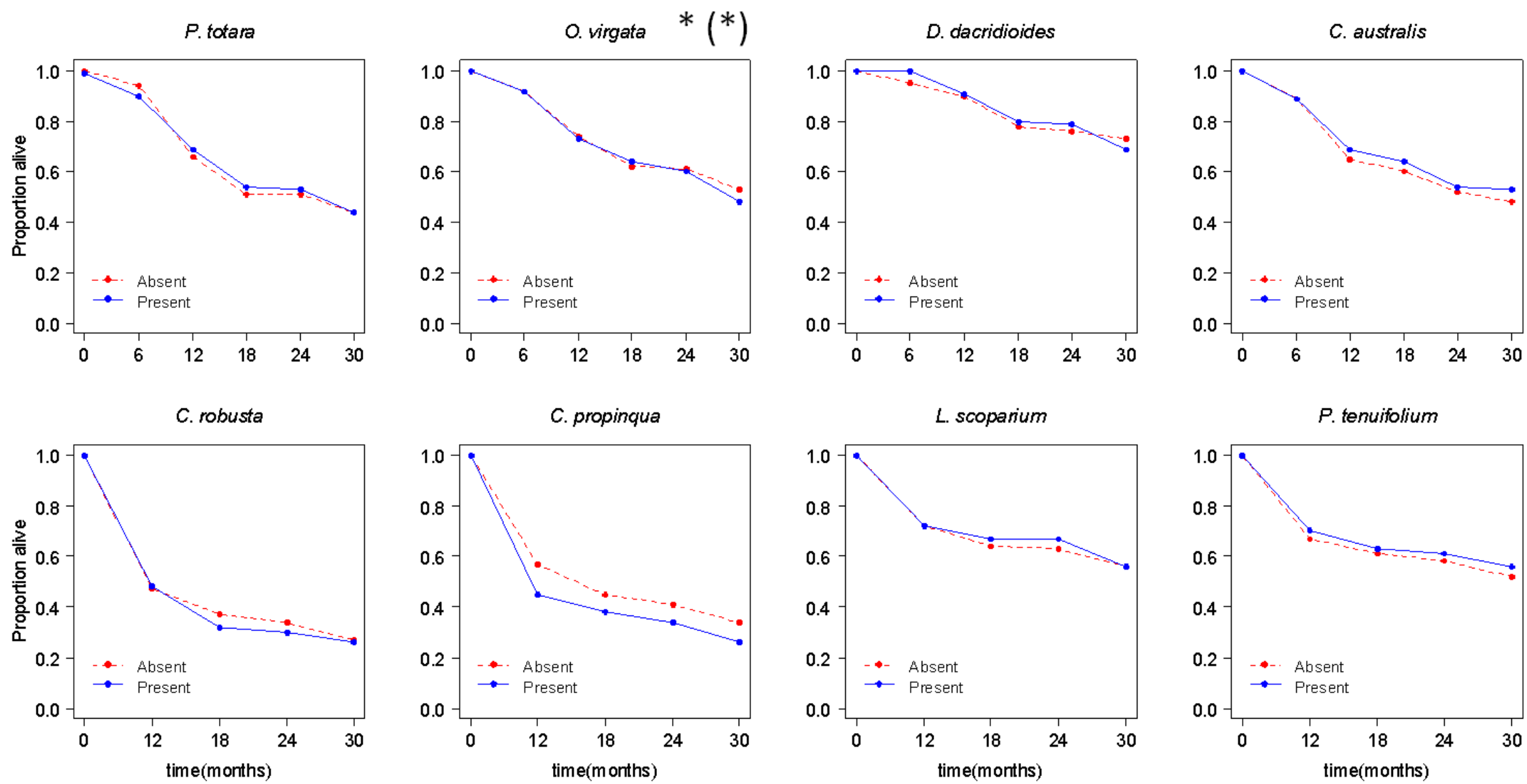

Figure 28 Proportion of focal and nurse species populations alive over time in response to the presence or absence of weedmats. Focal species are shown on the top row, nurse species shown below. Nurse species survival was not recorded at the 6 month mark. An asterisk indicates a significant main effect of weedmats on that species (p-value: $*<0.05, * *<0.01, * * *<0.001)$. An asterisk in brackets $(*)$ indicates a significant effect of weedmats on that species when in interaction with another factor (see table 20 and figure 34). 
P. totara

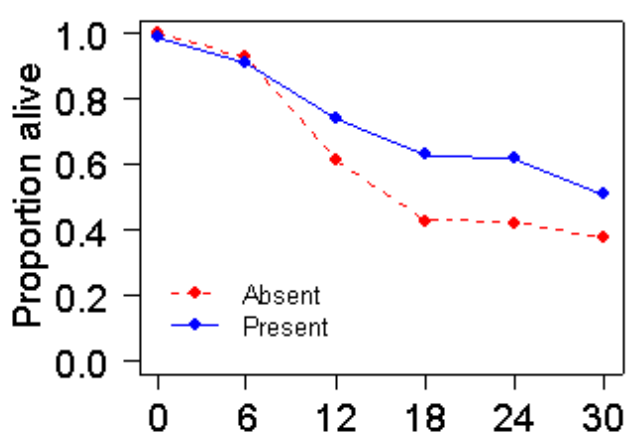

D. dacrydioides $*(*)$

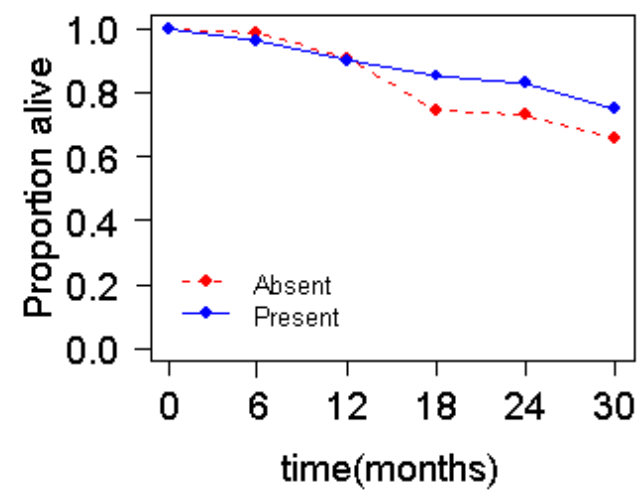

O. virgata

$(*)$

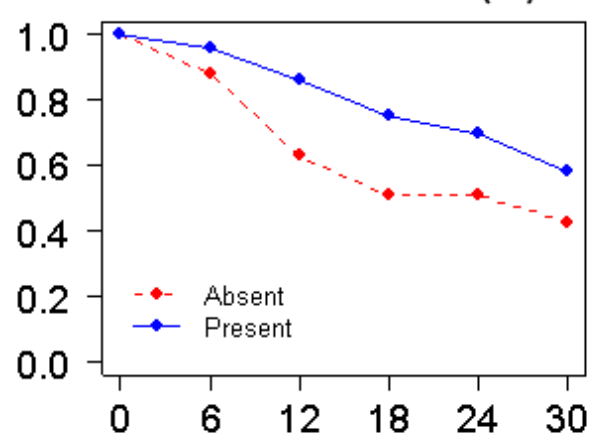

C. australis *

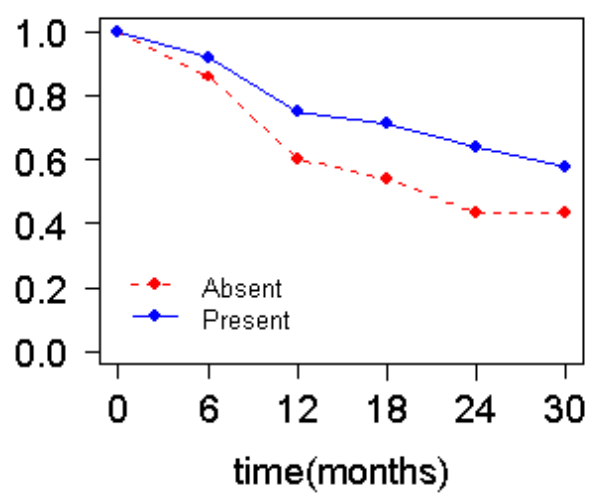

Figure 29 Proportion of focal species alive over time in response to the presence or absence of nurse trees. An asterisk indicates a significant main effect of nurse trees on that species (p-value: $\left.{ }^{*}<0.05, * *<0.01, * * *<0.001\right)$. An asterisk in brackets $(*)$ indicates a significant effect of nurse trees on that species when in interaction with another factor (see table 20, figure 33 and figure 35$)$. 
C. robusta

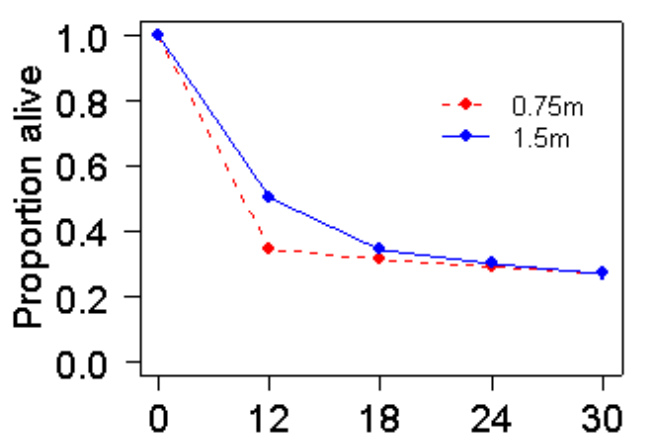

L. scoparium

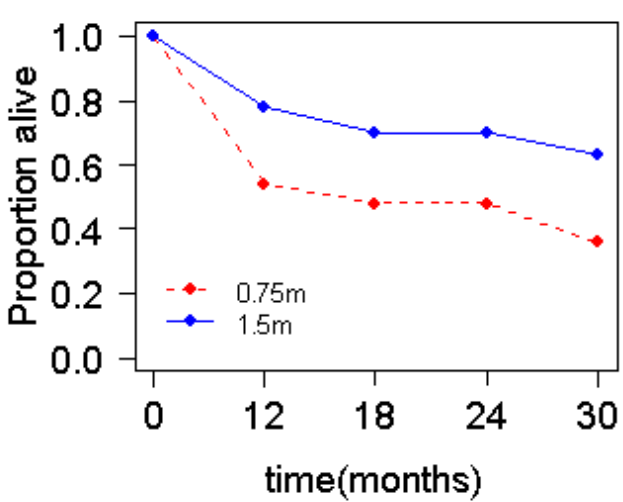

C. propinqua

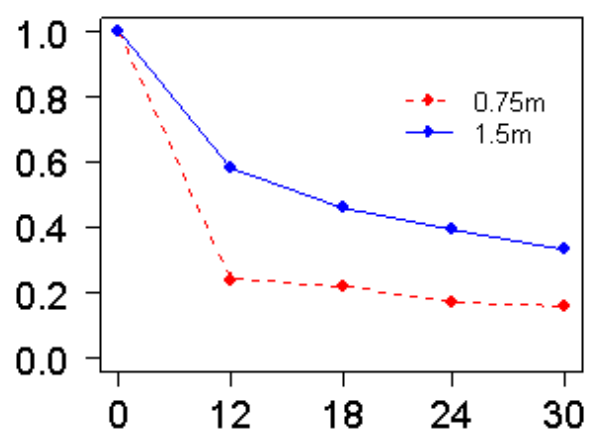

P. tenuifolium

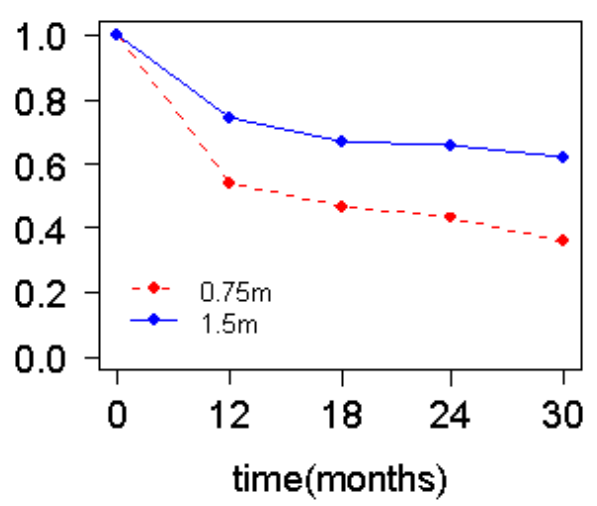

Figure 30 Proportion of nurse species alive over time in response to spacing treatment $(0.75 \mathrm{~m}, 1.5 \mathrm{~m})$. An asterisk indicates a significant main effect of spacing on that species ( $p$ value: $\left.{ }^{*}<0.05, * *<0.01, * * *<0.001\right)$. 

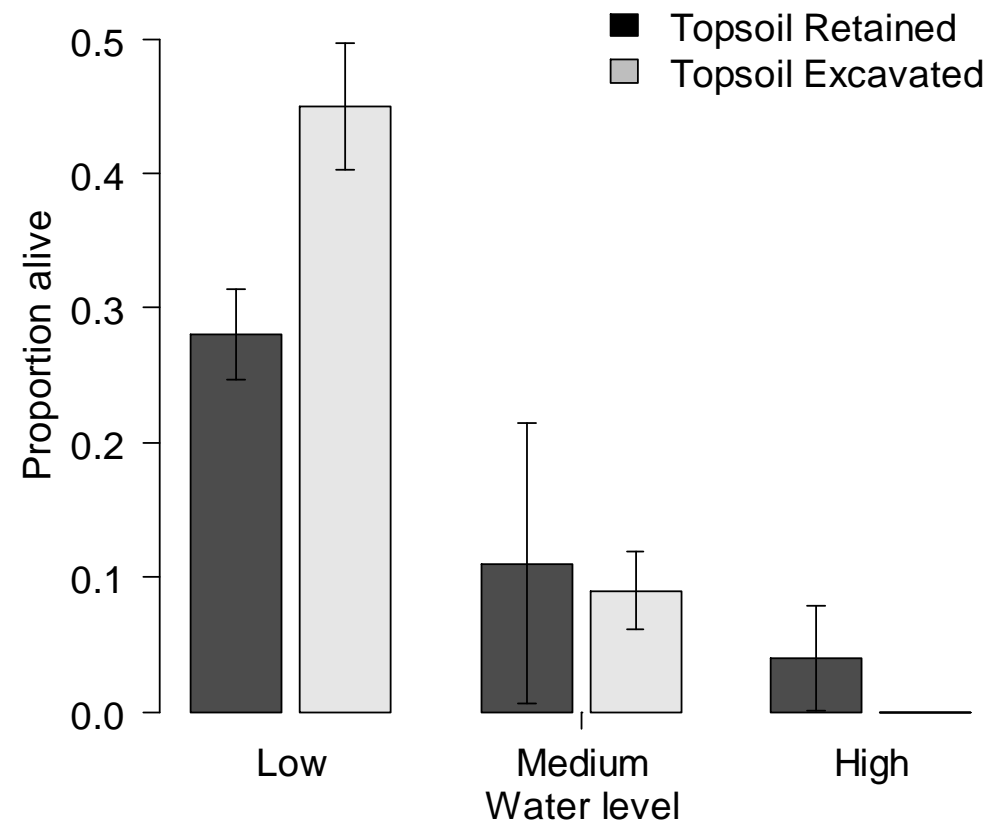

Figure 31 Proportion of $C$. robusta alive in response to the combination of percent water (low $=0-20 \%$, medium $=21-40 \%$, high $=41-60 \%)$ averaged over the study period and topsoil removal (excavated/retained). The interaction between these two treatments was significant $(p<0.05)$ (Refer to table 21). Standard error bars are shown.
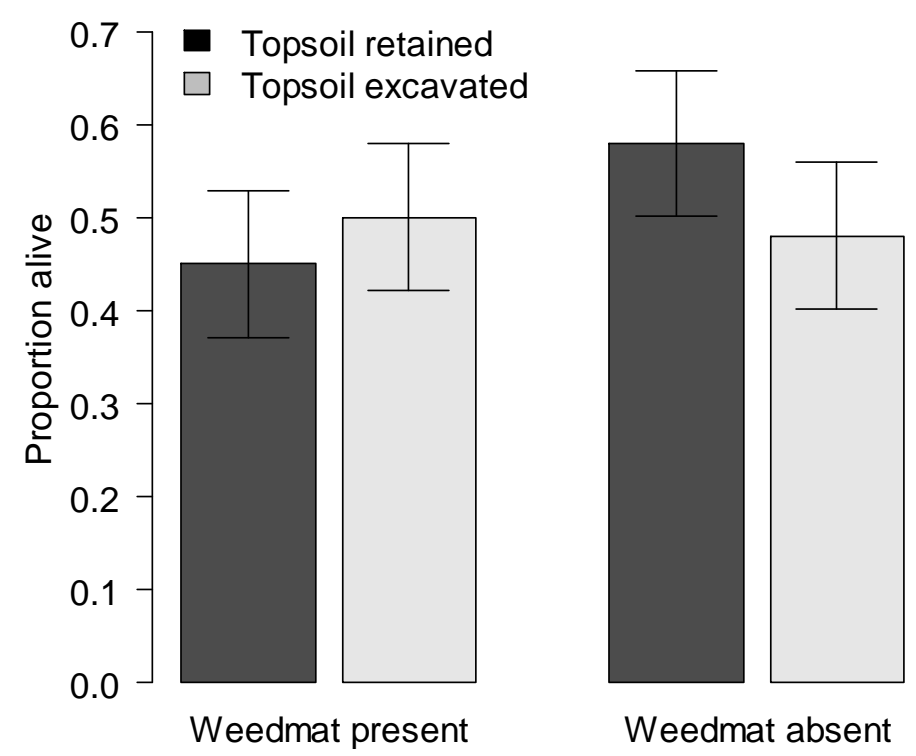

Figure 32 Proportion of $O$. virgata alive in response to the combination of weedmat (present/absent) and topsoil removal (excavated/retained). The interaction between these two treatments was significant $(p<0.05)$ (Refer to table 20). Standard error bars are shown. 


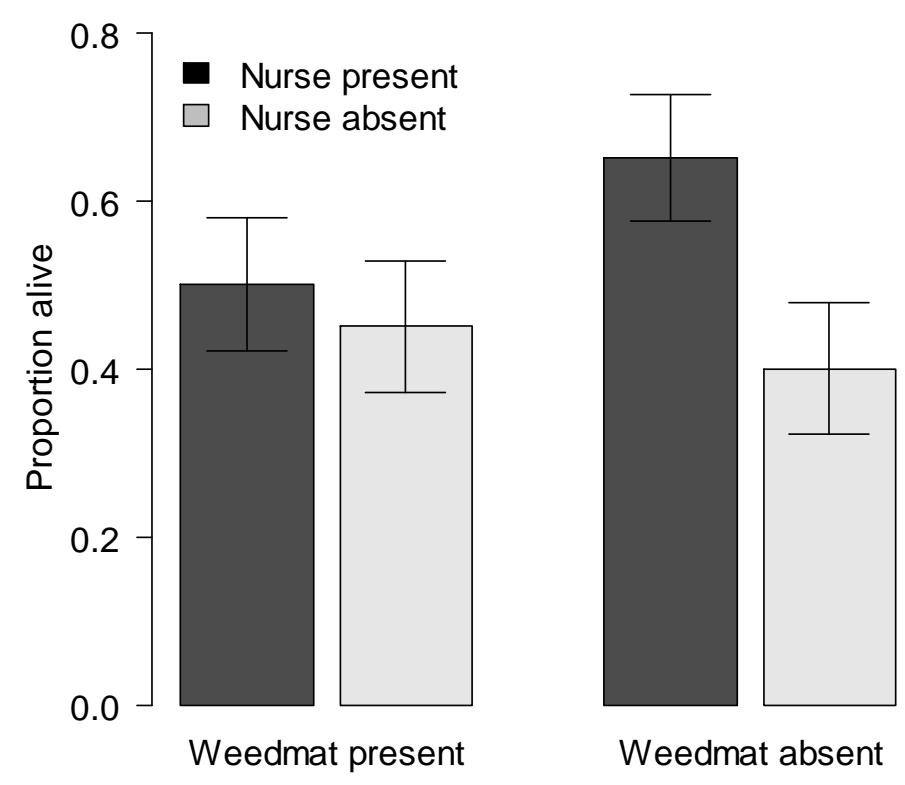

Figure 33 Proportion of $O$. virgata alive in response to the combination of weedmat (present/absent) and nurse presence (nurse/no nurse). The interaction between these two treatments was significant $(p<0.05)$ (Refer to table 20). Standard error bars are shown.

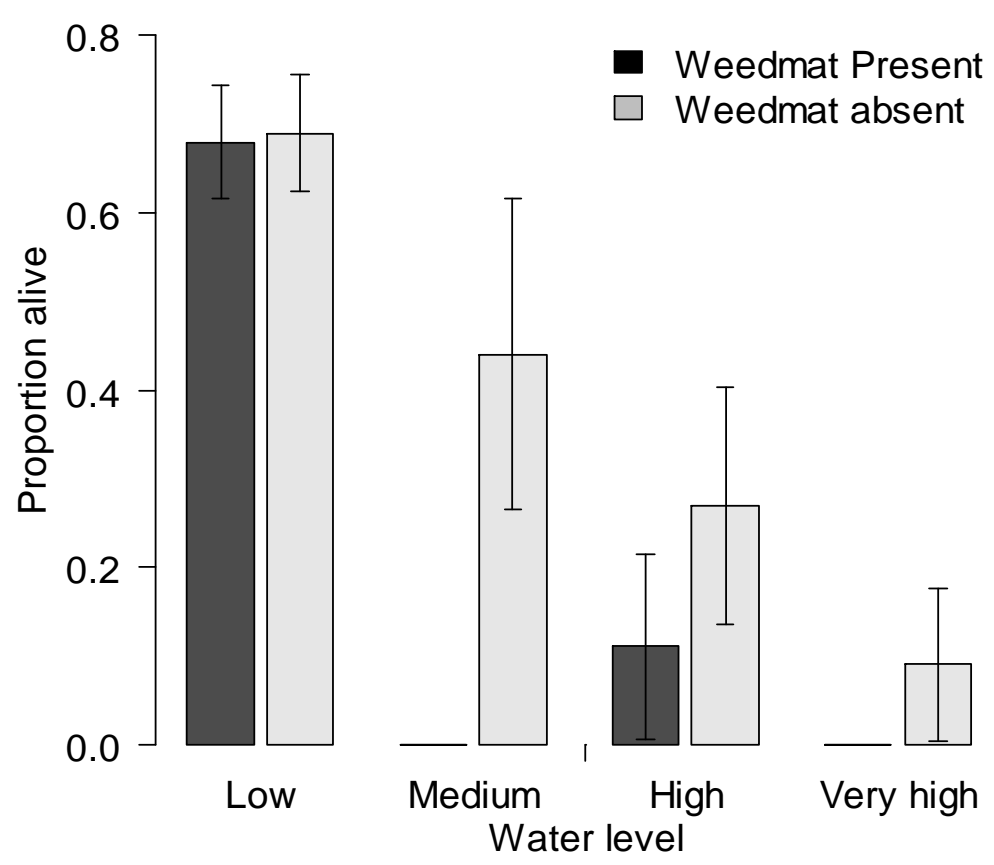

Figure 34 Proportion of 0 . virgata alive in response to the combination of percent water (low $=0-20 \%$, medium $=21-40 \%$, high $=41-60 \%$, very high $=61 \%+$ water ) averaged over the study period and weedmat (weedmat/no weedmat). The interaction between these two treatments was significant $(p<0.05)$ (Refer to table 20). Standard error bars are shown. 


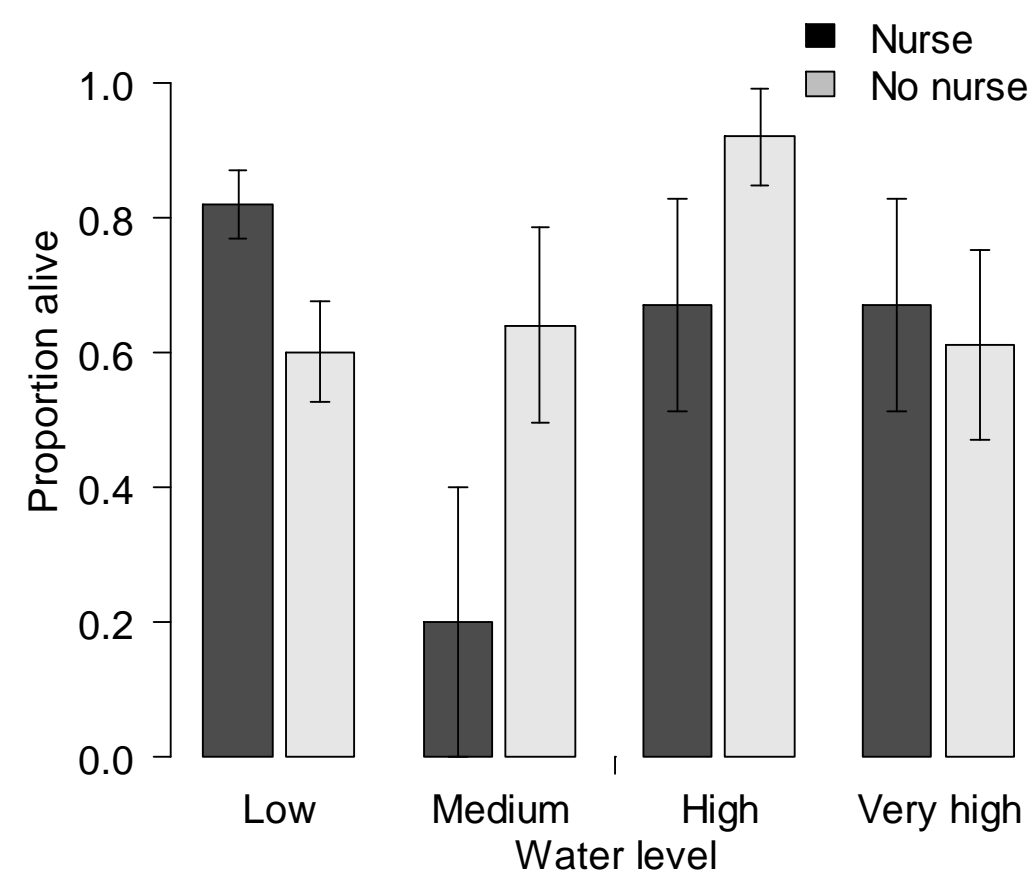

Figure 35 Proportion of $D$. dacridioides alive in response to the combination of water level (low $=0-20 \%$, medium $=21-40 \%$, high $=41-60 \%$, very high $=61 \%+$ water ) averaged over the study period and nurse presence (nurse/no nurse). The interaction between these two treatments was significant $(p<0.05)$ (Refer to table 20). Standard error bars are shown. 


\subsubsection{Cost-benefit analysis of management treatments}

Appendix 3.6.4 shows the cost of various management treatments. The cheapest management option for all species was intact topsoil (no excavation), no weedmats, and no nurse trees at an average cost of $\$ 3.66$ per tree (Table 22). The management treatments promoting the greatest plant survival varied between species, however excavation of topsoil, combined with nurse tree planting, $1.5 \mathrm{~m}$ spacing and no weedmats promoted the greatest survival of focal species at an average cost of $\$ 12.41$ per tree (Table 23). The combination of topsoil excavation, $1.5 \mathrm{~m}$ spacing, and weedmats promoted the greatest survival of nurse species at an average cost of $\$ 6.04$ per tree.

Table 24 shows a cost benefit analysis of each tree species and corresponding management treatments, for one tree to survive until 30 months after planting. The most cost-effective management treatment combination is L. scoparium with intact topsoil, no nurse trees, no weedmats and $1.5 \mathrm{~m}$ spacing; the cost per surviving trees is $\$ 5.14$. The least cost-effective combination is $P$. totara with topsoil excavation, nurse trees, weedmats and $1.5 \mathrm{~m}$ spacing; the cost per surviving tree is $\$ 28.58$. Leptospermum scoparium was the most cost-effective species, with an average cost of $\$ 9.87$ per surviving tree. Podocarpus totara was the least cost-effective species, with an average cost of $\$ 20.05$ per surviving tree. The most successful management treatment combination was intact topsoil with weedmats and nurse trees at $1.5 \mathrm{~m}$ spacing, with an average cost of $\$ 8.82$ per surviving tree. The least successful treatment combination was topsoil excavation, with nurse trees, weedmats and $1.5 \mathrm{~m}$ spacing, with an average cost of $\$ 26.43$ per surviving tree. 
Table 22 Cost of each tree species (NZD) per management treatment combination. Labour costs from volunteers planting trees and the organisation of the experiment were not factored into the cost of each tree. Annual release spraying was undertaken in 2012,2013 and 2014 at a total cost of $\$ 0.90$ per tree. Those trees without weedmats were initially spot sprayed (\$0.29 per tree). Trees in blocks with intact topsoil had initial release spraying ( $\$ 0.29$ per tree). Four nurse trees were planted around each focal tree $(\$ 8.10$ per focal tree). The cheapest management treatments for each species have been bolded.

\begin{tabular}{|c|c|c|c|c|c|c|c|c|c|}
\hline Management treatment & $\begin{array}{l}\text { D. dacridioides } \\
\text { (\$) }\end{array}$ & $\begin{array}{c}\text { C. australis } \\
\text { (\$) }\end{array}$ & $\begin{array}{l}\text { O. virgata } \\
\text { (\$) }\end{array}$ & $\begin{array}{c}\text { P. totara } \\
\text { (\$) }\end{array}$ & $\begin{array}{c}\text { C. robusta } \\
\text { (\$) }\end{array}$ & $\begin{array}{c}\text { C. propinqua } \\
\text { (\$) }\end{array}$ & $\begin{array}{c}\text { L. scoparium } \\
\text { (\$) }\end{array}$ & $\begin{array}{l}\text { P. tenuifolium } \\
\text { (\$) }\end{array}$ & Average \\
\hline Excavated, nurse & 12.41 & 12.41 & 12.41 & 12.41 & NA & NA & NA & NA & 12.41 \\
\hline Excavated, nurse, weedmat & 14.29 & 14.29 & 14.29 & 14.29 & NA & NA & NA & NA & 12.41 \\
\hline Excavated, no nurse & 4.31 & 4.31 & 4.31 & 4.31 & 4.53 & 4.53 & 3.48 & 3.48 & 4.16 \\
\hline Excavated, no nurse, weedmat & 6.19 & 6.19 & 6.19 & 6.19 & 6.41 & 6.41 & 5.36 & 5.36 & 6.04 \\
\hline Intact, nurse & 11.91 & 11.91 & 11.91 & 11.91 & NA & NA & NA & NA & 11.91 \\
\hline Intact, nurse, weedmat & 13.79 & 13.79 & 13.79 & 13.79 & NA & NA & NA & NA & 13.79 \\
\hline Intact, no nurse & 3.81 & 3.81 & 3.81 & 3.81 & 4.03 & 4.03 & 2.98 & 2.98 & 3.66 \\
\hline Intact, no nurse, weedmat & 5.69 & 5.69 & 5.69 & 5.69 & 5.91 & 5.91 & 4.86 & 4.86 & 5.54 \\
\hline Average & 9.05 & 9.05 & 9.05 & 9.05 & 5.22 & 5.22 & 4.17 & 4.17 & \\
\hline
\end{tabular}


Table 23 Survival (Proportion alive) of each species per management treatment combination, 30 months after planting. Only nurse species were spaced $0.75 \mathrm{~m}$ apart. Management treatments promoting the greatest survival for each species have been bolded.

\begin{tabular}{|c|c|c|c|c|c|c|c|c|c|}
\hline Management treatment & D. dacridioides & C. australis & O. virgata & P. totara & C. robusta & C. propinqua & L. scoparium & P. tenuifolium & Average \\
\hline Excavated, nurse, $1.5 \mathrm{~m}$ spacing & 0.50 & 0.80 & 0.60 & 0.60 & NA & NA & NA & NA & 0.63 \\
\hline Excavated, nurse, weedmat, $1.5 \mathrm{~m}$ spacing & 0.50 & 0.85 & 0.45 & 0.50 & NA & NA & NA & NA & 0.58 \\
\hline Excavated, no nurse, $0.75 \mathrm{~m}$ spacing & NA & NA & NA & NA & 0.00 & 0.00 & 0.22 & 0.25 & 0.12 \\
\hline Excavated, no nurse, $1.5 \mathrm{~m}$ spacing & 0.35 & 0.75 & 0.35 & 0.40 & 0.35 & 0.36 & 0.67 & 0.59 & 0.48 \\
\hline Excavated, no nurse, weedmat, $0.75 \mathrm{~m}$ spacing & NA & NA & NA & NA & 0.00 & 0.00 & 0.31 & 0.25 & 0.14 \\
\hline Excavated, no nurse, weedmat, $1.5 \mathrm{~m}$ spacing & 0.35 & 0.75 & 0.55 & 0.40 & 0.28 & 0.27 & 0.71 & 0.71 & 0.50 \\
\hline Intact, nurse, $1.5 \mathrm{~m}$ spacing & 0.60 & 0.75 & 0.70 & 0.38 & NA & NA & NA & NA & 0.61 \\
\hline Intact, nurse, weedmat, $1.5 \mathrm{~m}$ spacing & 0.70 & 0.60 & 0.55 & 0.55 & NA & NA & NA & NA & 0.60 \\
\hline Intact, no nurse, $0.75 \mathrm{~m}$ spacing & NA & NA & NA & NA & 0.41 & 0.31 & 0.46 & 0.50 & 0.42 \\
\hline Intact, no nurse, $1.5 \mathrm{~m}$ spacing & 0.45 & 0.60 & 0.45 & 0.40 & 0.18 & 0.36 & 0.58 & 0.54 & 0.45 \\
\hline Intact, no nurse, weedmat, $0.75 \mathrm{~m}$ spacing & NA & NA & NA & NA & 0.40 & 0.17 & 0.38 & 0.40 & 0.34 \\
\hline Intact, no nurse, weedmat, $1.5 \mathrm{~m}$ spacing & 0.55 & 0.55 & 0.35 & 0.30 & 0.22 & 0.34 & 0.56 & 0.56 & 0.43 \\
\hline
\end{tabular}


Table 24 Cost-benefit analysis (cost per surviving tree in NZD) of each species per management treatment combination, 30 months after planting. Labour costs were excluded from the analysis. The most cost-effective management treatments for each species have been bolded. $\mathrm{CNBC}=$ values could not be calculated due to zero survival.

\begin{tabular}{|c|c|c|c|c|c|c|c|c|c|}
\hline Management treatment & $\begin{array}{l}\text { D. dacridioides } \\
\text { (\$) }\end{array}$ & $\begin{array}{c}\text { C. australis } \\
\text { (\$) }\end{array}$ & $\begin{array}{l}\text { O. virgata } \\
\text { (\$) }\end{array}$ & $\begin{array}{c}\text { P. totara } \\
\text { (\$) }\end{array}$ & $\begin{array}{c}\text { C. robusta } \\
\text { (\$) }\end{array}$ & $\begin{array}{c}\text { C. propinqua } \\
\text { (\$) }\end{array}$ & $\begin{array}{l}\text { L. scoparium } \\
\text { (\$) }\end{array}$ & $\begin{array}{l}\text { P. tenuifolium } \\
\text { (\$) }\end{array}$ & Average \\
\hline Excavated, nurse, $1.5 \mathrm{~m}$ spacing & 24.82 & 15.51 & 20.68 & 20.68 & NA & NA & NA & NA & 20.42 \\
\hline Excavated, nurse, weedmat $1.5 \mathrm{~m}$ spacing & 28.58 & 16.81 & 31.76 & 28.58 & NA & NA & NA & NA & 26.43 \\
\hline Excavated, no nurse, $0.75 \mathrm{~m}$ spacing & NA & NA & NA & NA & CNBC & CNBC & 15.82 & 13.92 & 14.87 \\
\hline Excavated, no nurse, $1.5 \mathrm{~m}$ spacing & 12.31 & 5.75 & 12.31 & 10.78 & 12.94 & 12.58 & 5.19 & 5.90 & 9.72 \\
\hline Excavated, no nurse, weedmat, $0.75 \mathrm{~m}$ spacing & NA & NA & NA & NA & CNBC & CNBC & 17.29 & 21.44 & 19.37 \\
\hline Excavated, no nurse, weedmat, $1.5 \mathrm{~m}$ spacing & 17.69 & 8.25 & 11.25 & 15.48 & 22.89 & 23.74 & 7.55 & 7.55 & 14.3 \\
\hline Intact, nurse, $1.5 \mathrm{~m}$ spacing & 19.85 & 15.88 & 17.01 & 31.34 & NA & NA & NA & NA & 21.02 \\
\hline Intact, nurse, weedmat, $1.5 \mathrm{~m}$ spacing & 19.70 & 22.98 & 25.07 & 25.07 & NA & NA & NA & NA & 23.2 \\
\hline Intact, no nurse, $0.75 \mathrm{~m}$ spacing & NA & NA & NA & NA & 9.83 & 13.00 & 6.48 & 5.96 & 8.82 \\
\hline Intact, no nurse, $1.5 \mathrm{~m}$ spacing & 8.47 & 6.35 & 8.47 & 9.53 & 22.39 & 11.19 & 5.14 & 5.52 & 9.63 \\
\hline Intact, no nurse, weedmat, $0.75 \mathrm{~m}$ spacing & NA & NA & NA & NA & 14.78 & 34.76 & 12.79 & 12.15 & 18.62 \\
\hline Intact, no nurse, weedmat, $1.5 \mathrm{~m}$ spacing & 10.35 & 10.35 & 16.26 & 18.97 & 26.86 & 17.38 & 8.68 & 8.68 & 14.69 \\
\hline Average & 17.72 & 12.74 & 17.85 & 20.05 & 13.71 & 14.08 & 9.87 & 10.14 & \\
\hline
\end{tabular}




\subsubsection{Plant growth}

Figure 36 shows the growth of each species over the 30 month study period. During this period the height of the focal species, C. australis increased by $20.8 \mathrm{~cm} / \mathrm{yr}$. Podocarpus totara and $O$. virgata had relatively similar growth rates across this period increasing by $11.7 \mathrm{~cm} / \mathrm{yr}$ and $9.8 \mathrm{~cm} / \mathrm{yr}$ respectively. Dacrycarpus dacridioides had little growth within this period increasing by $4.2 \mathrm{~cm} / \mathrm{yr}$.

Heights of nurse species were only measured between July 2012 and January 2014. During this time $L$. scoparium and $P$. tenuifolium had high growth rates increasing by $29.3 \mathrm{~cm} / \mathrm{yr}$ and $27.9 \mathrm{~cm} / \mathrm{yr}$ respectively, whereas C. propinqua and C. robusta had lower growth rates, increasing by $15.9 \mathrm{~cm} / \mathrm{yr}$ and $14.4 \mathrm{~cm} / \mathrm{yr}$ respectively. 

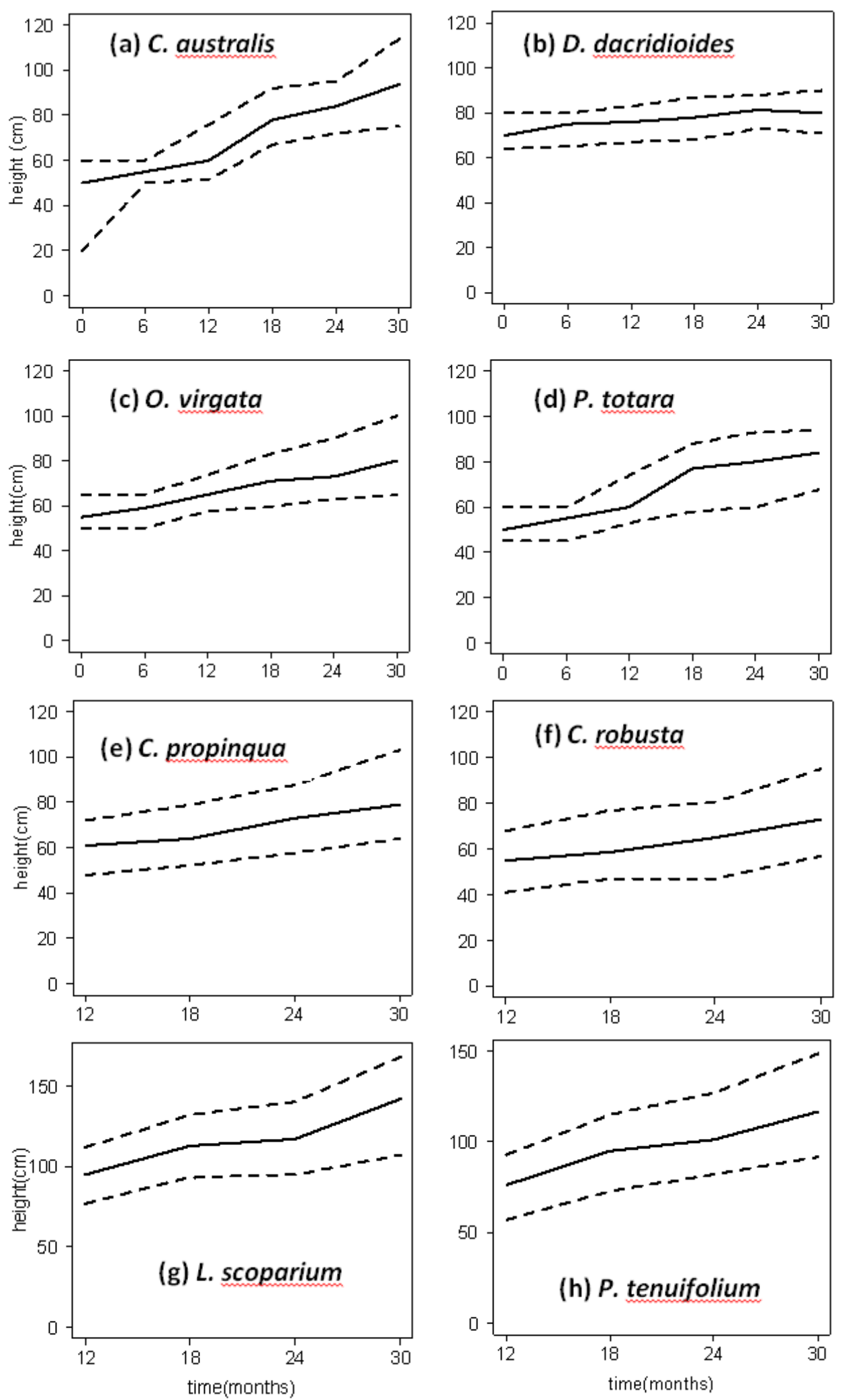

Figure 36 Growth $(\mathrm{cm})$ of each species over the 30 -month period. The median height is a solid line, with lower $25 \%$ and upper $75 \%$ quartiles as a dashed line. Height of nurse trees was not recorded until 12 months after planting. 


\subsubsection{Plant height distributions}

Figure 37 indicates the large variability in plant height for each species at Wairio Wetland after 30 months of growth. Leptospermum scoparium had the highest median plant height at $142 \mathrm{~cm}$. Leptospermum scoparium also had the greatest variation in plant heights compared to other species with a minimum of $40 \mathrm{~cm}$ and maximum height of $231 \mathrm{~cm}$. Dacrycarpus dacridioides and $P$. totara had the smallest variation in plant heights compared to other species with a minimum of $49 \mathrm{~cm}$ and $41 \mathrm{~cm}$ respectively and a maximum of $123 \mathrm{~cm}$ and $115 \mathrm{~cm}$ respectively.

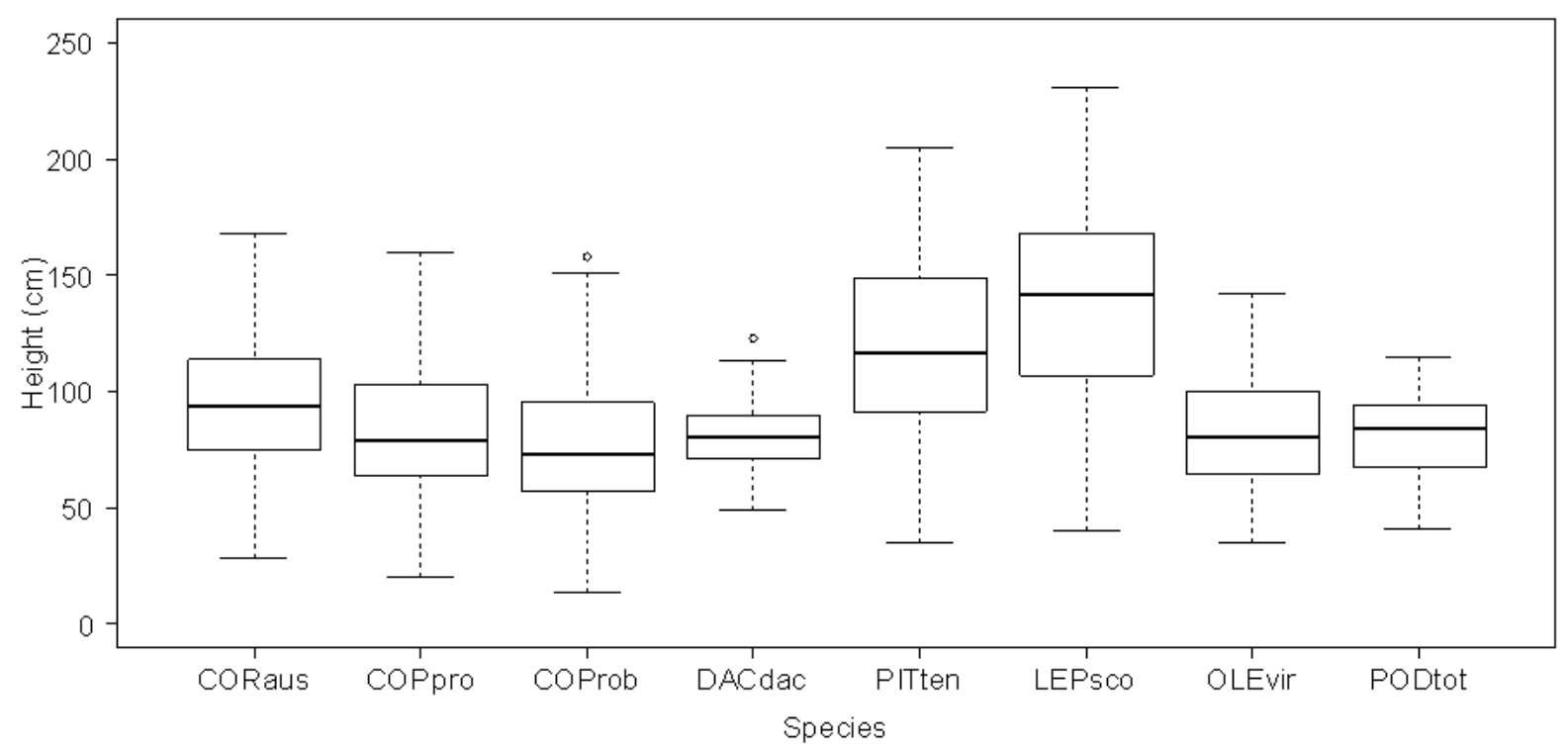

Figure 37 Boxplots showing plant height distributions of each species 30 months after planting. Focal species are represented as CORaus $=C$. australis, DACdac $=D$. dacrydioides, OLEvir $=O$. virgata, PODtot $=P$. totara. Nurse species are represented as COPpro $=C$. propinqua, $\mathrm{COProb}=\mathrm{C}$. robusta, PITten $=$ P. tenuifolium, LEPsco $=$ L. scoparium . 


\subsubsection{Growth response to management treatments/site conditions}

\section{Topsoil}

Tables 25 and 26 indicate that intact topsoil had a statistically significant positive effect on growth of the focal species; C. australis $\left(t_{18}=6.38, p<0.0001\right)$ and 0 . virgata $\left(t_{18}=3.20, p<\right.$ $0.01)$, and the nurse species; L. scoparium $\left(t_{11}=4.61, p<0.001\right)$, P. tenuifolium $\left(t_{8}=4.48, p<\right.$ $0.005)$ and $C$. propinqua $\left(t_{8}=2.99, p<0.05\right)$. The effect of topsoil excavation on plant growth is illustrated in Figure 28.

\section{Weedmat}

The presence of weedmats had a statistically significant negative effect on growth of the focal species $D$. dacridioides $\left(t_{73}=-2.00, p<0.05\right)$, and in contrast a statistically significant positive effect on growth of the nurse species $L$. scoparium $\left(t_{220}=2.20, p<0.05\right)$ as shown in Tables 25 and 26.

\section{Nurse}

Table 25 shows that the planting of nurse trees in between focal trees had a statistically significant positive effect on growth of the focal species $C$. australis $\left(t_{18}=2.10, p<0.05\right)$ and P. totara $\left(t_{17}=2.38, p<0.05\right)$.

\section{Spacing}

Table 26 shows that nurse spacing of $1.5 \mathrm{~m}$ had a statistically significant positive effect on growth of $L$. scoparium $\left(t_{11}=2.74, p<0.05\right)$.

\section{Water}

Increasing percentage of water had a statistically significant negative effect on growth of the focal species; P. totara $\left(t_{42}=-3.26, p>0.005\right)$ and $D$. dacridioides $\left(t_{73}=-2.05, p<0.05\right)$, and the nurse species; $P$. tenuifolium $\left(t_{219}=-2.95, p<0.005\right)$ as shown in Tables 25 and 26 , and illustrated in Figure 39. 
Table 25 Linear mixed effects model of focal tree 30-month growth in response to various management treatments and site conditions (* indicates significant $\mathrm{p}$-value: $\left.{ }^{*}<0.05, * *<0.01, * * *<0.001\right)$. The effect of nurse spacing was not included as a treatment at this stage as all focal trees were spaced $1.5 \mathrm{~m}$ (advance planting in the future will mean different spacing).

\begin{tabular}{|c|c|c|c|c|c|c|c|c|}
\hline \multirow{2}{*}{$\begin{array}{l}\text { Management } \\
\text { treatments }\end{array}$} & \multicolumn{2}{|c|}{ C. australis } & \multicolumn{2}{|c|}{ D. dacrydioides } & \multicolumn{2}{|c|}{ O. virgata } & \multicolumn{2}{|c|}{ P. totara } \\
\hline & Beta coeff. & p-value & Beta coeff. & $p$-value & Beta coeff. & $p$-value & Beta coeff. & $p$-value \\
\hline Topsoil intact & 31.687 & $0.0000 * * *$ & 6.129 & 0.0837 & 17.428 & $0.0050 * *$ & 4.992 & 0.2672 \\
\hline Weedmat present & -0.756 & 0.8742 & -7.073 & $0.0488 *$ & -6.422 & 0.1602 & -4.417 & 0.2568 \\
\hline Nurse present & 10.960 & $0.0501 *$ & 1.135 & 0.7587 & 6.822 & 0.2455 & 10.451 & $0.0291^{*}$ \\
\hline Water \% & -0.306 & 0.0642 & -0.135 & $0.0431 *$ & -0.301 & 0.0822 & -0.777 & $0.0022^{* *}$ \\
\hline Topsoil x water & - & - & -0.159 & 0.1192 & - & - & - & - \\
\hline Weedmat x nurse & - & - & 6.403 & 0.1912 & - & - & - & - \\
\hline
\end{tabular}


Table 26 Linear mixed effects model of nurse tree 30-month growth in response to various management treatments and site conditions (* indicates a significant $\mathrm{p}$-value: $\left.{ }^{*}<0.05, * *<0.01, * * *<0.001\right)$.

\begin{tabular}{|c|c|c|c|c|c|c|c|c|}
\hline \multirow{2}{*}{$\begin{array}{l}\text { Management } \\
\text { treatments }\end{array}$} & \multicolumn{2}{|c|}{ C. robusta } & \multicolumn{2}{|c|}{ C. propinqua } & \multicolumn{2}{|c|}{ P. tenuifolium } & \multicolumn{2}{|c|}{ L. scoparium } \\
\hline & Beta coeff. & $p$-value & Beta coeff. & $p$-value & Beta coeff. & $p$-value & Beta coeff. & $p$-value \\
\hline Topsoil intact & 11.234 & 0.2468 & 20.261 & $0.0172 *$ & 37.957 & $0.0021^{* *}$ & 35.403 & $0.0008 * * *$ \\
\hline Weedmat present & 3.683 & 0.4956 & 3.527 & 0.3937 & 2.236 & 0.6120 & 14.273 & $0.0286^{*}$ \\
\hline Spacing 1.5 & -9.517 & 0.4582 & -17.345 & 0.1624 & 12.306 & 0.3102 & 25.033 & $0.0194^{*}$ \\
\hline Water \% & -0.124 & 0.6708 & 0.267 & 0.2340 & -1.291 & $0.0035 * *$ & -0.192 & 0.5615 \\
\hline Topsoil x weedmat & - & - & - & - & - & - & -13.818 & 0.1509 \\
\hline
\end{tabular}




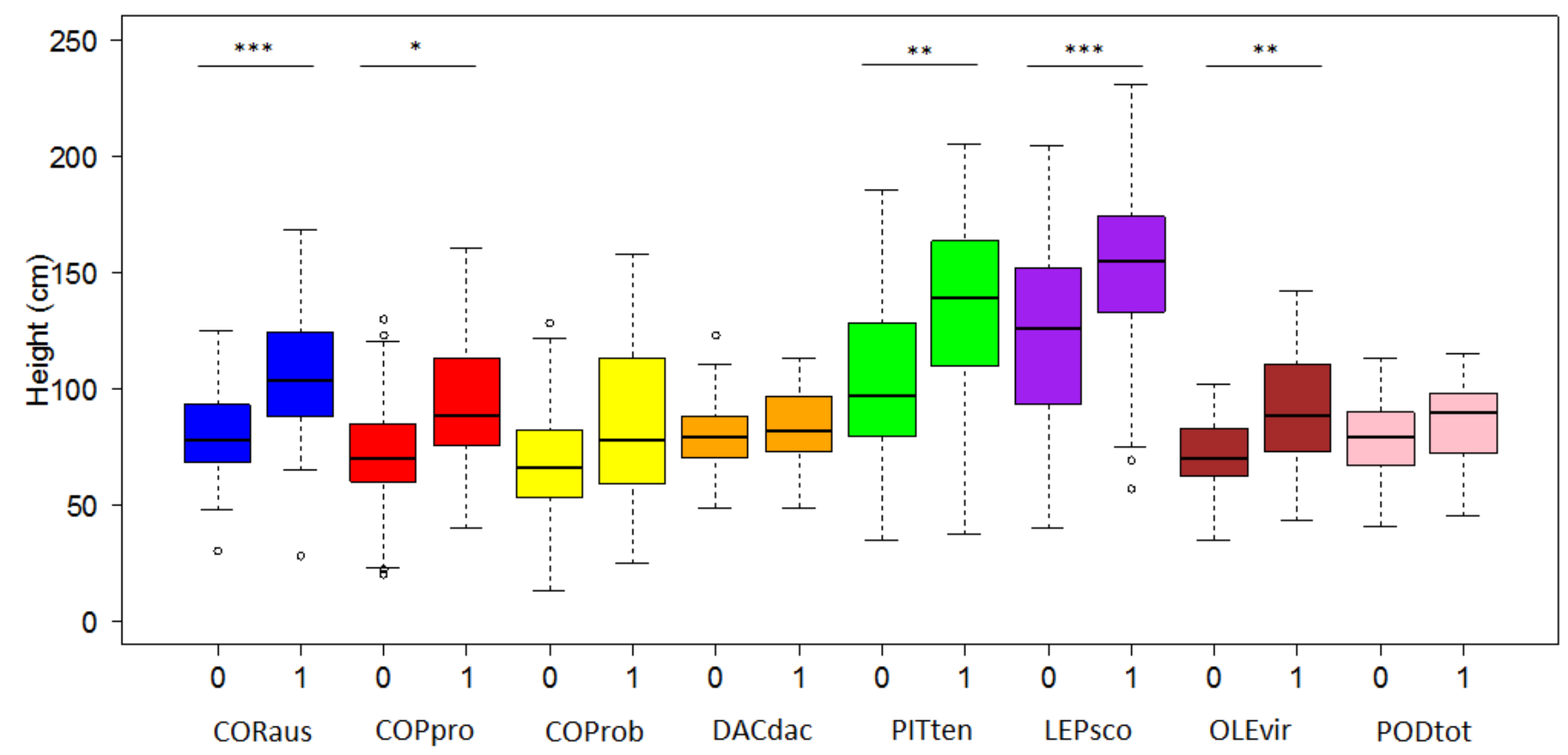

Figure 38 Plant height distributions of species 30 months after planting in reponse to topsoil removal (excavated/retained). Excavated topsoil = 0 , Retained topsoil $=1$. Focal species are represented as CORaus $=C$. australis, DACdac $=D$. dacrydioides, OLEvir $=O$. virgata, and PODtot $=P$. totara. Nurse species are represented as COPpro $=C$. propinqua, COProb $=C$. robusta, PITten $=P$. tenuifolium, and LEPsco $=$ L. scoparium. Significant main effects are represented with asterisks ( $*$ indicates a significant $p$-value: $*<0.05, * *<0.01, * * *<0.001)$. 

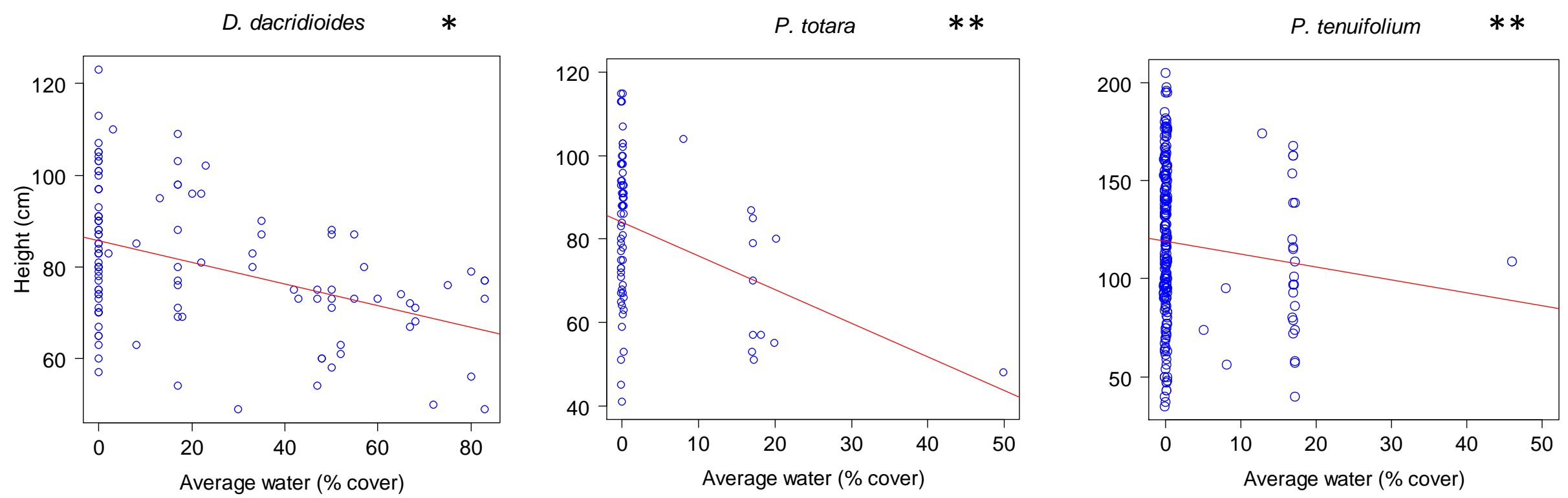

Figure 39 Scatterplots showing plant heights at different water levels (average \% cover) at the site for the species D. dacridioides, P. totara, and $P$. tenuifolium after 30-months of monitoring. The line of best fit is shown in red. Significant main effects are represented with asterisks (* indicates a significant $\mathrm{p}$-value: $*<0.05, * *<0.01, * * *<0.001)$. 


\subsection{Discussion}

\subsubsection{Plant dynamics}

The aim of this study was to evaluate the success of various management treatments in promoting the establishments of native wetland plants. Survival of plant species at Wairio Wetland over the 30 month experimental period after planting was relatively low with average focal tree survival at $54 \%$ and average nurse tree survival at $39 \%$ in comparison to other years where $50 \%$ to $75 \%$ survival has been recorded at the site (Johnson 2012). However, survival rates as low as $50 \%$ are rather common in restoration plantings, linked to poor soil conditions, high levels of plant competition, high levels of herbivory and water stress experienced in degraded sites (Keeton 2008; Sweeney et al. 2002). Survival rates of trees planted at Wairio also varied greatly between the different species. Dacrycarpus dacrydioides had the greatest survival of all focal species at $71 \%$, whereas $P$. totara had the lowest survival at $44 \%$ (Figure 20). Leptospermum scoparium had the greatest survival of all nurse species at 56\%, whereas $C$. robusta had the lowest survival at $26 \%$ (Figure 20). The nurse species $L$. scoparium and $P$. tenuifolium had the fastest growth of all species at the site and achieved the greatest average heights after 30 months, suggesting they are viable species to plant in restoration of Wairio to achieve native tree cover quickly. Plant survival also varied between blocks at the site, with the greatest survival found in blocks seven and three which remained dry year round, and lowest survival found in blocks five and six which experienced frequent waterlogging.

Plant mortality at the site was greatest in the first year after planting with focal tree mortality at $25 \%$ and nurse tree mortality at $35 \%$ (Tables $17 \& 18$ ). The first year after planting has been known as the most crucial time period to determine plant survivability, with deaths linked to environmental stresses, physical damage from incorrect planting, or plant competition (Miller \& Miller 1991). A study by Castro et al. (2002) in reforestation of a site in the Sierra Nevada Mountains, Spain found the highest mortality was in the first year after planting linked to pressures from plant competition and drought. I found that waterlogging was the primary cause of mortality for all species at the site except $D$. dacridioides. In contrast competition with weeds was the primary cause of death for $D$. 
dacriodioides. Herbivory of plants and accidental herbicide application contributed to deaths of cabbage trees in particular. Exposure to environmental conditions such as the wind pushing over trees and dry soil conditions also contributed to some deaths. It is important to acknowledge that multiple factors may interact to stress a plant and cause eventual death and that some causes of death were easier to ascertain than others. Plant deaths attributed to herbivory and herbicide application was easy to note with clear visual cues such as the plant being eaten or wilting respectively, whereas deaths attributed to competition with weeds and waterlogging involved more guess work.

\subsubsection{Effects of management treatments}

The Management treatment combination promoting the greatest survival of focal trees at the site was the excavation of topsoil, and planting of nurse trees at $1.5 \mathrm{~m}$ spacing with $63 \%$ survival, whereas the greatest survival of nurse trees was with a combination of topsoil excavation, $1.5 \mathrm{~m}$ spacing and weedmats, with $50 \%$ survival. However, the effectiveness of different management treatments varied greatly between species, and had different effects on plant survival and growth. It is also important to factor in the costs of different treatments when discussing the most successful management technique. Results from the cost-benefit analysis found that the most cost-effective option was undertaking little or no intervention in this case planting into intact topsoil, with no nurse trees or weedmats, and $1.5 \mathrm{~m}$ spacing at $\$ 8.82$ per surviving tree, and that the least cost-effective option was using all management techniques, with the excavation of topsoil, planting of nurse trees, weedmats and $1.5 \mathrm{~m}$ spacing at $\$ 26.43$ per surviving tree.

Topsoil excavation influenced the survival and growth of all species planted at Wairio with the exception of $P$. totara. Topsoil excavation can promote the removal of established weeds above-ground and below-ground in the seed bank reducing competition with native plantings (Buisson et al. 2006, Patzelt et al. 2001). I expected that all species planted in the community would respond positively to topsoil excavation with studies by Buisson et al. (2006) in Californian coastal prairies and Rasran et al. (2007) in fen grasslands in Germany noting increases in survival and establishment of target species with topsoil removal. Unexpectedly, results show that topsoil excavation promoted greater survival of $D$. 
dacridioides and C. robusta but reduced the growth of C. australis, O. virgata, C. propinqua, P.tenuifolium and L. scoparium. I propose that these species in particular may be more susceptible to the effects of waterlogging. Topsoil removal can promote waterlogging from lowering of the ground-level, which can be detrimental to species not accustomed to long durations of water inundation (Booth \& Loheide 2010, Hausman et al. 2007, Hölzel and Otte 2003, Patzelt et al. 2001). Species without specific adaptations to flooding can have a reduction in growth and development, and possible death (Jackson \& Colmer 2005). Waterlogging induced by topsoil removal at the site most likely promoted stressful conditions for $O$. virgata, $C$. australis, $C$. propinqua, $P$. tenuifolium and L. scoparium where growth was suspended to solely survive water inundation. Cordyline australis, O. virgata, C. propinqua and $P$. tenuifolium are hardy species found in wet areas that can withstand periodic flooding (NZPCN 2013), but long-term inundation may have proven too stressful. Leptospermum scoparium can survive long-term water inundation of depths up to $15 \mathrm{~cm}$ but at costs to growth and development (Cook et al. 1980). I can also speculate that changes in soil quality, specifically reductions in soil nutrients, from topsoil removal could also account for reductions in growth of these species. For example Rasran et al. (2007) in riparian fen grasslands, Northern Germany found soil fertility was significantly reduced from topsoil excavation removing nutrients in the upper soil layers. In contrast both $D$. dacridioides and C. robusta are accustomed to tolerate seasonal flooding or wet soil conditions and most likely benefitted from lower ground levels, and the removal of weeds that occurs along with topsoil removal.

I initially hypothesized that weedmats would increase survival of planted species by allowing them to establish in the absence of invasive competitors (Harrington \& Bedford 2004, Ogle 1996). Results showed that weedmats significantly influenced the growth and survival of three species at the site. Weedmats led to greater survival of $O$. virgata, greater growth of $L$. scoparium, and reduced growth of $D$. dacridioides. Greater survival of $O$. virgata could be linked to reductions in weed densities at the site, with a study by Grose (2012) at a bush restoration site in Perth, Australia finding native seedling survival was $70 \%$ greater with the use of weedmats reducing weed densities to $<1 \%$. In contrast survival of 0 . virgata was reduced when weedmats were combined with either intact topsoil, the presence of nurse 
trees or increasing percentage of water. Leptospermum scoparium most likely benefitted from the use of weedmats suppressing localised weeds around the trees and promoting growth, with support from studies by Sweeney et al. (2002) in Maryland, USA and Smail et al. (2011) in Motueka, New Zealand finding weedmats increased growth of planted seedlings in riparian areas. A particular study by Grose (2012) in Perth Australia found native seedling height was $0.5 \mathrm{~m}$ taller after five years with the use of weedmats. Suppression of weed growth and subsequent exposure to wind, sun and herbivory may have led to the reductions in growth of the fragile $D$. dacridioides associated with the presence of weedmats. Stange \& Shea (1998) in a restoration project in Minnesota, USA found weedmats reduced the growth of seedlings planted with reductions in weeds making them more visible to herbivores. It should be remembered that those trees planted without weedmats were spot-sprayed with herbicide at the time of planting, and that spot-spraying of all plants continued six monthly for the duration of the experiment, therefore all plants had some form of weed control. Marcar et al. (2000) also found that weedmat use in wet sites further promotes waterlogging of the soil from saturated weedmats. In this case the benefits of weedmats reducing weed densities could be outweighed by the increased waterlogging effect. This leads us to believe that some form of weed control is required in restoration plantings. For some species a weedmat does seem better than initial spot spraying however this effect would be expected to be strongest in the first six to twelve months, as after that point the weedmat would have degraded and grasses come through it anyway.

The concurrent planting of nurse trees had a significant effect on focal species survival and growth. Cordyline australis was more likely to have higher survival and greater growth, $D$. dacridioides was more likely to have higher survival and $P$. totara was more likely to have greater growth with the presence of nurse trees. In contrast $O$. virgata was more likely to have reduced survival with a combination of nurse tree planting and weedmat presence. The findings for $C$. australis, $D$. dacridioides and $P$. totara support my initial hypotheses and other studies by Castro et al. (2002) and Gómez -Aparicio et al. (2005) both in forests in the Sierra Nevada Mountains, Spain where nurse trees promoted the survival of native plantings by $25 \%$ and $50 \%$ respectively. Some losses of $C$. australis at the site were attributed to 
herbivory and accidental herbicide spraying with twelve and eight individuals dying respectively from these causes. Nurse trees potentially offered protection from herbivory and shelter from accidental herbicide spraying for $C$. australis at the site, in turn increasing its survival. Nurse trees have been known to shade out and suppress grasses and weeds (Hardwick et al. 1997), provide shelter from adverse environmental conditions (Cavieres et al. 2006) and aid protection from herbivory (Calloway \& Pugnaire 1999) at various sites aiding establishment of native plantings. Dacrycarpus dacridioides is a small and slender fragile tree (Cockayne 1923) that is susceptible to damage from strong winds, competition with weeds and herbivore grazing and most likely benefited from nurse tree plantings at the site offering protection from these factors. Results showed greater growth of $P$. totara in the presence of nurse trees which is unexpected as the sunlight-demanding species usually stops growing when in shady conditions and with the presence of strong plant competition (Bergin 2000). There is a possibility that the nurse trees planted at the site are too small in size at the moment to compete with native tree plantings for sunlight and below-ground nutrients but could still provide shelter from strong winds at the site proving beneficial to growth. The reduction in survival of $O$. virgata with the combination of nurse trees and presence of weedmats is peculiar. The use of weedmats alone increased survival of $O$. virgata suggesting nurse trees are detrimental to its survival. Olearia virgata is a fast growing tree species (Cockayne 1923), that can rapidly develop direct below-ground and above ground competition for sunlight and resources with the fast-growing nurse species at the site, proving detrimental to its survival. In the future, nurse species could become a significant competitor with focal species for above- and below- ground nutrients, with the potential for a reduction in revegetation success.

The spacing of plants at $1.5 \mathrm{~m}$ apart had a significant positive effect on the majority of nurse species at the site with the exception of $C$. robusta. There is considerable debate over the correct distance for seedlings to be planted in revegetation. It is proposed that planting trees spaced further apart results in greater growth and survival of plantings in the longterm from reductions in density dependent mortality and plant competition (Padilla \& Pugnaire 2006; Vesk \& Mac Nally 2006). However, in the short-term, plants spaced closer together can facilitate each other by the "nurse effect" (O'Brien \& Zedler 2006). Results 
showed that the survival of $C$. propinqua and $P$. tenuifolium and both the survival and growth of L. scoparium was greater when nurse species were planted further apart at $1.5 \mathrm{~m}$ spacing compared to $0.75 \mathrm{~m}$ spacing. These results contrast a study by NeSmith (1993) on flowering trees in Georgia where plant growth after one year was greater when planted closer together and a study by Willebrand et al. (1993) in Sweden where spacing of Willow trees had no effect on plant growth. Stoll \& Bergius (2005) suggest survival and growth of plants is strongly linked to the distance to the closest neighbour and overall planting density. Leptospermum scoparium and $P$. tenuifolium are fast growing species that reached the greatest heights sooner than other species planted at Wairio. Interspecific competition between these larger species for sunlight and below-ground resources would be strong when spaced closer together due to their high resource requirements. Coprosma propinqua was a slow-growing species at the site but also benefited from greater spacing, suggesting small trees are also at risk from interspecific competition when spaced closer together.

The majority of wetland plant species have physical adaptations or physiological responses to survive in waterlogged or flooded areas. However, under long term conditions of complete plant submergence only a few aquatic species have been known to survive (Visser et al. 2003). The duration of flooding and depth of water levels are major factors determining plant survival and growth (Casanova \& Brock 2003). Water levels had a significant detrimental effect on the survival of all species planted at Wairio with the exception of $D$. dacridioides. Results showed increasing water levels resulted in reductions in survival of $P$. totara, O. virgata, C. robusta, P. tenuifolium, L. scoparium and C. propinqua, and reductions in the growth of $D$. dacridioides, $P$. totara, and $C$. propinqua. All species planted at the site are commonly found in wet areas with various adaptations to survive waterlogging. However, long-term flooding can lead to oxygen and carbon dioxide depletion in the water and soil influencing crucial cellular processes such as aerobic respiration, metabolism and photosynthesis in plants (Jackson 2006). Waterlogging was particularly detrimental to the growth of $C$. australis and L. scoparium, even though they are frequently found in wetland sites throughout New Zealand (Smale et al. 2001, NZPCN 2013). In some plots at the site the long periods of water inundation and total submergence may have proven too stressful for these plant species, with reductions in growth or possible death. A 
study by Casanova \& Brock (2003) in New South Wales, Australia found that growth of terrestrial wetland plant species was reduced during longer and deeper floods. Blocks four, five and six at the site, in particular, experienced long periods of flooding and high water levels whereby high mortality (>90\%) was commonplace. Dacrycarpus dacridioides is a common swamp plant that thrives in wet, damp conditions (Cockayne 1923) and was the sole survivor in many of these waterlogged plots. In contrast the reduced growth rates of $D$. dacridioides in areas with increasing water levels could be linked to its remaining energy sources being put into survival mode with growth being sacrificed.

In conclusion, this experiment found that native saplings planted at the site experienced the greatest mortality in the first year, with plant deaths that appeared to be most commonly attributed to waterlogging of the site and competition with grasses and weeds. Topsoil excavation, planting of nurse trees at $1.5 \mathrm{~m}$ spacing and the use of herbicide or weedmats was the most effective management treatment combination to ensure plant survival at Wairio Wetland. However, the success of management treatments varied greatly between species at the site and had different impacts on plant growth. The Management treatments used in this study have the potential to facilitate the establishment of future plantings at Wairio and could be used in other wetland restoration efforts in New Zealand. 


\subsection{References}

Ashby WC 1997. Soil Ripping and Herbicides Enhance Tree and Shrub Restoration on Strip mines. Restoration Ecology 5(2): 169-177.

Bates D, Maechler M, Bolker B, Walker S 2013. Ime4: Linear mixed-effects models using Eigen and S4 classes. http://cran.r-project.org/web/packages/Ime4/Ime4.pdfR. R package version 1.0-6.

Bergin DO 2000. Current knowledge relevant to management of Podocarpus totara for timber. New Zealand Journal of Botany 38(3): 343-359.

Beever R, Forster RLS, Rees-George J, Robertson GI, Wood GA, Winks CJ 1996. Sudden decline of cabbage tree. NZ Journal of Ecology, 20(1): 53-68

Blignaut A, Milton SJ 2005. Effects of multispecies clumping on survival of three succulent plant species translocated onto mine spoil in the succulent Karoo Desert, South Africa. Restoration Ecology 13: 15-19.

Bodmin K 2010. Weeds. In: Peters M, Clarkson B eds. Wetland Restoration: A Handbook for New Zealand Freshwater Systems. Lincoln, Manaaki Whenua Press. 273 p.

Booth EG, Loheide SP 2010. Effects of evapotranspiration partitioning, plant water stress response and topsoil removal on the soil moisture regime of a floodplain wetland: implications for restoration. Hydrological Processes 24: 2934-2946.

Budelsky RA, Galatowitsch SM 2000. Effects of water regime and competition on the establishment of a native sedge in restored wetlands. Journal of Applied Ecology 37(6): 971-985. 
Buisson E, Holl KD, Anderson S, Corcket E, Hayes GF, Torre F, Peteers A, Dutoit T 2006. Effect of Seed Source, Topsoil Removal, and Plant Neighbor Removal on Restoring California Coastal Prairies. Restoration Ecology 14(4): 569-577.

Callaway RM, Pugnaire FL 1999. Facilitation in plant communities. In: FL Pugnaire, F Valladares eds. Handbook of functional plant ecology. New York, Marcel Dekker. Pp 623-648.

Castro J, Zamora R, Hódar JA, Gómez JM 2002. Use of Shrubs as Nurse Plants: A New Technique for Reforestation in Mediterranean Mountains. Restoration Ecology 10(2): 297-305.

Cavieres LA, Badano EI, Sierra-Almeida A, Gómez-González S, Molina-Montenegro MA 2006. Positive interactions between alpine plant species and the nurse cushion plant Laretia acaulis do not increase with elevation in the Andes of central Chile. New Phytologist 169: 59-69.

Clarkson B \& Peters M 2010. Revegetation. In: Peters M, Clarkson B eds. Wetland Restoration: A Handbook for New Zealand Freshwater Systems. Manaaki Whenua Press, Lincoln, New Zealand. 273 p.

Cockayne L 1923. The Cultivation of New Zealand Plants. Auckland, Whitcombe and Tombs Ltd. 139 p.

Cook JM, Mark AF, Shore BF 1980. Responses of Leptospermum scoparium and L. ericoides (Myrtaceae) to waterlogging. New Zealand Journal of Botany 18(2): 233-246.

D'Antonio C, Meyerson LA 2002. Exotic Plant Species as Problems and Solutions in Ecological Restoration: A Synthesis. Restoration Ecology 10(4): 703-713. 
Dawson J, Lucas R 2000. Nature Guide to the New Zealand Forest. New Zealand, Godwit. $312 \mathrm{p}$.

Dulohery CJ, Kolka RK, McKevlin MR 2000. Effects of a willow overstory on planted seedlings in a bottomland restoration. Ecological Engineering 16: S57-S66.

Enright NJ, Ogden J 1995. The Southern conifers - a synthesis. In : Enright NJ, Hill S eds. Ecology of the southern conifers. Melbourne, Melbourne University Press. Pp. 271287.

Enright P, Olaf J, Silbery Y 2008. Vascular plants Wairio Wetlands, Lake Wairarapa, Wairio Wetland, Lake Wairarapa.

Gardiner T \& Vaughan A 2008. Responses of ground flora and insect assemblages to tree felling and soil scraping as an initial step to heathland restoration at Norton Heath Common, Essex, England. Conservation Evidence 5: 95-100.

Gardner R 2002. Notes towards an excursion Flora: manuka (Leptospermum scoparium) Myrtaceae. Auckland Botanical Society Journal 57: 147-149.

Geissen V, Wang S, Oostindie K, Huerta E, Zwart KB, Smit A, Ritsema CJ, Moore D 2013. Effects of topsoil removal as a nature management technique on soil functions. Catena 101: 50-55.

Gómez-Aparicio L, Gómez JM, Zamora R, Boettinger JL 2005. Canopy vs. soil effects of shrubs facilitating tree seedlings in Mediterranean montane ecosystems. Journal of Vegetation Science 16(2): 191-198.

Grove E, Paris B, Clarkson BD 2006. Waiwhakareke Restoration Plantings: Establishment of Monitoring Plots 2005-06. Centre for Biodiversity and Ecology Research Report No. 44. Hamilton, University of Waikato. 14 p. 
Hausman CE, Fraser LH, Kershner MW, de Szalay FA 2007. Plant community establishment in a restored wetland: Effects of soil removal. Applied Vegetation Science 10: 383-390.

Hardwick K, Healey J, Elliott S, Garwood N, Anusarnsunthorn V 1997. Understanding and assisting natural regeneration processes in degraded seasonal evergreen forests in northern Thailand. Forestry Ecology and Management 99: 203-214.

Harrington KC, Bedford TA 2004. Control of weeds by paper mulch in vegetable and trees. New Zealand Plant Protection 57: 37-40.

Hölzel N, Otte A 2003. Restoration of a species-rich flood meadow by topsoil removal and diaspore transfer with plant material. Applied Vegetation Science 6: 131-140.

Huddleston RT, Young TP 2004. Spacing and Competition Between Planted Grass Plugs and Preexisting Perennial Grasses in a Restoration Site in Oregon. Restoration Ecology 12 (4): 546-551.

Innes KPC, Kelly D 1992. Water potentials in native woody vegetation during and after a drought in Canterbury. New Zealand Journal of Botany 30(1): 81-94.

Izzaurralde RC, Solberg ED, Nyborg M, Malhi SS 1998. Immediate effects of topsoil removal on crop productivity loss and its restoration with commercial fertilizers. Soil and Tillage Research 46(3-4): 251-259.

Jackson MB, Colmer TD 2005. Response and Adaptation by Plants to Flooding Stress. Annals of Botany 96(4): 501-505.

Johnson BA 2012. Ecological restoration of the Wairio Wetland, Lake Wairarapa: Water table relationships and cost-benefit analysis of restoration strategies. Wellington, Victoria University of Wellington. 124 p. 
Josselyn M, Chamberlain S, Goodnight K, Hopkins H, Fiorillo A 1993. Evaluation of coastal conservancy enhancement projects, 1978-1992. California, San Francisco State University.

Keeton WS 2008. Evaluation of Tree Seedling Mortality and Protective Strategies in Riparian Forest Restoration. Northern Journal of Applied Forestry 25(3): 117-123.

Klimkowska A, Dzierz P, Brzezin'ska K, Kotowski W, Medrzycki P 2010a. Can we balance the high costs of nature restoration with the method of topsoil removal? Case study from Poland. Journal for Nature Conservation 18(3): 202-205.

Klimkowska A, Kotowski W, van Diggelen R, Grootjans AP, Dzierża P, Brzezińska K 2010b. Vegetation Re-development After Fen Meadow Restoration by Topsoil Removal and Hay Transfer. Restoration Ecology 18(6): 924-933.

Kneitel JM, Lessin CL 2010. Ecosystem-phase interactions: aquatic eutrophication decreases terrestrial plant diversity in California vernal pools. Oecologia 163: 461-469.

Lai PCC, Wong BSF 2005. Effects of tree guards and weed mats on the establishment of native tree seedlings: implications for forest restoration in Hong Kong, China. Restoration Ecology 13(1): 138-143.

Laarmann D, Korjus H, Sims A, Stanturf JA, Kivistea A, Köster K 2009. Analysis of forest naturalness and tree mortality patterns in Estonia. Forest Ecology Management 258: S187-S195.

Lenssen JPM, Menting FBJ, van der Putten WH, Blom CWPM 1999. Effects of sediment type and water level on biomass production of wetland plant species. Aquatic Botany 64(2): 151-165. 
Marcar NE, Hossain AKMA, Crawford DF, Nicholson AT 2000. Evaluation of tree establishment treatments on saline seeps near Wellington and Young in New South Wales. Australian Journal of Experimental Agriculture 40: 99-106.

Mark AF, Johnson PN, Wilson JB 1977. Factors involved in the recent mortality of plants from forest and scrub along the Lake Te Anau shoreline, Fiordland. Proceedings of the New Zealand Ecological Society 24: 34-42.

McLeod KW, Reed MR, Nelson EA 2001. Influence of a willow canopy on tree seedling establishment for wetland restoration. Wetlands 21: 395-402.

Meli P, Martínez-Ramos M, Rey-Benayas JM 2013. Selecting Species for Passive and Active Riparian Restoration in Southern Mexico. Restoration Ecology 21: 163-165.

Metcalfe LJ 1993. The cultivation of New Zealand plants. Auckland, Godwit Press Limited. $260 \mathrm{p}$.

Miller RH, Miller RW 1991. Planting survival of selected street tree taxa. Journal of Arboriculture 17(7): 185-191.

NeSmith DS 1993. Plant Spacing Influences Watermelon Yield and Yield Components. Horticultural Science 28(9): 885-887.

O' Brien EL, Zedler JB 2006. Accelerating the restoration of vegetation in a southern California salt marsh. Wetlands Ecology and Management 14: 269-286.

Ogle M 1996. Factors affecting the early growth and survival of indigenous seedlings planted for the purpose of ecological restoration. Christchurch, University of Canterbury. 108 p. 
Padilla FM, Pugnaire FI 2006. The role of nurse plants in the restoration of degraded environments. Frontiers in Ecology and the Environment 4(4): 196-202.

Paling El, van Keulen M, Wheeler KD, Phillips J, Dyhrberg R 2003. Influence of Spacing on Mechanically Transplanted Seagrass Survival in a High Wave Energy Regime. Restoration Ecology 11(1): 56-61.

Patzelt A, Wild U, Pfadenhauer J 2001. Restoration of Wet Fen Meadows by Topsoil Removal: Vegetation Development and Germination Biology of Fen Species. Restoration Ecology 9(2): 127-136.

Pinheiro J, Bates D, DebRoy S, Sarkar D 2013. nlme: Linear and Nonlinear Mixed Effects Models. http://cran.r-project.org/web/packages/nlme/nlme.pdf. R package version 3.1-113.

Poole AL, Adams NM 1994. Trees and Shrubs of New Zealand. Lincoln, Manaaki Whenua Press. 256 p.

Porteous T 1993. Native Forest Restoration: A Practical Guide for Landowners. Wellington, QEII National Trust. 184p.

Prévosto B, Balandier P 2007. Influence of nurse birch and Scots pine seedlings on early aerial development of European beech seedlings in an open-field plantation of Central France. Forestry 80(3): 253-264.

Ramseier D 2000. Why remove the topsoil for fen restoration? - Influence of water table, nutrients and competitors on the establishment of four selected plant species. Bulletin of the Geobotanical Institute ETH 66: 25-35. 
Rasran L, Vogt K, Jensen K 2007. Effects of topsoil removal, seed transfer with plant material and moderate grazing on restoration of riparian fen grasslands. Applied Vegetation Science 10: 451-460.

Schirmer J, Field J 2000. The Cost of Revegetation. Final Report to Environment Australia. Canberra, ANU Forestry \& Greening Australia. 101 p.

Smail SJ, Ledgard N, Langer ER, Henley D 2011. Establishing native plants in a weedy riparian environment. New Zealand Journal of Marine and Freshwater Research 45(3): 357367.

Smale MC, Whaley PT, Smale PN 2001. Ecological Restoration of Native Forest at Aratiatia, North Island, New Zealand. Restoration Ecology 9(1): 28-37.

Stange EE, Shea KL 1998. Effects of deer browsing, fabric mats, and tree shelters on Quercus rubra seedlings. Restoration Ecology 6: 29-34.

Stinson KA, Campbell SA, Powell JR, Wolfe BE, Callaway RM, Thelen GC, Hallett SG, Prati D 2006. Invasive Plant Suppresses the Growth of Native Tree Seedlings by Disrupting Belowground Mutualisms. PLoS Biology 4(5): e140.

Stoll P, Bergius E 2005. Pattern and process: competition causes regular spacing of individuals within plant populations. Journal of Ecology 93(2): 395-403.

Sweeney BW, Czapka SJ, Yerkes T 2002. Riparian Forest Restoration: Increasing Success by Reducing Plant Competition and Herbivory. Restoration Ecology 10(2): 392-400.

Vesk PA, Mac Nally R 2006. The clock is ticking-Revegetation and habitat for birds and arboreal mammals in rural landscapes of southern Australia. Agriculture, Ecosystems and Environment 112: 356-366. 
Visser EJW, Voesenek LACJ, Vartapetian BB, Jackson MB 2003. Flooding and Plant Growth. Annals of Botany 91(2): 107-109.

Wairiu M, Lal R 2003. Soil organic carbon in relation to cultivation and topsoil removal on sloping lands of Kolombangara, Solomon Islands. Soil \& Tillage Research 70: 19-27.

Willebrand E, Ledin S, Verwijst T 1993. Willow coppice systems in short rotation forestry: Effects of plant spacing, rotation length and clonal composition on biomass production. Biomass and Bioenergy 4(5): 323-331.

Woodward CL 1996. Soil compaction and topsoil removal effects on soil properties and seedling growth in Amazonian Ecuador. Forest Ecology and Management 82:197-209. 


\section{Appendix 3.6}

Appendix 3.6.1

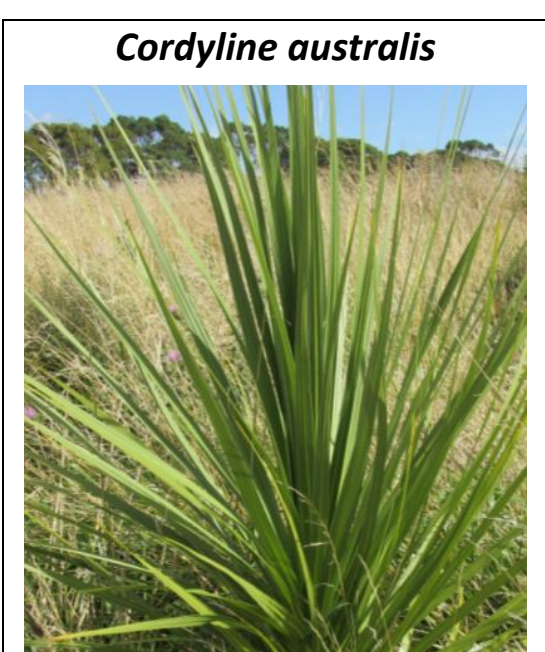

Coprosma propinqua

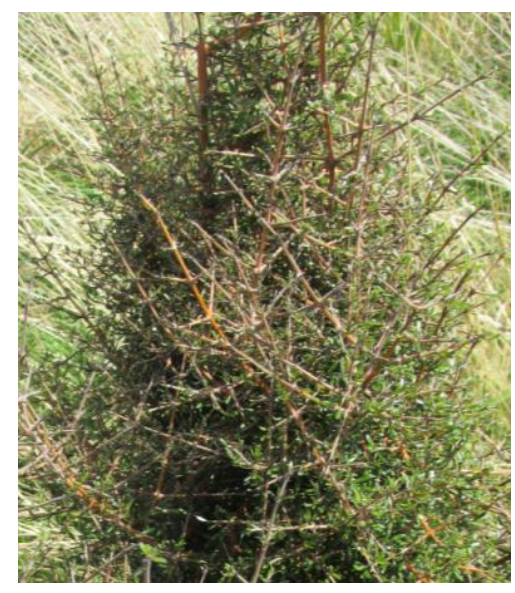

Dacrycarpus dacridioides

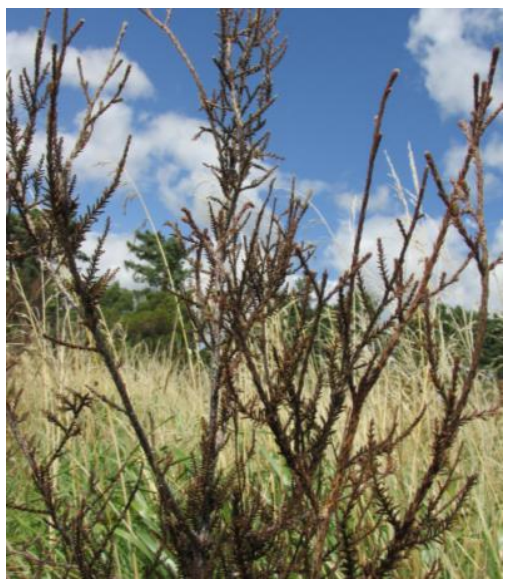

Coprosma robusta

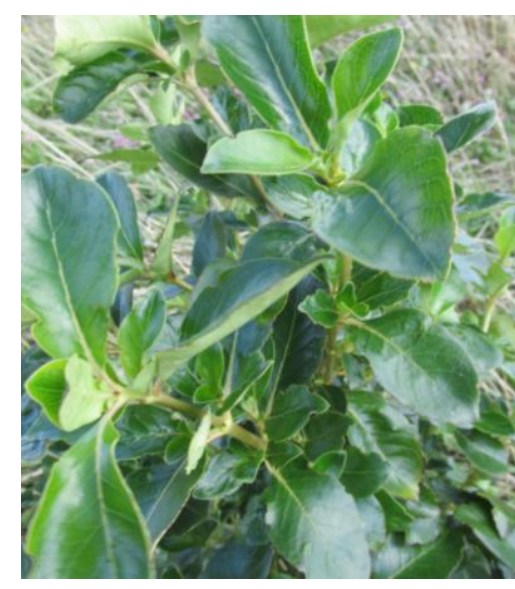

Podocarpus totara

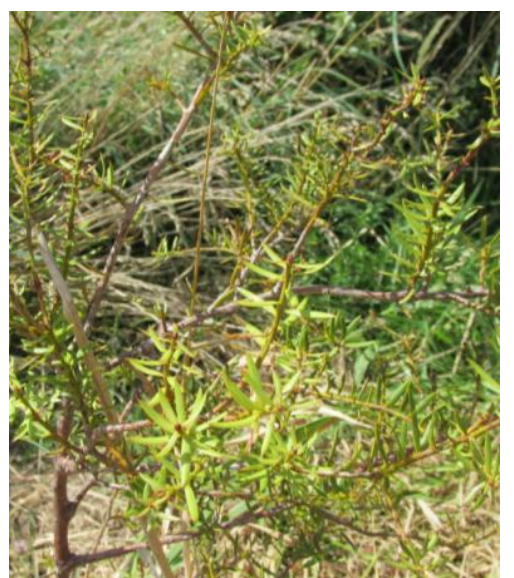

Leptospermum scoparium

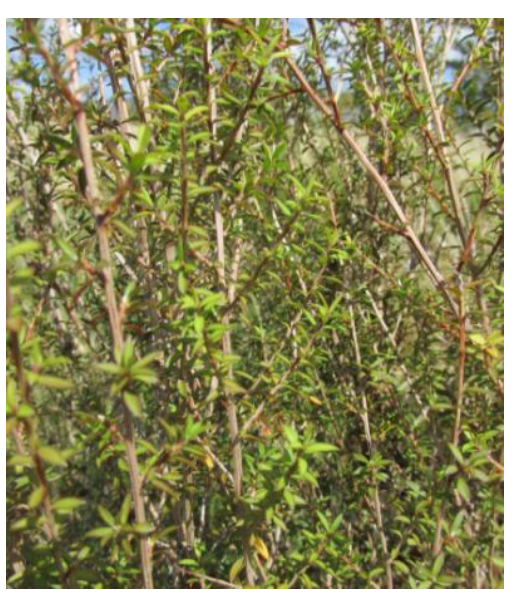

Olearia virgata

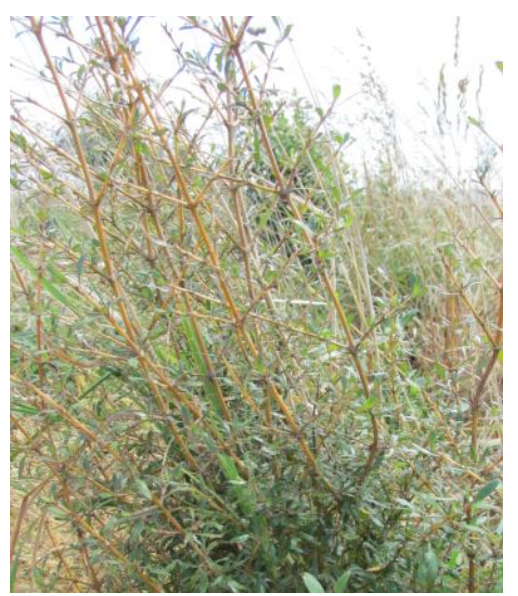

Pittosporum tenuifolium

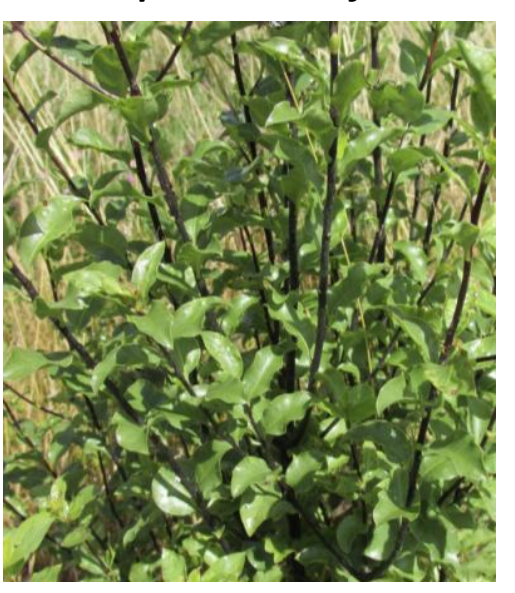

Figure 40 Study species planted at Wairio wetland. Top row: Focal species, bottom row: nurse species. Photos taken by author. 


\section{Appendix 3.6.2}

Table 27 Plot treatments and nurse species combinations in blocks at the site.

\begin{tabular}{|c|c|c|c|c|c|}
\hline Block \# & Topsoil & Plot treatment 1 & Plot treatment 2 & Plot treatment 3 & Nurse species combination \\
\hline $1 a$ & Scraped & No nurse natives & Concurrent planting & na & C. robusta and C. propinqua \\
\hline $1 b$ & Not scraped & No nurse natives & Concurrent planting & na & C. robusta and C. propinqua \\
\hline $2 a$ & Scraped & No nurse natives & Concurrent planting & na & P. tenuifolium and L. scoparium \\
\hline $2 b$ & Not scraped & No nurse natives & Concurrent planting & na & P. tenuifolium and L. scoparium \\
\hline $3 a$ & Scraped & No nurse natives & Concurrent planting & Advance planting $1.5 \mathrm{~m}$ spacing & P. tenuifolium and L. scoparium \\
\hline $3 b$ & Not scraped & No nurse natives & Concurrent planting & Advance planting $1.5 \mathrm{~m}$ spacing & P. tenuifolium and L. scoparium \\
\hline $4 a$ & Scraped & No nurse natives & Concurrent planting & Advance planting $0.75 \mathrm{~m}$ spacing & C. robusta and C. propinqua \\
\hline $4 b$ & Not scraped & No nurse natives & Concurrent planting & Advance planting $0.75 \mathrm{~m}$ spacing & C. robusta and C. propinqua \\
\hline $5 a$ & Scraped & No nurse natives & Concurrent planting & Advance planting $1.5 \mathrm{~m}$ spacing & C. robusta and C. propinqua \\
\hline $5 b$ & Not scraped & No nurse natives & Concurrent planting & Advance planting $1.5 \mathrm{~m}$ spacing & C. robusta and C. propinqua \\
\hline $6 b$ & Not scraped & No nurse natives & Concurrent planting & Advance planting $0.75 \mathrm{~m}$ spacing & P. tenuifolium and L. scoparium \\
\hline $7 a$ & Not scraped & No nurse natives & Concurrent planting & Advance planting $1.5 \mathrm{~m}$ spacing & P. tenuifolium and L. scoparium \\
\hline $7 b$ & Scraped & No nurse natives & Concurrent planting & Advance planting $0.75 \mathrm{~m}$ spacing & P. tenuifolium and L. scoparium \\
\hline $8 a$ & Not scraped & No nurse natives & Concurrent planting & Advance planting $1.5 \mathrm{~m}$ spacing & C. robusta and C. propinqua \\
\hline $8 b$ & Scraped & No nurse natives & Concurrent planting & Advance planting $0.75 \mathrm{~m}$ spacing & C. robusta and C. propinqua \\
\hline $9 a$ & Scraped & No nurse natives & Concurrent planting & Advance planting $1.5 \mathrm{~m}$ spacing & C. robusta and C. propinqua \\
\hline $9 b$ & Not scraped & No nurse natives & Concurrent planting & Advance planting $1.5 \mathrm{~m}$ spacing & C. robusta and C. propinqua \\
\hline $10 a$ & Scraped & No nurse natives & Concurrent planting & Advance planting $0.75 \mathrm{~m}$ spacing & P. tenuifolium and L. scoparium \\
\hline $10 \mathrm{~b}$ & Not scraped & No nurse natives & Concurrent planting & Advance planting $0.75 \mathrm{~m}$ spacing & P. tenuifolium and L. scoparium \\
\hline
\end{tabular}




\section{Appendix 3.6.3}

Table 28 Focal and nurse species survival (proportion alive) within blocks at the site, 30 months after planting.

\begin{tabular}{|c|c|c|c|c|c|c|c|c|c|}
\hline \multirow[t]{2}{*}{ Block \# } & \multicolumn{4}{|c|}{ Focal species } & \multicolumn{4}{|c|}{ Nurse species } & \multirow[t]{2}{*}{ Average } \\
\hline & C. australis & D. dacridioides & P. totara & O. virgata & C. robusta & C. propinqua & P. tenuifolium & L. scoparium & \\
\hline 1 & 0.56 & 0.75 & 0.75 & 0.69 & 0.44 & 0.42 & NA & NA & 0.53 \\
\hline 2 & 0.50 & 0.94 & 0.56 & 0.63 & NA & NA & 0.73 & 0.48 & 0.63 \\
\hline 3 & 0.88 & 0.69 & 0.63 & 0.56 & NA & NA & 0.70 & 0.76 & 0.72 \\
\hline 4 & 0.19 & 0.50 & 0.06 & 0.19 & 0.12 & 0.14 & NA & NA & 0.16 \\
\hline 5 & 0.06 & 0.38 & 0.00 & 0.06 & 0.02 & 0.03 & NA & NA & 0.05 \\
\hline 6 & 0.25 & 0.88 & 0.00 & 0.06 & NA & NA & 0.01 & 0.15 & 0.13 \\
\hline 7 & 0.63 & 0.88 & 0.56 & 0.94 & NA & NA & 0.77 & 0.75 & 0.76 \\
\hline 8 & 0.81 & 0.75 & 0.76 & 0.81 & 0.54 & 0.45 & NA & NA & 0.57 \\
\hline 9 & 0.81 & 0.88 & 0.38 & 0.44 & 0.48 & 0.35 & NA & NA & 0.47 \\
\hline 10 & 0.31 & 0.44 & 0.69 & 0.63 & NA & NA & 0.61 & 0.61 & 0.59 \\
\hline
\end{tabular}




\section{Appendix 3.6.4}

Table 29 Cost (per tree) of various management treatment options. Labour costs were excluded. Release spraying costs applied to every tree planted.

\begin{tabular}{|c|c|c|c|}
\hline Treatment & & Option & \\
\hline Weedmat & $\begin{array}{c}\text { Weedmat } \\
\$ 2.17\end{array}$ & $\underline{\mathrm{OR}}$ & $\begin{array}{c}\text { No weedmat, spot-spray } \\
\$ 0.29\end{array}$ \\
\hline Topsoil & $\begin{array}{l}\text { Excavation } \\
\$ 0.79\end{array}$ & $\underline{\mathrm{OR}}$ & $\begin{array}{c}\text { Intact, release spray } \\
\$ 0.29\end{array}$ \\
\hline Nurse & $\begin{array}{l}\text { Nurse }(4 \times \text { trees) } \\
\quad \$ 8.10\end{array}$ & $\underline{\mathrm{OR}}$ & $\begin{array}{l}\text { No nurse } \\
\$ 0.00\end{array}$ \\
\hline $\begin{array}{l}\text { Release } \\
\text { spraying }\end{array}$ & & $\$ 0.90$ each & \\
\hline Focal trees & & $\$ 2.33$ each & \\
\hline Nurse trees & $\begin{array}{l}\text { L. scoparium \& } \\
\text { P. tenuifolium } \\
\$ 1.50 \text { each }\end{array}$ & $\underline{\mathrm{OR}}$ & $\begin{array}{l}\text { C. robusta \& } \\
\text { C. propinqua } \\
\$ 2.55 \text { each }\end{array}$ \\
\hline
\end{tabular}




\section{Chapter 4}

\section{CONCLUSIONS \& RECOMMENDATIONS}

The following chapter presents the main conclusions from the two studies undertaken in this thesis. The overall aim of this thesis was to help inform future restoration efforts and management practices undertaken for wetland restoration, especially with reference to Wairio Wetland, Wairarapa. The first study (Chapter two) examined the changes in community composition of a wetland plant community in response to the addition of phosphate and nitrate fertiliser, and the second study (Chapter three) investigated the role of various management treatments in facilitating the survival and growth of planted native woody vegetation.

\subsection{Summary of Key Findings}

\subsubsection{Effect of nutrient addition on a native wetland plant community.}

The plant community at Wairio Wetland showed neither a positive nor negative response to fertiliser addition after my five month experiment. These findings contrast a vast amount of studies in a wide range of environments that have reported increases in plant biomass (Gough et al. 2000, Iverson et al. 2010; Leyshon 1991) and a reduction in plant community biodiversity (Harpole \& Tilman 2007; Stevens et al. 2010) with common/introduced species outcompeting rare/native species (Ceulemans et al. 2012; Pekin et al. 2012; Tyler et al. 2007) in response to nitrogen and/or phosphorous addition. Fifteen plant species were recorded at the site over the study period with seasonal variations in the plant community commonly observed. Nitrogen addition had a significant positive effect on the native sedge I. prolifera with a $2.8 \%$ increase in plant biomass, however this effect was deemed insignificant under Holm-Bonferroni method to control the family-wise error rate. The short duration of the experiment (five months in total) may have obscured the response of the species to nutrient addition with limited time to note visual changes in above-ground plant biomass, with changes in below-ground biomass more likely to occur first (López -Bucio et al. 2003). The summer drought experienced at the site may have also prohibited species 
growth rates (McDowell et al. 2008). There is a high possibility that the accumulation of nutrients in the soil from nutrient addition in this experiment will dictate future changes in plant species composition at the site, with other studies reporting visible changes in vegetation composition after long-term exposure (Gough et al. 2000, Iverson et al. 2010, Leyshon 1991). It is recommended that this experiment is continued at Wairio Wetland in a longer-term capacity to fully assess the effects of eutrophication on wetland plants. This study, in light of the wider literature, suggests that the response of plants to the effects of eutrophication vary greatly between different species, environments, and time periods, and that restoration efforts need to be focussed on a site-specific basis.

\subsubsection{Management treatments promoting the establishment of native wetland vegetation}

Interspecific competition and hydrology were the main processes that appeared to be influencing the establishment of native plantings at Wairio Wetland. Competition between native plantings and established grasses and waterlogging were the most commonly identified causes of death at the site, with plant mortality greatest in the first year after planting. Waterlogging, in particular, had a significant negative effect on the survival of $C$. propinqua, $C$. robusta and $L$. scoparium, growth of $D$. dacridioides, and survival and growth of $P$. totara and $P$. tenuifolium. Topsoil excavation, planting of nurse trees at $1.5 \mathrm{~m}$ spacing and the use of weedmats or herbicide was the most effective management treatment combination promoting survival of plantings at Wairio. However, the success of management treatments in promoting plant establishment varied greatly between species at the site and had different impacts on plant growth. Topsoil excavation had a significant positive effect on survival of $D$. dacridioides and $C$. robusta but a significant negative effect on the growth of $C$. australis, $O$. virgata, $C$. propinqua, $P$. tenuifolium and $L$. scoparium. The contrasting impacts of topsoil excavation between species can be linked to a trade-off between the benefits from a reduction in plant competition with removal of weeds and grasses above- and below- ground (Buisson et al. 2006; Hölzel \& Otte 2003), and the drawbacks of the lower ground level promoting greater waterlogging (Booth \& Loheide 2010; Klimkowska et al. 2010) and the removal of soil nutrients from the topsoil (Hausman et al. 2007; Woodward 1996). The concurrent planting of nurse trees with focal trees had a 
significant positive effect on the survival of $D$. dacridioides, growth of $P$. totara, and survival and growth of $C$. australis, linked to the benefits of protection from herbivory, shelter from strong winds at the site and suppression of localised grasses and weeds, which has been noted in other studies that have used nurse trees (Castro et al. 2002; Gómez -Aparicio et al. 2005). The planting of nurse trees further apart at $1.5 \mathrm{~m}$ compared to $0.75 \mathrm{~m}$ had an unexpected significant positive effect on the survival of $C$. propinqua and $P$. tenuifolium, and survival and growth of L. scoparium, suggesting both above- and below-ground interspecific competition can hinder plant establishment from a young age. Weedmats had a significant positive effect on survival of $O$. virgata and growth of $L$. scoparium, most likely benefiting from a reduction in localised weeds and grasses (Harrington \& Bedford 2004, Ogle 1996), however weedmats had a significant negative effect on growth of $D$. dacridioides, which can be attributed to either water saturation promoted by weedmats or an increased exposure to wind and herbivory from the reductions in surrounding weeds (Marcar et al. 2000; Stange \& Shea 1998). This study has shown that management treatments have the potential to increase the survival and growth of native trees planted at Wairio, which could be used in future revegetation efforts at the site. The native species used in this experiment responded differently to various management treatments and site conditions, suggesting speciesspecific, site-appropriate planting is required for successful establishment of vegetation at Wairio. The management treatments used at Wairio could be used in other wetland restoration efforts undertaken in New Zealand. 


\subsection{Implications of this research for Wairio Wetland}

The findings from these experiments carried out at Wairio Wetland offer invaluable advice for future restoration efforts at the site. I recommend that the planned water diversion of potentially nutrient-rich water through Wairio Wetland proceeds with caution, while its possible effects on the wetland plant community are further assessed. The results from the nutrient experiment study were inconclusive with no clear changes in community structure, biomass or diversity attributed to the addition of phosphorous and nitrogen in Stage 2 at Wairio Wetland. There is a high possibility that the plant community will change in the near future in response to accumulation of soil nutrients and therefore should ideally be monitored further.

The planting experiment in Stage 3 of Wairio Wetland demonstrated that the main factors influencing the establishment of native wetland plants at the site are competition with weeds and waterlogging of the site. Plant mortality was commonly attributed to weeds smothering native plantings and water inundation of plots, and less commonly attributed to herbivory of plants by hares, and sun/wind exposure. Therefore I recommend that weed control, specifically herbicide application, continues at the site twice a year until the plantings outgrow invasive weed/grass species. Plant mortality from weed smothering was commonly observed during this study with some plants fully covered by weeds. I also recommend caution when selecting sites to plant $C$. australis (cabbage tree), O. virgata (bush daisy), P. totara (totara), C. robusta (karamu), L. scoparium (manuka) and $P$. tenuifolium (kohukohu), as higher water levels have proven detrimental to their survival and growth. It is, however, appropriate to plant $D$. dacridioides (kahikatea) in sites at Wairio Wetland that are inundated with water year-round as its survival was promoted by greater water cover in this study, but with associated reductions in growth. In addition, cabbage trees were commonly eaten by herbivores at the site, most likely hares or rabbits, which reduced their growth and survival. I recommend that monitoring of these species at the site is undertaken to assess their abundance at Wairio Wetland. Monitoring can include the use of chew cards, tracking tunnels, scat identification or sightings (King 2005; Sinclair 2012). While monitoring is undertaken I also recommend the erection of tree guards around cabbage tree plantings to act as a barrier method until population numbers are known and 
pest control methods such as poisoning, trapping, den fumigation, or night shooting can be undertaken (Eason \& Wickstrom, 2001, Otago Regional Council 2012; Spurr 1999). Native wetland plants not used in this particular study could also be tested at the site e.g. Phormium tenax (harakeke), Austroderia toetoe (toetoe) and Typha orientalis (raupo).

The planting experiment in Stage 3 found that excavating topsoil, the use of weedmats, and the planting of nurse trees at $1.5 \mathrm{~m}$ spacing promoted the highest survival of native woody vegetation planted at Wairio Wetland. In contrast, intact topsoil promoted greater growth of vegetation planted at Wairio. The success of these management techniques varied greatly between species. Recommendations for plant establishment on a species-specific basis are suggested in Table 30. It is also important to consider the cost of various management treatments when undertaking planting in restoration efforts. Most restoration efforts are constrained by limited funding and resources therefore the most cost-effective option can be highly regarded. The most cost-effective management treatment in this planting experiment involved the least effort of all treatment combinations, with intact topsoil, no nurse trees or weedmats and $1.5 \mathrm{~m}$ spacing at an average cost of $\$ 8.82$ per surviving tree and $42 \%$ plant survival. The least cost-effective management treatment combination was topsoil excavation, planting of nurse trees at $1.5 \mathrm{~m}$ spacing, and weedmats, at an average cost of $\$ 26.43$ per surviving tree, and was linked to greater average plant survival at 58\%. Therefore further restoration efforts at Wairio Wetland need to weigh up whether greater plant survival or the most cost-effective management option is desired.

The study has addressed issues surrounding revegetation efforts with guidance for future planting at the site, but has not been able to ascertain the effects eutrophication may have on the plant community at the site. Complete restoration of Wairio Wetland will not only require successful revegetation, but also reconstruction of hydrology, native fauna reintroduction, and pest and weed control to become a fully functioning, self-sustaining ecosystem. There is the potential for Wairio Wetland to be an international wetland of importance (RAMSAR site) in the future when the site is fully restored and to be linked to existing remnants of natural wetland ecosystems in the wider area. 
Table 30 Summary of management techniques proposed to promote plant establishment for each species at Wairio Wetland. Management treatments suggested below promoted the growth and/or survival of select species in the planting experiment. Some species not accustomed to winter flooding should be planted in higher areas that don't get waterlogged.

\begin{tabular}{|c|c|}
\hline Species & Management techniques \\
\hline C. australis & $\begin{array}{ll}\text { - } & \text { Intact topsoil } \\
\text { - } & \text { Nurse tree planting } \\
\text { - } & \text { Protection from herbivory } \\
& \text { (e.g. plant protectors, repellents) }\end{array}$ \\
\hline D. dacridioides & $\begin{array}{ll}\text { - } & \text { Intact topsoil } \\
\text { - } & \text { Herbicide spot-spraying, no weedmats } \\
\text { - } & \text { Nurse tree planting } \\
\text { - } & \text { Moderate - high water levels }\end{array}$ \\
\hline O. virgata & $\begin{array}{ll}\text { - } & \text { Excavated topsoil } \\
\text { - } & \text { Weedmat use } \\
\text { - } & \text { Minimal winter flooding }\end{array}$ \\
\hline P. totara & - Minimal winter flooding \\
\hline C. robusta & $\begin{array}{ll}\text { - } & \text { Intact topsoil } \\
\text { - } & \text { Minimal winter flooding }\end{array}$ \\
\hline C. propinqua & $\begin{array}{ll}\text { - } & \text { Intact topsoil } \\
\text { - } & 1.5 \mathrm{~m} \text { spacing }\end{array}$ \\
\hline P. tenuifolium & $\begin{array}{ll}\text { - } & \text { Excavated topsoil } \\
\text { - } & 1.5 \mathrm{~m} \text { spacing } \\
\text { - } & \text { Minimal winter flooding }\end{array}$ \\
\hline L. scoparium & $\begin{array}{l}\text { - } \text { Excavated topsoil } \\
\text { - } \text { Weedmat use } \\
\text { - } 1.5 \mathrm{~m} \text { spacing } \\
\text { - } \text { Minimal winter flooding }\end{array}$ \\
\hline
\end{tabular}




\subsection{References}

Booth EG, Loheide SP 2010. Effects of evapotranspiration partitioning, plant water stress response and topsoil removal on the soil moisture regime of a floodplain wetland: implications for restoration. Hydrological Processes 24: 2934-2946.

Buisson E, Holl KD, Anderson S, Corcket E, Hayes GF, Torre F, Peteers A, Dutoit T 2006. Effect of Seed Source, Topsoil Removal, and Plant Neighbor Removal on Restoring California Coastal Prairies. Restoration Ecology 14(4): 569-577.

Castro J, Zamora R, Hódar JA, Gómez JM 2002. Use of Shrubs as Nurse Plants: A New Technique for Reforestation in Mediterranean Mountains. Restoration Ecology 10(2): 297-305.

Ceulemans T, Merckx R, Hens M, Honnay O 2012. Plant species loss from European seminatural grasslands following nutrient enrichment - is it nitrogen or is it phosphorus?. Global Ecology and Biogeography 22: 73-82.

Eason CT, Wickstrom M ed. 2001. Vertebrate pesticide toxicology manual (poisons): Information on poisons used in New Zealand as vertebrate pesticides. Wellington, Department of Conservation. $120 \mathrm{p}$.

Gómez-Aparicio L, Gómez JM, Zamora R, Boettinger JL 2005. Canopy vs. soil effects of shrubs facilitating tree seedlings in Mediterranean montane ecosystems. Journal of Vegetation Science 16(2): 191-198.

Gough L, Osenberg CW, Gross KL, Collins SL 2000. Fertilization effects on species density and primary productivity in herbaceous plant communities. Oikos 89: 428-439.

Harpole WS, Tilman D 2007. Grassland species loss resulting from reduced niche dimension. Nature 446: 791-793. 
Harrington KC, Bedford TA 2004. Control of weeds by paper mulch in vegetable and trees. New Zealand Plant Protection 57: 37-40.

Hausman CE, Fraser LH, Kershner MW, de Szalay FA 2007. Plant community establishment in a restored wetland: Effects of soil removal. Applied Vegetation Science 10: 383-390.

Hölzel N, Otte A 2003. Restoration of a species-rich flood meadow by topsoil removal and diaspore transfer with plant material. Applied Vegetation Science 6: 131-140.

Iverson CM, Bridgham SD, Kellogg LE 2010. Scaling plant nitrogen use and uptake efficiencies in response to nutrient addition in peatlands. Ecology 91(3): 693-707.

King CM 2005. The Handbook of New Zealand Mammals 2ed. London, Oxford University Press. $600 \mathrm{p}$.

Klimkowska A, Kotowski W, van Diggelen R, Grootjans AP, Dzierża P, Brzezińska K 2010b. Vegetation Re-development After Fen Meadow Restoration by Topsoil Removal and Hay Transfer. Restoration Ecology 18(6): 924-933.

Leyshon AJ 1991. Effect of rate of nitrogen fertilizer on the above- and below-ground biomass of irrigated bromegrass in southwest Saskatchewan. Canadian Journal of Plant Science 71: 1057-1067.

López-Bucio J, Cruz-Ramírez A, Herrera-Estrella L 2003. The role of nutrient availability in regulating root architecture. Current Opinions in Plant Biology 6(3): 280-287.

Marcar NE, Hossain AKMA, Crawford DF, Nicholson AT 2000. Evaluation of tree establishment treatments on saline seeps near Wellington and Young in New South Wales. Australian Journal of Experimental Agriculture 40: 99-106. 
McDowell N, Pockman WT, Allen CD, Breshears DD, Cobb N, Kolb T, Plaut J, Sperry J, West A, Williams DG, Yepez EA 2008. Mechanisms of plant survival and mortality during drought: why do some plants survive while others succumb to drought?. New Phytologist 178(4): 719-739.

Ogle M 1996. Factors affecting the early growth and survival of indigenous seedlings planted for the purpose of ecological restoration. Christchurch, University of Canterbury. 108 p.

Otago Regional Council 2012. A guide to rules and methods for rabbit control in Otago. Dunedin, Otago Regional Council. Retrieved 5 October 2012, from http://www.orc.govt.nz/Documents/Content/Information\%20Services/Pests/Rabbit s/ORC\%20RABBIT\%20LEAFLET\%20WEB.pdf.

Pekin BK, Boer MM, Wittkuhn RS, Macfarlane C, Grierson PF 2012. Plant diversity is linked to nutrient limitation of dominant species in a world biodiversity hotspot. Journal of Vegetation Science 23(4): 745-754.

Sinclair A 2012. Draft protocol - Chew Cards for Landcare groups. Whakaupoko, Landcare Research. Retrieved 8 September 2012, from http://www.patumahoe.org.nz/enviro nment-nature/draft-protocol/.

Spurr EB 1999. Toxicants for control of stoats (Mustela erminea). Conservation Advisory Science Notes No. 261. Wellington, Department of Conservation. 8 p.

Stange EE, Shea KL 1998. Effects of deer browsing, fabric mats, and tree shelters on Quercus rubra seedlings. Restoration Ecology 6: 29-34.

Stevens CJ, Thompson K, Grime JP, Long CJ, Gowing DJG 2010. Contribution of acidification and eutrophication to declines in species richness of calcifuge grasslands along a gradient of atmospheric nitrogen deposition. Functional Ecology 24: 478-484. 
Tyler AC, Lambrinos JG, Grosholz ED 2007. Nitrogen inputs promote the spread of an invasive marsh grass. Ecological Applications 17(7): 1886-1898.

Woodward CL 1996. Soil compaction and topsoil removal effects on soil properties and seedling growth in Amazonian Ecuador. Forest Ecology and Management 82:197-209. 


\section{Appendix 4.4}

\section{Appendix 4.4.1 Photos from Wairio Wetland}

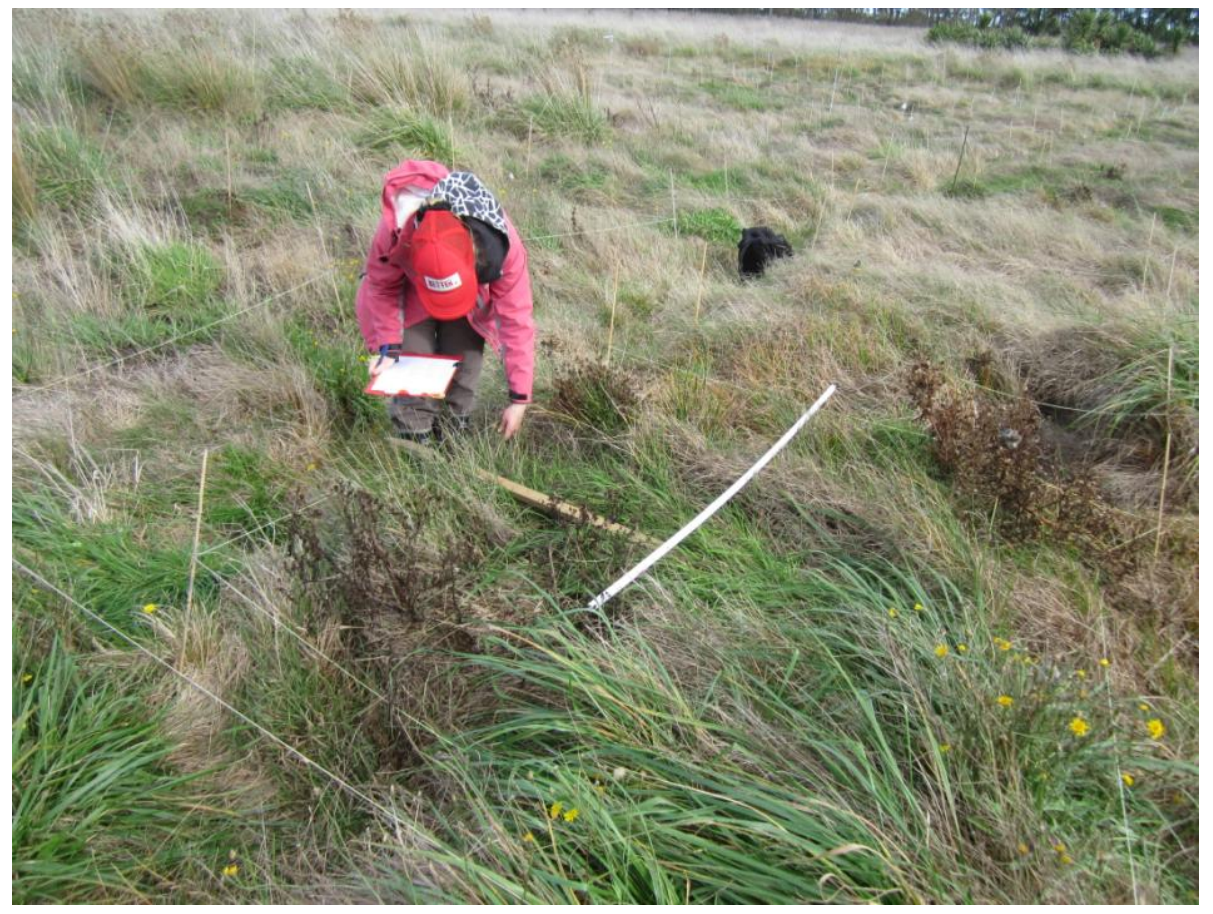

Figure 41 The author at Wairio Wetland, Stage 2, recording plant composition in quadrats. Photo by Patrick Gillon, January 2013.

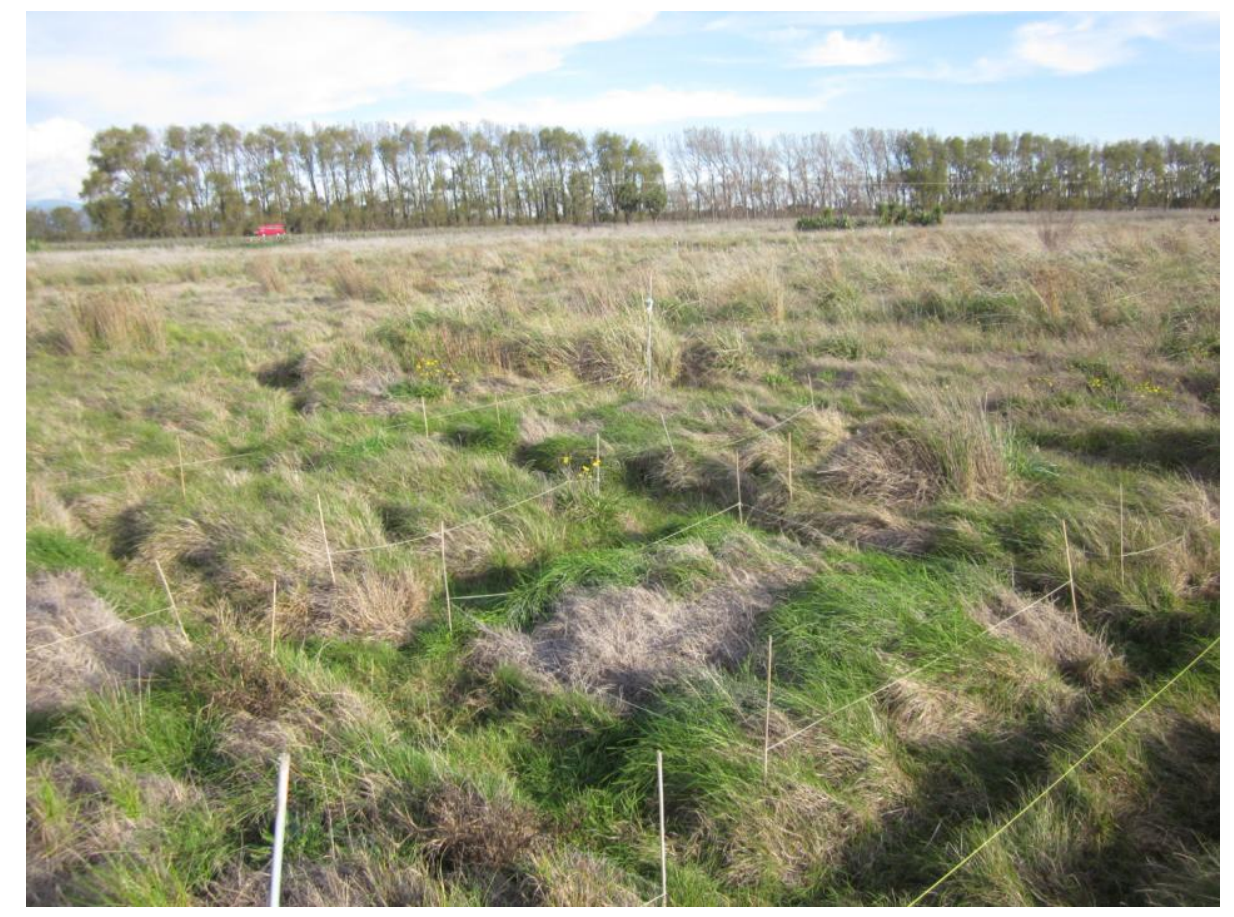

Figure 42 Wairio Wetland, Stage 2, Block 3. Block and plot boundaries outlined with bamboo sticks and builders wire. Photo by Dr Stephen Hartley, April 2013. 


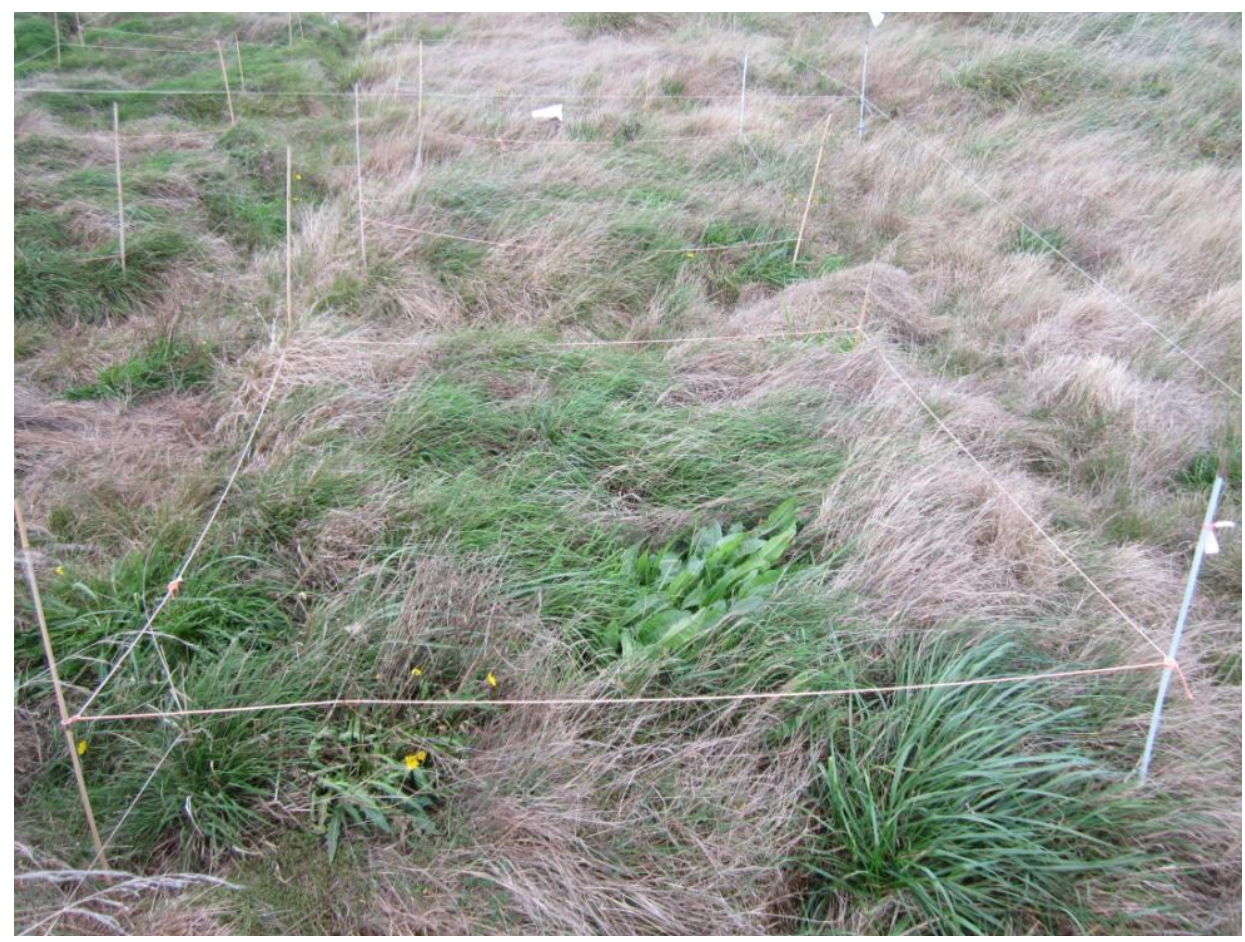

Figure 43 Wairio Wetland, Stage 2, percent cover of vegetation in Block 3, Plot 1D. Photo by author, January 2013.

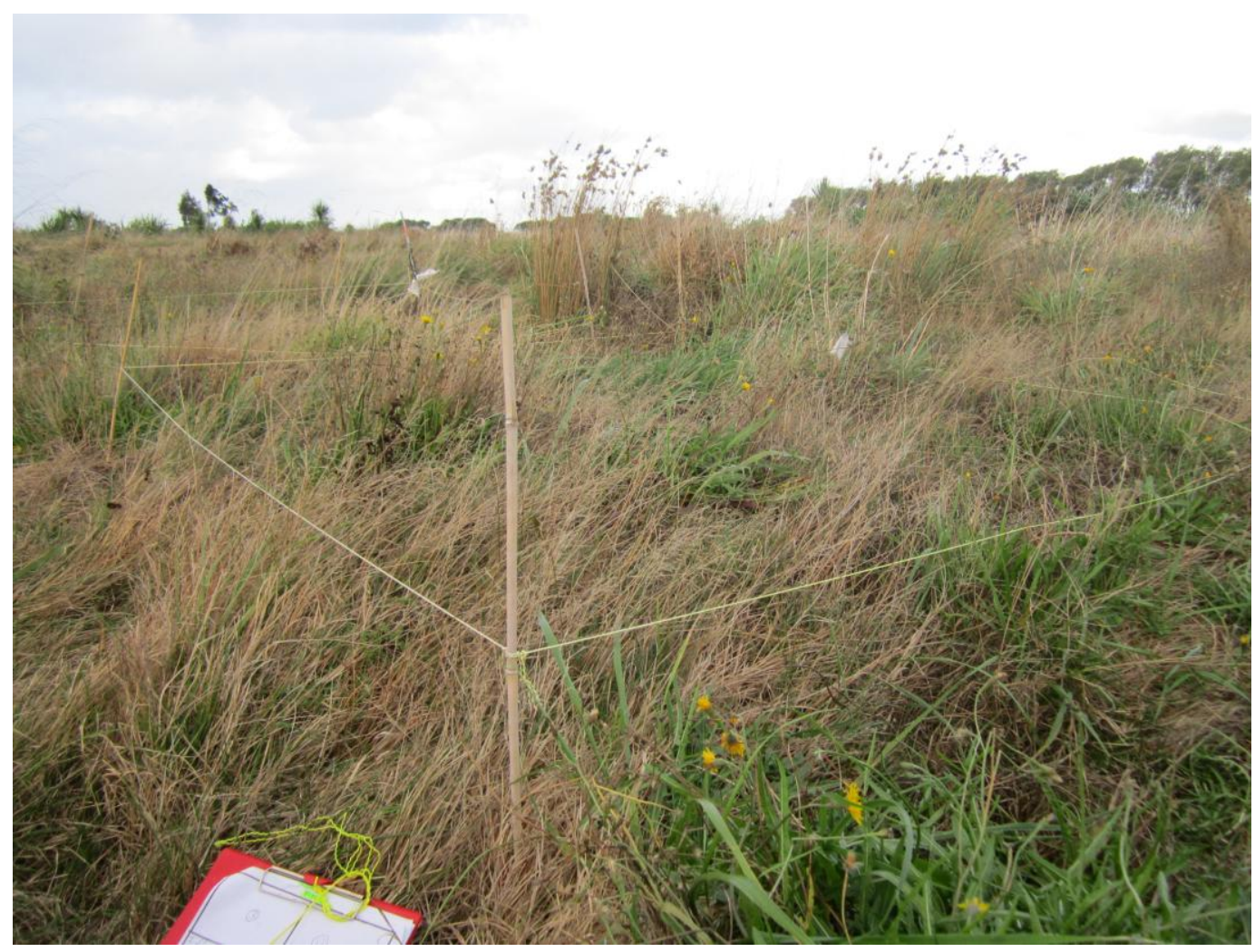

Figure 44 Wairio Wetland, Stage 2, Height profile of vegetation in Block 3, Plot 1B. Photo by author, January 2013. 


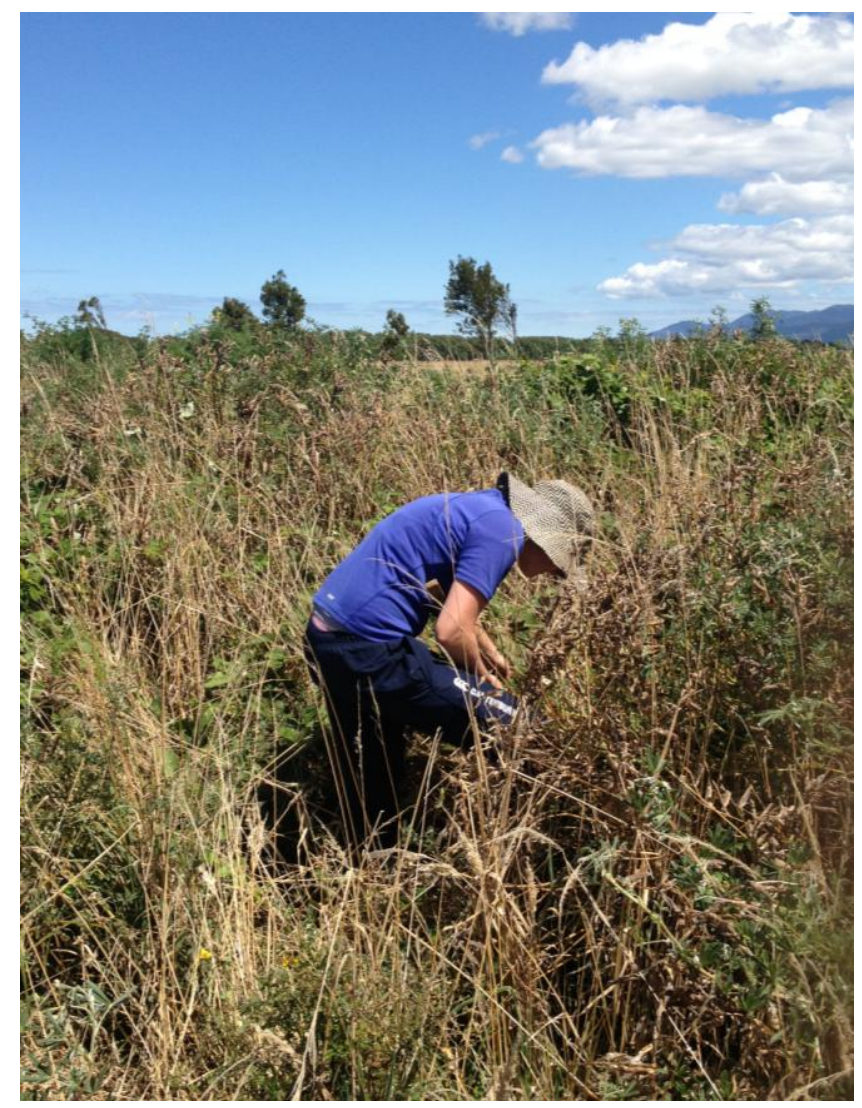

Figure 45 The author at Wairio Wetland, Stage 3, recording the survival of trees in a block with abundant weeds. Photo by Patrick Gillon, January 2013.

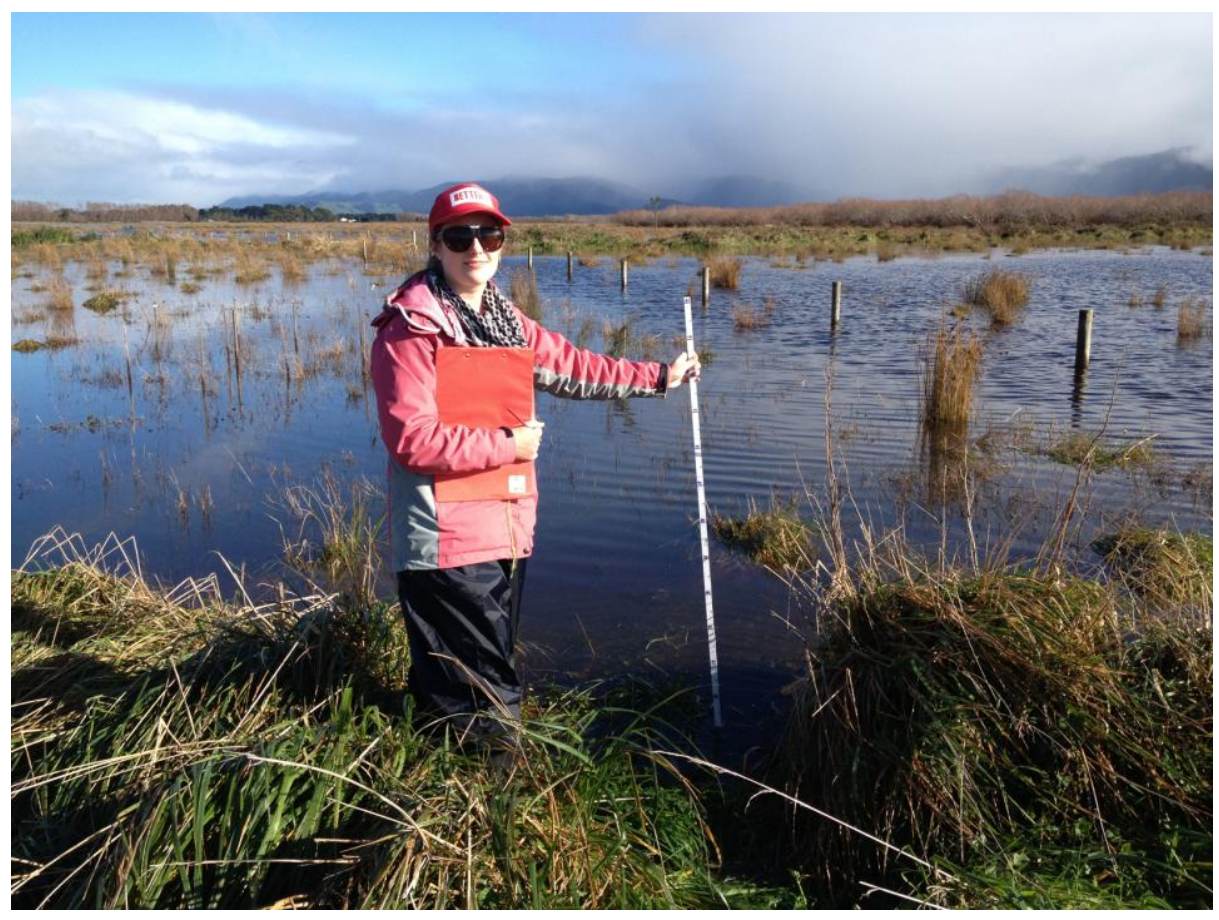

Figure 46 The author at Wairio Wetland, Stage 3, measuring the height of trees in the waterlogged blocks at the site. Photo by Patrick Gillon, June 2013. 


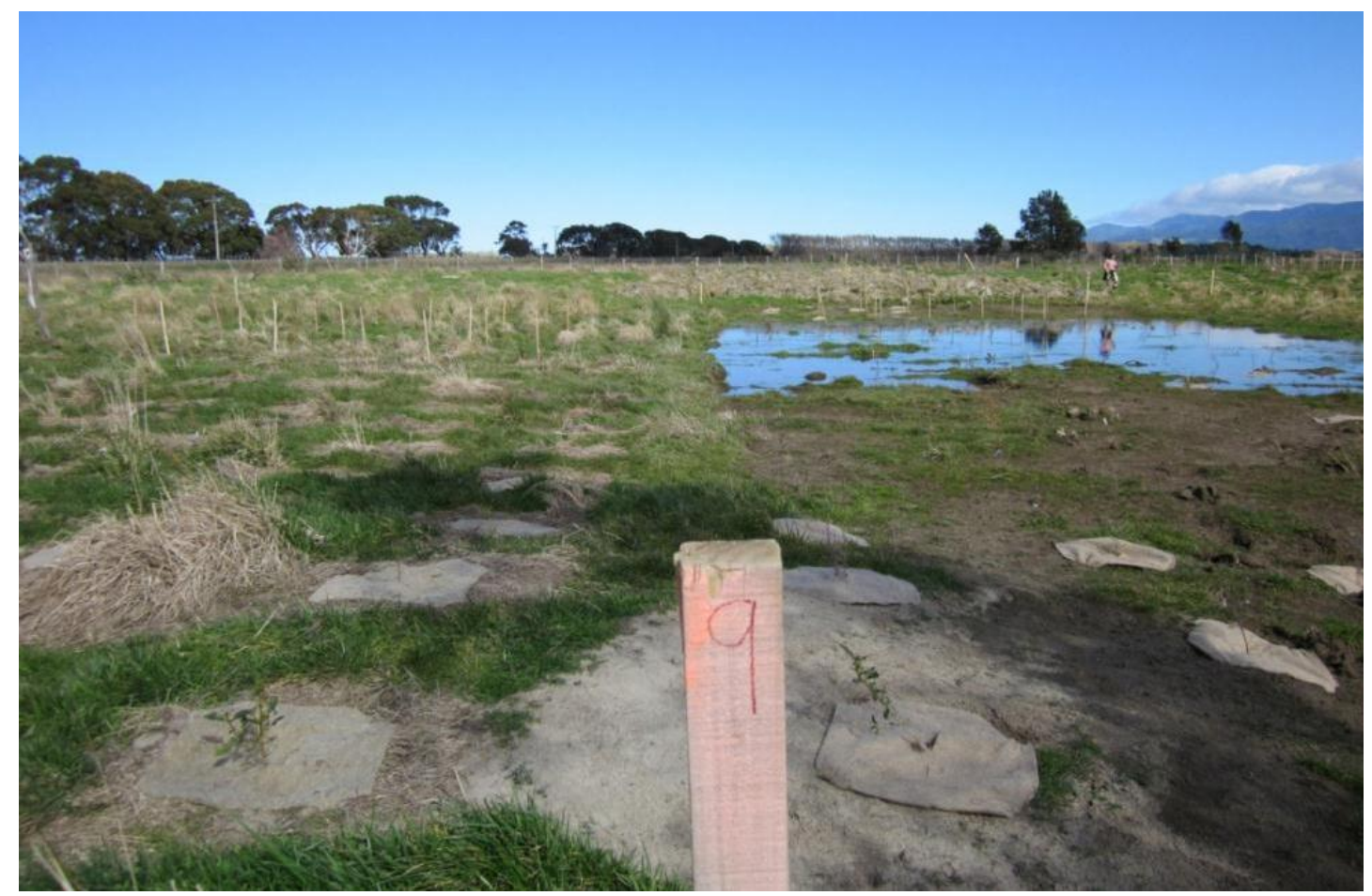

Figure 47 Stage 3 at Wairio Wetland, Block 9 with newly planted saplings in June 2011. Lefthand side topsoil intact. Right-hand side topsoil excavated with waterlogging present. Weedmats and herbicide spot spraying evident. Photo by Dr Stephen Hartley.

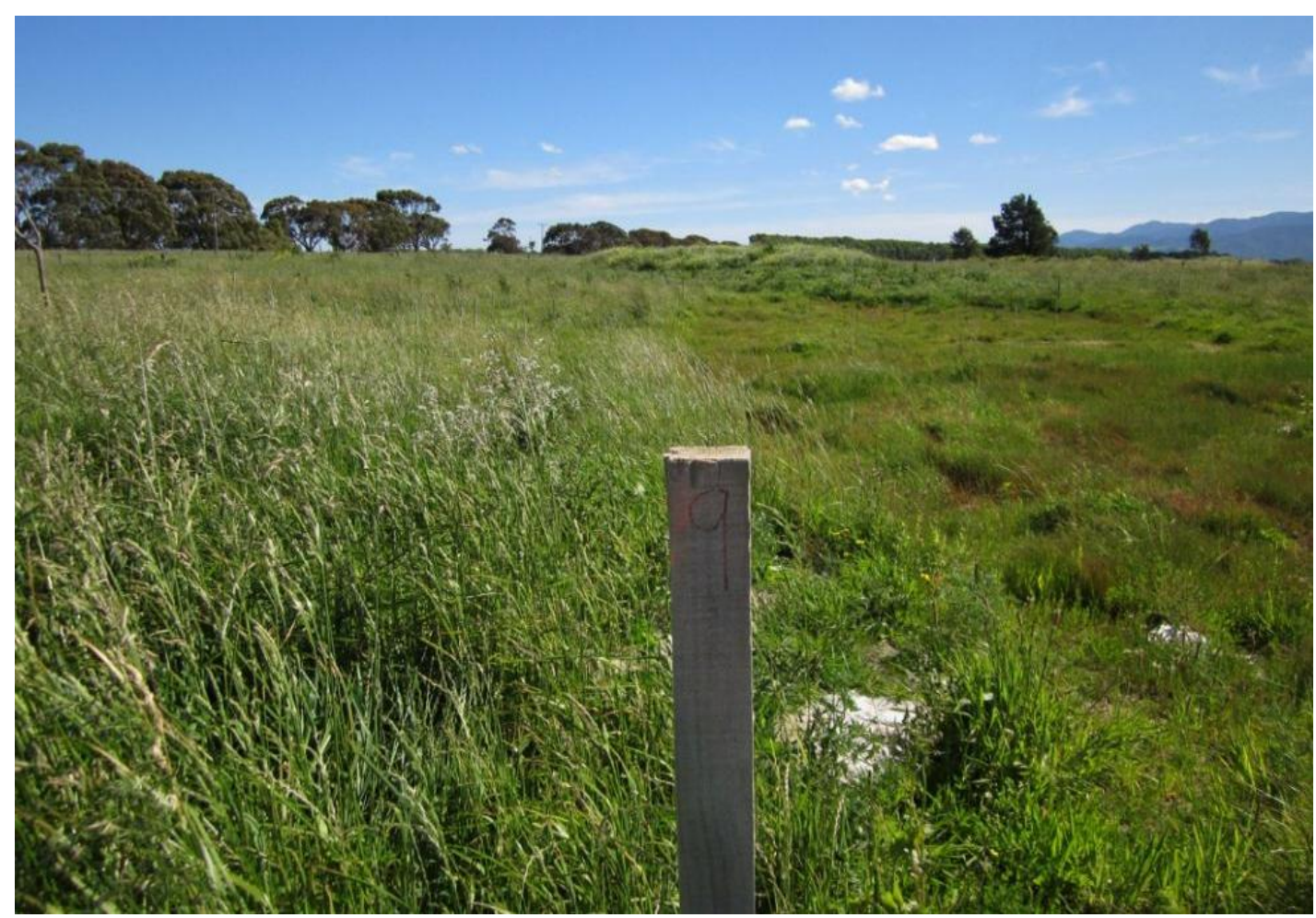

Figure 48 Stage 3 at Wairio Wetland, Block 9 in December 2011. Left-hand side topsoil intact with high vegetation e.g. tall fescue. Right-hand side topsoil excavated with shorter sedges. Photo by Dr Stephen Hartley. 


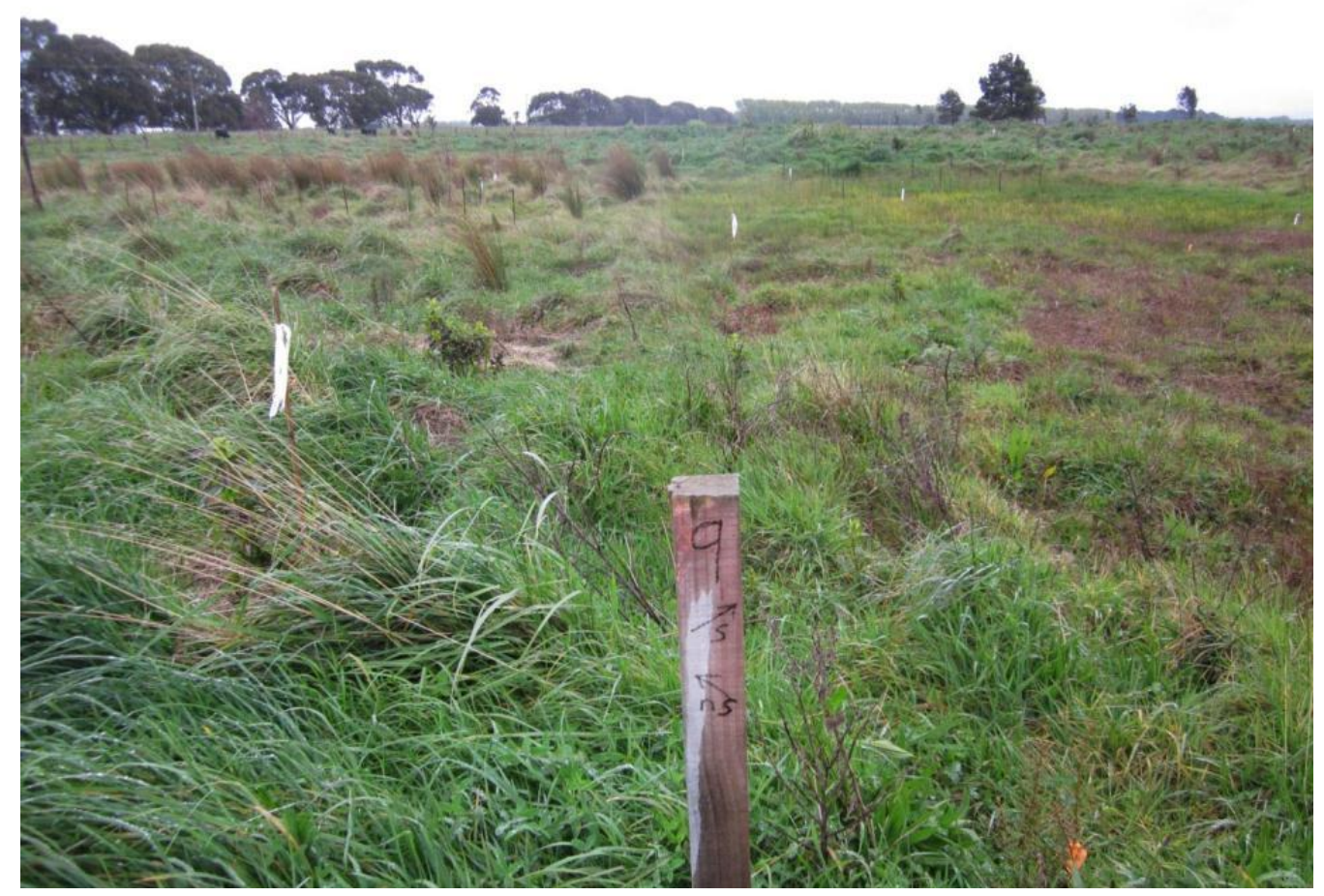

Figure 49 Stage 3 at Wairio Wetland, Block 9 in September 2012. Left-hand side topsoil intact with saplings visible. Right-hand side topsoil excavated with shorter vegetation. Photo by Dr Stephen Hartley.

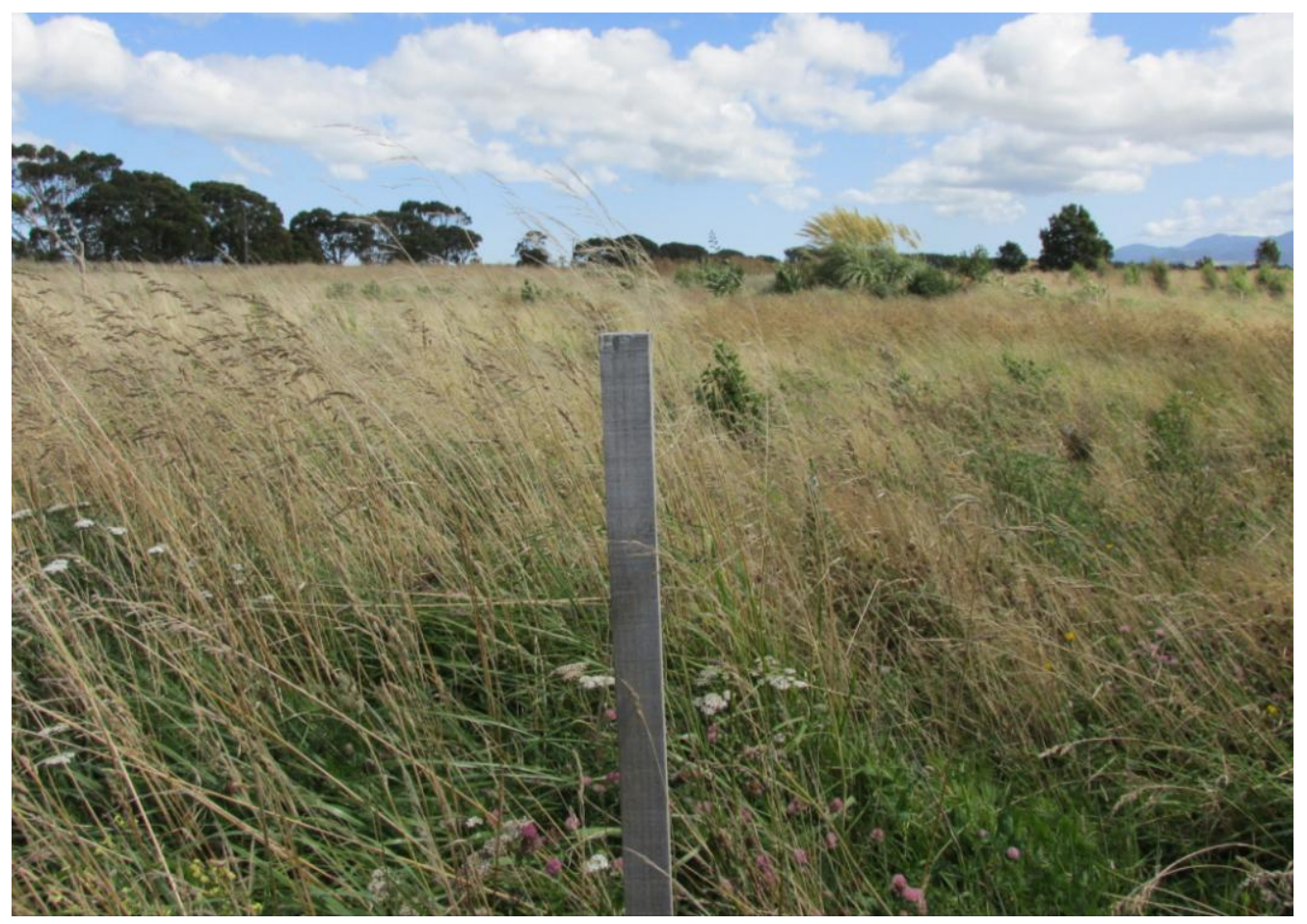

Figure 50 Stage 3 at Wairio Wetland, Block 9 in February 2014. Left-hand side topsoil intact, right-hand side topsoil excavated, both with tall vegetation. Photo by author. 